UNIVERSIDADE DE SÃO PAULO

FACULDADE DE FILOSOFIA, LETRAS E CIÊNCIAS HUMANAS

DEPARTAMENTO DE HISTÓRIA

PROGRAMA DE PÓS-GRADUAÇÃO EM HISTÓRIA SOCIAL

\title{
Ventura e Desventura no Rio Ribeira de Iguape
}

Versão Corrigida

Gabriela Segarra Martins Paes

São Paulo

2014 
UNIVERSIDADE DE SÃO PAULO

FACULDADE DE FILOSOFIA, LETRAS E CIÊNCIAS HUMANAS

DEPARTAMENTO DE HISTÓRIA

PROGRAMA DE PÓS-GRADUAÇÃO EM HISTÓRIA SOCIAL

\section{Ventura e Desventura no Rio Ribeira de lguape}

(versão corrigida - exemplar original encontra-se disponível no CAPH da FFLCH)

Gabriela Segarra Martins Paes

Tese apresentada para obtenção do título de doutor pelo Programa de Pós-Graduação em História Social, do Departamento de História da Faculdade de Filosofia, Letras e Ciências Humanas da Universidade de São Paulo.

Orientadora: Profa. Dra. Marina de Mello e Souza

São Paulo

2014 
UNIVERSIDADE DE SÃO PAULO

FACULDADE DE FILOSOFIA, LETRAS E CIENNCIAS HUMANAS

DEPARTAMENTO DE HISTÓRIA

PROGRAMA DE PÓS-GRADUAÇÃO EM HISTÓRIA SOCIAL

\section{Ventura e Desventura no Rio Ribeira de Iguape}

(versão corrigida - exemplar original encontra-se disponível no CAPH da FFLCH)

Gabriela Segarra Martins Paes

Tese apresentada para obtenção do título de doutor pelo Programa de Pós-Graduação em História Social, do Departamento de História da Faculdade de Filosofia, Letras e Ciências Humanas da Universidade de São Paulo.

Orientadora: Profa. Dra. Marina de Mello e Souza

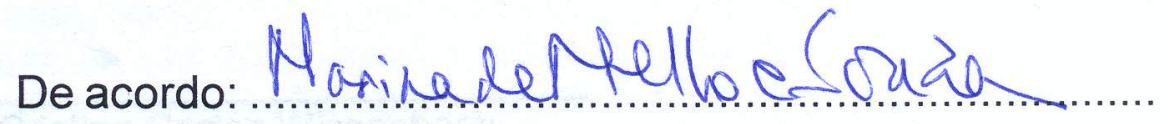

Profa. Dra. Marina de Mello e Souza

São Paulo 


\section{Folha de Aprovação}

Gabriela Segarra Martins Paes

Ventura e Desventura no Rio Ribeira de Iguape

Tese apresentada para obtenção do título de doutor pelo Programa de PósGraduação em História Social, do Departamento de História da Faculdade de Filosofia, Letras e Ciências Humanas da Universidade de São Paulo.

Data da Aprovação: 06/03/2014

Banca Examinadora:

Profa. Dra. Fabiana Schleumer

Profa. Dra Lucilene Reginaldo

Profa. Dra Maria Cristina Cortez Wissenbach

$\overline{\text { Profa. Dra Maria Helena Pereira Toledo Machado }}$

$\overline{\text { Profa. Dra Marina de Mello e Souza (Orientadora) }}$ 


\section{Agradecimentos}

Agradeço a todas as pessoas que me acompanharam neste percurso.

À Profa. Dra. Marina de Mello e Souza, pela confiança no tema da pesquisa e no meu trabalho, pela sinceridade e pela compreensão. É um orgulho tê-la como orientadora.

A minha mãe Maria Nazaré Martins Paes, ao meu pai Francisco Segarra Martins Paes, aos meus irmãos Mauro e Cynara.

À Profa. Dra. Maria Cristina Wissenbach, pelas importantes sugestões durante a qualificação e a defesa, pela contribuição em vários momentos da pesquisa, pelo incentivo e pela companhia, não só na USP, mas também no Vale do Ribeira.

Às Profas. Dras. Profas. Dras. Fabiana Schleumer, Lucilene Reginaldo e Maria Helena Pereira Toledo Machado, pelas valiosas recomendações dadas no momento da defesa.

Ao Prof. Dr. Renato da Silva Queiroz, pela relevante contribuição durante a qualificação.

Aos professores e colegas da pós-graduação, especialmente aos participantes da linha de pesquisa "Escravidão e História Atlântica" e do grupo NAP (Núcleo de Apoio à Pesquisa Brasil África).

A Gisele Novaes Friguetto, pela leitura cuidadosa.

À Fundação ITESP. Agradeço por ter sido incluída no Programa de Incentivo ao Aprimoramento Profissional. Agradeço à banca do citado programa, especialmente a Márcia Andrade, Antonieta Fiori e Isaías Santana.

Aos meus colegas da Fundação ITESP, especialmente os funcionários do escritório de Eldorado e da Gerência de Desenvolvimento Humano. Agradeço aos meus colegas Walter Hatakeyama, Regianne Ferreira Nascimento, Heline Elias Castro, Sergio Fabrício Bom Joanni, Maria Ignez Maricondi, João dos Anjos Leonel, Regina Célia Arruda Bonomo, Maria das Dores Teixeira Fonseca, Tiago Marques de Oliveira e Ana Paula Vianna.

À antropóloga da Fundação ITESP, Patrícia Scalli Santos, pelas valiosas informações e por todas as discussões sobre o Vale do Ribeira.

À Casa Paroquial de Eldorado, especialmente ao padre Ari e às irmãs Ângela Biagioni e Sueli Berlanga.

À Cúria Metropolitana de São Paulo, ao Museu Paulista e ao Arquivo do Estado de São Paulo. 
À Casa Paroquial de Iguape, especialmente ao padre Jaime Marcelo Maria Gato e à Silvia Naira Monteiro Trigo.

Aos iguapenses Marcos do Prado, Carlos A. Pereira Júnior, Robertos Fortes e Valmir Mariano.

Aos meus amigos e familiares, especialmente Paula Figueiredo Bischoff, Alice Satie Yamamoto, Eliana Harumi Uemura, Tatiana Sanchez, Juliana Santos, Sônia Mara Pereira, Carolina Tejero, Sérgio, Joaquim, Matheus Pranskvicius, Manuela Martins, Flavia Machado Heitmann Machado Peixoto, Roger Frugoli Peixoto, Lais Heitmann M. F. Peixoto, Cássio Heitmann M. F. Peixoto, Carolina Martins Oliveira, Celso Costa, João Victor Costa, Gustavo Costa, Tomás Costa, Leopoldina Martins, Frederico Oliveira, André Oliveira, Karina Bibiano e Cristiane Bibiano.

Aos quilombolas Antonio Benedito Jorge, Cacilda de Ramos Dias, Adão Rolim Dias, Bertolino Silvério, Maria Rita Silvério, Leide Maria de Miranda Jorge, Edvina Maria Tié, Pedro Pereira, Laura Furquim, Antonia Gonçalves de Pontes, Maria das Dores Jorge Cravo, Bonifácio Modesto Pereira, Santina Batista dos Santos, Elvira Morato, Irene Mandira Coutinho, Pedro Peniche, José Cosme, Sílvia, Esperança Santana Rosa, João Rosa, Pedro Pereira, Jandira Cunha, Benedito Alves da Silva, Aristides Furquim, Leonila da Costa Pontes, Carmo Jorge de Moraes, Iracema, Gica, Orácia, Bartolomeu, Anísia, Jovita Furquim, Edu Nolasco, Santina Batista dos Santos, Aparício dos Santos e Zulmira Rosa Oliveira, pela ajuda.

A todos os quilombolas das comunidades de Sapatu, Pedro Cubas, Pedro Cubas de Cima, André Lopes, Nhunguara, Ivaporunduva, Pilões, Maria Rosa, São Pedro, Galvão, Praia Grande, Bombas, Porto Velho, Cangume, Abobral, Morro Seco e Mandira. 
"O rio, esse caminho de canções, de esperanças, de trocas, de naufrágios"

Carlos Drummond de Andrade 


\section{Resumo}

Esta pesquisa aborda a importância das águas do Rio Ribeira de Iguape para a história do Vale do Ribeira. As águas desse rio foram exploradas desde o início da colonização. No século XVI, partiam expedições em busca de metais preciosos na sua foz. Nos dois séculos seguintes, as águas do Rio Ribeira continuaram a ser exploradas e metais preciosos foram descobertos no Alto e no Médio Vale, onde foram estabelecidos arraiais mineradores. No final do século XVIII, a mineração entrou em decadência, e o arroz passou a ser cultivado em escala comercial. A lavoura acompanhava o leito do Rio Ribeira e dos seus afluentes, já que águas do rio garantiam a fertilidade dos solos, energia para mover engenhos d'água e local de atraque para as canoas. Entre os séculos XVII e XIX, muitos africanos aportaram na região para o trabalho nas minas e nas lavouras. Africanos e europeus inscreveram, nas águas do Rio Ribeira, seus mitos e crenças, dentre os quais destacaremos os negros d'água. Também, nas mesmas águas, foi lavada a Imagem do Senhor Bom Jesus de Iguape, o santo mais festejado do Vale do Ribeira. O Rio Ribeira também era utilizado em ritos de adivinhação e cura. Neste trabalho, os mitos e as crenças foram analisados dentro da perspectiva atlântica, ou seja, entendendo as formações culturais criadas em solo americano como elaboradas a partir do encontro de povos diversos, postos em contato sob o escravismo e possuidores de diferentes visões de mundo. Abordamos a evangelização ocorrida na África Central e no Vale do Ribeira e destacamos que, nos dois lados do Atlântico, o catolicismo foi reinterpretado segundo crenças locais. Analisamos a presença das crenças africanas no Vale do Ribeira, especialmente o culto aos mortos e os ritos de adivinhação e cura.

Palavras-chave: remanescente de quilombo. Vale do Ribeira. religiosidade afroamericana. cultura popular. catolicismo popular. 


\begin{abstract}
This research approaches the importance of the waters of Ribeira de Iguape River to the history of Ribeira Valley. This river has been exploited since the beginning of the colonization. In the sixteenth century, expeditions used to search for precious metals from river mouth. In the following centuries, the waters continued to be exploited and precious metals were discovered in the Upper and Middle Valley, where metal mines were established. In the late eighteenth century, mining went into decline and rice began to be cultivated on a commercial scale. The rice crop followed the bed of the Ribeira River and its tributaries, due to the fertility of soils, the energy devices to move water and the docking sites for canoes. Between the seventeenth and nineteenth centuries, many Africans landed in the region to work in mines and plantations. Africans and Europeans inscribed in the waters of Ribeira River their myths and beliefs, among them, we will highlight the water negro (negro d'água). Also, in the same waters it was washed the image of Lord Good Jesus of Iguape, the most celebrated saint of Ribeira Valley. The Ribeira river were also utilized for rites of divination and healing. Myths and beliefs were analyzed within the Atlantic perspective, understanding the cultural formations created on American soil as compiled from the meeting of diverse people, brought into contact under slavery and owners of different worldviews. We discussed the evangelization occurred in Central Africa and in Ribeira Valley, then we highlighted that, on both sides of the Atlantic, the catholicism was reinterpreted according to local beliefs. We also analyzed the presence of African beliefs in the Ribeira Valley, especially the cult of the dead and the rites of divination and healing.
\end{abstract}

Keywords: former quilombos. Ribeira Valley. african-american religiosity. popular culture. popular catholicism. 


\section{Índice de Figuras}

Mapa 1 - Rio Ribeira de Iguape................................................. 19

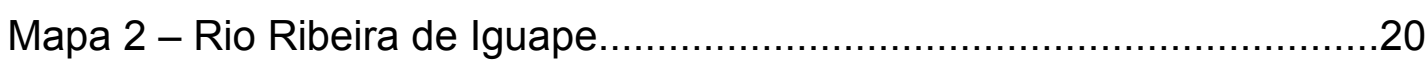

Mapa 3 - Com. Remanescentes de Quilombo de São Paulo.....................21

Mapa 4 - Propr. com escravizados e núcleos de libertos .........................65

Anexo 1 - Tabela - Situação das Comunidades de Quilombo de SP...... 255

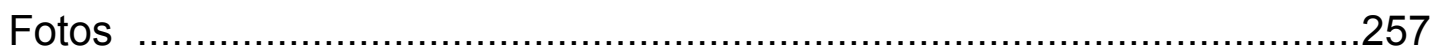




\section{Sumário}

INTRODUÇÃO

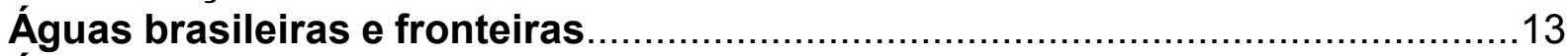

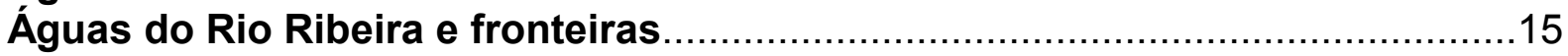

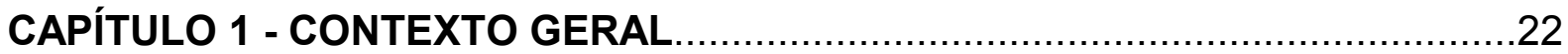

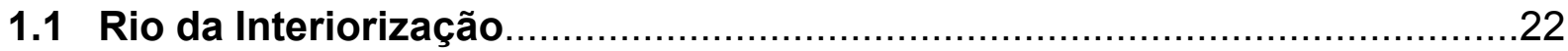

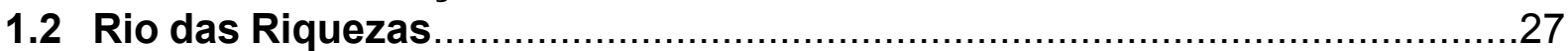

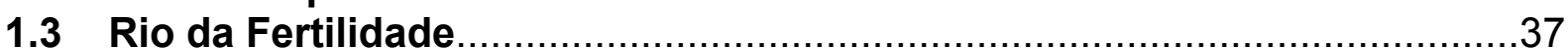

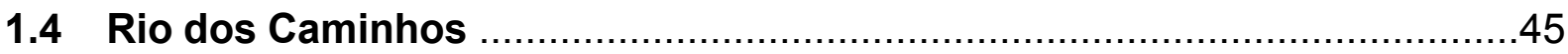

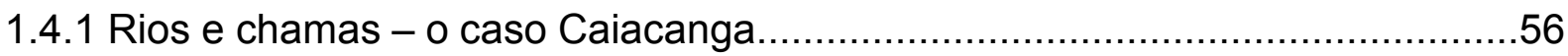

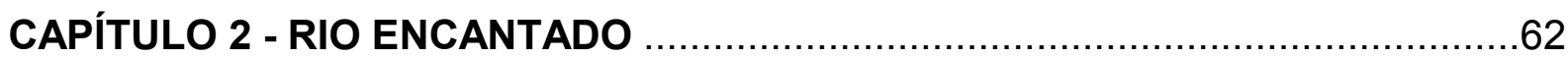

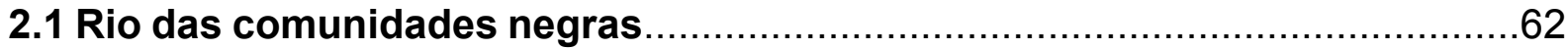

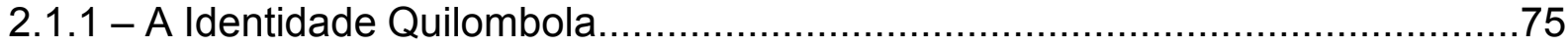

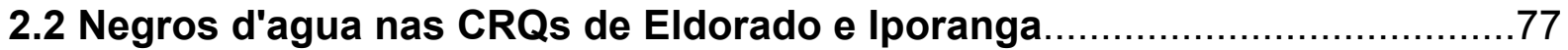

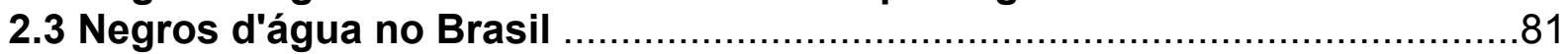

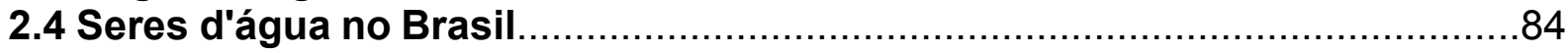

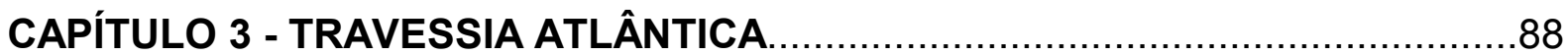

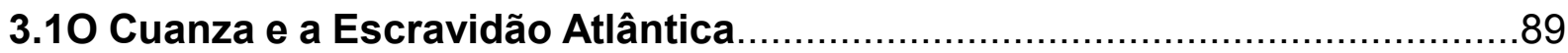

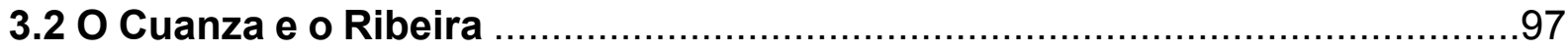

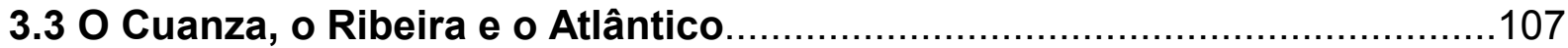

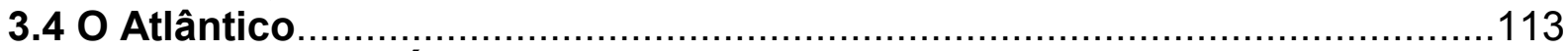

3.5 O Atlântico e as Águas Cristãs .........................................................116

CAPÍTULO 4 - ÁGUA E SAL - CATOLICISMO NA ÁFRICA CENTRO

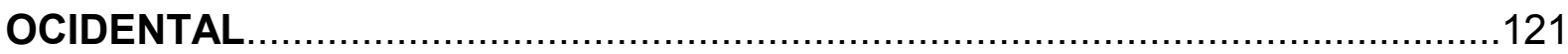

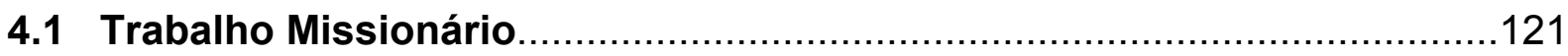

4.2 O Catolicismo e as populações africanas ...........................................130

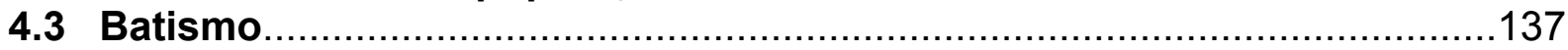

CAPÍTULO 5 - INSTITUCIONALIZAÇÃO DO CATOLICISMO NO VALE DO RIBEIRA

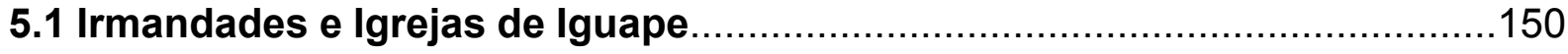

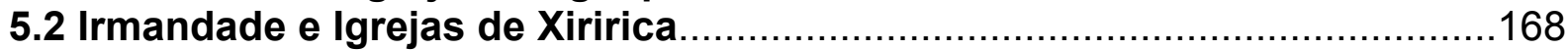

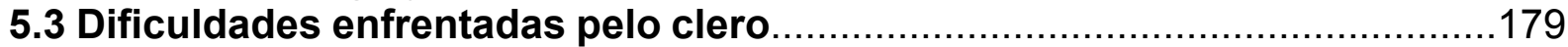

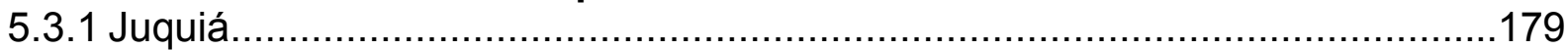

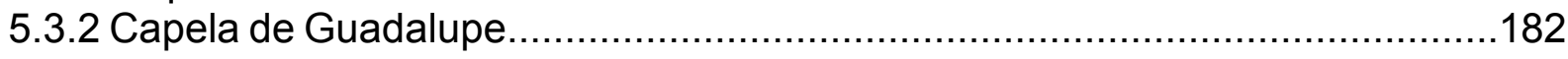


CAPÍTULO 6 - ÁGUAS E MORTOS

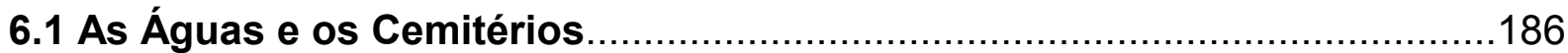

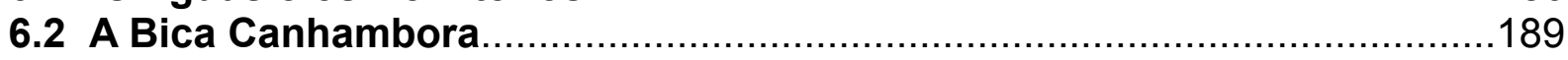

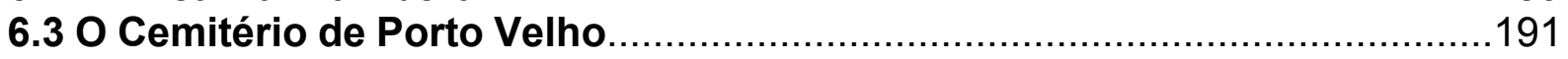

CAPÍTULO 7 - ÁGUAS E “CURADORES DE FEITIÇO” ................................197

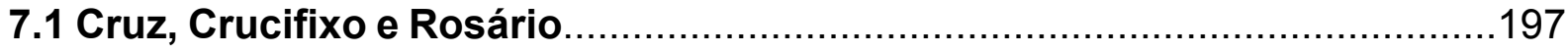

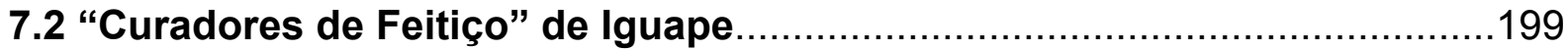

7.3 “Curandores" nas comunidades negras do Médio Ribeira .......................214

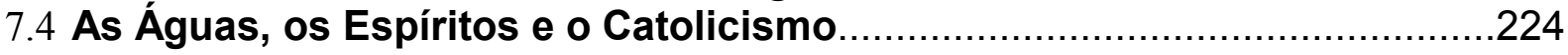

CAPÍTULO 8 - AS ÁGUAS - CIRCULARIDADE E FRONTEIRA NO MUNDO

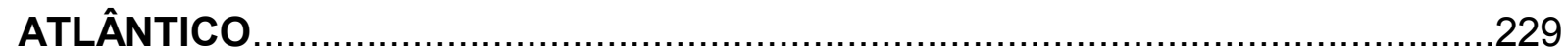

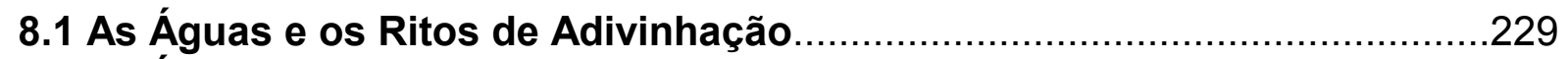

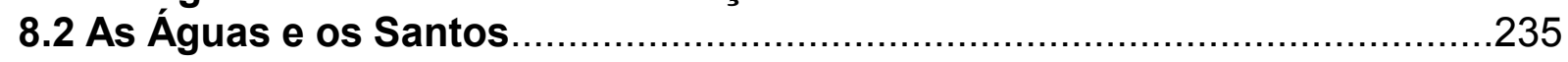

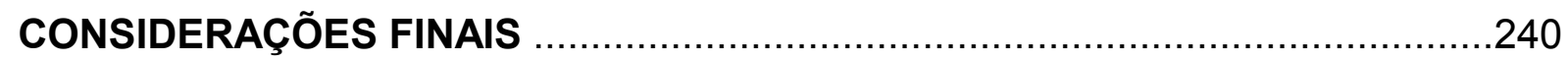

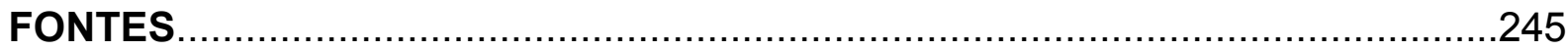

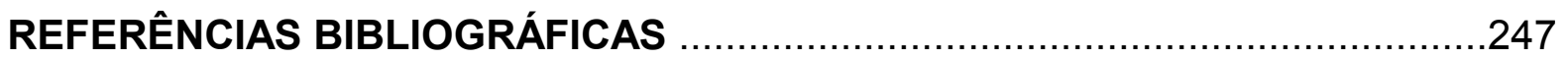

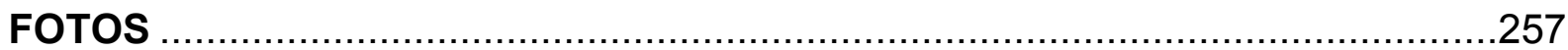




\section{Introdução}

Nenhum elemento é tão essencial à vida quanto a água. Os seres humanos são por ela constituídos - a água ${ }^{1}$ está presente em todos os processos fisiológicos e bioquímicos do corpo. Imprescindível para a conservação da vida, a história da humanidade está vinculada a este solvente universal. Atualmente, entre os muitos usos da água, podemos destacar sua utilização na agricultura, na indústria, nos cuidados de higiene e limpeza, no lazer, na eliminação de dejetos orgânicos e na geração de energia ${ }^{2}$.

Do total das águas do planeta, $97,5 \%$ são salgadas e apenas o restante, $2,5 \%$, é doce. O Brasil ocupa um importante papel no cenário mundial, pois detém $12 \%$ do total de água doce do mundo, sendo, por isso, considerado uma potência hídrica. A água pode tornar-se um bem valioso no futuro, pois as dificuldades de abastecimento evidenciam que a água potável é um bem finito e que o processo de degradação ambiental aponta para a sua vulnerabilidade. Entre os principais problemas ambientais relacionados com as águas, podemos citar a poluição dos oceanos, rios, lagos e mananciais e a falta de saneamento básico. Outro problema atual é o barramento do curso de um rio para a construção de usinas hidrelétricas e os subsequentes danos, tais como a submersão da flora e fauna e as alterações nos ciclos ecológicos.

Como o ser humano tem necessidade de dotar de sentido o mundo ao seu redor, a água, além de uma dimensão material, também tem uma dimensão simbólica. Como ressaltou Queiroz, "[...] a água encontra franco acolhimento no imaginário de todos os povos"3 ${ }^{3}$. Associada ao florescimento da vida, a água deu margem a um conjunto de simbologias e representações ${ }^{4}$. Símbolo de pureza e fertilidade, em muitas narrativas mítico-religiosas, a água representa uma dádiva

\footnotetext{
${ }^{1}$ Ao nascer, um bebê é constituído por mais de $70 \%$ de água. À medida que crescemos, essa porcentagem decresce gradualmente. Ainda assim, o organismo de um adulto é constituído por cerca de $60 \%$ de água.

${ }^{2}$ QUEIROZ, Renato da Silva. Caminhos que andam: os rios e a cultura brasileira. In: REBOUÇAS, Aldo da Cunha; BRAGA, Benedito; TUNDISI, José Galizia (Orgs.). Águas Doces no Brasil: Capital Ecológico, Uso e Conservação. 3 ed. São Paulo: Escrituras Editora, 2006, p. 719.

${ }^{3}$ QUEIROZ, op. cit., p. 721.

${ }^{4}$ Ibid., p. 720.
} 
primordial concedida às coletividades humanas ${ }^{5}$.

\section{Águas brasileiras e fronteiras}

As águas brasileiras despertaram a atenção dos portugueses desde que eles aqui chegaram. Em 1500, Pero Vaz de Caminha destacou que as "[...] Águas são muitas; infindas. E em tal maneira graciosa que, querendo-a aproveitar (a terra), darse-á nela tudo; por causa das águas que tem"6. Contudo, as águas não foram utilizadas apenas na lavoura. Elas estão associadas às fronteiras, tanto físicas quanto culturais.

Quanto às fronteiras físicas, as águas desempenharam função relevante em relação aos contornos do nosso território. No alargamento das fronteiras iniciais, delimitadas pelo Tratado de Tordesilhas, os rios tiveram papel de destaque.

Sérgio Buarque de Holanda, ao pesquisar as expedições bandeirantes do século XVII e as monções de povoamento do século XVIII, ressaltou a questão dos rios e das fronteiras. Destacou a mobilidade do povo paulista, o qual desbravou "[...] terras incultas, fundando capelas e povoados sertanejos e, sobretudo, dilatando no continente o mundo da língua portuguesa." ${ }^{7}$ Ou seja, os paulistas desempenharam papel fundamental para a expansão das fronteiras geográficas do território português. Nesse processo de interiorização, "fronteiras" técnicas e culturais foram rompidas. O português, para resistir à hostilidade do meio, desenraizou-se de suas tradições e assimilou os hábitos indígenas. Dessa forma, os paulistas, nascidos da miscigenação entre indígenas e portugueses, estavam muito mais próximos dos indígenas do que dos portugueses. Como exemplo do que os portugueses aprenderam com os indígenas, podemos citar as técnicas de lavoura, o reconhecimento dos animais que serviam para caça, a preparação dos remédios

\footnotetext{
${ }^{5}$ QUEIROZ, 2006, p. 721.

${ }^{6}$ CAMINHA, Pero Vaz. A Carta de Pero Vaz de Caminha. Rio de Janeiro: Livraria Agir Editora, 1965, p. 110.

"A presença de boas águas determinou muitas vezes a escolha de sítios para a instalação de povoados". (HOLANDA, Sérgio Buarque. Caminhos e Fronteiras. Rio de Janeiro: J Olympio: Prolivro, 1975, p. 45).
} 
naturais e a localização de boa água para beber. Conforme Holanda:

\begin{abstract}
Os verdadeiros meios de que dispunham, tanto índios como sertanistas, quando procuravam algum veio d'água em lugar onde nada indicava sua presença, escapam, todavia, a uma análise precisa e objetiva. Em regra, esses meios decorrem da extraordinária capacidade de observação da natureza, peculiar a esses homens e inatingível para o civilizado. ${ }^{8}$
\end{abstract}

Os indígenas também contribuíram com as trilhas terrestres. Abriram picadas, as quais, posteriormente, foram utilizadas pelos europeus. As trilhas terrestres eram percorridas, na grande maioria das vezes, a pé. No entanto, os rios tiveram um importante papel nesse processo de expansão pelo continente, pois ofereceram a orientação a ser seguida ${ }^{9}$. Entre outras trilhas, os bandeirantes percorreram as redes fluviais dos rios Tietê, Paraíba do Sul, Paranaíba, Madeira, Tapajós, Tocantins e as bacias do Paraná e do Paraguai ${ }^{10}$. Num momento posterior, no século XVIII, com as monções (expedições fluviais rumo ao Centro-Sul para a mercancia e a busca de metais), os rios passaram a ser as vias preferidas.

Assim como Sérgio Buarque de Holanda, Demétrio Magnoli também frisou a relação entre os rios e as fronteiras. Inicialmente, abordou o mito da Ilha Brasil. Segundo esse mito, existia um todo geográfico (Ilha Brasil) envolvido pelas águas de dois grandes rios, cujas nascentes situavam-se em um grande lago unificador. Para Magnoli, o expansionismo português serviu-se dessa lenda para erguer a mitologia cartográfica da Ilha Brasil e, assim, expandir as fronteiras traçadas pelo Tratado de Tordesilhas. Muitas cartas quinhentistas e seiscentistas delinearam o contorno dessa ilha de proporções continentais, emoldurada pelas águas dos rios Amazonas e da Prata, que se encontravam depois de percorrerem arcos convergentes. Desse modo, existiria um todo geográfico, uma terra preexistente, a qual era herdada pelos portugueses. Conforme lembrou Magnoli, a hipótese de que o Império português instrumentalizou o mito da Ilha Brasil para justificar ideologicamente a expansão do seu território foi primeiramente formulada por Jaime Cortesão. Desse modo, "[...] ao

\footnotetext{
${ }^{8}$ HOLANDA, 1975, p. 34.

9 lbid., p. 34

${ }^{10}$ QUEIROZ, 2006, p. 724.
} 
invés de conquista e exploração colonial, dádiva e destino." 11

Saltando de uma bacia hidrográfica a outra, a epopeia territorial bandeirante foi apropriada por Portugal para reafirmar o direito ao território contido na Ilha Brasil $^{12}$. Assim, na constituição da ideia de uma unidade natural, as águas foram evocadas para legitimar a expansão territorial além do Tratado de Tordesilhas. Conforme Magnoli:

A unicidade do território colonial lusitano, fruto de sua segregação insular, emanava da própria natureza. Uma faixa líquida contínua, formada pelo arco lendário flúvio-lacustre, emoldurava uma entidade territorial íntegra. As 'fronteiras naturais' da terra descoberta contrariavam, na sua realidade e concretude, as linhas demarcatórias de Tordesilhas. As fronteiras desenhadas pelos homens deveriam identificar o abraço divino dos grandes rios. $^{13}$

\section{Águas do Rio Ribeira e fronteiras}

Diz a população de Eldorado que uma maldição paira no município desde que um padre alterou a porta da Igreja, nos anos 1940, transformando a porta do fundo em porta da frente e fechando a antiga porta principal. Assim, a Igreja virou as costas para o Rio Ribeira. Contam que o fato deu início a uma sucessão de desventuras que só terminarão quando a Igreja voltar-se para o Rio Ribeira. Relatam que o rio ressente-se de ter sido abandonado e também sofre por ter águas cada vez menos abundantes e com menos peixes. Há dezenas de anos, o rio inquieta-se com os projetos de construção de hidrelétricas que ameaçam aprisionar suas águas. De vez em quando, manda uma enchente avassaladora. Assim, num movimento contrário, essa pesquisa pretende voltar-se para o Rio Ribeira e interrogá-lo sobre a

\footnotetext{
11 MAGNOLI, Demétrio. O corpo da pátria. Imaginação Geográfica e Política Externa no Brasil (18081912). São Paulo: Editora Moderna, p. 47.

${ }^{12}$ Demétrio Magnoli fez uma crítica aos historiadores que idealizavam a figura do bandeirante e lhe atribuíam o papel de povoador e pioneiro. Para o autor: "[...] o discurso sobre o bandeirismo tende a mascarar o papel desempenhado pela União Ibérica na expansão luso-brasileira para além do Meridiano de Tordesilhas." Também destacou que, ainda que existissem exceções, como Alfredo Ellys Junior e Cassiano Ricardo, "[...] a regra, porém, consiste em ver na unificação das coroas, quando muito, um pretexto ou uma oportunidade para a realização da necessidade histórica." (MAGNOLI, op. cit., p. 60 - 62).

${ }^{13}$ Ibid., p. 47.
} 
história dos povos que habitam as suas margens e sobre os mitos que atravessam suas águas.

O Rio Ribeira, conhecido pelos portugueses desde o início da colonização, exerceu papel fundamental no processo de interiorização. Nos séculos XVI, XVII e XVIII, foi percorrido por expedições em busca de metais preciosos. A partir do século XVII, com a formação de núcleos mineradores, africanos foram importados para o trabalho nas minas. O primeiro capítulo dessa pesquisa tratará da importância do Rio Ribeira para as penetrações no continente e para as principais atividades econômicas praticadas: a mineração e o cultivo do arroz. Nesse mesmo capítulo, será investigado o poder político e econômico daqueles que controlavam o tráfego pelo Rio Ribeira. Outra preocupação será observar os povos que passaram a ocupar a região. Africanos, desde o início da mineração, foram levados para o local e se juntaram a portugueses e indígenas ${ }^{14}$. Esses povos ocuparam a região e se apropriaram do Rio Ribeira, em cujas águas inscreveram mitos e crenças.

No capítulo dois, será abordado o mito de um ser encantado que mora nas profundezas do Rio Ribeira - o negro d'água. O mito é contado, até os dias de hoje, nas comunidades remanescentes de quilombo de Eldorado ${ }^{15}$ e Iporanga. $O$ mito será compreendido dentro da perspectiva atlântica, ou seja, entendendo as formações culturais criadas em solo americano como elaboradas a partir do encontro de povos diversos, possuidores de diferentes visões de mundo e postos em contato sob o escravismo. Como esse mito é contado por moradores de comunidades negras, o interesse maior será pelas populações africanas e afrodescendentes.

Os escravizados levados para a região do Ribeira foram, predominantemente, provenientes da África Centro-Ocidental. Então, uma preocupação dessa pesquisa será conhecer o que estava acontecendo do outro lado do Atlântico, quem eram os povos escravizados, no que eles acreditavam e quais eram seus mitos. Uma questão central será a relação do mito dos negros d'água com a escravidão. Essa discussão será realizada no capítulo três.

\footnotetext{
14 Documentos e relatos orais apontam para a presença das populações indígenas na região estudada, no entanto, elas não serão abordadas nesta pesquisa.

${ }^{15} \mathrm{Em} \mathrm{1948,} \mathrm{após} \mathrm{plebicisto,} \mathrm{o} \mathrm{município} \mathrm{Freguesia} \mathrm{(depois,} \mathrm{Vila)} \mathrm{de} \mathrm{Xiririca} \mathrm{passou} \mathrm{a} \mathrm{serchamado} \mathrm{de}$ Eldorado.
} 
Neste capítulo, e nos capítulos quatro e cinco, abordaremos o empenho português em transformar o Atlântico em um "mar cristão". Exporemos a evangelização ocorrida na África Centro-Ocidental, no capítulo quatro, e no Vale do Ribeira, no capítulo cinco. Destacaremos que, nos dois lados do Atlântico, o catolicismo foi reinterpretado segundo crenças locais. Nos capítulos seis e sete, trataremos da presença das crenças africanas no Vale do Ribeira - especialmente do culto aos mortos, no capítulo seis, e dos ritos de adivinhação e cura, no capítulo sete.

No capítulo oito, sublinharemos a circularidade de pessoas e crenças ao longo do Império português enquanto, concomitantemente, fronteiras iam sendo desenhadas. E esse é o ponto central da pesquisa: a relação entre as águas - do Rio Ribeira e do Atlântico - e as fronteiras. Levaremos em consideração as fronteiras (físicas e culturais), o rompimento de limites e a criação de novas fronteiras.

Quanto ao corte espacial, o foco da pesquisa é o Rio Ribeira de Iguape, especialmente o Baixo Ribeira (Iguape) e o Médio Ribeira (municípios de Eldorado e Iporanga, onde, atualmente, situam-se comunidades remanescentes de quilombo). Como, no Alto Ribeira, localizam-se duas comunidades remanescentes de quilombo, essa região também receberá a nossa atenção ${ }^{16}$. O tempo considerado é o da longa-duração - desde a chegada dos portugueses até os dias atuais -, embora a preocupação maior seja com os anos do escravismo, considerando-se que os mitos e crenças atravessam séculos.

Quanto às fontes primárias, foram pesquisados documentos no Arquivo do Estado de São Paulo (Ofícios da Câmara de Xiririca, Ofícios Diversos de Iguape, Sisas e Registro de Terras de Xiririca), no Museu Histórico e Arqueológico de Iguape (Caixas 223, 224, 235), no Museu Paulista (Coleção Prefeitura Municipal de Iguape/ 1774-1930/Atas da Câmara de Iguape) e na Cúria Metropolitana de São Paulo (Pasta Freguesia de Xiririca e Pasta Iguape). Os dois documentos mais relevantes para essa pesquisa foram o Livro de Tombo de Xiririca (1813-1898) e o Livro de

\footnotetext{
${ }^{16}$ Atualmente, no Médio Ribeira, localizam-se as comunidades remanescentes de quilombo de Pedro Cubas, Pedro Cubas de Cima, Sapatu, Nhunguara, São Pedro, Galvão, Ivaporunduva, André Lopes, Pilões, Maria Rosa, Praia Grande e Bombas. No Alto Ribeira, situam-se as comunidades remanescentes de quilombo de Porto Velho e Cangume.
} 
Tombo de Iguape (1816-1854). Esses documentos encontram-se, respectivamente, nas Casas Paroquiais de Eldorado e Iguape. Os livros citados foram abertos por ordem do Reverendo de Paranaguá, Dom Joaquim Júlio da Ressurreição Leal.

Iguape era subordinada à Vila de Paranaguá, dessa forma, ordens, provisões e padres fiscalizadores vinham dali. E, numa dessas visitas, em 1816, foi dada a ordem para a abertura dos Livros de Tombo. Todas as folhas dos dois livros foram numeradas e rubricadas por Dom Joaquim, o qual explicou que o Livro de Tombo servia para contar a história da localidade, descrever seus limites e definir os usos e os direitos paroquiais. O Livro de Tombo de Iguape (1856-1903), localizado na mesma paróquia, também foi consultado. Quanto à região da África CentroOcidental, a obra do capuchinho italiano João Antonio Cavazzi de Montecúccolo, sobre a missão capuchinha em Angola, Matamba e Congo (1645 - 1670), foi analisada.

Fundamental para essa pesquisa foi o contato com as Comunidades Remanescentes de Quilombo do Vale do Ribeira decorrente do meu trabalho como técnica de campo da Fundação ITESP ${ }^{17}$. A maioria dos mitos, crenças e tradições foram coletadas quando eu trabalhava no escritório localizado no município de Eldorado (entre os anos de 2001 e 2008). Desse contato com os quilombolas, surgiu o interesse pela pesquisa ${ }^{18}$.

\footnotetext{
${ }^{17}$ A Fundação Instituto de Terras do Estado de São Paulo "José Gomes da Silva" (ITESP), vinculada à Secretaria da Justiça e da Defesa da Cidadania, foi criada pela Lei 10.207, de 8 de janeiro de 1999, tendo por objetivo planejar e executar as políticas agrária e fundiária no âmbito do Estado de São Paulo. Uma de suas áreas de atuação é a assistência às comunidades remanescentes de quilombo, sendo o órgão estadual responsável pelos estudos necessários para a identificação e o reconhecimento dessas comunidades, a demarcação e titulação de seus territórios, a assistência técnica e o apoio para o desenvolvimento socioeconômico.

${ }^{18}$ Também muito relevante para essa pesquisa foram as atividades realizadas ao longo do curso de pós-graduação. Em 2010, cursei a disciplina "Comércio, poder e catolicismo: o caso da rainha Njinga" (FLH 5240), ministrada pela profa. Dra. Marina de Mello e Souza. O Seminário "USP-Vanderbilt: as Américas e o Mundo Atlântico" (04 e 05 de agosto de 2010) também colaborou para o desenvolvimento desta pesquisa. Também destaco a contribuição dos colegas nos eventos em que a pesquisa foi apresentada: "V Encontro de Pós-Graduandos da Faculdade de Filosofia, Letras e Ciências Humanas" (23 de novembro de 2010), "XXVI Simpósio Nacional de História" (21 de julho de 2011) e "10 Seminário Interno do Núcleo de Apoio à Pesquisa Brasil África" (03 de maio de 2012). As discussões na linha de pesquisa "Escravidão e História Atlântica" e no grupo do NAP (Núcleo de Apoio à Pesquisa Brasil África) também foram muito proveitosas.
} 


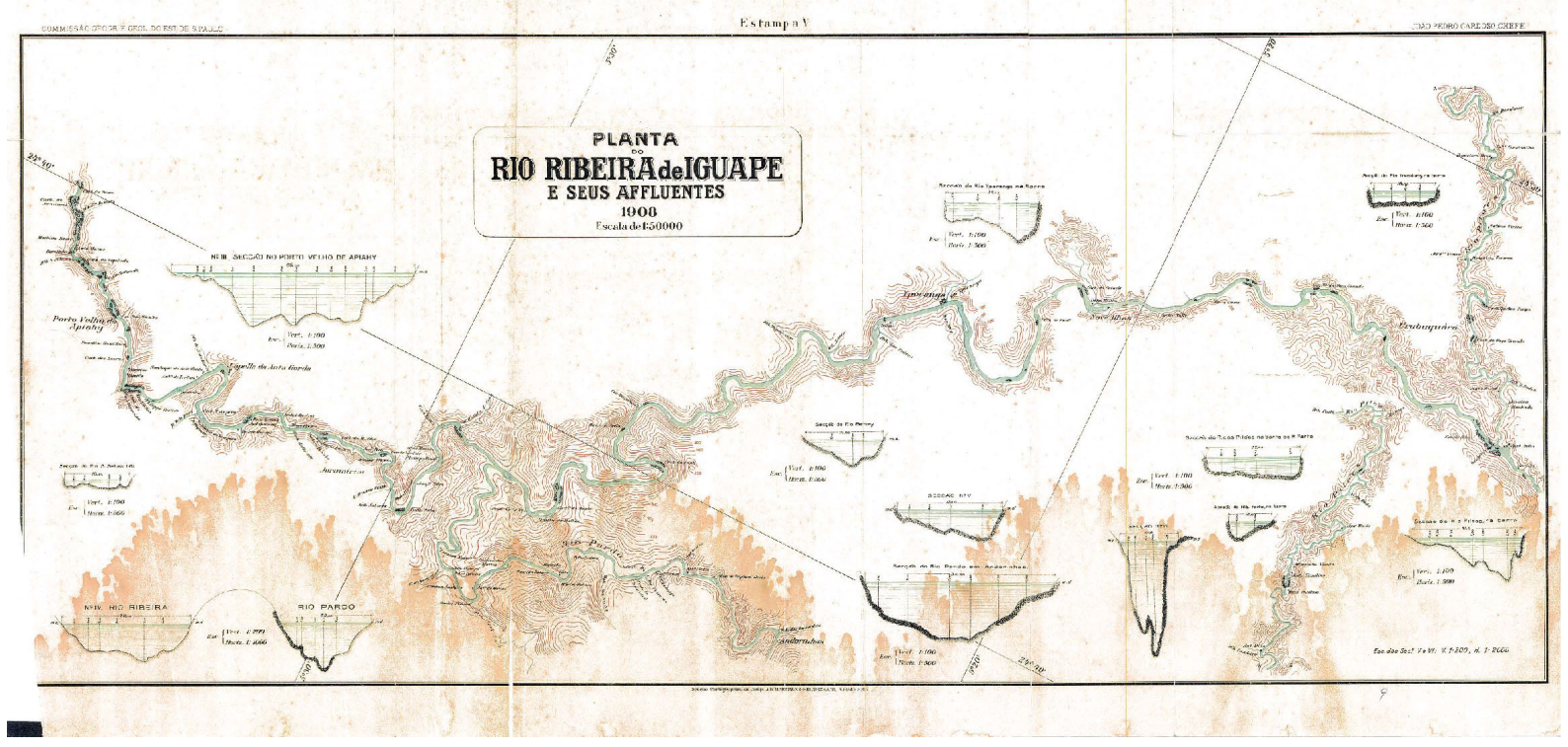



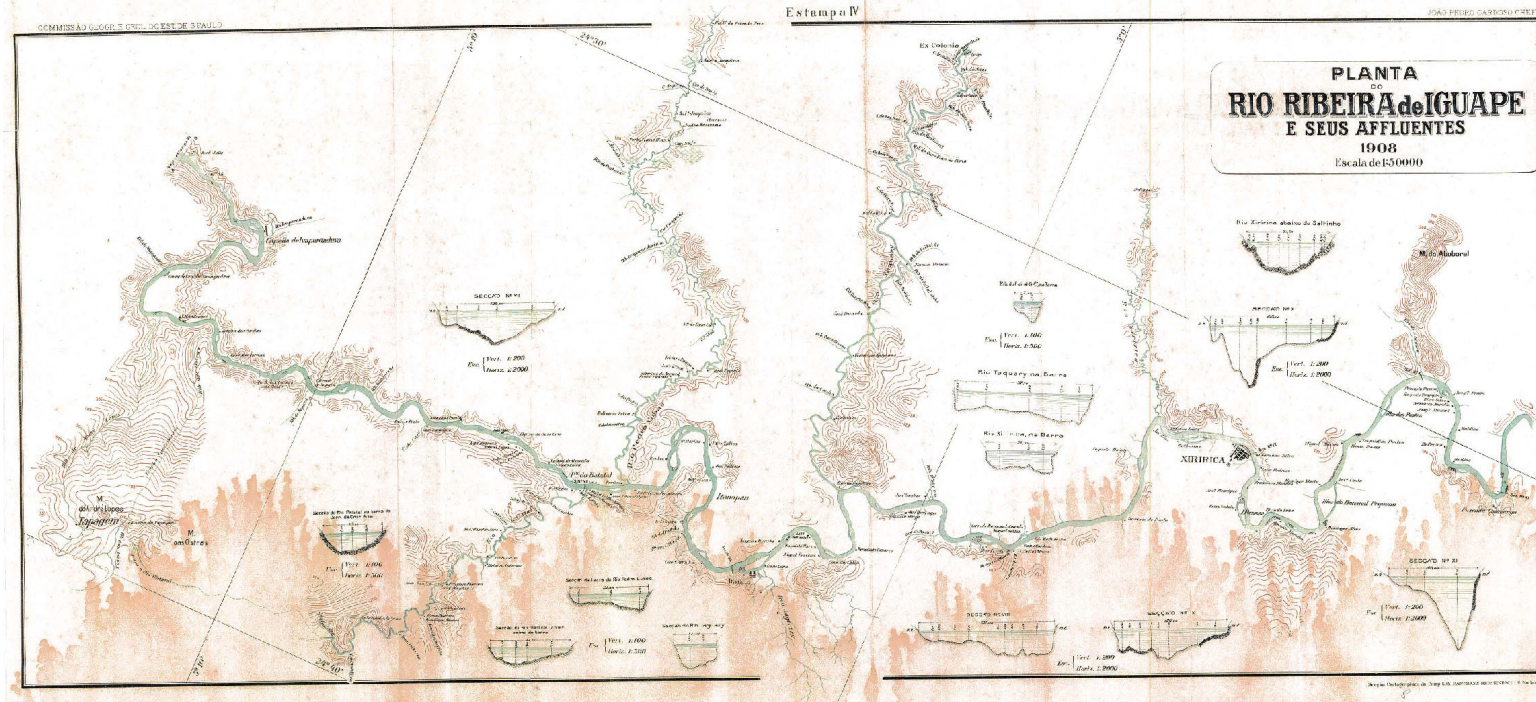
SEUS AFFLUENTES

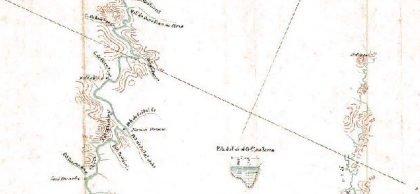

1908
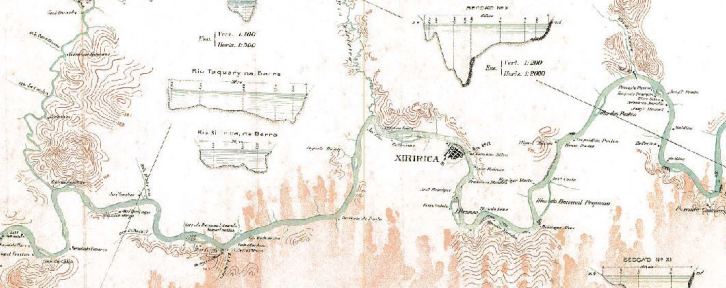


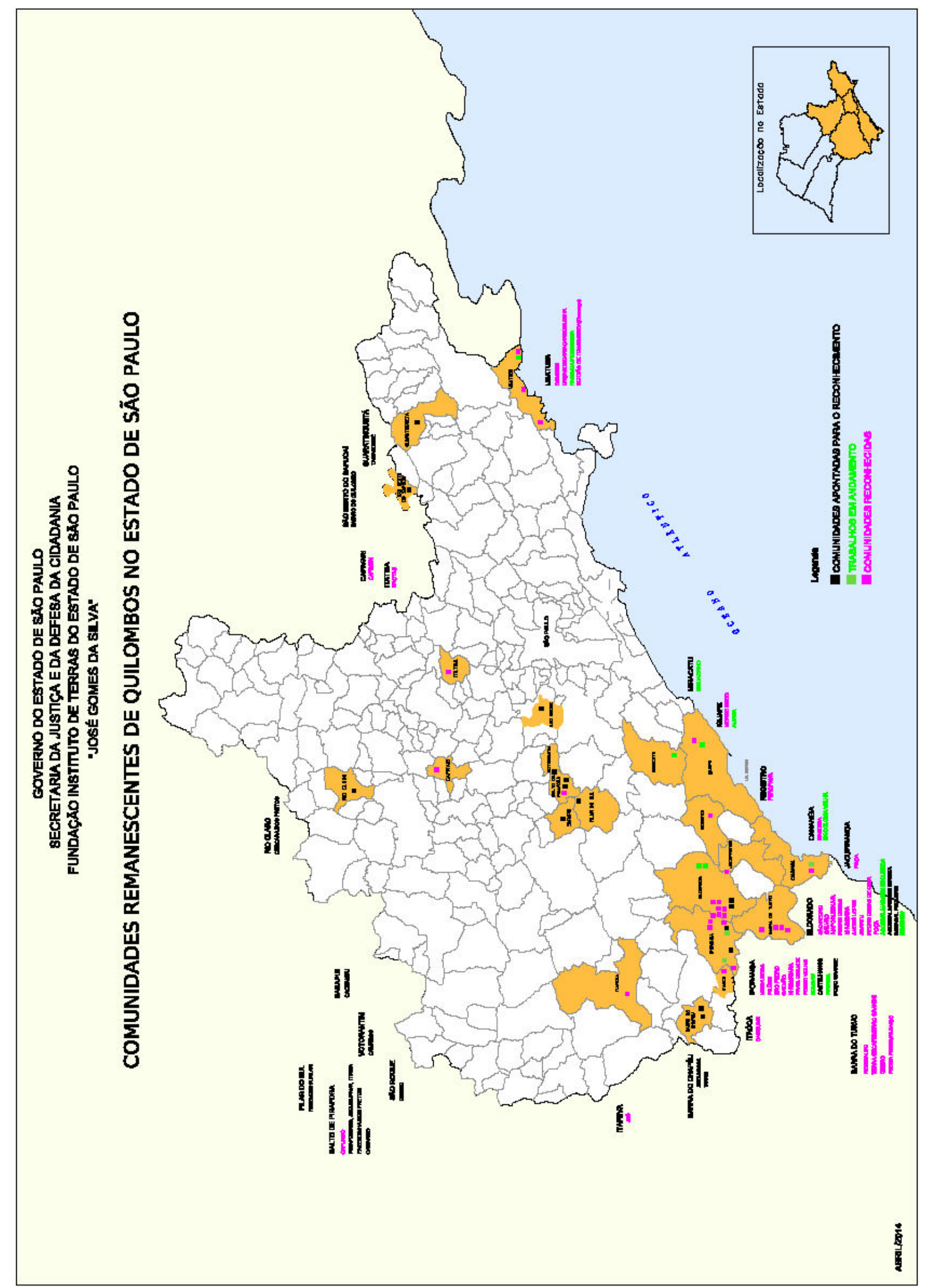




\section{Capítulo 1 - Contexto Geral}

\subsection{Rio da Interiorização}

Percorrer o Rio Ribeira é uma das formas de transpor a Serra do Mar. No topo de uma de suas serras - a Serra de Parapiacaba - localizam-se as nascentes do rio, cujas águas deságuam no Atlântico após correrem 520 km ao longo da Serra do Mar.

Atravessado por indígenas, cuja antiguidade da presença é comprovada pelos numerosos sambaquis existentes desde o litoral até próximo das suas cabeceiras, o Rio Ribeira também foi atravessado por europeus logo após o descobrimento do Brasil.

A expedição exploratória de Américo Vespúcio investigou a costa brasileira, batizou acidentes geográficos e, em 1502, ao passar pela região da foz do Rio Ribeira, abandonou um homem numa ilha perto do continente. Segundo o historiador Young, esse homem chamava-se Cosme Fernandes ou Cosme Fernandes Pessoa, era um bacharel português e tinha cometido um crime em sua terra natal, daí a razão do degredo. Como a obtenção do título de bacharel era algo raro e de grande distinção social, passou a ser conhecido na região como o Bacharel de Cananéia. Ele foi aceito pelos indígenas que viviam no litoral, integrouse, teve filhos e assumiu um papel de liderança no núcleo populacional formado próximo à foz do rio Icapara. Esse local passou a ser conhecido como lguape ${ }^{19} \mathrm{Na}$ obra de Young, o Bacharel de Cananéia e a região de Iguape são enaltecidos ${ }^{20}$.

\footnotetext{
${ }^{19}$ YOUNG, Ernesto Guilherme. História de Iguape. Revista do Instituto Histórico e Geográfico de São Paulo, São Paulo, Vol. VIII, 1904, p. 224-225.

20 Segundo Roberto Fortes, Ernest William Young foi engenheiro, historiador, jornalista e político. Young nasceu em Londres no dia 10 de setembro de 1850. Em 1871, atraído pelas possibilidades econômicas, aportou no Brasil. Ele fixou residência em Iguape, onde foi representante de várias companhias de navegação, como a Hammond e a Companhia de Navegação e Mineração Sul Paulista. Também atuou na esfera política. Foi eleito vereador em 1895 e, no seguinte, assumiu o posto de intendente. Interessado na história da localidade, pesquisou os arquivos existentes e publicou grande parte de sua obra na Revista do Instituto Histórico e Geográfico de São Paulo. Em
} 
Outros autores apresentaram diferentes visões ${ }^{21}$.

A região do Rio Ribeira localizava-se próxima à linha imaginária do Tratado de Tordesilhas, que separava os territórios de Portugal e Espanha. Ao sul, o território português findava 12 léguas abaixo de Cananéia ${ }^{22}$. Ao oeste, o limite situava-se nas proximidades do atual município de Apiai ${ }^{23}$. A América tinha sido descoberta pelos ibéricos recentemente, e ambos os impérios esforçavam-se para ampliar seus domínios.

Logo no início, riquezas minerais foram descobertas no território espanhol. Como eram escoadas pelo rio da Prata, expedições (espanholas e portuguesas) em direção a esse rio passaram a ser frequentes. Em 1508, a expedição espanhola, comandada por Vicente Yanez Pinzon e Juan de Solis, deixou seis ou sete castelhanos na barra de Cananéia ${ }^{24}$. Esses europeus juntaram-se ao núcleo liderado pelo Bacharel de Cananéia, também foram aceitos pelos indígenas e tiveram filhos. Entre os castelhanos, podemos destacar alguns nomes, como Francisco Chagas, Aleixo Garcia e Ruy Garcia de Mosqueira. Interessados em metais preciosos,

1901, foi aceito como sócio honorário dessa instituição. Ele também fundou o semanário "Comarca de Iguape" e se empenhou para a criação de um museu. Em 1907, foi inaugurado o museu da cidade e Young foi escolhido para o cargo de diretor, posição que manteve até o seu falecimento, ocorrido no dia 26 de outubro de 1914, aos 64 anos. Fortes, Roberto. Major Young, Um inglês que fez lguape. Disponível em: <http://robertofortes.fotoblog.uol.com.br/photo20050202194012.html.> Acesso em 29 de abril de 2014.

21 Conforme Ronaldo Vainfas, o Bacharel foi um "personagem misteriosíssimo do tempo das primeiras viagens portuguesas ao litoral sul do Brasil, cuja identidade não se conseguiu jamais descobrir. Sua alcunha deriva da observação do navegador espanhol Diego Garcia que, nas memórias que posteriormente ditou sobre sua viagem, mencionou ter encontrado, por volta de 1527 , em Cananéia, um "bachiller" português que ali residia 'com vários genros' há quase 30 anos. Chamou-o de bachiller, bacharel em português, provavelmente na acepção de que era um homem muito falastrão - um dos sentidos vulgares da palavra no castelhano da época". E ainda acrescentou "o Bacharel de Cananéia foi confundido com inúmeros personagens que, como ele, eram degredados, náufragos e desertores que habitavam o litoral há tempos. Foi confundido com João Ramalho, o degredado vicentino que vivia entre os tupiniquins de São Vicente. Foi confundido com Gonçalo da Costa e com Francisco Chaves, dois de seus presumidos genros. Seja como for, é de todo impossível saber quem foi o Bacharel, talvez o mais obscuro dos degredados que habitavam a costa brasílica na época". VAINFAS, Ronaldo (org). Dicionário do Brasil Colonial (1500-1808). Rio de Janeiro: Editora Objetiva, 2000, p. 62-63.

${ }^{22}$ MADRE DE DEUS, Frei Gaspar da. Memória para a História da Capitania de São Vicente. Belo Horizonte: Itatiaia/ Edusp, 1975, p. 30.

${ }_{23}^{2}$ LUZ, Rubens Calazans. Santo Antonio das Minas de Apiahy. São Paulo: Gráfica Regional, 1996, p. 31.

${ }^{24}$ YOUNG, 1904, p. 224-225. 
embrenharam-se continente adentro. Em $1524^{25}$ ou $1526^{26}$, partiu uma expedição comandada por Aleixo Garcia. Atravessou o Guairá, o Iguaçu, o Paraguai e o Alto Chaco, atingindo as regiões de Potosi e Sucre. A expedição atacou populações incaicas e retirou-se com os despojos ${ }^{27}$. Ao retornarem, com exceção de uma criança e dois homens, todos os integrantes da expedição foram mortos por indígenas ${ }^{28}$.

Além da busca de ouro e prata, o núcleo de europeus estabelecidos na foz do rio Icapara também se dedicou a abastecer as embarcações que rumavam em direção ao Rio da Prata. Em 1526, por exemplo, a expedição espanhola comandada por Diego Garcia deles recebeu carne, peixe e outros mantimentos ${ }^{29}$.

Em Portugal, chegavam notícias da América e suas riquezas. Em 1526, Diego Garcia escreveu a D. João III e discorreu sobre a existência de muito ouro nos lugares por onde tinha estado ${ }^{30}$. Martim Afonso de Souza ficou encarregado da missão de "[...] reconhecer o famoso Rio da Prata e a Costa mais Austral do Brasil e nela fundar uma ou mais Colônias"31. Martim Afonso de Souza teve acesso aos relatos dos expedicionários Solis, Rodrigo de Acuna e Diogo Garcia sobre a região da foz do Rio Ribeira e acreditava ser este um ponto favorável para a busca de metais preciosos ${ }^{32}$. Assim, partiu de Portugal e, no dia 12 de agosto de 1531, aportou nas proximidades da foz do Rio Ribeira, na ilha do Abrigo ${ }^{33}$.

Os europeus estabelecidos na foz do rio Icapara foram ao encontro de Martim Afonso de Souza e abasteceram a tripulação. Dentre eles, o castelhano Francisco de Chagas se sobressaiu ao servir de intérprete para Martim Afonso de Souza e ser chamado de "gran lingua da terra". A familiaridade com a língua era consequência

\footnotetext{
${ }^{25}$ Ibid., p. 290.

${ }^{26}$ MAFFEY, Lucy de Abreu; NOGUEIRA, Arlinda Rocha. O ouro na Capitania de São Vicente nos Séculos XVI e XVII. Anais do Museu Paulista, v. 20, p. 8-35, 1966, p. 09.

27 Ibid., p. 09.

${ }^{28}$ No século XIX, o mineralogista Henrique Ernesto Bauer achou, no Médio Ribeira, um machado de bronze de origem peruana. Para Young, este objeto fazia parte do saque realizado pela expedição comandada por Aleixo Garcia. (YOUNG, Ernesto Guilherme. Subsídios para a história de Iguape. Revista do Instituto Histórico e Geográfico de São Paulo, 1901, p. 291.)

${ }^{29}$ Ibid., p. 288.

${ }^{30}$ MAFFEY; NOGUEIRA, 1966, p. 09.

${ }^{31}$ MADRE DE DEUS,1975, p. 149.

32 ALMEIDA, Antonio Paulino. Memória Histórica de Xiririca (El Dorado Paulista). Boletim Volume 14, São Paulo: Departamento do Arquivo do Estado de São Paulo / Secretaria da Educação, 1955.

${ }^{33}$ YOUNG, 1901, p. 289.
} 
de um convívio de muitos anos com os indígenas e sugeria aprofundado conhecimento sobre a região. Francisco Chagas afirmou saber onde existiam metais preciosos e convenceu Martim Afonso de Souza a formar uma bandeira rumo ao interior. Garantiu que a bandeira retornaria em dez meses com quatrocentos cativos carregados de ouro e prata. Assim, apenas vinte dias após da chegada da esquadra de Martim Afonso de Souza, no dia 01 de setembro de 1531, partiu a primeira bandeira rumo ao interior, comandada por Pero Lobo e composta por oitenta homens.

As previsões de Francisco Chagas, no entanto, não se realizaram. Os integrantes da bandeira não retornaram ${ }^{34}$. Os autores que abordaram esse episódio concordam que os integrantes da bandeira foram mortos por indígenas, porém, não há consenso sobre o local do extermínio. Madre de Deus acredita que a bandeira tenha sido aniquilada nas proximidades do local de partida, no recôncavo de Cananéia $^{35}$. Já Almeida defende que o massacre tenha acontecido num dos subafluentes do Rio Ribeira, o rio das Mortes ${ }^{36}$. Para Young, a derrota da bandeira ocorreu na volta dos confins do atual território do Peru. Pela proximidade que existia entre os castelhanos Aleixo Garcia e Francisco Chagas, Young supõe que a bandeira de Pero Lobo, planejada por Francisco Chagas, tenha seguido o trajeto anteriormente realizado pela expedição de Aleixo Garcia ${ }^{37}$.

Outro castelhano que participava do núcleo de europeus estabelecidos na foz do rio Icapara era Ruy Garcia de Mosqueira. Definido por Young como "turbulento e desassocegado", Mosqueira entrou em conflito com os moradores de São Vicente ${ }^{38}$ e acompanhou a expedição de D. Alvaro Cabeça de Vaca pelo rio Paraná e por montes e rios do atual estado de Santa Catarina. Realizou algumas viagens ao rio da Prata, onde permaneceu por vários anos. Retornou a Iguape em 1577 e faleceu logo em seguida.

Além das expedições rumo ao Rio da Prata, foram montadas bandeiras que

\footnotetext{
34 Ibid., p. 290-291.

${ }^{35}$ MADRE DE DEUS, op. cit., p. 107.

${ }^{36}$ ALMEIDA, Antonio Paulino. Memória Histórica de Cananéia. São Paulo, 1963. Revista de História, n.26, p. 133.

${ }^{37}$ YOUNG, 1901, p. 290-291.

38 Segundo Young, entre 1533 e 1537, Mosqueira envolveu-se no conflito entre os moradores de São Vicente e Iguape. Estes últimos saquearam a Vila de São Vicente, levando até mesmo o livro de Tombo dessa localidade. (YOUNG, 1904, p.27).
} 
exploravam o território português. Portugal tinha esperança de, assim como a Espanha, achar vultosas riquezas no seu próprio território. Em 1549, o padre da Companhia de Jesus Simão Vasconcelos afirmou que os rios da capitania de São Vicente eram ricos em ouro e prata ${ }^{39}$.

Das proximidades da foz do Rio Ribeira, partiam bandeiras que revolviam as suas águas, as suas margens e as de seus afluentes, explorando as matas e subindo as escarpas da Serra da Paranapiacaba. Em 1560, Brás Cubas, o fundador da Vila do Porto de Santos, realizou a primeira descoberta de ouro em território português. O ouro foi descoberto, possivelmente, nas proximidades das nascentes do Rio Ribeira, no atual município de Apiaí. Em seguida, foi achado ouro em Sorocaba, no Jaraguá e em outros pontos da Capitania de São Vicente ${ }^{40}$.

Além das expedições em busca de metais preciosos, missões evangelizadoras também passaram pela região da foz do Rio Ribeira. Os jesuítas foram os primeiros religiosos que apareceram, dentre eles, o primeiro padre que chegara a Iguape, Pedro Correa. Ele já vivia no Brasil quando chegaram os jesuítas em 1549. Nesse mesmo ano, Pedro Correa entrou para a Companhia de Jesus e empenhou-se com entusiasmo na conversão do gentio. Pregou em Iguape e principiou a construção de uma igreja. Convocado pelo Padre Anchieta para a missão do Paraguai, partiu da região acompanhado pelo Irmão João de Souza. Esses religiosos foram mortos por indígenas e, por isso, são considerados protomártires da Companhia de Jesus na América ${ }^{41}$.

Os trabalhos religiosos de Pedro Correa tiveram continuidade. A Igreja foi concluída e Nossa Senhora das Neves foi escolhida como orago. Em 1577, foi aberto um Livro de Tombo $^{42}$. Outras missões jesuíticas transitaram pela região.

Assim, no início da colonização, a região do Ribeira foi percorrida tanto por expedições bem-aventuradas na sua busca por riquezas e propagação da fé cristã, quanto por expedições que se defrontaram com um desventurado fim.

\footnotetext{
${ }^{39}$ MAFFEY; NOGUEIRA, 1966, p. 4.

40 lbid., p. 18.

${ }^{41}$ LEITE, Serafim. Cartas dos Primeiros Jesuítas do Brasil. Edição para a Comissão do IV Centenário da Cidade de São Paulo. Coimbra: Atlântida, 1956, p. 44.

${ }^{42}$ Segundo Young, este Livro de Tombo desapareceu em 1858. Também afirmou que, nesse mesmo ano, o Vigário Antonio Carneiro da Silva Braga copiou alguns dos seus trechos e que a Câmara Municipal também transcreveu algumas partes desse documento. (YOUNG, 1904, p.228 e 335).
} 


\subsection{Rio das Riquezas}

Logo nos primeiros anos do século XVII, em 1603, o interesse metropolitano pelas riquezas minerais e pelas minas de ouro e prata recém-descobertas no Brasil fizeram com que o Rei D. Felipe II baixasse o "Regimento das Minas do Brasil", instituindo, deste modo, a cobrança do quinto ${ }^{43}$.

As buscas por ouro e prata continuaram no século XVII. No dia 16 de dezembro de 1606, Clemente Álvares declarou, na Câmara da Vila de São Paulo, que tinha passado os últimos catorze anos pesquisando metais preciosos e citou as regiões do Jaraguá, Parnaíba e Ibituruna como auríferas ${ }^{44}$. Pelo Rio Ribeira e seus afluentes, bandeiras exploravam pedregulhos, águas e areias. Desviavam e secavam rios. E, assim, acharam ouro em veios, leitos, cascalhos e corredeiras ${ }^{45}$. Uma Casa de Fundição foi edificada no Baixo Ribeira, na Vila de Iguape, e recolhia, fundia e "quintava" o ouro extraído da região do Ribeira ${ }^{46}$.

Como exemplo de exploradores que circularam ao longo do Rio Ribeira, podemos citar os irmãos Domingos e Antônio Rodrigues da Cunha ${ }^{47}$. Em meados do século XVII, exploraram lavras no Médio Ribeira, nos arraiais de Ivaporunduva e Iporanga. Domingos também permaneceu no Baixo Ribeira, em lguape, por um ano, tentando vender a lavra que possuía no arraial de Ivaporunduva. Além de circularem pelo Baixo e Médio Ribeira, também mineraram no Alto Ribeira, em Santo Antônio das Minas de Apiahy ${ }^{48}$.

Santo Antônio das Minas de Apiahy foi fundada por volta do ano de 1.600 pelos mineradores, vindos da parte baixa do Rio Ribeira, que se estabeleceram nas

\footnotetext{
${ }^{43}$ MAFFEY; NOGUEIRA, 1966, p. 31.

${ }^{44}$ Ibid., p.35.

${ }^{45}$ MANCEBO, Oswald. Apiaí: do sertão à civilização. São Paulo: Ômega, 2001, p.16-17.

${ }^{46}$ YOUNG, 1901, p.289.

47 Informação baseada na petição movida por Domingos contra seu irmão Antônio Rodrigues da Cunha, publicada por Young.

${ }^{48}$ LUZ, Rubens Calazans. Santo Antonio das Minas de Apiahy. São Paulo: Gráfica Regional, 1996, p. 27 e 56.
} 
margens do rio Pião ${ }^{49}$, nas nascentes do Rio Ribeira. Graças à extração de ouro nos rios da região, a localidade prosperou ${ }^{50}$.

A quantidade de ouro extraída no Alto Ribeira durante os séculos XVII e XVIII foi expressiva. Isto possibilitou a importação de mão-de-obra africana, além de despertar a atenção da Coroa portuguesa. Em 1722, Antônio Caldeira Pimentel, recém-empossado Capitão General da Capitania de São Paulo, visitou as minas de Apiahy e do Paranapanema (atual município de Capão Bonito) para recolher o Real Donativo $^{51}$.

Em 1736, a localidade recebeu o título de freguesia e passou a ser denominada Freguesia de Santo Antonio de Apiahy. Poucos anos depois, os mineradores da freguesia sofreram um revés: o ouro de aluvião da região do Pião findou-se ${ }^{52}$. Assim, por volta do ano de 1750, a sede da freguesia foi transferida para as imediações do Ribeirão Água Limpa, onde já existia uma concentração de mineradores ${ }^{53}$. Também já existia um adensamento de cativos, os quais, juntamente com os forros, tinham construído uma capela em homenagem a São Benedito. Neste segundo assento da freguesia, foi construída uma igreja consagrada a Santo Antonio de Lisboa $^{54}$.

A segunda sede da freguesia não foi explorada por muito tempo. Rapidamente, o ouro esgotou-se. Concomitantemente, na década de 70 , foi descoberta uma nova reserva aurífera no espigão mestre da Serra da Paranapiacaba, a 1.060 metros de altitude, no local que passou a ser designado como "Morro do Ouro". Esses fatos fizeram com que a sede de Santo Antonio de Apiaí fosse novamente transferida. O local escolhido para o novo assento foi um terreno a oeste do Morro do Ouro e antigamente chamado de "Arraial do Morro". A

\footnotetext{
${ }^{49}$ Este rio é um dos formadores do rio Apiaí Guaçu, o qual, por sua vez, se coverterá no Rio Ribeira. Quanto à denominação do rio, Calazans ressaltou que a palavra "pião" lembrava o garimpo, porque os mineradores chamavam de "pião" a parte funda do instrumento de trabalho conhecido como batéia - uma gamela afunilada e acentuadamente côncava. Destacou que, em virtude do seu peso, o ouro ficava depositado no "pião" após o encarregado da bateia imprimir-lhe movimento ritmado de rotação. (lbid., p.40 e 26)

${ }^{50}$ MANCEBO, 2001, p.37.

${ }^{51}$ LUZ, op. cit., p.29.

${ }^{52}$ MANCEBO, op. cit., p.41.

${ }^{53}$ A região ficou conhecida como Vila Velha e é onde, atualmente, localiza-se o município de Cordeirópolis.

${ }^{54}$ LUZ, 1996, p.40.
} 
nova descoberta provocou um surto expansionista na localidade, com um acentuado crescimento populacional, tanto da população livre quanto da população cativa ${ }^{55}$.

Um pouco antes desta transferência, em 1771, o Capitão General da Capitania de São Paulo, Dom Luiz Antonio de Souza Botelho, o Morgado de Mateus, objetivando concentrar a população da capitania em vilas para exercer maior controle e, assim, ser mais bem sucedido na arregimentação de homens para compor milícias, concluíra que a freguesia de Santo Antônio de Apiaí deveria ser elevada a vila. Desta forma, a Vila de Santo Antônio de Apiaí tornou-se independente da Vila de Sorocaba. A Capela do Ribeira (origem do município de Ribeira) e o Arraial de Iporanga, no Médio Ribeira, juntaram-se à nova vila criada ${ }^{56}$. Além da questão administrativa e militar, as reservas auríferas de Santo Antônio de Apiaí também contribuíram para aumentar o interesse do governo pela localidade ${ }^{57}$.

No governo da Capitania, após Morgado de Mateus, o poder foi assumido pelo Capitão General Martim Lopes Lobo de Saldanha. Sua correspondência com a Câmara da Vila de Santo Antônio de Apiaí mostrava sua preocupação em arregimentar homens para o Real Serviço, bem como sua suspeita de que os apiaienses extraviavam os metais achados no Morro do Ouro. Lobo de Saldanha interditou a atividade mineratória no morro, ordenou que fossem realizadas rondas e patrulhas e mostrou insatisfação com a escolha, feita pela Câmara, do novo guardamor das minas do Morro do Ouro ${ }^{58}$. Convocou o sargento-mor, o juiz municipal, dois vereadores e o procurador da vila para uma audiência na capital. Como não compareceram, Lobo de Saldanha ordenou que todos os convocados fossem encaminhados à prisão ${ }^{59}$. Esses fatos revelam que a relação entre Lobo de Saldanha e o poder local da vila foi caracterizada pela tensão e pelos choques constantes ${ }^{60}$.

Depois de Lobo de Saldanha, o próximo Capitão General da Capitania foi

\footnotetext{
${ }^{55}$ VALENTIN, Agnaldo. Nem Minas, nem São Paulo: economia e demografia na localidade paulista de Apiaí (1732-1835). 2001. Dissertação (Mestrado em História) - Faculdade de Filosofia, Letras e Ciências Humanas da Universidade de São Paulo, São Paulo, 2001, p. 18, p. 31, p. 40, p. 85 e p. 113.

${ }^{56}$ LUZ, op. cit., p.31.

${ }^{57}$ VALENTIN, op. cit., p. 81-82.

${ }^{58}$ VALENTIM, 2001, p.107.

${ }^{59}$ LUZ, op. cit., p.54.

${ }^{60}$ VALENTIN, op. cit., p. 108.
} 
Francisco da Cunha Meneses. Em 1784, o Capitão-Mor da Vila de Santo Antônio de Apiaí, Mathias Leite Penteado, pediu autorização ao Capitão General da Capitania para verificar a existência de ouro nos rios Jacupiranga e Turvo, localizados na Vila de Iguape. Esse interesse do capitão-mor pode sugerir que a produção aurífera de Apiaí apresentava, novamente, sinais de decadência ${ }^{61}$. Reforçando esta hipótese, o percentual da população cativa em 1798 (46,6\%), embora elevado, declinou em relação ao percentual encontrado em $1784(56,9 \%)^{62}$.

Há relatos que apontam para a ocorrência de uma grande desventura no Morro do Ouro. Entre 30 e 40 cativos, segundo Mancebo ${ }^{63}$, ou mais de uma centena, conforme $\mathrm{Luz}^{64}$, teriam morrido soterrados em consequência do desmoronamento de terras numa galeria. $O$ fato pode ter sido causado pela intensificação da exploração da mão-de-obra, realizada de forma precária, frente ao escasseamento do ouro.

Os Maços de População de Apiaí do começo do século XIX não deixam dúvida do esgotamento do ouro na localidade. Em 1809, apenas 4 chefes de domicílio dedicavam-se à extração mineratória. Em 1816, a mineração já não era mais praticada em nenhum fogo da vila ${ }^{65}$. Porém, em 1835, a mineração voltou a ser praticada, com resultados modestos: apenas em 9 domicílios da vila ${ }^{66}$. Viajando pela região na primeira metade do século XIX, Saint-Hilaire afirmou: "Entre Itapetininga e o oceano existem, nas matas, terrenos auríferos, mas o ouro não é abundante nessas jazidas, pelo que sua extração é feita apenas por alguns pobres faiscadores" 67 .

Se a produção aurífera foi escassa no século XIX, nos séculos anteriores, XVII e XVIII, a extração parece ter sido significativa. O elevado contingente de população cativa, atingindo percentuais mais elevados próximo do ano de 1776 , quando os escravizados compunham $62,9 \%$ da população total, também aponta para a expressividade da produção aurífera. Embora tenha sido a mais importante, esta não foi a única zona aurífera do Ribeira, haja vista que o Médio Ribeira também

\footnotetext{
${ }^{61}$ Ibid., p. 112.

62 Ibid., p.118.

${ }^{63}$ MANCEBO, 2001, p. 17.

${ }^{64}$ LUZ, op. cit., p. 38.

${ }^{65}$ VALENTIN, op. cit., p.193.

${ }^{66}$ VALENTIN, 2001, p. 233.

67 SAINT HILAIRE, Augusto de. Viagem a Província de São Paulo. Tradução Rubens Borba de Moraes. São Paulo: Martins Fontes, 1945, p. 56.
} 
se caracterizou como região mineradora. A importância da mineração pode ser percebida pelos nomes dados aos rios da região: rio Ouro Leve, rio Ouro Grosso, rio Ouro Fino, rio das Lavras, rio Catas Altas, entre outros ${ }^{68}$. Diferentemente da região do Alto Ribeira, que estava ligada à Vila de Sorocaba, o Médio Ribeira fazia parte da área de abrangência da Vila de Iguape. Iguape estendia-se desde seu núcleo, nas proximidades da foz do Rio Ribeira, até o Rio Iporanga. Segundo o Livro de Tombo de Iguape: "Achavão-se moradores pertencentes áesta Freguezia ate doze, e quinze dias de viagem nos rios Yvaporundúva, Piloens, Yporanga, que fazem sua confluencia na Ribeira, e no Ribeirão chamado Sumidouro, q.e deságua no de Yporanga".

A área mineradora da Vila de Iguape, o "disctricto das minas", compreendia os arraiais de Iporanga ${ }^{69}$ e Ivaporunduva, no Médio Ribeira. Entre os que mineraram na região, no século XVII, podemos citar os já mencionados irmãos Domingos e Antônio Rodrigues da Cunha, os quais circularam pelo Baixo, Médio e Alto Ribeira. Young publicou uma petição do ano de 1655, na qual Domingos informava ter comprado, em sociedade com seu irmão, uma lavra e dez cativos no arraial de Ivaporunduva. Esse documento também revela que Domingos passou um ano e meio explorando lavras no arraial de Iporanga. Esses episódios apontam para a antiguidade da ocupação da área e para a presença de cativos logo nos primeiros tempos de exploração das lavras.

O arraial de Ivaporunduva, também chamado Arraial das Minas, localizava-se no Rio Ribeira, na foz do rio Ivaporunduva. No Livro de Tombo de Xiririca (18131898), há a transcrição de um requerimento do ano de 1770 que informava que "[...] a maior escravatura teve o seu principio e aumento no arraial de Ivaporunduva".

Conforme Young, no final do século XVII, existia uma quantidade considerável de pessoas nas minas de Ivaporunduva, as quais demandavam um capelão:

No anno de 1691 o numero dos homens que trabalhavam nas minas de Yvupurunduba, sita na margem esquerda do Rio Ribeira, entre Iporanga e Xiririca, era grande, e, reclamando a nomeação de um capellão para a

\footnotetext{
${ }^{68}$ ALMEIDA, Antonio Paulino. Memória Histórica de Xiririca (El Dorado Paulista). Boletim Volume 14, São Paulo: Departamento do Arquivo do Estado de São Paulo - Secretaria da Educação, 1955, p. 11.

${ }_{69}$ Como citado anteriormente, em 1771, no momento em que Santo Antônio de Apiaí emancipou-se, o arraial de Iporanga passou a integrar o território da nova vila criada, deixando de fazer parte da Vila de Iguape.
} 
Igreja já edificada nesta localidade, foi nomeado o reverendo Padre Frei Antonio de Assumpção, por provisão passada no dia 8 de agosto do mesmo anno ${ }^{70}$.

Para Young, a Igreja de Ivaporunduva foi construída antes de 1691, pois frei Antonio de Assumpção não teria sido nomeado pároco da localidade se uma igreja não tivesse sido anteriormente edificada ${ }^{71}$. No entanto, segundo o Livro de Tombo de Xiririca, a Igreja de Ivaporunduva só foi construída entre os anos de 1775 e 1780. Mesmo que a igreja citada não tivesse sido edificada no século XVII, o ouro existente nos rios do Médio Ribeira atraiu um número crescente de pessoas, originárias, principalmente, da Vila de Iguape, "[...] onde como que ficando plantado o tronco d'esta Arvore, extendeu para esta Freguezia tantos ramos q.tas são as multiplicadas Familias, que hoje em dia aqui se contão entrelaçadas de parentescos" ${ }^{72}$.

Em meados do século XVIII, "[...] gemendo os moradores do Ribeira acima com grande e irremediável carencia de Suffragio, se confederarão com o Reverendo Vigario de Iguape, de erigir hua Capella" ${ }^{73}$. Assim, uma capela foi construída pelos habitantes da localidade a jusante do arraial de Ivaporunduva, nas margens do rio Xiririca. No dia oito de setembro de 1757, o vigário colado da Vila de Iguape colocou no altar da capela a imagem de Nossa Senhora da Guia, que passou a ser o orago do local $^{74}$. Foi estipulado que cada praticante da confissão pagaria meia oitava de ouro. Para patrimônio da nova capela, os irmãos Severino e Romão Veras, no dia 10 de janeiro de 1757, doaram duas moradas de casas que possuíam na Vila de Iguape "[...] para effeito de Se-conseguir o estabelecim ${ }^{\text {to }}$ de hua Capella n'este Rio da Ribeira, onde querem erigir os Moradores do dito Rio Para remedio espiritual de Suas almas"75.

Embora pagassem a contribuição estipulada, os membros da Capela não estavam satisfeitos com o auxílio religioso recebido. Assim, fizeram uma representação endereçada ao Bispo de São Paulo, Frei Antônio da Madre de Deus

\footnotetext{
${ }^{70}$ YOUNG, 1901, p. 407.

${ }^{71}$ Ibid., p. 325.

${ }^{72}$ Livro de Tombo de Xiririca (1813-1898). Paróquia de Eldorado (SP).

${ }^{73}$ Livro de Tombo de Xiririca (1813-1898). Paróquia de Eldorado (SP).

${ }_{75}^{74}$ ALMEIDA, 1955, p. 55.

${ }^{75}$ Livro de Tombo de Xiririca (1813-1898). Paróquia de Eldorado (SP).
} 
Galvão, relatando que só eram assistidos espiritualmente uma vez por ano, na época da quaresma ${ }^{76}$. No Livro de Tombo de Iguape (1816-1854), também há uma referência ao trabalho dos vigários de Iguape nas minas existentes, Ribeira acima, na época da desobriga:

[...] os Rdos. Vigarios desta hião annualmente pela Ribeira ásima a Dezobriga do povo, qe. concorria ali de todas as suas circunvizinhanças onde havião mas. Lavras de Oiro, epagavão por cada pessoa de Dezobriga meia oitava: então sefazião todas as Festas, baptizavão-se os nascidos, recommendavão-se os mortos, efazião-se os Cazamentos, ecomo havia abundancia de oiro os R.dos Parochos trazião quantidade deste metal, que fazia a maior riqueza da sua Estolla, depois qe. descobrião as Minas ${ }^{77}$.

Por não estarem satisfeitos, os membros da Capela de Nossa Senhora da Guia de Xiririca solicitaram ao bispo o desmembramento da capela. O bispo concedeu ao reverendo de Iguape o prazo de três meses para providenciar um capelão. Como esta exigência não foi atendida, o bispo desmembrou a Capela de Nossa Senhora da Guia de Xiririca da Igreja Matriz de Iguape, decretando sua elevação à freguesia ${ }^{78}$. A nova freguesia, erigida por volta do ano de 1760 , passou a abranger a região entre os rios Juquia e Ivaporunduva. A área abaixo do rio Juquiá continuou a pertencer à Vila de Iguape e a zona acima de Ivaporunduva e, por extensão, o arraial de Iporanga, passou a pertencer à Vila de Apiahy. O arraial de Ivaporunduva continuou fazendo parte de Xiririca.

Tendo-se porém erigido a Freguezia da Senhora da Guia de Xiririca em 1760 mais ou menos na margem Oriental da Ribeira logo abaixo de hum Ribeirão Fronteiro, qe. Ihe dá o nome, Yporanga com sua capela filial ficou pertencendo à Villa de Apiahi, já então fundada, e Yvaporunduva com outra Capella filial a Xiririca ${ }^{79}$.

O arraial de Ivaporunduva concentrava ouro e cativos e, por isso, foi a área economicamente mais importante da freguesia. No dia 03 de setembro de 1766, o minerador de Ivaporunduva Joaquim Machado de Moraes foi nomeado capitão de

\footnotetext{
${ }^{76}$ ALMEIDA, op. cit., p. 57.

77 Livro de Tombo de Iguape (1816-1854). Paróquia de Iguape (SP).

${ }^{78}$ ALMEIDA, op. cit., p. 56-57.

79 Livro de Tombo de Iguape (1816-1854). Paróquia de Iguape (SP).
} 
uma companhia de ordenança, assumindo, assim, o governo da freguesia ${ }^{80}$.

Os mineradores de Ivaporunduva, especialmente o Capitão Joaquim Machado de Moraes, contribuíram para que uma capela fosse edificada com o ouro dos cativos no arraial entre os anos de 1775 e 1780. Conforme o Livro de Tombo de Xiririca (1813-1898):

Concorrendo pois os senhores dos sobreditos escravos com a sua aprovação e auxilio, mormente o Capitão Joaquim Machado de Moraes, de quem já falamos, erigiu-se debaixo da Faculdade ordinária a referida capela, no lugar em que existe, pagando-se todo trabalho dos taipeiros e carpinteiros com o ouro dos mesmos escravos ${ }^{81}$.

No entanto, a mineração em Ivaporunduva estava muito próxima do seu término. Os Maços de População de 1806 mostram que não havia mais nenhum minerador em toda freguesia ${ }^{82}$. No começo do século XIX, o padre de Xiririca expressou o seu descontentamento com o término da extração de ouro:

[...] dizendo que já se não tinha ouro, e porque; Acabar-se-ia o ouro destes antigos arraiais; Certamente não, senão há ouro, é porque se não tira, por andarem entretidos na plantação de arroz, e uma vez que há muito ouro, e que não está proibido por Sua Majestade o tirar-se, não deve um motivo casual destruir um direito essencial de chamar-se Minas estes arraiais, e ter os usos de todas as igrejas de Minas, relativos aos direitos paroquiais ${ }^{83}$.

Ao padre de Xiririca interessava a continuidade da mineração, pois, dessa forma, a freguesia permaneceria sendo uma "Igreja de Minas" e seguiria o "Regimento de Minas", o qual cotava os serviços religiosos em oitavas de ouro. Apesar do seu protesto, o esgotamento do ouro já era um fato consumado e uma nova atividade, o cultivo do arroz, despontava. Assim, o "Regimento de Minas" não foi mais utilizado e a freguesia passou a ser regida segundo as determinações da Igreja Matriz de Iguape.

No arraial de Iporanga, assim como no Alto Ribeira e no arraial de Ivaporunduva, as minas de ouro também se esgotaram no final de século XVIII. O

\footnotetext{
${ }^{80}$ ALMEIDA, 1955., p. 67.

${ }^{81}$ Livro de Tombo de Xiririca (1813-1898). Paróquia de Eldorado (SP).

${ }^{82}$ Maços de População de Xiririca (1806). Rolo 72, Lata 60. Arquivo do Estado de São Paulo.

${ }^{83}$ Livro de Tombo de Xiririca (1813-1898. Paróquia de Eldorado (SP).
} 
arraial de Iporanga foi fundado por mineradores em meados do século XVII. Um século depois, em 1755, os mineradores Garcia Rodrigues Paes Calaça, José Rollim de Moura, Antonio Leme de Alvarenga e Nuno Mendes Torres reformaram uma capela construída nas proximidades do Rio Iporanga. A capela foi erigida em louvor a Santa Ana - a padroeira da localidade. Garcia Rodrigues Paes Calaça doou a imagem da santa à capela. Em 1768, Garcia Rodrigues foi nomeado pelo Capitão General da Capitania de São Paulo, d. Luiz Antônio de Souza Botelho, o Morgado de Mateus, Capitão-mor Regente de todos os Sertões de Minas da Ribeira, Paranapanema, Apiaí e Nossa Senhora da Guia de Xiririca ${ }^{84}$. No entanto, como já mencionado, a mineração caminhava para seu fim. Em 1814, habitantes de Iporanga informavam ao Bispo de São Paulo que não havia mais ouro na localidade ${ }^{85}$.

Assim, chamariz para o desbravamento da região e para o estabelecimento de núcleos populacionais, o ouro de lavagem encontrado no Rio Ribeira e afluentes exauriu-se.

O esgotamento do ouro levou à extinção dos arraiais mineradores. Muitos brancos partiram em busca de oportunidades mais promissoras em outras regiões. Para aqueles empobrecidos, a manutenção de cativos tornou-se extremamente onerosa. Assim, escravizados foram abandonados ou alforriados e transformaramse em camponeses livres.

Há relatos que apontam para a saída de brancos da região do Médio Ribeira devido a conflitos travados entre eles próprios. O geógrafo alemão Carlos Rath escreveu em 1854: "Os lavradores que viverão aqui para tirar ouro matarão uns aos outros e por isso os brancos desapparecem e só os pretos se conservarão até hoje no ribeirão Guaporunduva, Anhangueira, etc" ${ }^{86}$.

Porém, parcela da população branca permaneceu na região e alocou seus recursos (terra, água e cativos) na nova atividade econômica que, a partir do final do século XVIII, começava a ganhar vigor - a produção de arroz em escala comercial. Os arraiais mineradores foram extintos e uma nova dinâmica populacional emergiu.

\footnotetext{
${ }^{84}$ ALMEIDA, 1995, p. 48.

${ }^{85}$ KRUG, Edmundo. Xiririca, Ivaporundiba e Iporanga. Revista do Instituto Histórico e Geográfico de São Paulo, São Paulo, vol. XVIII, 2 ed., 1942, p. 302-303.

${ }^{86}$ RATH, Carlos. Fragmentos Geológicos e Geográficos para a parte Physica da Estatística das Províncias de S. Paulo e Paraná. São Paulo: Imparcial, 1856, p. 25.
} 
Numa vasta região, passaram a coexistir propriedades com cativos e núcleos de negros libertos.

Para o padre de Xiririca, saudoso da época da mineração e do "Regimento das Minas", restou a decadência. Relatou, no começo do século XIX, que o antigo arraial de Ivaporunduva estava coberto

[...] de matos, despido de tantas cazas e ranxarias, sem a pastaria de gados, q' contava, sem o reciproco commercio, que se fazia com a influencia do Oiro, dos extranhos e moradores, sem aquelle numerode escravaturas, q' era o arrimo dos Mineiros ${ }^{87}$.

Restaram os rios desviados. De acordo com Carlos Rath, em observação realizada em 1854:

No Rio Guaporunduva e principalmente nas cabeceiras delle onde se chama ribeirão das mortes, ribeirão dos Pilões, ribeirão Sta Anna, onde atravessa o caminho do Iporanga para a freguesia do Paranapanema, achase um grande serviço de quase duzentos annos nos valles, montes de cascalhos, desvios dos mencionados ribeirões, enfim aqui se vê material para uma pintura extraordinaria e horrorosa.

Restou, nas margens do Rio Ribeira, a Igreja de Ivaporunduva, "o ultimo Suspiro de tantos trabalhos e fadigas, que alli se havião empregado" ${ }^{88}$.

${ }^{87}$ Livro de Tombo de Xiririca (1813-1898). Paróquia de Eldorado (SP).

${ }^{88}$ Livro de Tombo de Xiririca (1813-1898). Paróquia de Eldorado (SP). 


\subsection{Rio da Fertilidade}

A freguesia de Iguape, fundada em 1577, sob invocação de Nossa Senhora das Neves, transferiu-se para um novo local, situado uma légua a nordeste ${ }^{89}$. Essa mudança, das margens do Rio Icapara para uma planície localizada entre o Mar Pequeno e o Rio Ribeira de Iguape, ocorreu por volta do ano de 1637, quando foi erigida uma nova igreja em homenagem à mesma santa.

O local escolhido para a edificação da nova vila ficava ao pé de uma pequena cordilheira, pertencente a uma planície mais vasta. Nessa pequena cordilheira, nasciam muitos córregos e um deles fornecia água potável para uso doméstico ${ }^{90}$. O novo local era mais próximo dos estabelecimentos agrícolas que iam se formando ao longo do Mar Pequeno e do Rio Ribeira de Iguape. A ocupação das margens do Rio Ribeira era motivada pela fertilidade das margens ribeirinhas e pela facilidade de transporte ${ }^{91}$.

Conforme Ata da Câmara da sessão realizada no dia 29 de dezembro de $1789^{92}$, a fertilidade do Rio Ribeira de Iguape exerceu papel determinante para essa mudança:

[...] seos poucos abitadores não podendo ter comoda suSistencia mudando a sua habitação para o interior mais aSima da mesma Barra distancia de huma legoa e ahy firmarão o seu novo Estabelecimento, em hum terreno aprazivel junto ao mar pequeno, e mais vezinho a Ribeira, hum dos rios mais famosos desta Capitania, cuja fertelidade, e abundancia de produçoens seria sem duvida a cauza da Sua Transmigração; aqui mais comodamente estabelecidos ficarão e premanecerão comeSsando a villa que axiste hoje, fundada no Sobre dito $\mathrm{Citio}^{93}$.

Carlos Rath também destacou a fertilidade das terras de Iguape, Xiririca e

\footnotetext{
${ }^{89}$ Livro de Tombo de Iguape (1816-1854). Paróquia de Iguape (SP).

${ }^{90}$ YOUNG, 1904, p. 239.

91 Ibid., p. 238-239.

92 A sessão da Câmara deste dia cumpria o que foi determinado pelo ouvidor da Comarca de Paranaguá, o qual tentava colocar em prática a ordem dada pela rainha Dona Maria de registrar os fatos mais notáveis que aconteceram desde a fundação da capitania. (ALMEIDA, Antonio Paulino. Memória da Vila de Iguape. Departamento de Cultura IN Separata da Revista do Arquivo, São Paulo, vol. CLI, 1852 , p. 14).

${ }^{93}$ Ata da Câmara da Vila de Iguape. (ALMEIDA, op. cit., p. 16).
} 
Apiaí $^{94}$. Contudo, essa fertilidade deve ser vista com reserva. O geógrafo Pasquale Petrone, ao pesquisar a Baixada do Ribeira (região que compreende o Baixo Ribeira e uma parte do Médio Ribeira), afirmou que os solos dessa região não são muito férteis devido a sua fragilidade, pouca profundidade e presença de materiais silicosos. Após a destruição da floresta pluvial, os solos se refaziam muito lentamente. Nas áreas de colina, as primeiras colheitas podiam ser abundantes, no entanto, em poucos anos, os solos esgotavam-se. Portanto, os solos que ofereciam melhores possibilidades localizavam-se nas áreas inundáveis, pois eram conservados pelas cheias ${ }^{95}$, o que fez com que o espaço agrário seguisse o leito dos rios. A partir da ocupação das proximidades de Iguape, a população internalizou-se, "[...] acompanhando sempre o Rio Ribeira e seus afluentes, especialmente os rios Una e Peroupaba" 96.

Na segunda metade do século XVIII, no Baixo Ribeira, o principal gênero agrícola comercializado era a mandioca ${ }^{97}$. Porém, a partir dessa época, mesmo continuando a ser cultivada como gênero de subsistência, a mandioca começou a perder para o arroz o posto de principal produto comercializado ${ }^{98}$. Ligado ao rio, pois se localizava nas áreas inundáveis ${ }^{99}$, o cultivo do arroz disseminou-se ao longo do Rio Ribeira e afluentes. Aos cultivadores de arroz importava possuir uma testada, ou seja, possuir terras com algum corpo d'água, fonte de fertilidade do solo e local de atraque das canoas, não importando tanto as medidas do terreno ${ }^{100}$.

Ao analisar as listas nominativas de 1801 e 1836 de Xiririca e Iguape, Agnaldo Valentin observou "[...] que a prática rizicultora não se restringiu a um determinado segmento produtivo, atingindo praticamente todos os rincões do Vale com ocupação humana"101. Escravistas com posses de pequeno, médio e grande

\footnotetext{
${ }^{94}$ RATH, 1856, p.02.

${ }^{95}$ PETRONE, Pasquale. A Baixada do Ribeira: estudo de geografa humana. Boletim $n^{\circ} 283$ (Cadeira de Geografia n 14). São Paulo: FFLCH - USP, 1966, p. 37-38.

${ }^{96}$ YOUNG, 1904, p. 249.

97 VALENTIN, Agnaldo. Uma civilização do arroz: agricultura, comércio e subsistência no Vale do Ribeira (1800-1880). 2006. Tese (Doutorado em História Econômica) - Faculdade de Filosofia, Letras e Ciências Humanas da Universidade de São Paulo, 2006, p. 135.

${ }^{98}$ Ibid., p. 312

99 PETRONE, Pasquale. Notas sobre os sistemas de cultura na Baixada do Ribeira, SP. Boletim Paulista de Geografia. São Paulo: Associação dos Geógrafos Brasileiros, n. 39, p. 47-63, out/1961, p. 59.

${ }^{100}$ VALENTIN, op. cit., p. 76.

${ }^{101}$ VALENTIN, 2006, p. 75.
} 
porte, não escravistas e ex-escravizados dedicaram-se à rizicultura. O cultivo do arroz foi adotado em todos os estratos econômicos.

Em Xiririca, os serviços religiosos e a contribuição para a edificação de uma nova matriz foram cobrados em alqueires de $\operatorname{arroz}^{102}$. O padre colado sublinhou que os xiririquenses andavam "entretidos na plantação de arroz" e relacionou o aumento da produção com a chegada da família real ao Brasil em 1808:

\begin{abstract}
Já desde o ano, e ainda antes, de 1790, começavam alguns moradores desta freguesia a aplicar-se a plantação de arroz, segundo as noticias daquele tempo, mas não era cultivado este genero da lavoura com tanto empenho e generalidade, enquanto senão procurava e pedia constante e anualmente, já subindo já descendo de preço, e algumas vezes inteiramente se abandonava a mais infima estimação, até que elevou-se a ser o principal fundamento do comércio desta freguesia do ano por diante de 1807. Com a transmigração de Sua Majestada Fidelissima de Portugal para este reino do Brasil [...] e fazendo-se maior e mais constante estimação deste gênero, começou a mesma sorte a ser maior a importação ou o comércio de fora de fazenda secca, molhadas e escravatura ${ }^{103}$.
\end{abstract}

Em Xiririca, além do arroz e dos gêneros de subsistência, também se cultivava cana-de-açúcar (para fabricação de açúcar e aguardente) e, em quantidade diminuta, café ${ }^{104}$. No entanto, como informava a Câmara Municipal de Xiririca ao presidente da Província em 1856, a "[...] cultura dominante é arroz, sua exportação sobe a 25 mil saccos annualmente que exporta para o Rio de Janeiro pelo porto da cidade de Iguape"105.

Além de garantir a fertilidade e o transporte, as águas dos rios desempenhavam um papel fundamental no processo produtivo, pois sua força fornecia a energia necessária para mover os engenhos d'água que processavam o arroz. Sérgio Buarque de Holanda destacou a importância da introdução de engenhos d'água na capitania de São Paulo nos três últimos decênios do século XVIII, já que os engenhos eram mais sofisticados do que o monjolo do ponto de vista tecnológico e foram responsáveis pelo fato de o arroz deixar de ser um "simples produto caseiro" para transformar-se em "um artigo comercial de certa

\footnotetext{
102 Livro de Tombo de Xiririca (1813-1898). Paróquia de Eldorado (SP).

103 Livro de Tombo de Xiririca (1813-1898). Paróquia de Eldorado (SP).

104 Ofício da Câmara de Xiririca (ano 1852) ao Presidente da Província de São Paulo. Ofícios diversos. Xiririca (ano 1822/1843-1856). Ordem 1339, lata 544. Arquivo do Estado de São Paulo.

105 Ofício da Câmara de Xiririca (ano 1856) ao Presidente da Província de São Paulo. Ofícios diversos. Xiririca (ano 1822/1843-1856). Ordem 1339, lata 544. Arquivo do Estado de São Paulo.
} 
importância"106.

O padre colado de Xiririca sublinhou a introdução dos engenhos de arroz na localidade, destacando que "[...] a indústria e arte tentaram os Engenhos de virar

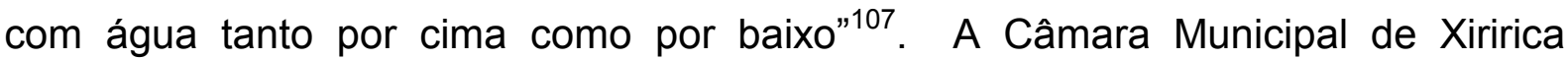
também frisou a presença dos engenhos de arroz na localidade. As listas nominativas de Xiririca e Iguape apontaram para a expansão do número de engenhos - passaram de oito engenhos, em 1801, para $71 \mathrm{em} 1836^{108}$. Os plantadores de arroz levavam sua produção para os engenhos e, assim, era concluída a etapa produtiva. Em comparação com os plantadores de arroz, os proprietários desses engenhos possuíam uma posição mais elevada na hierarquia social.

Existia uma elevada desproporcionalidade de engenhos no Médio Ribeira em comparação com o Baixo Ribeira, explicada pelas características físicas do relevo. Conforme Valentim:

\begin{abstract}
O investimento no engenho propriamente dito aparentemente nunca representou uma inversão vultosa. Movidos por energia hidráulica e construídos com madeira local, sua manutenção não deveria requisitar dispêndios excessivos por parte do proprietário. Entendemos, portanto, que o principal fator limitante à expansão destas unidades processadoras residia nas condições físicas ideais para a captação da água necessária para seu movimento. Deste requisito emerge a valorização de propriedades rurais com estas condições, principalmente em Iguape, onde a maior parte do território é conformado por áreas planas e com baixa declividade, proporcionando pequena energia potencial para a movimentação das rodas. Encontramos tal disposição com maior frequência em Xiririca, cuja área cultivável restringia-se a uma estreita faixa às margens do Ribeira e que divisavam com os contrafortes da Serra de Paranapiacaba, daí gerando as quedas d'água capazes de tocar os engenhos ${ }^{109}$.
\end{abstract}

Esta mesma região, dos contrafortes da Serra de Paranapiacaba, compreendia a área mineradora do Médio Ribeira. Diferentemente do ocorrido no Alto Ribeira, que entrou num período de estagnação econômica logo após o esgotamento do ouro, no Médio Ribeira, a rizicultura emergiu como nova atividade

\footnotetext{
${ }^{106}$ HOLANDA, Sérgio Buarque. O arroz em São Paulo na era colonial. Digesto Econômico, ano III, $\mathrm{n}^{\circ}$ 31, p. 56-58, jan. 1947.

${ }^{107}$ Livro de Tombo de Xiririca (1813-1898). Paróquia de Eldorado (SP).

${ }^{108}$ VALENTIN, 2006, p. 41.

${ }^{109}$ Ibid., p. 296.
} 
econômica nos momentos finais da exploração aurífera (segunda metade do século XVIII). Conforme abordado no capítulo anterior, o fim da mineração provocou desequilíbrio na dinâmica existente nos arraiais mineradores do Médio Ribeira. Cativos foram abandonados ou alforriados e transformaram-se em camponeses. No entanto, escravizados também foram realocados nas unidades produtoras de $\operatorname{arroz}^{110}$, assim como ex-mineradores e seus descendentes, os quais passaram a se dedicar à rizicultura.

Este foi o caso da família Morato do Canto. Em 1765, Joaquim Morato do Canto praticou atividades mineratórias em Ivaporunduva. Um de seus descendentes, Joaquim Pedro do Canto ${ }^{111}$, entre os anos de 1836 e 1861, além de um estabelecimento comercial em Xiririca, possuía engenho de arroz, engenho de cana e cativos. Entre suas propriedades, destacava-se um sítio na localidade denominada "Salto"112. Assim, podemos concluir que o escravismo perdurou na região. E, se o ouro nos leitos dos rios motivou a ocupação da área, num momento posterior, as "[...] terras ribeirinhas ganharam nova importância com a multiplicação das lavouras de arroz [...] "113, absorvendo escravistas, escravizados e homens livres.

A região de Ivaporunduva era apenas uma parte da freguesia de Xiririca. A lavoura de arroz, em unidades escravistas e não escravistas, propagou-se por toda freguesia e também em Iporanga. O pároco de Xiririca criticou a prática rizicultora e ambicionava o retorno da mineração ${ }^{114}$. Em 1817, o pároco de Iguape expressou diferente opinião. Ele considerava que a rizicultura proporcionava à vila de Iguape "dias florentes". ${ }^{115}$ A passagem para o século XIX, em Iporanga, Xiririca e, principalmente, em Iguape, correspondeu ao início de um período de dinamismo econômico, assentado, principalmente, no cultivo do arroz.

Um dos sinais deste dinamismo econômico foi o crescimento do número de africanos na região. Em Xiririca, os cativos africanos passaram de $9 \%$ do total dos cativos, em 1801, para $29 \%$ do total dos cativos em 1815 . Em Iguape, entre os

\footnotetext{
${ }^{110}$ VALENTIM, 2006, p. 135.

${ }^{111}$ Ibid., p. 276.

${ }^{112}$ Atualmente, o sítio conhecido como Salto faz parte do território da Comunidade Remanescente de Quilombo de Nhunguara.

${ }^{113}$ VALENTIN, op. cit., p. 134.

114 Livro de Tombo de Xiririca (1813-1898). Paróquia de Eldorado (SP)

${ }^{115}$ Livro de Tombo de Iguape (1816-1854). Paróquia de Iguape (SP).
} 
mesmos anos, os cativos africanos passaram de $8 \%$ para $30 \%$ do total de escravizados $^{116}$. Principalmente entre os anos de 1801 e 1828, em Iguape e Xiririca, proprietários realizaram investimentos expressivos na aquisição de escravizados. Destacamos que esse tipo de investimento também foi verificado em outras regiões paulistas $^{117}$. Em Iguape, entre 1801 e 1836, o número de proprietários cresceu $82 \%$, a população cativa aumentou $186 \%$ e a posse média passou de 4,3 para 6,7 escravizados por proprietário. Em Xiririca, o número de proprietários cresceu 87\%, a população cativa ampliou $105 \%$ e a posse média oscilou de 4,7 para 5,1 cativos por proprietário $^{118}$. A distribuição dos cativos era desigual, apontando para a existência de uma parcela de proprietários mais abastada ${ }^{119}$. Em comparação com os plantadores de arroz, os proprietários de engenhos de arroz detinham posses maiores e com maior presença de cativos do sexo masculino ${ }^{120}$. No entanto, de forma geral, há um predomínio de pequenos proprietários de cativos - fato que também ocorria na maior parte das regiões paulistas no mesmo período ${ }^{121}$.

Situação diversa ocorreu no Alto Ribeira. Principal área mineradora do Rio Ribeira, a passagem para o século XIX testemunhou o esgotamento da mineração. Como nenhuma atividade econômica emergiu com vigor suficiente para garantir dinamismo econômico, a região entrou num processo de estagnação. Um dos sinais dessa falta de dinamismo foi a diminuição do percentual de cativos ${ }^{122}$. Se, durante o período da mineração, em 1776, os cativos chegaram a representar $62,9 \%$ da população total, na virada do século, em 1798, passaram a representar $46,6 \%$, caindo para 31\%, em 1824, e 19,7\%, em 1835.

Este quadro de estagnação também pode ser vislumbrado pelo aumento de negros e mestiços entre o contingente da população livre, os quais passaram a ser predominantes. O percentual dos brancos diminuiu - em 1798, representava $41,7 \%$

\footnotetext{
${ }^{116}$ VALENTIN, 2006, p. 167.

117 Ibid., p. 170.

${ }^{118}$ Ibid., p. 170.

${ }^{119}$ Ibid., p. 185.

${ }^{120}$ Ibid., p. 199.

121 ibid., p. 200.

${ }^{122}$ A diminuição da população cativa nas primeiras décadas do século XIX em Apiaí contrastou com o que ocorreu no restante de São Paulo. Maria Luiza Marcílio observou que, entre 1798 e 1818, a população cativa aumentou $97 \%$ na capitania (e depois província) de São Paulo. (MARCíLIO, Maria Luiza. Crescimento Demográfico e Evolução Agrária Paulista, 1700-1836. São Paulo: Edusp/ Hucitec, 2000).
} 
da população livre e, em 1809 , decresceu para $32,1 \%{ }^{123}$. Os pardos passaram também a representar uma parcela significativa de proprietários de cativos. Eram pardos $29 \%$ dos escravistas, em 1809, 38,1\% dos escravistas, em 1816, e $65 \%$ dos escravistas, em $1835^{124}$. O elevado percentual de pardos entre os escravistas pode ser atribuído a um intrincado processo de partilhas que envolvia a legitimação de herdeiros naturais filhos de proprietários com suas antigas escravas ${ }^{125}$. Essas partilhas levaram à pulverização da propriedade escrava na localidade ${ }^{126}$.

Apiaí apresentava um perfil estritamente rural, sem o cultivo de gêneros comercializáveis e com a produção voltada para o autoconsumo ${ }^{127}$. Diferentemente, no Médio e no Baixo Ribeira, a lavoura arrozeira ocupava cada vez mais espaço ao longo do Rio Ribeira e seus afluentes, ampliando a quantidade de grãos exportada. Na década de 1850, foi atingido o auge da quantidade de arroz exportada (100 mil alqueires anuais $)^{128}$. O aumento da produção minimizava os sucessivos déficits da balança comercial verificados, principalmente, a partir da década de 1820, em decorrência da valorização da libra e da consequente elevação do custo dos importados - bens e cativos ${ }^{129}$.

A partir de 1840, o acesso ao mercado de cativos tornou-se mais difícil para os ribeirenses. Tal fato ocorreu devido à elevação do preço do cativo, ao fim do tráfico atlântico e à concorrência com os escravistas das regiões cafeicultoras (Vale do Paraíba e Oeste Paulista), os quais dispunham de mais capital para a compra de escravizados $^{130}$. Assim, na segunda metade do século XIX, o escravismo na região estava em franca decadência, ampliando a quantidade de negros que compunham a parcela da população livre ${ }^{131}$.

A partir da segunda metade do século XIX, a região mergulhou num processo de estagnação econômica, resultante da persistência dos ribeirenses em práticas

\footnotetext{
${ }^{123}$ VALENTIN, 2001, p. 180.

124 Ibid., p.211-212.

125 VALENTIN, 2006, p. 147.

${ }^{126}$ Ibid., p. 251.

${ }^{127}$ VALENTIN, 2001, p. 234.

${ }^{128}$ VALENTIN, 2006, p. 315.

${ }^{129}$ Ibid., p. 31 e p. 49.

${ }^{130}$ Ibid., p. 205.

${ }^{131}$ Ibid., p. 326.
} 
que se revelaram rentáveis apenas durante uma pequena quantidade de anos ${ }^{132}$. Valentim considera a década de 1870 o período final da "belle époque" iguapense ${ }^{133}$. $\mathrm{Na}$ década seguinte, o preço do arroz registrado no Rio de Janeiro teve uma considerável queda, reduzindo ainda mais os ganhos obtidos pelos ribeirenses.

A partir do começo do século $X X$, outras regiões brasileiras, como o Rio Grande do Sul, Goiás, Mato Grosso, Maranhão, o triângulo mineiro e Ribeirão Preto, passaram a produzir arroz em larga escala. Mal abastecida por estradas e com o porto assoreado, a região do Rio Ribeira não fazia mais parte dos centros dinâmicos do Estado ${ }^{134}$.

\footnotetext{
${ }^{132}$ VALENTIN, 2006, p. 247.

${ }^{133}$ Ibid., p. 294.

${ }^{134} \mathrm{O}$ arroz continuou a ser cultivado até fins da década de 1960 , porém, em quantidade pouco significativa. (Ibid., p.15).
} 


\subsection{Rio dos Caminhos}

A possibilidade de navegar nas águas do Rio Ribeira e de seus afluentes atraiu a população às suas margens. Uma das formas de se referir a determinado lugar era informar o nome do rio e a quantidade de dias de viagem necessários para alcançá-lo. No Livro de Tombo de Iguape (1816-1854), foi sublinhado que se atingia o limite da vila após 15 dias de viagem, nas proximidades dos rios Ivaporunduva, Pilões e Iporanga. Em 1857, a Câmara de Xiririca informava ao presidente da Província de São Paulo:

Toda a população deste municipio habita nas margens do Ribeira e nas de muitos rios navegaveis que nelle desaguão, tais como Rio Pardo de 3 dias de viagem, rio Batatal de dia e meio, rio dos Pilões de 3 dias, rio de Pedro Cubas de dois dias, rio Taquary de dia e meio, rio de Xiririca de 1 dia, rio do Etá de 3 dias $^{135}$.

Em vários documentos pesquisados, o Rio Ribeira é retratado como a estrada natural da região. Por exemplo, em 1847, num abaixo-assinado redigido por moradores de Xiririca, consta que o Rio Ribeira era a "[...] única estrada geral de todo o Município" ${ }^{136}$. No mesmo ano, o juiz de Paz de Xiririca informou ao presidente da Província que o Rio Ribeira servia "de estrada franca e favoravel ao comercio de todo o genero" e que a localidade era "independente de estrada de terra" ${ }^{137}$. Os produtos comercializados por caminhos terrestres representavam parcela inexpressiva da quantidade total, e reclamações acerca da qualidade destes caminhos eram recorrentes ${ }^{138}$. Em 1854, o delegado de Xiririca relatou que "[...] a importação de todo este Municipio é feita em canoas pelo Rio denominado da Ribeira que vai desaguar em Iguape"139. As canoas eram itens constantes na maioria dos inventários de xiririquenses e iguapenses ${ }^{140}$, atestando a importância da navegação fluvial para a população local.

\footnotetext{
135 Ofício da Câmara de Xiririca (1852) ao Presidente da Província de São Paulo. Ofícios diversos. Xiririca (ano 1822/1843-1856). Ordem 1339, lata 544. Arquivo do Estado de São Paulo.

${ }_{136}$ Ofícios diversos. Xiririca (1822-1856). Arquivo do Estado de São Paulo.

137 Ofícios diversos. Xiririca (1822-1856). Arquivo do Estado de São Paulo.

${ }^{138}$ VALENTIN, 2006, p. 25.

139 Ofícios diversos. Xiririca (ano 1822/1843-1856). Ordem 1339, lata 544. Arquivo do Estado de São Paulo.

${ }^{140}$ VALENTIN, op. cit., p. 261.
} 
A facilidade de navegação pelo Rio Ribeira foi destacada em alguns documentos. É o caso de um ofício do juiz de paz de Xiririca, redigido em 1847 e endereçado ao presidente da província, no qual foi relatado que a viagem pelo Ribeira era mais vantajosa do que as viagens por estradas terrestres, porque o condutor da canoa era levado ao Porto de Iguape sem fazer esforço, apenas contando com a força das águas, "[...] e só quando volta he que sofre algum trabalho por vir de incontro as agoas, mas como a canoa vem vazia, poco lhe custa"141.

No entanto, possivelmente, essa superioridade dos caminhos fluviais não significava que a navegação era fácil, apenas que as estradas terrestres eram muito precárias. Na documentação consultada, muitas vezes, a travessia fluvial aparece como "penosa", "dispendiosa" e "perigosa". Em 1846, Joaquim de Moura Rolim, morador de Iporanga, nomeado para assumir um cargo em Xiririca (membro da Comissão Inspetora das Aulas públicas e Particulas das Letras de Xiririca), não desejando assumir o cargo, entre outras justificativas, destacou as dificuldades do trajeto pelo Rio Ribeira. Sublinhou que fazia o percurso entre seu sítio em Iporanga e a vila de Xiririca (trajeto de pelo menos 30 léguas) em apenas um dia, devido à "violenta correnteza da Ribeira". No entanto, para retornar, o percurso durava dois dias e meio e a viagem era "muito trabalhosa e perigosa", com fortes corredeiras, fazendo com que corresse o risco de perder a sua vida, assim como a de seus cativos $^{142}$. Por mais que seu interesse em ser exonerado pudesse ter contribuído para que superestimasse os perigos da viagem pelo Rio Ribeira, os riscos deviam ser reais.

Esses aspectos negativos também foram enfatizados em outros documentos. No Livro de Tombo de Xiririca, o pároco relatou que os moradores das Minas de Ivaporunduva estavam descontentes com a necessidade de viajarem, juntamente com seus cativos, até a sede da freguesia de Xiririca na época da desobriga. Além dos prejuízos econômicos decorrentes da ausência dos cativos, "contratempos de uma caudalosa ribeira" navegada por "canoas carregadas de gente de toda a idade" provocavam uma sucessão de "infortúnios", como o afogamento de uma cativa e

\footnotetext{
${ }^{141}$ Ofícios diversos. Xiririca (ano 1822/1843-1856). Ordem 1339, lata 544. Arquivo do Estado de São Paulo.

${ }_{142}$ Ofícios diversos. Xiririca (ano 1822/1843-1856). Ordem 1339, lata 544. Arquivo do Estado de São Paulo.
} 
"[...] outros muito inconvenientes não menos temorosos, que por notorio se não allegas"..$^{143}$

No Livro de Tombo de Iguape, há pedidos, manifestados por moradores de regiões limítrofes, de cumprimento das obrigações religiosas em Iguape. As dificuldades de navegação foram utilizadas como justificativa para os pedidos. Os moradores das regiões limítrofes desejavam o reconhecimento oficial de sua condição de fregueses porque desejavam evitar desavenças com os párocos de suas localidades e se protegerem contra um possível ato de violência por parte das autoridades civis ou religiosas.

João Martins da Silva, residente no rio Juquiá, na divisa entre a Vila de Iguape e a Freguesia de Xiririca, relatou ao Bispo de São Paulo que ninguém queria habitar o citado rio pela dificuldade "que ha dos socorros espirituaes vindos de Xiririca".

[...] grande detrimento e risco de sua alma em ser freguez da Freguezia de Xiririca, não so pela distancia ser maior, doque de Iguape, como tãobem por ser a navegação muito mais custosa, e dificilima, quando vem agôas do monte: que não suceda para Iguape; por ser Ribeira abaixo, eparte della com maré. ${ }^{144}$

Assim, solicitou ao bispo que pudesse cumprir suas obrigações espirituais em Iguape. Seus vizinhos (Bento Lopes, Jose Corrêa, Antonio Garcia, Catharina França, Anna França, Gertrudes Pereira, Felipe Garcia, e Lourenço Fernandes) fizeram o mesmo pedido ao bispo, também frisando que era "muito penoso" transitarem Ribeira acima. Destacaram que era "oneroso" aos párocos de Xiririca prestarem socorros espirituais no rio Juquiá porque tinham que navegar contra a maré. Situação diversa aconteceria se fossem fregueses de Iguape, pois navegariam a favor do rio. Em 1813, o Bispo de São Paulo deferiu todos os pedidos.

Manuel Jose de Lima, morador no Porto do Una, pertencente à Vila de Conceição de Itanhaém, explicou ao bispo de São Paulo que nunca prestou obediência ao pároco de Itanhaém. Possuía propriedades na Vila de Iguape, onde cumpria suas obrigações espirituais "por lhe ser mais facil o transporte pela

\footnotetext{
${ }^{143}$ Livro de Tombo de Xiririca (1813-1898). Paróquia de Eldorado (SP).

${ }^{144}$ Livro de Tombo de Iguape (1816-1854). Paróquia de Iguape (SP).
} 
navegação do Rio" ${ }^{145}$. Solicitou continuar sendo freguês da Vila de Iguape, o que foi concedido pelo bispo.

O pároco de Iguape também destacou as melhorias implantadas, frisando que, num período anterior, a navegação pelo Ribeira era mais "[...] custoza, o que hoje se tem facilidade, e abreviado pelos muitos fúrados, ou canaes, que se tem aberto" ${ }^{146}$. Mesmo com os avanços, as travessias fluviais ainda representavam riscos, maiores ou menores "segundo o estado de cheias ou de secas dos ditos rios" $^{147}$, não admitindo trânsito em algumas ocasiões.

Riscos e dificuldades maiores envolviam travessias fluviais cuja finalidade era a condução de mortos para o local do sepultamento. Moradores da Praia da Juréia sepultavam os mortos numa pequena capela edificada em louvor a Nossa Senhora de Guadalupe (localizada na Praia da Juréia) ${ }^{148}$. Diferentemente dos sepultamentos na Vila, eram "privados de todos os sufragios", não eram "recomendados", não recebiam nem "ao menos huma Missa" e não era feito o termo de óbito ${ }^{149}$. Na década de 40 do século XIX, os moradores da região solicitaram ao bispo a "[...] conceção de hum Cemiterio naquelle lugar para bem de serem sepultados em hum lugar sagrado" 150 .

Poucos anos depois, quando o decreto 798 de 18 de junho de 1851 foi instituído, determinando a obrigatoriedade do registro de óbito, muitas dúvidas surgiram na Vila de Xiririca. O decreto definia que o sepultamento só ocorreria após o registro de óbito, o qual só era realizado na sede da vila. As autoridades locais não sabiam como proceder nos casos em que as pessoas falecidas eram provenientes de locais distantes, pois causariam muitos inconvenientes submeter o cadáver a uma longa espera. Em 1852, o juiz de paz da Vila de Xiririca informou ao Presidente da Província de São Paulo que "[...] dentro do Districto d'esta Villa porem retirado della a quasi dous dias de viagem, no lugar denominado Ivaporunduva [...]" morava um povo "bastante pobre". Os mortos eram enterrados na "Capela de Nossa

\footnotetext{
${ }^{145}$ Livro de Tombo de Iguape (1816-1854). Paróquia de Iguape (SP).

${ }^{146}$ Livro de Tombo de Iguape (1816-1854). Paróquia de Iguape (SP).

147 Ofícios diversos. Xiririca (ano 1822/1843-1856). Ordem 1339, lata 544. Arquivo do Estado de São Paulo.

${ }^{148}$ Os sepultamentos nesta capela foram abordados no Capítulo 5 (item 5.3.2, Capela de Guadalupe).

${ }^{149}$ Livro de Tombo de Iguape (1816-1854). Paróquia de Iguape.

${ }^{150}$ Livro de Tombo de Iguape (1816-1854). Paróquia de Iguape.
} 
Senhora do Rozario". Relatou que as autoridades locais não estavam exigindo o registro de óbito porque, se fosse exigido, "seria com pezado trabalho e até inútil". Questionou: "[...] durante três dias de viagem de vinda e ida, deixarião o cadaver exposto a putrefação". Desse modo, o juiz de paz pedia para ser orientado sobre os procedimentos adequados nesses casos ${ }^{151}$.

O juiz de paz de Xiririca também queria ser orientado sobre o procedimento correto nos casos em que os fazendeiros preocupavam-se em cumprir o decreto, mas não se preocupavam com as suas consequências. Relatou a existência de casos em que um cativo ou alguma outra pessoa falecia e o cadáver era conduzido até a vila por um escravizado que não levava nada por escrito. Assim, não era possível fazer o registro de óbito e o pároco não providenciava a sepultura. $O$ cativo não sabia o que fazer, assim como o juiz de paz. Abaixo, o questionamento do juiz de paz ao presidente da Província:

[...] alguns fazendeiros ou outras pessoas moradoras em logares distantes desta Villa de um a dois dias de viagem quando lhes morre um seo escravo, ou outro qualquer mandão o cadaver a esta Villa para enterrar-se somente acompanhado d'um escravo, sem ser uma pessoa que faça a preciza participação, ou sem a mandarem por escripta para se poder fazer o registro e desta forma não posso passar a certidão e o Parocho sem esta não da a sepultura, ficando o pobre do escravo com o cadáver indecizo, sem saber o que faça, porque para ir ter com seu ammo lhe levaria 2 a quatro dias de viagem de ida e volta, tempo que o cadaver ja não é possivel esperar sem corromper-se; por conseguinte resta-me agora perguntar a V.E. o que deveria proceder neste cazo, e se o mesmo escravo pode fazer a participação quando esteja de tudo o fato e se igualmente deve assignar o mesmo ${ }^{152}$.

Se trafegar pelo Rio Ribeira envolvia perigos reais e momentos de incerteza e tensão, ser impedido de percorrê-lo provocava mais tensão ainda. Esse foi o caso dos vizinhos de Jose Joaquim de Assumpção, que moravam num lugar mais retirado e precisavam percorrer uma estrada de terra para chegar ao Ribeira. Essa estrada passava pelas terras de José Joaquim, o qual, "intrigando-se com seus vizinhos, não quis mais que the passassem pelo seu terreiro, para cujo fim fez hum desvio". A obstrução da estrada impediu que seus vizinhos chegassem ao rio, mas eles desbloquearam o caminho para superar o isolamento a que foram submetidos.

\footnotetext{
${ }^{151}$ Manuscritos e ofícios diversos. Xiririca (ano 1822 / 1843-1856). Ordem 1339, Lata 544. Arquivo do Estado de São Paulo.

${ }_{152}$ Manuscritos e ofícios diversos. Xiririca (ano 1822 / 1843-1856). Ordem 1339, Lata 544. Arquivo do Estado de São Paulo.
} 
Isso fez com que fossem presos; e o embate entre José Joaquim e seus vizinhos reverberou na sede da vila. A Câmara manifestou-se favoravelmente a José Joaquim, enquanto o juiz de paz defendeu os vizinhos. Destacou que eles foram "castigados com prizão, e sem as formalidades da lei" e que "por serem todos huns mizeraveis sofrem em silêncio a injustiça". Por fim, concluiu: "ou a Câmara perdeu o juízo, ou nunca o teve"153.

Dominar o tráfego pelo Rio Ribeira e pelo mar era a chave do poder do segmento mais abastado da sociedade ribeirense, os comerciantes. Ao dominar as águas, rompiam o isolamento e garantiam o trânsito de pessoas e mercadorias. Além da existência de um porto de mar, a fixação de comerciantes na Vila de Iguape foi favorecida pela presença de estaleiros na região ${ }^{154}$. Os primeiros foram instalados no começo do século XVIII. Em 1711, a primeira obra naval, construída nas cercanias de Cananéia, foi lançada ao $\operatorname{mar}^{155}$. Foram construídas embarcações entre, aproximadamente, os anos de 1711 e $1834^{156}$. Em fins do século XVIII, existiam seis estaleiros em Iguape, e seis em Cananéia ${ }^{157}$. Em 1801, 19\% dos fogos iguapenses eram compostos por madereiros, lenhadores, calafates, canoeiros e carpinteiros, os quais absorviam $16 \%$ dos cativos ${ }^{158}$. No entanto, em 1836, os sinais de estagnação econômica dessa atividade podiam ser notados pela reduzida quantidade de escravizados - existiam 19 carpinteiros sem cativos e apenas 10 escravizados, pertencentes a três carpinteiros ${ }^{159}$.

Os comerciantes utilizavam as embarcações para escoar a produção agrícola da região e para fornecer mercadorias e cativos à população. Entre os grandes comerciantes do começo do século XIX, José Antonio Peniche merece destaque. Português, natural da freguesia de Peniche, pertencente ao distrito de Leiria, tradicional região portuguesa de construção de embarcações, em 1789, tinha 29

\footnotetext{
${ }^{153}$ Oficios diversos. Xiririca (1822-1856). Ordem 1339, Caixa 544. Arquivo do Estado de São Paulo.

${ }^{154}$ VALENTIN, 2006, p. 287.

155 ALMEIDA, 1963, p. 11.

${ }^{156}$ Ibid., p. 18.

157 CALIXTO, Benedito. Capitania de Itanhaen. Revista do Instituto Histórico e Geográfico de São Paulo, São Paulo, v. XX, 1915, p. 685.

${ }^{158} \mathrm{O}$ começo da lavoura do arroz estava associado com a presença destes construtores de embarcações do final do século XVIII. Parcela de escravistas e escravizados que, previamente, dedicavam-se à construção de embarcações migraram para a rizicultura. (VALENTIN, 2006, p. 132 e 314).

${ }^{159}$ Ibid., p. 314.
} 
anos, possuía 8 cativos e já morava em Iguape. Em 1801, tinha 40 anos e dedicavase à construção de embarcações. Detinha a posse de 31 cativos, os quais possuíam diversas especializações, tais como carpinteiros, calafates, ferreiros e marinheiros. Também era comerciante e produtor de arroz. Em 1828, aos 62 anos, detinha a segunda maior posse de cativos em Iguape e Xiririca, a qual somava 62 escravos. José Antonio foi capitão-mor da Vila de Iguape e recebeu o título de cavaleiro professo da Ordem de Cristo ${ }^{160}$. Seu filho, Antonio José Peniche, assumiu os negócios iniciados pelo pai, dedicando-se à rizicultura, ao comércio e à construção de embarcações ${ }^{161}$. No começo do século XIX, pai e filho foram responsáveis por $16 \%$ das mercadorias que entraram no porto de Iguape, sendo a maioria delas era proveniente do porto do Rio de Janeiro, o qual também era o principal destino da produção da região, além de exercer o monopólio do fornecimento de escravizados $^{162}$. O mercado de cativos em Iguape, no começo do século XIX, era dominado pelo Capitão-mor José Antonio Peniche e por seu filho, Antonio José.

Outros representantes do segmento mais abastado da sociedade iguapense também possuíam embarcações. Em 1801, o comerciante português Vitorino José Franco possuía loja de fazendas secas e um navio que realizava viagens frequentes ao porto do Rio de Janeiro ${ }^{163}$. Vitorino José também ocupou um posto público e foi juiz ordinário na Vila de Iguape ${ }^{164}$. Algumas décadas depois, seu filho, João Mancio da Silva Franco, juntamente com Antonio Jose Peniche, foi proprietário de um brigue. João Mancio também adquiriu outras embarcações como mais um brigue e três patachos ${ }^{165}$ e, assim como seu pai, foi um grande comerciante.

Outro proprietário de embarcações que alcançou grande prestígio na sociedade iguapense, em meados do século XIX, foi José Jacinto Toledo ${ }^{166}$. Possuía

\footnotetext{
${ }^{160}$ Manuscritos e Ofícios Diversos. Iguape (1818-1831). Caixa 243, Ordem 1038. Arquivo do Estado de São Paulo.

${ }_{161}^{16}$ VALENTIN, op. cit., p. 286.

${ }^{162}$ Ibid., p. 31.

${ }^{163}$ VALENTIN, 2006, p. 292.

164 Manuscritos e Ofícios diversos. Recife, Xiririca, Bragança, S. Bernardo, P. Feliz, Montevideo, Cananéia, Paranaíba, M. Grosso, S. Carlos, Rio de Janeiro, S. Sebastião, Itapetininga (1801-1818). Caixa 101, Ordem 351, Pasta 6. Arquivo do Estado de São Paulo.

${ }_{165}$ VALENTIN, op. cit., p. 293.

166 João Mâncio casou-se com uma das filhas de José Jacinto. Após enviuvar, casou-se com uma outra filha de José Jacinto. Assim, João Mancio herdou grande parte da fortuna do sogro. Na década de 70, quando a crise da cultura arrozeira acentuou-se, João Mâncio se transferiu para o Rio de Janeiro. Desse modo, drenou parcela da sua fortuna para a corte carioca. Juntamente com o Barão
} 
duas sumacas, dois patachos e um brigue, os quais the garantiam acesso à praça mercantil do Rio de Janeiro. Além de comerciante, José Jacinto possuía engenho de arroz. Ocupou postos no Exército - tinha patente de tenente coronel - e chefiou tropas da Guarda Nacional em Iguape. Também foi delegado de polícia e atuou na política. Foi vereador e, num momento posterior, deputado provincial. Foi agraciado com o título de comendador ${ }^{167}$.

Ricos comerciantes, como o capitão Peniche, José Jacinto Toledo e João Mâncio, também se dedicaram à rizicultura. Unindo comércio e lavoura, construíram grandes fortunas. Também atuaram na vida pública e, assim, concentraram poder político. Ao dominar as águas do rio e do mar, dominavam a sociedade ribeirense.

O produtor precisava pilar, ensacar e transportar a produção de arroz. Os comerciantes financiavam todas essas etapas do processo produtivo e encarregavam-se de fazer o produto chegar ao porto de Iguape e, depois, seguir para o porto do Rio de Janeiro. Um receptor no Rio de Janeiro realizava a venda. Só depois, as custas do processamento dos grãos, ensacamento e transporte eram saldadas pelo produtor ${ }^{168}$. Os credores eram os remetentes de arroz, o que fez com que se expandisse a rede de crédito em Iporanga, Xiririca e Iguape. Como os comerciantes também forneciam bens de consumo e cativos, o saldo devedor dos produtores poderia ser ainda maior. Ao controlar o fornecimento de crédito, o fluxo de exportação e a entrada de cativos, os grandes comerciantes dominavam toda a cadeia produtiva.

Mesmo pequenos produtores de arroz contraíam débitos. Por exemplo, uma quantidade enorme de produtores de arroz devia aos comerciantes Miguel Antonio Jorge (Xiririca) e João Mâncio da Silva Franco (Iguape), porém, deve-se notar que, na maior parte dos registros, o débito por produtor era modesto ${ }^{169}$. Esse era o caso dos créditos cedidos pelo napolitano Rafael Descio. Estabelecido em Iporanga no início da década de 1830 e falecido em 1865, a abertura do seu inventário revelou

do Flamengo (Luis de Matos Pereira e Castro) assumiu, em 1889, o controle do Banco Comercial do Rio de Janeiro. (Ibid., p. 64).

167 Ibid., p. 290.

${ }^{168}$ VALENTIN, 2006. p. 242-243.

${ }^{169}$ Ibid., p. 241. 
que havia concedido crédito a 754 moradores da região ${ }^{170}$.

Os riscos de o produtor não saldar a dívida eram elevados. Carlos Rath sublinhou os casos de inadimplência decorrentes das inundações frequentes, da presença de animais e insetos prejudiciais aos arrozais e da perda da capacidade produtiva e morte de cativos:

A cultura do arroz além de não produzir grandes lucros é sujeita a muitas eventualidades, uma só das quais realizando-se bastante para fazer perder todas as despesas e trabalhos de plantação; tais são às vezes as extraordinárias enchentes da Ribeira e de outros rios caudalosos em uns anos. As chuvas excessivas nos tempos das derrubadas, queimadas ou colheitas, os milhões de ratos que aparecendo repentinamente, tudo destroem, os pássaros, periquitons, guarúnas, pombas, pixoxós que aparecem em quantidade extraordinárias, as lagartas que chamam Coruquerés são outras pragas que a perseguem. Admiro como estes pássaros, especialmente os Pixoxós que comem, até de noite, destroem e arrasam, ajudados pelos Coruqueres e ratos, arrozais inúmeros de uma noite para o dia. Acresce que esta cultura, no Distrito de lguape, onde é feita somente nos terrenos charcosos, é sobremaneira prejudicial e fatal à saúde dos trabalhadores, especialmente dos escravos ${ }^{171}$.

A região do Rio Ribeira era, frequentemente, assolada por fortes cheias. $O$ pároco de Xiririca questionou:

[...] se os mais pequenos regatos se elevam e sobrepujão prodigiosamente com a abundância das chuvas, um rio grande, cujas águas são o concurso de muitos rios, que se associam e ajuntam em um só madre como acontece com esta ribeira, a que vão de elevação deve subir até que se possa esvaziar ${ }^{172}$.

Há registro de ocorrência de várias enchentes avassaladoras, como a de 1807, a qual destruiu os arrozais de Xiririca ${ }^{173}$. "Cheias extraordinárias" ocorreram também em 1809, 1826 e $1833^{174}$. Isso sem contar as inúmeras cheias ordinárias, sendo que "[...] para exceder os limites das cheias ordinárias este caudaloso rio, não carece mais que as chuvas abundem mais da parte dos campos e das suas cabeceiras, para subir aos lugares mais altos, e alagar tudo em distância imensa"175.

\footnotetext{
${ }^{170}$ Ibid., p. 239.

${ }_{171}^{171}$ RATH, 1856, p. 55.

${ }_{173}^{172}$ Segunda Pasta, Freguesia de Xiririca. Cúria Metropolitana.

${ }^{173}$ Informação contida na ata de Câmara da Vila de Iguape da sessão realizada no dia $1^{\circ}$ de janeiro de 1807 - documento publicado por Paulino de Almeida. (ALMEIDA, 1852, p. 29).

${ }_{174}^{174}$ Segunda Pasta, Freguesia de Xiririca. Cúria Metropolitana.

${ }^{175}$ Segunda Pasta, Freguesia de Xiririca. Cúria Metropolitana.
} 
O pároco de Xiririca fez o seguinte relato da enchente de 1809:

Que triste era andar em canoas, carregadas com os móveis domésticos,
procurando refúgio contra as aguas que cresciam e inundavam, e quando
parecia escapar-se em uma casa por estar em mais alto terreno, onde não
contava ter chegado água das cheias anteriores. Passar logo a outra casa
mais alta e desta enfim procurar como último asilo a mesma Igreja, reduzida
a necessidade de fazer-se desta casa sagrada o --- ou comum depósito das
coisas profanas, como aconteceu então, e pode acontecer ainda.

Depois disto, que desconsolação ver submergidas, e algumas destroçadas inteiramente depois da inundação aquelas casas que faziam o ornato da freguesia a residencia dos moradores, dando um espetaculo lastimoso já nos parecem sem beleza com esqueletos descamados e entulhados. De profunto lodo, já por estarem inclinadas e prensas, destituídas de portas, de janelas, dos moveis, enfim de madeira do uso interior, e que guardavam a alfaya domestica e a roupa dos habitantes porque tudo as aguas arrebatavam com os mais despojos sujeitos a sua violencia elevação e espalhar ao longo, e por diversas e incognitas partes! ${ }^{176}$

As enchentes fizeram com que a sede de Xiririca fosse transferida para um novo local - o porto Formosa - uma colina situada a jusante da antiga matriz. Em 1816, tiveram princípio as obras da nova matriz.

As cheias aumentavam a vulnerabilidade dos lavradores, ampliando, consequentemente, a sua dependência em relação aos seus credores. Como consumidores, eles também eram dependentes dos credores, os quais cobravam preços elevados pelos produtos que comercializavam. Em 1845, o diretor da Mesa de Rendas de Iguape, José Inocêncio Alves Alvim, criticou a exorbitância dos preços e destacou que os lavradores, caso "[...] tenham a fortuna de ter uma boa safra de arroz, todo seu produto se Ihes vai em despesas". No entanto, ressaltou que "se por desgraça falha a safra", contraíam dívidas com os negociantes, com juros proporcionais ao "[...] maior ou menor grau de cobiça e dureza de coração daqueles que então ditam a lei aos necessitados". Como resultado, os lavradores caíam "[...] em um abismo de que jamais se podem levantar, ficam por toda a sua vida cativos dos negociantes [...]. Tal é, sem exageração, o desgraçado estado e deplorável sorte de quase todos os lavradores de Iguape e Xiririca"177.

Carlos Rath também destacou a relação entre donos de embarcações, domínio das águas, endividamento e monopólio da oferta de produtos e do

\footnotetext{
${ }^{176}$ Segunda Pasta, Freguesia de Xiririca. Cúria Metropolitana.

${ }^{177}$ ALVIM apud VALENTIN, 2006, p. 77.
} 
escoamento da produção: "O povo inteiro vê-se obrigado a entregar todo o seu negócio nas mãos de uma duzia de donos de embarcações, e de alguns outros uzurarios que fazem o mercado deste lugar"178. Tal fato possibilitava aos comerciantes ditar os preços. Essa situação ocorria porque "[...] a unica via transitavel em toda a região da Ribeira, são até hoje as aguas da mesma, e seus tributarios". Por ter apenas uma via de saída, Carlos Rath classificou a região como isolada e de difícil acesso e defendeu a necessidade da construção de estradas. Relatou que os caminhos terrestres existentes eram as trilhas antigas dos "lavradores de ouro, dos caçadores, dos foragidos e criminosos", sublinhando que ficavam inundadas na maior parte do ano. Afirmou que terceiros tinham recebido verbas do governo para construírem estradas, porém, agiram como "espertos especuladores". Os recursos foram desperdiçados e as obras foram pessimamente executadas $^{179}$.

As mudanças mais significativas realizadas ao longo do século XIX não estavam associadas aos caminhos terrestres, mas sim aos caminhos fluviais. Até meados do século XIX, brigues e iates monopolizavam o transporte de cargas entre Iguape e o Rio de Janeiro. Em 1853, vapores foram introduzidos e passaram a realizar a rota entre o Rio de Janeiro e os portos do Sul ${ }^{180}$. Porém, a mudança mais aguardada foi a construção de um canal chamado Valo Grande.

Desde 1799, agricultores do interior defendiam a abertura de um canal de ligação entre o Rio Ribeira de Iguape e o Mar Pequeno. Esse canal encurtaria a distância até o porto de Iguape e, por isso, foi visto como uma obra muito benéfica para a região. As obras foram iniciadas em 1827 e o canal, chamado Valo Grande, foi inaugurado em 1837. No entanto, não tardou para que a população da região mudasse de opinião e os efeitos deletérios da abertura do canal viessem à tona. A força vertiginosa das águas fez com que, gradativamente, as margens desmoronassem e a abertura do canal se ampliasse. Inaugurada com 2 metros de largura e poucos palmos de profundida, a abertura do canal chegou a quase 300 metros de largura e 19 metros de profundidade. Ao longo dos anos, o material proveniente do solapamento das margens do Rio Ribeira foi sendo depositado,

\footnotetext{
${ }^{178}$ RATH, 1856, p. 14.

179 lbid. , p. 14.

${ }^{180}$ VALENTIN, 2006, p. 42.
} 
provocando o entulhamento do ancoradouro dos navios. A partir de 1876, não era mais possível que navios de grande porte ancorassem no porto de lguape ${ }^{181}$. Assim, se antes a região do Rio Ribeira era isolada porque só possuía uma saída, com o assoreamento do ancoradouro, a situação agravou-se consideravelmente.

Economicamente apoiada na rizicultura e logisticamente apoiada no porto de Iguape, no final do século XIX, a região do Rio Ribeira perdeu duplamente. $E$ isso numa província próspera graças, principalmente, ao café, e que modernizava seus meios de transporte com a introdução de ferrovias. Assim, eram notáveis os contrastes entre a isolada região do Rio Ribeira e o restante do Estado de São Paulo, os quais se evidenciaram ao longo do século $\mathrm{XX}$.

\subsubsection{Rios e chamas: o caso Caiacanga}

Entre os mais ricos comerciantes do século XIX, Miguel Antonio Jorge merece destaque. Residente em Xiririca, o português Miguel Antonio Jorge foi o maior exportador de arroz de toda a região do Rio Ribeira e, por isso, foi considerado por Agnaldo Valentin o "rei do arroz"182. Miguel Antonio Jorge destinou grande parte dos seus ganhos à compra de terras localizadas em Iguape e Xiririca. Foi o maior comprador de terras de Xiririca. Em 1845, do total de recursos arrecadados, referentes a transações envolvendo bens de raiz (sisas) em Xiririca, a maior parte foi paga por Miguel Antonio Jorge ${ }^{183}$. Nesse ano, pagou sisa referente à compra de duas propriedade rurais, uma "na paragem denominada Caiacanga" e outra "no rio dos Abobraes"184. Entre 1849 e 1879 , realizou 100 compras $^{185}$. Acumulou o estoque

\footnotetext{
181 PAES, Gabriela Segarra Martins. A Recomendação das Almas na Comunidade Remanescente de Quilombo de Pedro Cubas. 2007. Dissertação (Mestrado em História) - Faculdade de Filosofia, Letras e Ciências Humanas da Universidade de São Paulo, São Paulo, 2007, p. 29-31.

${ }^{182}$ VALENTIN, 2006, p. 64.

${ }^{183}$ Sisas 1810-1853. Iguape. C08414. Arquivo do Estado de São Paulo.

${ }^{184}$ Sisas 1810-1853. Iguape. C08414. Arquivo do Estado de São Paulo.

${ }^{185}$ VALENTIN, op. cit., p. 64.
} 
de bens rurais mais expressivo da região do Rio Ribeira ${ }^{186}$.

Ao longo da vida, além de terras, acumulou cativos. Em 1828, tinha 24 anos e dois cativos. Em 1836, era proprietário de 13 cativos $^{187}$. Em 1852, possuía 61 escravizados na sua principal propriedade rural, a fazenda Caiacanga ${ }^{188}$. Em 1854, o juiz municipal de Xiririca relatou ao presidente da Província que "[...] na sua fazenda Caiacanga, coito de quantos criminozos há nesta cidade, daquella vila e de Serra Acima tem com os seus escravos para mais de 300 pessoas" ${ }^{189}$. Embora possuísse uma quantidade vultosa de cativos, trezentos parece um número superestimado. A afirmação do juiz de paz aponta para outro fato recorrente: o acúmulo de inimizades que Miguel Antonio conquistou ao longo da vida. Entrou em atrito com moradores próximos do rio Capinzal porque represou num tanque as águas de várias vertentes que desaguavam nesse rio (subafluente do Rio Ribeira), impedindo que os residentes nele navegassem. As águas armazenadas geravam energia para a movimentação de três engenhos de Miguel Antônio Jorge, sendo dois engenhos de arroz e um de cana. Principalmente no período da seca, essas águas faziam falta e o rio ficava intransitável, isolando os moradores. Miguel Antonio Jorge pretendia desviar as águas de mais um ribeirão e iniciou as obras necessárias. Os moradores do rio Capinzal, receando que as águas baixassem e, consequentemente, fosse impossibilitada a navegação, abriram o tanque de Miguel Antonio e fizeram com que secasse. Afirmaram que "[...] quantas vezes Miguel Antonio Jorge encanar a água, quantas vezes irão abrir por conta da falta que ela faz"190.

Miguel Antonio Jorge confrontou-se com representantes de vários segmentos da sociedade, inclusive com representantes da elite local ${ }^{191}$. Foi processado pelo Comendador Luis Alvares da Silva, proprietário de engenho de arroz e um dos mais ricos comerciantes de Iguape, sob a acusação de ter acoitado um cativo e de ter sido o responsável pelo assassinato do homem contratado para resgatar o

\footnotetext{
${ }^{186}$ Ibid., p. 118.

${ }^{187}$ Ibid., p. 64.

${ }^{188}$ Ibid., p. 118.

189 Manuscritos e Ofícios Diversos. Xiririca (ano 1822 /1843-1856). Ordem 1339, Lata 544. Arquivo do Estado de São Paulo.

${ }^{190}$ Ofí́cios Diversos. Ordem 1044. Arquivo do Estado de São Paulo.

${ }^{191}$ Museu Histórico e Arqueológico de Iguape. Caixas 223, 224 e 235.
} 
fugitivo ${ }^{192}$.

Miguel Antonio Jorge também ocupou postos públicos. Entre outros cargos, foi delegado de polícia em Xiririca, recaindo-lhe a responsabilidade de recrutar soldados. Isto fez com que seu leque de desafetos crescesse. No dia 25 de janeiro de 1865, relatou ao presidente da Província:

\begin{abstract}
Encarregando-me Vossa Excelencia da ardua tarefa de organizar o maior numero possivel de recrutas para o Exercito e Marinha. Conquanto este cargo seja o mais arduo e espinhoso que ha para as autoridades locaes, assim mesmo posso afiançar á Vossa Excelencia que vou empregar todos os meios ao meo alcance para o bom desempenho da missão ${ }^{193}$.
\end{abstract}

Esta não foi a primeira vez que Miguel Antonio Jorge ficou responsável pelo recrutamento. Em anos anteriores, também como delegado, dedicou-se a essa tarefa. Empenhou-se em desmentir os homens que, conforme seu julgamento, fingiam ser casados apenas para evitar o recrutamento. Foi o caso de João Miguel Pascoal. Em 1859, Miguel Antonio Jorge relatou ao presidente da Província que a suposta mulher de João Miguel Pascoal foi "procurada e seduzida pela mãe do recrutado" e que tentaria "iludir a Vossa Excelência"194. Um impasse sério ocorrera seis anos antes. Em 1853, o presidente da Província ordenara que Miguel Antonio Jorge relaxasse a prisão de Francisco Rodrigues de Freitas e Francisco Antonio Pereira, porque o alistamento tinha ocorrido num período em que o recrutamento já estava suspenso. Miguel Antonio não cumprira a ordem e fora repreendido. Em sua defesa, Miguel Antonio Jorge afirmara que não teve a intenção da transgredir as ordens do presidente da província e que não tinha recebido o ofício que comunicava a suspensão do recrutamento. Disse: "[...] para este Municipio não há correio, chegão os officios a lguape alli demorão humas vezes por falta de portadores ${ }^{195}$,

\footnotetext{
192 Outras desavenças relacionadas ao Comendador Luis Alvares da Silva foram abordadas no capítulo 5 (item 5.1 - Irmandades e Igrejas de Iguape) e no capítulo 7 (item 7.2 - "Curadores de Feitiço" em Iguape).

${ }^{193}$ Manuscritos e Ofícios Diversos. Xiririca (1857 - 1891). Ordem 130, Lata 545. Arquivo do Estado de São Paulo.

${ }^{194}$ Manuscritos e Ofícios Diversos. Xiririca (1857 - 1891). Ordem 130, Lata 545. Arquivo do Estado de São Paulo.

${ }^{195}$ Num ofício do ano seguinte, o delegado de Xiririca, Zeferino Jorge Damasceno, informava ao presidente da Província que a Vila de Iguape distava 40 léguas de Xiririca. Relatou que a "penosa" viagem até a Vila de Iguape era feita pelo Rio Ribeira e que "escravos e pessoas da classe mais baixa, são justamente estes que conduzem todos os papéis, offícios, e como o fazem sem responsabilidade continuamente se estão descaminhando cartas, offícios e outras couzas
} 
outras vezes porque alguém tem interesse em demoral-os para comprometer". Questionou:

[...] e de mais, Excelencia, que interesse tinha eu em transgredir a ordem de V.E.? Seria para vingar-me de um mizerável filho de uma meretriz escandaloza, e que não vevia em companhia de sua mãe, e de maus costumes? Ou para vingar-me de hum vagabundo que a dez annos anda neste municipio sem achar hum pedaço de terra que the agrade para se situar? Não foi nada disso, foi o que já expendi a V. E. não ter eu recebido a mencionada ordem.

Tenho cumprido quanto me tem sido possivel as ordens de V. E. e dos seos antecessores, não posso porem sujeitar-me á vontade de alguns homens de Iguape, por isso rogo a V.E. se sirva conceder-me a demissão de Delegado de Polícia, o que confiadamente espero. Oxalá que eu pudera obter mais a demissão de Eleitor, Membro da Camara Municipal e de terceiro Suplente de Juiz Municipal e de Órfãos ${ }^{196}$.

O ofício demonstra que Miguel Antônio Jorge não se esquivava de uma situação conflituosa. Dedicou-se com afinco em arregimentar homens e confrontouse com as autoridades de Iguape. Também indica que ele acumulava postos públicos e estava, de alguma forma, inserido no grupo que dava as ordens. Permaneceria mais um ano no posto de delegado. Nesse meio tempo, entrou em choque com uma autoridade de Xiririca, o juiz de paz. Num ofício endereçado ao presidente da Província, o juiz de paz enfatizou o poder desmedido de Miguel Antonio Jorge, o qual dispunha "[...] de tudo neste lugar sem haver quem dos seus actos seja capaz de tomar conta". Relatou a necessidade e a dificuldade de realizar uma diligência na fazenda Caiacanga, onde Miguel Antonio vivia com mais de 300 cativos, por "[...] ser distante desta cidade cerca de 5 legoas e o transporte faz-se em pequenas canoas"197. Miguel Antonio Jorge acabou perdendo o posto de delegado e assumiu o posto de Administrador da Estrada de Paranapanema. Porém, no dia 25 de dezembro de 1858, retornou ao cargo de delegado ${ }^{198}$.

d'importancia que importa grande prejuízo aos habitantes". Esse ofício aponta para a importância dos escravizados na condução de documentos pelo Rio Ribeira. Também sugere que a condução da travessia fluvial por escravizados podia ser utilizada para justificar o descumprimento de uma ordem, alegando o não recebimento da mesma. Manuscritos e Ofícios Diversos. Xiririca (ano 1822 / 18431856). Ordem 1339, Lata 544. Arquivo do Estado de São Paulo.Rio RibeiraRio Ribeira

${ }^{196}$ Manuscritos e Ofícios Diversos. Xiririca (ano 1822/ 1843-1856). Ordem: 1339, Lata: 544. Arquivo do Estado de São Paulo.

${ }^{197}$ Manuscritos e Ofícios Diversos. Xiririca (ano 1822/ 1843-1856). Ordem 1339, Lata 544. Arquivo do Estado de São Paulo.

${ }^{198}$ Manuscritos e Ofícios diversos. Xiririca (ano 1857-1891). Ordem 130, Lata 545. Arquivo do Estado de São Paulo. 
Em 1854, o juiz de paz também descreveu Miguel Antonio Jorge como o "negociante mais forte de Xiririca"199. Miguel Antonio fornecia crédito aos produtores de arroz e encarregava-se de escoar a produção. Devido à distância em relação ao Porto de Iguape, os produtores de Xiririca, em comparação com os iguapenses, estavam numa situação mais difícil. Poucos comerciantes possuíam capacidade efetiva de manter o escoamento do arroz num fluxo adequado. Dentre esses poucos, Miguel Antonio Jorge destacava-se.

Como produtor e comerciante, esse negociante amealhou um excepcional poder econômico. Inserido em postos públicos, também concentrou poder político. Usou e abusou do seu poder. Confrontou-se com os moradores do rio Capinzal, com membros do poder local e até mesmo desrespeitou ordens do presidente da Província. Seu empenho em arregimentar homens contribuiu ainda mais para a sua impopularidade. Em Eldorado, antiga Xiririca, nos dias atuais, Miguel Antonio Jorge ainda é lembrado. Sua riqueza e seu poder são vistos como decorrentes de um pacto firmado com o diabo. É lembrado pela sua crueldade, especialmente contra seus cativos. Moradores das comunidades negras da região, principalmente das Comunidades Remanescentes de Quilombo de Pedro Cubas e de Abobral ${ }^{200}$, relatam que muitos dos seus antepassados fugiram de Caiacanga ${ }^{201}$.

Caiacanga situava-se na margem direita do Rio Ribeira, $10 \mathrm{~km}$ abaixo do núcleo urbano de Xiririca. Os numerosos cativos plantavam arroz, cana, algodão mandioca e café e eram responsáveis pelo trabalho nos dois engenhos de arroz, em um de cana e na pequena serralheria ${ }^{202}$. Trabalho árduo e castigos frequentes faziam parte do cotidiano da localidade. Isso contribuiu para que Caiacanga, nos dias atuais, seja associada a infortúnios e sofrimentos. Seu desventuroso fim também deve ter colaborado para essa visão.

No dia 10 de fevereiro de 1878, a sede de Caiacanga explodiu ${ }^{203}$. O juiz de

\footnotetext{
${ }^{199}$ Manuscritos e Ofícios Diversos. Xiririca (ano 1822/ 1843-1856). Ordem 1339, Lata: 544. Arquivo do Estado de São Paulo.

${ }^{200}$ A comunidade negra do Abobral foi apontada como quilombola, mas ainda não foi reconhecida oficialmente.

${ }^{201}$ Miguel Antonio Jorge possuía terras, conforme anotado no Registro de Terras de Xiririca, nas seguintes localidades: em Caiacanga, Pedro Cubas, Jaguary, Ribeirão Batatal, Batatal, Barra do Abobral, Porto de Formosa e Areado.

${ }^{202}$ VALENTIN, 2006, p. 117.

${ }^{203}$ Manuscritos e Ofícios Diversos. Xiririca. Ordem 4823, Lata 78. Arquivo do Estado de São Paulo.
} 
Direito de Xiririca relatou ao presidente da Província os fatos ocorridos. A sede de compunha-se de três pavimentos. No térreo e no primeiro andar, ficavam as máquinas, as oficinas e o depósito de diversos produtos, inclusive de bebidas alcoólicas. O último andar servia de moradia para o proprietário e sua família. Às 19h, Jose Carvalhido, sobrinho de Miguel Antonio Jorge, ao transferir a aguardente (genebra) contida em alguns garrafões para uma pipa,

[...] irreflectidamente tirou de dentro de uma lanterna uma luz que inflamando o alcohol que continha um dos garrafões, produzio rapida explosão que communicando-se a mais 14 pipas de aguardente, que se achavão depositadas no pavimento terreo, deo lugar á uma rapida e horrorosa detonação, causando em poucos minutos um incendio geral, que produzio a destruição completa do edificio ${ }^{204}$.

Auxiliando Jose Carvalhido, estavam as cativas Joaquina, Ingracia, Henriqueta e o menor livre Maximo. Todos ficaram totalmente queimados. Jose Carvalhido e Joaquina poucas horas resistiram. Henriqueta e Ingracia morreram no dia seguinte. As vítimas, "em diversas senzalas, se extorcião".

As pessoas da família escaparam porque, no momento da explosão, estavam "se recreando no terreiro". Miguel Antonio Jorge estava ausente. Ele estava com a maioria dos seus cativos em outra propriedade, localizada no rio Etá. O juiz de Direito chegou às 4 horas da manhã em Caiacanga. Concluiu que o ocorrido "[...] não era filho de uma intenção perversa e sim resultado de uma fatalidade"205 e relatou ter encontrado "[...] o immenso edificio reduzido a cinzas e a desditoza familia espalhada pelo campo, em completo estado de desesperação, que se augmentara com os pungentes gemidos das victimas" 206 .

\footnotetext{
${ }^{204}$ Manuscritos e Ofícios Diversos. Xiririca. Ordem 4823, Lata 78. Arquivo do Estado de São Paulo. ${ }^{205}$ Manuscritos e Ofícios Diversos. Xiririca. Ordem 4823, Lata 78. Arquivo do Estado de São Paulo. ${ }^{206}$ Manuscritos e Ofícios Diversos. Xiririca. Ordem 4823, Lata 78. Arquivo do Estado de São Paulo.
} 


\section{Capítulo 2 - Rio Encantado}

O Rio Ribeira também serve de morada para muitos seres encantados. Atualmente, muitos moradores das comunidades remanescentes de quilombo de Eldorado e Iporanga afirmam que "tudo que tem na terra tem na água". Como exemplo, eles citam a presença no Rio Ribeira dos inofensivos bois d'água, vacas d'água, cachorros d'água e cavalos d'água. Também habita suas águas um ser perigoso - a mãe d'água. Porém, os entes mais lembrados são os negros d'água. De baixa-estatura, dentes muito brancos e pele muito preta, moram nas pedras existentes no fundo do rio. Essas histórias foram elaboradas e transmitidas pelas comunidades afrodescendentes que há centenas de anos habitam a região.

\subsection{Rio das Comunidades Negras}

No final do século XVIII, no Médio Ribeira, a decadência da mineração assinalou o decréscimo da população branca. A permanência dos negros derivou das alforrias e do abandono dos negros pelos senhores devido à dificuldade de manutenção da escravaria. Dessa forma, os negros - libertos, abandonados à própria sorte ou mesmo fugidos da escravidão - transformaram-se em pequenos produtores rurais autônomos. Eles ocuparam terras abandonadas e desbravaram áreas florestadas, num processo de interiorização orientado pelos rios. ${ }^{207}$

Na região de Xiririca, o povoamento começou a distanciar-se do Rio Ribeira, penetrando os seus afluentes, como o rio Xiririca, o Jaguari, o Batatal e o Pedro Cubas, chegando até os altos cursos dos rios secundários. De forma escassa e espaçada, os moradores da região erguiam um abrigo e abriam uma clareia para dar

\footnotetext{
${ }^{207} \mathrm{~A}$ formação das comunidades remanescentes de quilombo do Médio Ribeira foi analisada com mais detalhes no trabalho de PAES, Gabriela Segarra Martins. A "Recomendação das Almas" na Comunidade Remanescente de Quilombo de Pedro Cubas. 2007. Dissertação (Mestrado em História) - Faculdade de Filosofia, Ciências Humanas e Letras da Universidade de São Paulo, São Paulo, 2007.
} 
espaço a lavouras de subsistência. Desse modo, eles ocuparam morros e encostas. $^{208}$

No século XIX, muitos camponeses negros tiveram suas posses reconhecidas pelas autoridades locais e conseguiram inscrevê-las nos Registros de Terras de Xiririca e de Iporanga. No entanto, apesar do aumento do número de negros livres, a escravidão continuou existindo. A mão de obra cativa continuou a ser utilizada pelos proprietários mais abastados, principalmente por aqueles que se dedicavam ao cultivo do arroz - atividade econômica que, como visto, despontou na região no final do século XVIII e foi bastante expressiva ao longo do século XIX. Conforme a antropóloga Débora Stucchi:

\begin{abstract}
A coexistência de relações livres e escravistas no tempo e no espaço, demonstrada pela simultaneidade entre a ocupação das fazendas e a presença de pequenos produtores rurais negros no Vale do Ribeira, imprimiu uma especificidade que garantiu aos negros a constituição de uma vida social e econômica paralela à dominante, relativamente autônoma, embora de maneira nenhuma completamente isolada ${ }^{209}$.
\end{abstract}

Os camponeses negros plantavam principalmente arroz, mas também cultivavam feijão, café, milho, mandioca e cana-de-açúcar, entre outros gêneros. Eles vendiam os produtos para os donos de armazéns localizados nas margens dos rios. Os produtos eram escoados em canoas e barcaças para o porto de lguape.

Documentos eclesiais, analisados por Stucchi, apontam para a existência de relações entre escravizados e negros livres. De acordo com Stucchi:

\begin{abstract}
Uma considerável massa de dados eclesiais do período pré-abolição indica ainda a existência de relações de compadrio entre negros escravos de fazendas localizadas ao longo das duas margens do Rio Ribeira de Iguape e os pretos livres fixados em terras próximas aos seus afluentes. Tais relações, certamente, estariam ampliadas para além do registro da igreja, abrangendo regiões mais distantes, especialmente, rio acima ${ }^{210}$.
\end{abstract}

${ }^{208}$ PETRONE, Pasquale. A Baixada do Ribeira: estudo de geografia humana. 1960. Tese (Doutorado em Geografia) - Faculdade de Filosofia, Letras e Ciências Humanas da Universidade de São Paulo, São Paulo, 1960, p. 99-101.

209 STUCCHI, Débora; OLIVEIRA JUNIOR, Adolfo N.; CHAGAS, Miriam; BRASILEIRO, Sheila dos S.. Laudo antropológico das comunidades negras de Ivaporunduva, São Pedro, Pedro Cubas, Sapatu, Nhunguara, André Lopes, Maria Rosa e Pilões. In: ANDRADE, Tânia (ed.). Negros do Ribeira: reconhecimento étnico e conquista do território. São Paulo, ITESP, 2000, p. 73.

${ }^{210}$ Ibid., p. 160. 
As relações de compadrio revelam o entrelaçamento dos mundos dos escravizados e dos negros livres, sinalizando para a existência de arranjos familiares e sociais e para a constituição de um "campo negro", termo criado por Flávio Gomes para designar as teias de relações formadas por diversos personagens que vivenciaram os mundos da escravidão ${ }^{211}$.

O mapa a seguir retrata a região de Xiririca e arredores, entre os anos 1840 e 1880. Ele mostra as propriedades registradas pela Igreja que possuíam maior número de escravizados e os principais povoados habitados por negros livres.

\footnotetext{
${ }^{211}$ Flávio Gomes citou o exemplo de quilombolas em Iguaçu, no Rio de Janeiro, no século XIX. Eles negociavam com escravizados de fazendas vizinhas, com escravizados remadores, com taberneiros, entre outros atores sociais. Eles desenvolveram uma extensa rede de relações para fazer seu produto, lenha, chegar ao destino final, a Corte. Os contatos entre quilombolas, escravizados, lavradores, agregados e outros atores sociais constituíram uma rede complexa de relações sociais, o "campo negro". (GOMES, F. S. Quilombos do Rio de Janeiro no século XIX. In: REIS, J. R. e GOMES, F. S. (Orgs). Liberdade por um fio: História dos Quilombos no Brasil. São Paulo: Cia. das Letras, 1996, p. 277-278).
} 


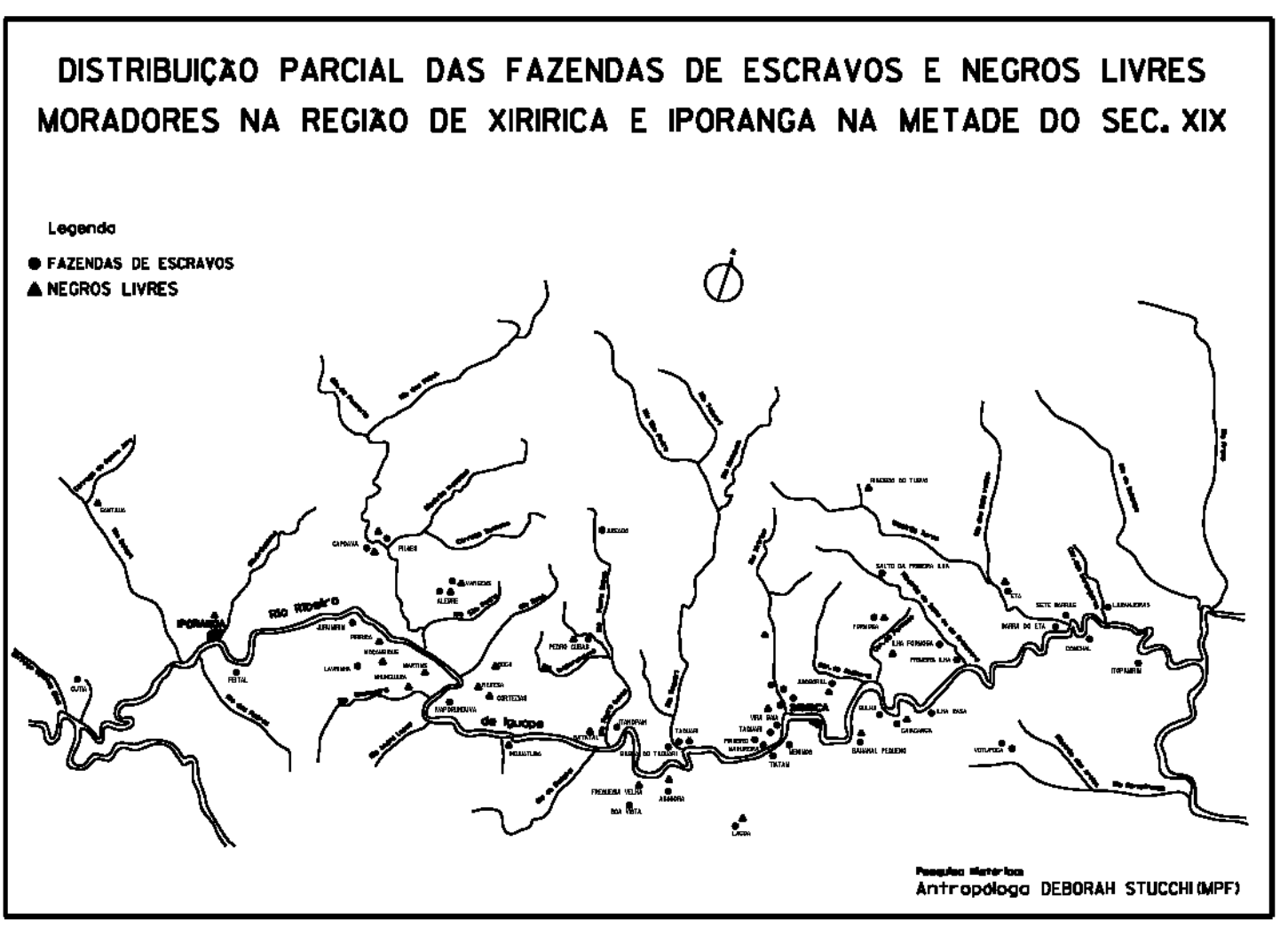


Os camponeses negros do Médio Ribeira ocuparam uma vasta área geográfica. O sistema agrícola adotado era a "coivara", no qual uma roça era aberta na mata densa. Primeiramente, derrubava-se a vegetação rasteira e a de pequeno porte e, depois, a de grande porte. O próximo passo era a queima da vegetação e, em seguida, o plantio. O sistema de coivara caracterizava-se pelo consorciamento de várias espécies, pela participação do grupo familiar e por ser voltado para a subsistência. O excedente podia ser comercializado. Outro aspecto importante era a grande mobilidade das populações que praticavam essa forma de cultivo, pois, depois de alguns anos, geralmente três, as terras tornavam-se menos férteis e eram abandonadas, iniciando a busca por novas áreas ${ }^{212}$.

Dessa maneira, a população espalhava-se na imensidão da floresta na busca contínua por novas terras. Essa população dispersa concentrava-se em algumas situações, como nos momentos de trabalho coletivo na roça e nas atividades lúdicoreligiosas. Essa população apresentava um modo de vida definido por Antonio Candido como "caipira", típico da população rural paulista tradicional ${ }^{213}$. As famílias não viviam isoladamente. Apesar de cada família viver em suas terras, estava atada a grupos de vizinhança, formando bairros rurais. As fronteiras desses bairros eram definidas pela participação dos moradores em trabalhos de ajuda mútua, ou seja, pertencia ao bairro quem convocava e quem era convocado para participar de atividades coletivas ${ }^{214}$. Ainda, os bairros rurais não estavam desgarrados uns dos outros. Relativamente autônomos, integravam-se em diferentes graus entre si e com a região ${ }^{215}$.

Um dos momentos mais importantes na vida "caipira" era quando os integrantes do bairro rural eram solicitados a participar do mutirão. Candido definiu mutirão da seguinte forma:

\footnotetext{
${ }^{212}$ PETRONE, 1960, p. 253.

${ }^{213}$ As regiões do Estado de São Paulo que foram tipicamente caipiras são as seguintes - todo o litoral paulista, o Vale do Paraíba, as serras da Mantiqueira, de Quebra Cangalha, do Mar e de Paranapiacaba, o Planalto Paulista, a zona Bragantina, a Depressão Periférica (ao longo do Rio Tietê, zona de Piracicaba, dos Campos Gerais, etc.), a zona do antigo "Caminho da Mata" e o Planalto de Franca. (PEREIRA QUEIROZ, Maria Isaura. Vale do Ribeira: pesquisas sociológicas. São Paulo: Faculdade de Filosofia, Letras e Ciências Humanas - USP, 1967, p. 70).

214 CANDIDO, Antonio. Os parceiros do Rio Bonito: estudo sobre o caipira paulista e as transformações dos seus meios de vida. 3 ed. São Paulo: Duas Cidades, 1964, p. 47.

${ }^{215}$ PEREIRA QUEIROZ, Maria Isaura. Bairros Rurais Paulistas. São Paulo: Duas Cidades, 1973, p. 13.
} 
Consiste essencialmente na reunião de vizinhos, convocados por um deles, a fim de ajudá-los a efetuar determinado trabalho: derrubada, roçada, plantio, limpa, colheita, malhação, construção de casa, fiação, etc. geralmente os vizinhos são convocados, e o beneficiário lhes oferece alimento e uma festa, que encerra o trabalho. Mas não há remuneração direta de espécie alguma, a não ser a obrigação moral em que fica o beneficiário de corresponder aos chamados eventuais dos que os auxiliaram. Este chamado não falta, porque é praticamente impossível a um lavrador, que só dispõe de mão-de-obra doméstica, dar conta do ano agrícola sem cooperação vicinal ${ }^{216}$.

Outro importante fator de coesão era a participação na vida religiosa do bairro. Desse modo, o bairro também podia ser definido como agrupamentos delimitados pela participação dos vizinhos nas atividades lúdico-religiosas locais. Ou seja, eram vizinhos os que participavam dos mesmos festejos religiosos ${ }^{217}$. Maria Isaura Pereira Queiroz sublinhou algumas das principais festas religiosas tradicionais - a Semana Santa, as festas dos santos padroeiros, a festa de Reis, da Santa Cruz, as festas juninas e a festa do Divino ${ }^{218}$.

Segundo Queiroz, baseando-se em Pasquale Petrone, o modo de vida tradicional (caipira) foi dominante no Estado de São Paulo até o século XIX, quando começou a sofrer os primeiros abalos representados pelo "Império do Café" ${ }^{219}$. Maria Helena Pereira Toledo Machado analisou algumas comunidades rurais formadas por libertos na província de São Paulo no século XIX. A pesquisadora destacou que o "[...] boom do café encobriu a realidade tanto das regiões menos integradas ao circuito exportador quanto das áreas marginais às grandes fazendas"220.

As terras tinham reduzido valor comercial nas áreas menos integradas à agricultura comercial, o que tornava o cenário propício para o estabelecimento dos libertos em pequenas glebas. Porém, havia as dificuldades enfrentadas pelos negros para legalizar as terras ocupadas, conforme sublinhado por Machado. Entre outros exemplos, há o caso da comunidade negra de Guareí, localizada em Tatuí.

\footnotetext{
${ }^{216}$ CANDIDO, op. cit., p. 48.

${ }^{217}$ CANDIDO, op. cit., p. 51.

${ }^{218}$ PEREIRA QUEIROZ, 1973, p. 57.

${ }^{219}$ Ibid., p. 8.

${ }^{220}$ MACHADO, Maria Helena Pereira Toledo. Vivendo na mais perfeita desordem: os libertos e o modo de vida camponês na província de São Paulo no século XIX. Estudos Afro-Asiáticos, n. 25, p. 25-42, dezembro de 1993, p. 29.
} 
Integrada ao caminho das tropas entre Curitiba e Sorocaba, a região, no começo do século XIX, dedicava-se apenas à agricultura de gêneros de subsistência e à criação de gado. Depois, a região foi introduzida nos circuitos da economia exportadora paulista, primeiramente, com os ensaios de uma produção açucareira e, a partir da segunda metado do século, com a expansão do café 221 .

Quanto à origem da comunidade do Guareí, constava no testamento de Américo Aires do Amaral, falecido em 1843, a doação de uma faixa de terra marginal a sua fazenda a dois escravizados. No entanto, os descendentes de Américo Aires do Amaral se declararam os legítimos detentores da área. Eles entraram na Justiça e exigiram a retirada dos libertos, sem direito a qualquer indenização. Em 1880, a área ainda era ocupada pelos libertos e seus descendentes. Nesse ano, contava com mais de 80 pessoas que ocupavam parte indefinida dos 1.250 alqueires da propriedade original. Porém, nem a legitimidade da doação, nem a antiguidade da posse, tampouco o desenvolvimento da comunidade impediram a tramitação favorável aos descendentes de Américo Aires do Amaral. Foi dada ordem de ação de despejo contra a comunidade. Iniciada em 1881, a sentença final foi dada, apenas, em 1886. A comunidade resistiu, armou-se, angariou a simpatia da população e a proteção de poderosos locais, os quais procuraram impedir o envio de tropas de São Paulo. No entanto, em 1889, ocorreram mudanças na correlação das forças políticas locais e a ação do despejo foi efetivada. Foi enviada força pública de São Paulo para a reintegração de posse. Os negros resistiram à ação de despejo e a força pública agiu com violência - matou duas pessoas, prendeu grande número de moradores e queimou casas, benfeitorias e criações. De acordo com Machado:

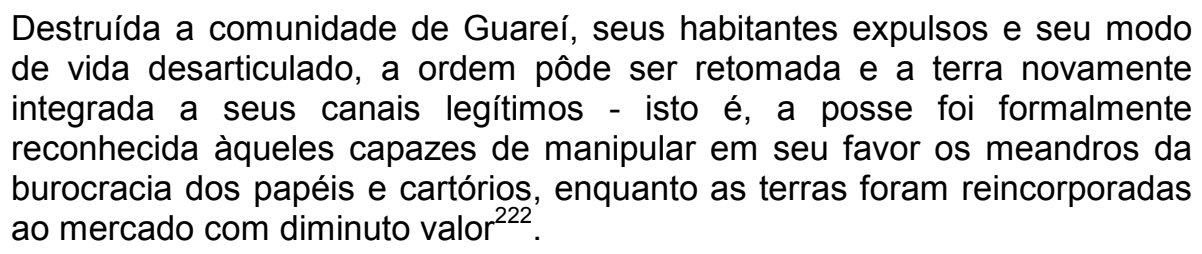

Destruída a comunidade de Guareí, seus habitantes expulsos e seu modo de vida desarticulado, a ordem pôde ser retomada e a terra novamente integrada a seus canais legítimos - isto é, a posse foi formalmente reconhecida àqueles capazes de manipular em seu favor os meandros da ao mercado com diminuto valor ${ }^{222}$.

Machado destacou que, se a presença de comunidades de libertos em áreas de pouca expressividade econômica ou em terras marginais às fazendas já

\footnotetext{
${ }^{221} \mathrm{MACHADO}, 1993$, p. 30.

${ }^{222}$ Ibid., p. 31.
} 
provocava tensão, a situação era ainda mais grave quando os libertos tentavam se assenhorar de fazendas produtivas. Segundo a pesquisadora:

[...] as tentativas de permanência de grupos de libertos nessas áreas encontraram, desde logo, flagrantes hostilidades. Articulações rápidas e certeiras de toda uma comunidade de interesses afrontada não tardam em varrer exemplarmente essa possibilidade nos canais legítimos de acesso à liberdade e propriedade de terra" ${ }^{\text {"23. }}$.

Diferentemente de outras regiões de São Paulo, o Vale do Ribeira mantevese à margem do boom do café e, no século $\mathrm{XX}$, não passou por um processo de industrialização significativo. A região permaneceu apresentando um modo de vida tradicional. Ao longo do século $X X$, o Vale do Ribeira foi descrito como uma região não integrada ao restante do Estado de São Paulo. Ele foi apontado como uma região de natureza exuberante e riquezas minerais, mas um exemplo de insucesso perante as demais regiões do Estado. Pesquisadores e órgãos do governo frisavam a diferença entre a sociedade urbano-industrial encontrada em várias regiões de São Paulo, entendidas como modernas, eficientes, racionais, prósperas e dinâmicas; e o Vale do Ribeira, visto como agrário, pouco povoado, isolado, cujo trabalho na lavoura era realizado a partir de métodos rudimentares, com pequena produção e voltado para a subsistência ${ }^{224}$.

A partir dos anos 50, aumentou o interesse do Estado de São Paulo pelo Vale do Ribeira. Várias pesquisas foram encomendadas para detectar possíveis saídas para o "desenvolvimento" da região. Os estudos defendiam a vocação do Vale do Ribeira para a mineração, o turismo e a agroindústria ${ }^{225}$. Nessa época, durante os anos do governo Juscelino Kubitschek, o Programa de Metas priorizou a geração de energia e a construção de estradas. Em 1958, a BR-116 foi construída, facilitando a comunicação entre Registro e São Paulo ${ }^{226}$.

Se até meados de 1950 os lavradores do Médio Ribeira viviam sob um modo

\footnotetext{
${ }^{223}$ MACHADO, 1993, p. 32.

${ }^{224}$ CARRIL, 1995, p. 86.

${ }^{225}$ MARTINEZ, Maria Cecília. Ação governamental e resistência camponesa no Vale do Ribeira. 1995. Dissertação (Mestrado em História) - Faculdade de Filosofia, Letras e Ciências Humanas da Universidade de São Paulo, São Paulo, p. 18.

${ }^{226}$ PEREIRA QUEIROZ, 1967, p. 27.
} 
tradicional, mudanças significativas começaram a surgir a partir desse período. $\mathrm{Na}$ década de 40, uma fábrica de palmito foi instalada nas proximidades do rio Pilões ${ }^{227}$. A partir da década de 50, a demanda pelo palmito-juçara aumentou e a ampla cobertura florestal possibilitou aos moradores da região atendê-la. Muitos lavradores abandonaram o trabalho na roça e passaram a se dedicar, apenas, ao corte de palmito. A extração do palmito-juçara representou o primeiro abalo no modo de vida tradicional e contribuiu para o enfraquecimento da autonomia dos lavradores e dos padrões tradicionais de ajuda mútua ${ }^{228}$. Segundo Sanchez:

Dos anos 50 aos anos 80 do século $\mathrm{XX}$, muitos dos moradores desses bairros abandonaram as roças como principal atividade produtiva e se embrenharam no "sertão" e nas matas em busca de palmito. A economia da região passou a girar em torno desse extrativismo que se tornou a grande fonte de renda dessa população ${ }^{229}$.

A partir da década de 50, o movimento ambientalista fortaleceu-se. Consequentemente, em 1965, o corte de palmito-juçara passou a ser considerado delito. Contudo, os moradores do Médio Ribeira não abandonaram a atividade extrativista, mesmo tendo ela se tornado ilegal. Ademais, várias indústrias de conserva de palmito foram instaladas no Vale do Ribeira. Os moradores do Médio Ribeira, ao praticarem uma atividade ilegal, além de sofrerem possíveis penalidades, ficavam dependentes do "atravessador" - pessoa responsável pela comercialização clandestina do produto $^{230}$. Tanto a demanda quanto a quantidade de palmito era muito grande e, assim, esse recurso florestal foi explorado à exaustão. Com o tempo, o palmito foi tornando-se cada vez mais escasso, e muitas fábricas foram fechadas.

Parques estaduais e áreas de preservação ambiental foram implantados no Vale do Ribeira devido ao fortalecimento do movimento ambientalista, haja vista que

${ }^{227}$ FIGUEIREDO, Luiz Afonso Vaz. O meio ambiente prejudicou a gente. 2000. (Dissertação em Educação) - Faculdade de Educação da Universidade de Campinas, 2000, 1994, p. 110.

${ }^{228}$ QUEIROZ, Renato da Silva. Negros do Vale do Ribeira: um estudo de antropologia econômica. São Paulo: Edusp, 2006, p. 53.

${ }^{229}$ SANCHEZ, Fábio Jose Bechara. Identidade e conflito: a construção política dos "remanescentes de quilombo" do Vale do Ribeira. 2004. Dissertação (Mestrado em) - Faculdade de Filosofia, Letras e Ciências Humanas da Universidade de São Paulo, 2004, p. 86.

${ }^{230}$ CARRIL, Lourdes de Fátima Bezerra. Terra de Negros no Vale do Ribeira: territorialidade e resistência. 2005. Dissertação (Mestrado em História) - Faculdade de Filosofia, Letras e Ciências Humanas da Universidade de São Paulo, 1995, p. 114. 
os maiores remanescentes de Mata Atlântica do Estado de São Paulo concentravam-se (e ainda concentram-se) no Vale do Ribeira ${ }^{231}$. A região também possuía muitas terras devolutas (terras não tituladas, portanto, pertencentes ao Estado), o que favoreceu a implantação de áreas de preservação ambiental pelo governo. Contudo, apesar das terras serem devolutas, não eram desabitadas. De acordo com Stucchi: "[...] a política de criação de parques estaduais tem sido realizada sob o pressuposto de que terras discriminadas como devolutas estão livres da presença humana, pouco importando a ocupação centenária e imemorial das comunidades negras da região" ${ }^{232}$. Os parques e áreas de preservação impactaram o modo de vida tradicional dessas comunidades.

Em 1958, foi implantado o Parque Estadual do Alto Ribeira (PETAR), com 35.884 hectares. Em 1969, foi criado o Parque Estadual de Jacupiranga, que possui 150.000 hectares. Ele é o segundo maior parque do Estado de São Paulo e se estende sobre os municípios de Jacupiranga, Iporanga, Eldorado, Cajati, Barra do Turvo e Cananéia. Após a sua criação, as comunidades negras da região, especialmente Nhunguara e André Lopes, foram empurradas para as bordas do parque $^{233}$.

Em 1995, com 46.086 hectares, o Parque Estadual de Intervales foi instituído através de um decreto estadual que anexava duas glebas de terras devolutas à Fazenda Intervales, antiga propriedade do Estado de São Paulo. Porém, apesar de devolutas, as duas glebas eram ocupadas pelas comunidades negras de São Pedro, Maria Rosa, Pilões, Pedro Cubas e Ivaporunduva. Nesse mesmo ano, as comunidades negras de Ivaporunduva, Pedro Cubas e São Pedro informaram a Procuradoria da República sobre a incorporação de suas terras ao parque ${ }^{234}$.

Em 1984, estendendo-se sobre onze municípios do Vale do Ribeira, foi criada a Área de Proteção Ambiental (APA) da Serra do Mar. Diferentemente das áreas de parque, nas APAs, o uso da biodiversidade não é totalmente proibido. Dessa forma,

${ }^{231}$ Segundo Martinez, durante o governo militar, o Vale do Ribeira foi visto como "foco residual de insegurança" e "ninho de guerrilhas" devido à baixa densidade populacional e a existência de amplos espaços de mata virgem. A Vanguarda Popular Revolucionária (VPR), sob o comando de Carlos Lamarca, instalou ali um campo de treinamento militar, o qual foi desmantelado pelo Exército. (MARTINEZ, 1995, p. 78).

${ }_{232}^{2}$ STUCCHI et al., 2000, p. 113.

${ }^{233}$ Ibid., p. 115.

${ }^{234}$ Ibid., p. 115. 
uma APA é uma unidade de conservação que permite o uso de seus recursos naturais, desde que seja de forma racional e sustentável. Conforme Stucchi, "A criação da APA da Serra do Mar promoveu a intensificação das atividades fiscalizadoras na região, de modo que, a partir da década de 1980, viu-se dificultada ou impedida, na maioria das situações, a atividade agrícola"235.

A autorização do órgão estadual competente passou a ser necessária para a abertura de novos roçados. Ao restringir o uso dos recursos naturais, a criação de parques e da APA da Serra do Mar contribuiu para a redução da autonomia do pequeno lavrador. Assim, representou mais um fator de mudança ao modo de vida tradicional dos moradores do Médio Ribeira.

Outra mudança significativa foi a construção, em 1969, da estrada de rodagem que liga as sedes dos municípios de Eldorado e Iporanga. Antes dessa data, o trajeto era realizado pelo Rio Ribeira. Conforme depoimento coletado por Renato da Silva Queiroz, em Ivaporunduva, no final dos anos 70: "Antigamente era custoso, a gente não tinha estrada, o recurso era a canoa mesmo. Morria muita gente n'água, dava muito prejuízo. Depois que abriram a estrada, acabou o morrimento de gente" 236 .

A estrada de rodagem possibilitou a intensificação do contato dos moradores do Médio Ribeira com a sociedade envolvente. Além disso, interesses econômicos foram despertados pela disponibilidade de imensas extensões de terra. Após a construção da estrada, surgiu o que os moradores da região chamam de "terceiros" pessoas vindas de fora e que adquiriam terras no local, seja através da compra por preços muito baixos, seja através do uso da violência. Outro procedimento comum era a compra de uma pequena área e sua expansão através do uso da violência e da intimidação. Desse modo, "[...] mediante a compra de 'direitos' de posse a preços irrisórios, da intimidação e do emprego sistemático da grilagem, era possível tornarse dono, rápida e quase gratuitamente, de extensas propriedades"237.

Renato da Silva Queiroz apontou que, entre 1960 e 1970, em Eldorado, cresceu a área ocupada por "grileiros". O pesquisador também notou que, a partir

\footnotetext{
${ }^{235}$ STUCCHI et. al., 2000, p. 99.

${ }^{236}$ Entrevista realizada por Queiroz. (QUEIROZ, 2006, p. 35).

${ }^{237}$ QUEIROZ, op. cit., p. 59-61.
} 
dos anos 50 e, principalmente, depois dos anos 70, aumentou o número de propriedades privadas na região. As áreas tornavam-se particulares através de maneiras variadas, como os meios legais, as falsificações documentais, a expulsão e a grilagem. Outro fato relevante foi o avanço das áreas de pastagens, as quais cresceram mais de três vezes entre os anos de 1950 e 1970, o que refletia a aceleração do desmatamento ${ }^{238}$.

Portanto, existiu uma associação entre "terceiros", a legalização de terras e o desmatamento. Desse modo, a presença desses "terceiros", com novos padrões de ocupação do espaço, contribuiu para a intensificação dos conflitos entre eles e os moradores tradicionais do Médio Ribeira, além de abalar, ainda mais, o modo de vida tradicional das comunidades negras da região.

Com a construção da estrada de rodagem Eldorado-lporanga e a intensificação do contato entre moradores do Médio Ribeira e a sociedade envolvente, novas ideias passaram a circular com mais facilidade. Ademais, num momento posterior, com a chegada da eletricidade e, consequentemente, do rádio e da televisão, essas ideias circularam ainda mais velozmente, interferindo nos hábitos e nos valores tradicionais das comunidades negras da região.

Uma questão importante, que ameaça não apenas as comunidades negras, mas o próprio território, relaciona-se com os projetos de construção de barragens ao longo do Rio Ribeira. As discussões sobre as barragens remontam à década de 30 do século $X X^{239}$. Em 1953, cinco barragens ao longo do Rio Ribeira foram planejadas. No entanto, os projetos foram adiados devido ao pequeno potencial hidrelétrico do Rio Ribeira de Iguape. Porém, no final dos anos 1970, o interesse pela construção de barragens ressurgiu. A Companhia Energética de São Paulo (CESP) pediu ao Ministério das Minas e Energia autorização para pesquisar a viabilidade técnico-econômica da bacia hidrográfica do Rio Ribeira de Iguape. A CESP projetou três hidrelétricas ao longo do Ribeira, no entanto, não providenciou as exigências necessárias para a sua construção e, atualmente, não tem se manifestado sobre o assunto ${ }^{240}$.

\footnotetext{
${ }^{238}$ QUEIROZ, 2006, p. 55-60.

${ }^{239}$ PEREIRA QUEIROZ, 1967, p. 50.

${ }^{240}$ CARRIL, 1995, p. $125-129$.
} 
A CBA (Companhia Brasileira de Alumínio), do grupo Votorantim, manifestou interesse na construção de uma usina hidrelétrica no Alto Ribeira, no município de Ribeira, entre os estados de São Paulo e Paraná. O Rio Ribeira nasce no Paraná e deságua em São Paulo. Ele é o último rio de médio porte do Estado de São Paulo não barrado. A construção de barragens implicaria na inundação de extensas áreas de Mata Atlântica, na destruição de significativo patrimônio espeleológico e na retirada de pequenos lavradores da região. Ambientalistas alertam que o lago formado com a barragem do Ribeira inundaria áreas de mineração antigas e atuais, acarretando a concentração de metais pesados no seu fundo e a contaminação da vida aquática do rio ${ }^{241}$.

Os Conselhos Estaduais do Meio Ambiente do Paraná e de São Paulo aprovaram uma licença prévia para a construção da hidrelétrica projetada pela CBA, a Usina Hidrelétrica de Tijuco Alto. No entanto, em 1994, a licença foi suspensa porque, como o rio atravessa dois estados, cabia ao governo federal e, portanto, ao Instituto Brasileiro do Meio Ambiente e das Riquezas Naturais Renováveis (IBAMA), emitir a licença. Em 1997, a CBA solicitou licença ao IBAMA para a construção da Hidrelétrica de Tijuco Alto, mas o pedido foi indeferido em setembro de $2003^{242}$. Neste mesmo ano, a CBA apresentou recurso administrativo contra a decisão. Em 2007, foram realizadas audiências públicas em municípios do Vale do Ribeira, onde ocorreram manifestações contrárias à obra ${ }^{243}$. $\mathrm{Na}$ fase atual do processo de licenciamento, incumbe à Fundação Cultural Palmares (FCP) - entidade pública vinculada ao Ministério da Cultura, cuja missão é promover a preservação dos valores culturais, sociais e econômicos decorrentes da influência negra na formação da sociedade brasileira - manifestar sua posição sobre a obra, antes que o IBAMA se pronuncie sobre a concessão da licença prévia. Em 2013, a Fundação Cultural Palmares manifestou-se favoravelmente à emissão da licença prévia, no entanto, em reunião ocorrida no dia 23 de maio de 2013, as comunidades quilombolas da região questionaram a decisão e fizeram com que a Fundação Cultural sustasse os efeitos de seu pronunciamento e agendasse visita às comunidades quilombolas da região

\footnotetext{
${ }^{241}$ CARRIL, 1995., p. 131.

${ }^{242}$ SANCHEZ, 2004., p. 101.

243 O Projeto Tijuco Alto e seu histórico. Instituto Socioambiental. Disponível em <http://www.socioambiental.org/inst/camp/Ribeira/tijuco>. Acesso em 29 de abril de 2014.
} 
para ouvi-las previamente sobre a construção da hidrelétrica ${ }^{244}$.

\subsubsection{A Identidade Quilombola}

Resultado da pressão política do movimento negro, a questão quilombola foi debatida na Assembleia Nacional Constituinte e, no dia 22 de junho de 1988, o artigo 68 do Ato das Disposições Transitórias foi aprovado com a seguinte redação: "Aos Remanescentes das Comunidades dos Quilombos que estejam ocupando suas terras é reconhecida a propriedade definitiva, devendo o Estado emitir-lhes os respectivos títulos".

A partir de então, o termo "comunidade remanescente de quilombo" tornou-se uma categoria jurídica e ganhou visibilidade no cenário nacional. O termo quilombo ganhou novas definições após a Constituição de 1988. Além das comunidades originadas de processos de fuga, também passaram a ser considerados os processos de abandono de terras, de herança, de doação, de compra, entre outros.

Outros critérios passaram a ser levados em conta, como a questão da autoatribuição e da alteridade em relação à sociedade envolvente. O decreto federal n. 4.887 de 20 de novembro de 2003 estabeleceu a seguinte definição:

Consideram-se remanescentes das comunidades dos quilombolos, para fins deste Decreto, os grupos étnicos-raciais, segundo critério de autoatribuição, com trajetória histórica própria, dotados de relações territoriais específicas, com presunção de ancestralidade negra relacionada com resistência à opressão histórica sofrida.

As comunidades negras do Médio Ribeira e do Alto Ribeira mobilizaram-se conjuntamente contra as adversidades e se autoidentificaram como comunidades

\footnotetext{
${ }^{244}$ Implantação da Usina Hidrelétrica de Tijuco Alto. Centro de Apoio Operacional das Promotorias de Direitos Constitucionais. Disponível em $<$ http://www.direito.caop.mp.pr.gov.br/modules/noticias/article.php?storyid=247>. Acesso em $29 \mathrm{de}$ abril de 2014.
} 
remanescentes de quilombo, lutando assim para garantir a propriedade definitiva de suas terras, conforme Ihes assegura a Constituição Federal. Os bairros negros do Médio Ribeira originaram as comunidades remanescentes de quilombo de Pedro Cubas, Pedro Cubas de Cima, Sapatu, Nhunguara, São Pedro, Galvão, Ivaporunduva, André Lopes, Pilões, Maria Rosa, Praia Grande e Bombas. No Alto Ribeira, localizam-se as comunidades remanescentes de quilombo de Porto Velho e Cangume.

Fábio José Bechara Sanchez destacou alguns problemas diretamente relacionados com a identidade quilombola das comunidades da região: a situação fundiária conflituosa, as restrições impostas pela legislação ambiental e a ameaça da construção de barragens ao longo do Rio Ribeira ${ }^{245}$.

Pode-se, assim, afirmar que a identidade quilombola é uma identidade política. É a forma como os negros da região escolheram se apresentar aos agentes externos e, dessa forma, reivindicar seus direitos. Nesses embates e diálogos com os vários sujeitos que apareceram na região nas últimas décadas, destacamos a presença de segmentos progressistas da Igreja Católica. Na década de 80, as religiosas Ângela Biagioni e Maria Sueli Berlanga foram chamadas pelo Bispo da Diocese de Registro para atuar na região de Eldorado. Integrantes da Congregação Jesus Bom Pastor, as religiosas se preocuparam com o problema da exclusão social das comunidades rurais da região. A Igreja Católica fomentou o Movimento dos Ameaçados por Barragens (MOAB). A identidade quilombola foi, assim, sendo elaborada pelos moradores dos bairros rurais negros a partir do diálogo com outros atores sociais, num contexto de luta e enfrentamento.

Nesse processo, em 1994, representantes da Comunidade Remanescente de Ivaporunduva pleitearam o reconhecimento e a titulação de suas terras junto à Justiça Federal de São Paulo. No ano seguinte, solicitaram apoio institucional da Procuradoria da República e noticiaram a existência de outras comunidades negras na região. No mesmo ano, o Ministério Público Federal visitou a comunidade de Ivaporunduva. A partir desse momento, intensificaram-se os contatos entre os diferentes órgãos do Estado e as comunidades negras.

${ }^{245}$ SANCHEZ, 2004, p. 55. 
Nos anos seguintes, o Governo do Estado de São Paulo editou decretos com o objetivo de aplicar o artigo 68 da Constituição Federal em solo paulista. Entre as diferentes entidades governamentais que travaram diálogo com as comunidades negras, ressaltamos a Fundação Instituto de Terras do Estado de São Paulo (Fundação ITESP). Esse órgão estadual é responsável pela identificação e reconhecimento das comunidades remanescentes de quilombo e pela demarcação e titulação dos territórios, além de fornecer assistência técnica e apoio para atividades socioeconômicas. Até o momento, seis comunidades remanescentes de quilombo do Vale do Ribeira foram tituladas: Ivaporunduva, São Pedro, Pedro Cubas, Maria Rosa, Pilões e Galvão.

\subsection{Negros d'água nas Comunidades Remanescentes de Quilombo de Eldorado e Iporanga}

Ainda hoje, moradores mais velhos das comunidades de quilombo de Eldorado e Iporanga afirmam já terem visto negros d'água no Rio Ribeira ${ }^{246}$. Embora declarem que eles andem sumidos, sustentam que negros d'água eram muito presentes até alguns anos atrás. Os informantes atuais concordam quanto à cor da pele ("bem pretinho") e dos dentes ("bem branquinho"). Também assentem quanto a sua baixa estatura. Divergem quanto ao cabelo - em alguns relatos, o cabelo é definido como "muito seco" e, em outros, os negros são descritos como possuidores de uma "cabeça pelada". Também não há consenso quanto aos pés. Para a maioria dos informantes, seus pés eram normais, no entanto, alguns relataram que eles possuíam pés-de-pato, aspecto atestado por Rosana Mirales. A partir de entrevistas realizadas na região, a pesquisadora afirmou que, na época da escravidão, os negros d'água eram colocados "[...] em tanques, para que se adaptassem ao mundo da terra. Ali tinham as mãos e os pés cortados com navalhas, uma vez que eram

\footnotetext{
${ }^{246}$ As informações referentes aos negros d'água foram obtidas com os moradores das comunidades remanescentes de quilombo de Eldorado e Iporanga entre os anos de 2001 e 2008.
} 
como os de patos"247.

Segundo os relatos, os negros d'água viravam as canoas que trafegavam pelo rio, e isso exigia que os canoeiros ficassem atentos. Assim que avistavam as mãos dos negros d'água tocando em suas canoas, batiam com um remo, ou, com um facão, cortavam os dedos dos negros d'água. Alguns achavam que, com exceção de virar as canoas, os negros d'água não ofereciam perigo. Muitos sublinharam o seu espírito brincalhão e relataram que eles faziam gracejos para as pessoas da terra. No entanto, outros acreditam que os negros d'água gostavam de fazer maldade. Alguns dizem que eles encantavam as mulheres e as levavam para viver com eles no fundo dos rios. Outros acreditavam que eles matavam os homens e comiam as crianças. Os relatos convergem para poços fundos e revessas como local de moradia dos negros d'água. Muitos destacaram que, na realidade, eles moravam nas grutas existentes no fundo dos rios, onde era seco.

Embora morassem no fundo do rio, muitas vezes aproximavam-se das suas margens. Eram vistos sentados ou próximos das pedras existentes no rio. Esses momentos eram perigosos, pois tanto os negros d'água podiam capturar as pessoas da terra e levar para o fundo do rio, como podiam ser capturados pelas pessoas da terra. A captura de negros d'água era realizada com redes, tarrafas, laços e cordas. Muitos deles foram sequestrados e passaram a viver na terra. Tiveram que ser amansados e, para isso, deram-Ihes comida com sal, desconhecida por eles. Esses negros acabaram se adaptando à vida na terra, aprenderam a língua, casaram-se com pessoas da terra e tiveram filhos. Desse modo, muitos dos atuais habitantes das comunidades quilombolas de Eldorado e Iporanga afirmaram descender de "nação de negros d'água".

Rosana Mirales detalhou como o corpo era adaptado para sobreviver num mundo diferente do original. Assim, quando o negro d'água transportava uma pessoa da terra , "[...] para que a pessoa que está sendo levada para o outro mundo não morra, o negro da água a coloca nas costas, e, ao se locomover no interior da água, forma em sua coluna vertebral um canal de ar, de maneira que, quem está

\footnotetext{
247 MIRALES, Rosana. A identidade quilombola das comunidades Pedro Cubas e Ivaporunduva. 1998. (Dissertação em Ciências Sociais) - Programa de Pós-Graduação em Ciências Socias da Pontifícia Universidade Católica, São Paulo, 1998, p. 73.
} 
sendo carregado, não se afoga"248. O negro d'água não se afogava porque possuía uma pedra no estômago, a qual permitia que sobrevivesse na água. No entanto, a mesma pedra transformava-se em veneno na terra e, para expeli-la, o negro d'água deveria comer sal. Conforme Mirales:

\begin{abstract}
Para que as pessoas da água se adaptem ao mundo da terra, é necessário que, após a sua captura pelos da terra, vomitem a pedra que possuem no estômago. Para que isto ocorra, o sal é essencial; por isso, quando é apreendido um negro d'água, as pessoas da terra lhe oferecem comida salgada. Quando ele resolve resistir, desejando voltar para o seu mundo, só aceita leite e doce, não perdendo o seu encanto; e foge pelo rio, quando consegue. A fuga deve ocorrer rapidamente, uma vez que ele não consegue sobreviver muito tempo fora da água, já que a pedra do estômago, na terra, transforma-se em veneno, provocando a morte da pessoa ${ }^{249}$.
\end{abstract}

Há muitos relatos de negros d'água que foram capturados. Em Ivaporunduva, contam um fato ocorrido há muitos anos durante a festa de Santa Cruz, comemorada no dia 3 de maio e com duração de cerca de três dias. Nesses dias, Ivaporunduva recebia muitas pessoas, grande parte de lugares distantes. Além de festar, comer e beber, as pessoas também participavam das atividades religiosas realizadas na igreja. Um vigário acompanhava as atividades. As pessoas faziam novena, confessavam e comungavam. Num dos dias da festa, alguns homens foram pescar. Lançaram a rede e, ao puxá-la, além dos peixes, também havia um menino. Era um negro d'água. Arisco, o negro d'água foi amarrado e levado até o local da festa. Ele foi vestido e, em seguida, batizado pelo vigário. Passou a ser chamado Inácio Marinho. Deram-Ihe comida com sal e, assim, aos poucos, foi amansado. Tempos depois, casou-se e teve filhos. Muitos dos seus descendentes vivem, atualmente, na região e carregam o seu sobrenome, Marinho.

Outro negro d'água, cujo nome e sobrenome ainda é muito lembrado, chamava-se Gregório Marinho. Há muitos anos, ao passear pela superfície do rio, onde hoje se localiza a Comunidade Remanescente de Quilombo de Pedro Cubas, o negro d'água encantou-se com uma escravizada que vivia na localidade. Também encantada pelo negro d'água, a escravizada incentivava as vindas do seu admirador. Planejando capturá-lo, ela passou a preparar comida com sal, sem que o negro d'água desconfiasse. Aos poucos, ele foi amansando. Um dia, a negra pediu auxílio

\footnotetext{
${ }^{248}$ MIRALES, op. cit., p. 74 .

${ }^{249}$ MIRALES, op. cit., p. 72.
} 
para outras pessoas e, assim, o negro d'água foi capturado. Foi construído um tanque na terra para que ele conseguisse sobreviver. Como o negro d'água não tinha nome, passou a ser chamado de Gregório Marinho. A cativa e o negro d'água constituíram família. Os seus descendentes são os atuais moradores da comunidade de Pedro Cubas.

Documentos históricos mostram que, realmente, existiu um Inácio Marinho ${ }^{250}$ em Ivaporunduva e um Gregório Marinho ${ }^{251}$ em Pedro Cubas em meados do século $\mathrm{XIX}$. Existiram e possuíram terras, as quais foram registradas pelo pároco de Xiririca $^{252}$. Outros Marinhos estão presentes no Registro de Terras de Xiririca. Também registraram suas terras - em Ivaporunduva, Francisco Marinho ${ }^{253}$ e João Marinho $^{254}$ e, em Pedro Cubas, Vicente Marinho ${ }^{255}$.

A presença dos Marinhos históricos, captados pela documentação, e dos míticos, lembrados pela população local, apontam para a importância e para o enraizamento da crença dos negros d'água na região.

\footnotetext{
${ }^{250}$ Registro de Terras de Xiririca, sob assento n. 412. Arquivo do Estado de São Paulo.

${ }^{251}$ Registro de Terras de Xiririca, sob assento n. 465. Arquivo do Estado de São Paulo.

252 Terras Registradas entre 01 de dezembro de 1854 e 28 de maio de 1856. Arquivo do Estado de São Paulo.

${ }^{253}$ Registro de Terras de Xiririca, sob assento n. 269. Arquivo do Estado de São Paulo.

${ }^{254}$ Registro de Terras de Xiririca, sob assento n. 481 e n. 487. Arquivo do Estado de São Paulo.

${ }^{255}$ Registro de Terras de Xiririca, sob assento n. 488. Arquivo do Estado de São Paulo.
} 


\subsection{Negros d'água no Brasil}

A presença de negros d'água no Brasil foi destacada por alguns pesquisadores. O mito foi observado na região central do país: nos rios São Francisco, Paraná, Tocantins e Cuiabá ${ }^{256}$.

A descrição do negro d'água coletada por José A. Teixeira é muito semelhante à versão existente no Vale do Ribeira: "Habita as margens dos rios que correm pelo vão do Paraná. É todo preto. Cabeça pelada. Mãos e Pés de pato. Aparece entre pedras, à tardinha ou em noites de luar, a canoeiros e pescadores do Tocantins e seus afluentes. E procura virar a canoa"257.

Também chamado de caboclo d'água, foi definido por Câmara Cascudo da seguinte forma:

[...] criatura fantástica que vive no rio São Francisco, tendo o domínio sobre as águas e os peixes. Favorece tudo aos amigos, compadres do caboclo d'água, e persegue ferozmente aos pescadores e barranqueiros, com que antipatiza, virando canoas, erguendo ondas, derrubando as barreiras, afugentando pescarias ${ }^{258}$.

O caboclo d'água é um dos mitos aquáticos mais conhecidos do vale do rio São Francisco ${ }^{259}$. A ele está associada a presença das carrancas do rio São Francisco, figuras assustadoras esculpidas nas proas das embarcações. Segundo Joaquim Ribeiro: "Dizem os pescadores que essas carrancas conjuram os malefícios do caboclo d'água, entidade mítica do rio"260. D. Martins de Oliveira afirmou que "[...] as cabeças de barca velam em defesa da embarcação e de seus tripulantes, contra as perseguições do caboclo d'água que, não raro, vira as embarcações e afoga os remeiros e pescadores rebeldes ou infiéis, no seio das águas" ${ }^{261}$.

\footnotetext{
${ }^{256}$ CASCUDO, Luís da Câmara. Dicionário do Folclore Brasileiro. $10^{a}$ ed. Rio de Janeiro: Ediouro Publicações Ltda, 1998, p. 209.

${ }^{257}$ TEIXEIRA, José A., 1941, p. 391 apud CASCUDO, 1998, p. 210.

${ }^{258}$ CASCUDO, op. cit., p. 209.

259 PARDAL, Paulo. Carrancas do São Francisco. Rio de Janeiro: Serviço de Documentação da Marinha, 1974, p. 54.

${ }^{260}$ RIBEIRO, Joaquim, Folclore de Januária, p. 49 apud PARDAL, 1974, p. 70.

${ }^{261}$ OLIVEIRA, 1957 apud PARDAL, 1974., p. 69.
} 
Para Clarival Valladares, as carrancas eram usadas para defender os barqueiros não só contra o caboclo d'água, mas também contra a cachorrinha-daágua e o minhocão ${ }^{262}$. Alguns pesquisadores também foram mais gerais quando abordaram as motivações para a existência das carrancas. O próprio Clarival Valladares afirmou que as carrancas serviam de "[...] proteção dos navegantes e da barca, contra as maldições do rio"263.

\section{Conforme C. Vasconcellos Maia:}

Ouvi dizer, por exemplo, que surgiram nas proas das barcas, como meio eficaz de salvaguardá-las de tempestades e desgraças, e como a maneira segura de esconjurar espíritos maléficos, moradores do rio, que, de noite, saíam das profundas do Velho Chico para assombrar barqueiros, tentar mulheres, roubar crianças. Vendo as carrancas nas proas, de olhos esbugalhados, de bocarras escancaradas, feitas agressivas e horrendas, de propósito, os duendes espantavam-se e recolhiam-se, trêmulos, ao lodo do rio $^{264}$.

Portanto, assim como o Rio Ribeira, o rio São Francisco também era habitado por seres encantados, que podiam ser descritos como "duendes do rio"265. Esses duendes também habitavam o pantanal mato-grossense. Francisco Alexandre Ferreira Mendes coletou uma história sobre um negro d'água, definido como um "duende da tradição cuiabana", muito semelhante às narradas no Vale do Ribeira ${ }^{266}$. Brincalhão, o negro d'água vivia no rio Cuiabá e vivia pregando peças nos incautos pescadores locais, "[...] enganando-os nos puxões e furtando-lhes a isca dos anzóis no fundo do poço. Raras vezes era visto e quando anoitecia, era à meia-tinta da luz do ocaso, sempre dando cambalhotas na água, ou saltando de cima das lages, que ali existiam"267.

Certa noite, distraindo-se devido ao suculento biscate preso no anzol que um pescador lançara e, a um puxão violento, "[...] deixou-se inadvertidamente ferrar-se com o grande gancho farpado, que lhe varou a palma da mão esquerda, pela

\footnotetext{
${ }^{262}$ VALLADARES, 1971 e 1972 apud PARDAL, op. cit., p. 70.

${ }^{263}$ VALLADARES, 1959 apud PARDAL, op. cit., p. 70.

${ }^{264}$ MAIA, 1959 apud PARDAL, op. cit., p. 69.

${ }^{265}$ Outros mitos aquáticos existentes no Rio Ribeira também estão presentes no rio São Francisco, como a mãe d'água, o cavalo d'água e o cachorro d'água.

${ }^{266}$ MENDES, Francisco Alexandre Ferreira. Folclore Mato-grossense. Edição da Fundação Cultural do Mato Grosso, 1977, p. 33-35.

${ }^{267}$ Ibid., p. 33-35.
} 
agilidade do caboclo pescador"268. Foi retirado do rio. Ele era "[...] um autêntico garoto, o corpo completamente negro, luzidio e limoso, que escorregava das mãos dos pescadores que tentavam segurá-lo, como se fosse uma enguia repelente"269. $\mathrm{O}$ negro d'água foi amarrado e atirado no fundo da canoa para ser levado ao padre Ernesto Camilo Barreto, "[...] que àquela hora deveria estar ainda acordado, em orações na capela do Colégio" ${ }^{270}$. A canoa descia o rio quando, "[...] junto ao estirão da cachoeira, ao embate das ondas, soçobrou a embarcação entre duas lages e o negrinho d'água escapuliu-se no torvelinho agitado da corredeira, sumindo-se para sempre nas profundezas do rio"271. O evento ocorrido acabou servindo de lição ao negro d'água. Ele nunca mais foi visto. Deixou em paz os redeiros e os pescadores do rio.

Entre as similaridades dos negros d'água do Rio Ribeira e do rio Cuiabá, podemos apontar o temperamento brincalhão e o corpo de garoto dos negros d'água. Outros elementos observados no Rio Ribeira também estão presentes na narrativa do rio Cuiabá: a presença de um padre, o contato entre pessoas da terra e um negro d'água e a captura de um negro d'água. No entanto, diferentemente da vasta descendência gerada através do contato entre negros d'água e pessoas da terra no Rio Ribeira, no rio Cuiabá, pelo menos nessa narrativa, o contato foi efêmero e não gerou frutos: "Foi assim que pela primeira vez, única aliás, dois pescadores conseguiram apanhar o negrinho d'água, tão decantado, que devido à imprevidência deixaram escapar" 272 .

\footnotetext{
${ }^{268}$ MENDES, 1977 , p. 33-35.

${ }^{269}$ Ibid., p. 33-35.

${ }^{270} \mathrm{Em} \mathrm{1879,} \mathrm{o} \mathrm{padre} \mathrm{Enesto} \mathrm{Camilo} \mathrm{Barreto} \mathrm{lançou} \mathrm{as} \mathrm{bases} \mathrm{do} \mathrm{colégio} \mathrm{"São} \mathrm{João} \mathrm{Batista"} \mathrm{na}$ margem esquerda do rio Cuiabá, sete quilômetros a montante do porto da cidade, quase à frente da barra do ribeirão Pari. Assim, o fato deve ter ocorrido não muito distante dessa data. Quanto ao local, Mendes informou que o "negrinho d' água" foi capturado à montante do citado colégio. (MENDES,1977, p. 33-35).

${ }^{271}$ Ibid., p. 33-35.

${ }^{272}$ Ibid., p. 33-35.
} 


\subsection{Seres d’água no Brasil}

Nas águas brasileiras, europeus, africanos e indígenas inscreveram e mesclaram suas crenças e mitos. Assim, temos no Brasil uma extensa mitologia das águas, abrangendo mitos relacionados aos mares, rios, lagoas, fontes e chuva.

Um dos primeiros seres aquáticos descritos pelos cronistas coloniais foi o Ipupiara. Em 1560, José de Anchieta relatou que o Ipupiara era um fantasma que morava nas águas e matava os indígenas. Gândavo informou que, no ano de 1564, em São Vicente, foi morto com uma espada um monstro marinho que os indígenas chamavam de Hipupiara, que significava demônio-d'água ${ }^{273}$. No começo do século XVII, Frei Vicente do Salvador também observou a existência de "homensmarinhos"274. O jesuíta Fernão Cardim descreveu a aparência e os hábitos dos Ipupiaras machos e fêmeas. O Ipupiara macho possuía boa estatura e olhos demasiadamente encovados. As fêmeas eram muito formosas e tinham o cabelo comprido. Suas vítimas eram abraçadas e beijadas até a morte. Muitas, após esse abraço, ficavam em pedaços. Algumas vítimas, que ainda estavam inteiras, tiveram as seguintes partes dos seus corpos devoradas - olhos, narizes, pontas dos dedos dos pés e mãos e genitálias. Gabriel Soares de Souza, em 1587, também apontou a presença dos Ipupiaras, descritos como "homens marinhos", nos recôncavos da Bahia. Conforme Cascudo: "[...] o documentário dos sécs. XVI e XVII não registrou no Brasil outro ente marinho, com forma humana, além do Ipupiara, bestial, faminto, repugnante, de ferocidade primitiva e bruta" 275 .

No século XIX, apareceram as primeiras menções sobre a presença de um ser encantado muito importante para a mitologia do Pará e do Amazonas, o boto ${ }^{276}$. Esse animal sedutor, nas primeiras horas da noite, transformava-se num rapaz bonito, alto e branco. Frequentava bailes, onde seduzia e engravidava as moças ribeirinhas. Antes da madrugada, pulava na água e voltava a sua forma aquática ${ }^{277}$.

\footnotetext{
${ }^{273}$ CASCUDO, 1998, p. 459.

274 lbid., p. 459.

275 lbid., p. 460.

${ }^{276}$ Para Cascudo, o boto sedutor é um mito de convergência européia.

277 Ibid., p. 181.
} 
Para Couto de Magalhães, Uauiará, um deus tupi, transformava-se no boto ${ }^{278}$ sedutor:

\begin{abstract}
Nenhum dos seres sobrenaturais dos indígenas forneceu tantas lendas à poesia americana como o Uauiará. Ainda hoje no Pará não há uma só povoação do interior que não tenha para narrar ao viajante uma série de histórias, ora grotescas e extravagantes, ora melancólicas e ternas, em que ele figure como herói. O Uauiará é um grande amador das nossas índias; muitas delas atribuem seu primeiro filho a alguma esperteza desse deus, que ora as surpreendeu no banho, ora transformou-se na figura de um mortal para seduzi-las; ora arrebatou-as para debaixo d'água, onde a infeliz foi forçada a entregar-se a ele ${ }^{279}$.
\end{abstract}

Outro mito amazônico bastante popular é o da serpente d'água Boiúna, também chamada de Mãe d'água ou Cobra Grande ${ }^{280}$. Para Cascudo, a Boiúna "[...] ataca para matar, sem a menor intervenção sexual. Para ela convergiu o mito da mãe d'água, despido de suas formas sugestivas de beleza, canto e amor. A mãe d'água Boiúna é a dona das águas do rio"281. Descrita como mágica, polifórmica, aterradora, segundo Cascudo, o mito da Cobra Grande é o mais poderoso e complexo das águas amazônicas. Tem a forma de uma jibóia ou sucuriju. Após adquirir um grande volume, abandona a floresta e passa a viver no fundo do rio $^{282}$. Para assustar e engolir os ribeirinhos, transforma-se nas mais diferentes figuras, como em navios, vapores e canoas. Pode tomar a forma de um Navio Fantasma, descrito como um navio macabro, cujos "mastros, as vergas, as caranguejas são tíbias, fêmures, costelas de esqueletos dos fugidos das campas" ${ }^{283}$, que navega pelas águas, apavorando a população ribeirinha.

Os povos africanos também contribuíram para a nossa mitologia das águas. Quanto aos africanos oriundos da Costa da Guiné, Arthur Ramos frisou os seguintes orixás do complexo cultural jeje-iorubano: Olokum (deus do mar), Oloxá (deusa dos lagos), Oiá (deusa do Oiá), Oxum (deusa do rio Oxum) e Obá (deusa do rio Obá) ${ }^{284}$.

\footnotetext{
${ }^{278} \mathrm{Em} \mathrm{1865}$, Luís Agassiz relatou que encontrou um boto mutilado pelos indígenas, que usavam as nadadeiras para curar doenças e os olhos para conquistar o afeto da pessoa amada. Cascudo também apontou que o "[...] olho do boto, seco, é um amuleto de incrível eficácia amorosa." (CASCUDO, 1998, p.183).

279 Ibid., p. 182.

280 Ibid., p. 173 - 174.

${ }^{281}$ Ibid., p. 173.

282 Ibid., p. 290

283 Ibid.,p. 174.

${ }^{284}$ RAMOS, Arthur. O folclore negro do Brasil: demopsicologia e psicanálise. $3^{\mathrm{a}}$ ed. São Paulo: Martins Fontes, 2007.
} 
Nina Rodrigues ressaltou que, no Brasil, na falta do rio Oxum, a orixá Oxum converteu-se na divindade das fontes e regatos. Na falta do rio Oiá, a orixá Oiá transformou-se na deusa das tempestades e tormentas ${ }^{285}$. Ainda temos uma deusa das chuvas, Nanã, a mais velha das deusas das águas africana ${ }^{286}$. Enquanto Oxum é a divindade das águas doces, lemanjá, a mais prestigiada entidade feminina dos candomblés da Bahia, é a deusa das águas salgadas ${ }^{287}$. lemanjá, nascida do casamento entre Obaalé, o Céu, com Odudua, a Terra ${ }^{288}$, também é conhecida por Janaína, Dona Janaína, Princesa do Mar, Sereia do Mar, Dona Maria e Rainha do Mar $^{289}$. Em Salvador, lemanjá mora no Dique, um lago existente no caminho do rio Vermelho ${ }^{290}$. Há uma festa em sua homenagem no dia 02 de fevereiro, na qual são oferecidos os mais variados presentes à Rainha do Mar.

Quanto à contribuição dos povos da África Centro-Ocidental à mitologia das águas brasileiras, destaca-se o culto aos "espíritos das águas". Henri Chatelain, ao recolher contos angolanos, observou a existência de uma variedade de "espíritos das águas", os quais podiam ser chamados de Kianda, Kiximbi, Lucala, Cuanza e $K_{\text {Kituta }}{ }^{291}$. Robert Slenes também assinalou a crença generalizada nos "espíritos das águas" na África Centro-Ocidental e destacou que seu culto assegurava o bem-estar da comunidade ${ }^{292}$.

Os portugueses também colaboraram com a mitologia das águas brasileiras. Como ressaltou Cascudo, "[...] os portugueses, homens do mar, possuíam a tradição das lendas marítimas, de tritões, sereias e animais fabulosos"293. A sereia era metade peixe e metade mulher e, com o seu canto, seduzia navegantes e pescadores. Desejando unirem-se às sereias, eles atiravam-se às águas e morriam

\footnotetext{
${ }^{285}$ Alguns chamam essa orixá de lansã. (RODRIGUES, Nina. Os africanos no Brasil. Brasília: Editora da Universidade de Brasília, 2004, p. 255).

${ }^{286}$ CARNEIRO, Edson. Religiões Negras: notas de etnografia religiosa. Rio de Janeiro: Civilização Brasileira, 1936, p.47

${ }^{287}$ CASCUDO, 1998, p.448.

${ }^{288}$ RAMOS, 1998, p. 11.

289 CASCUDO, op. cit., p. 448.

290 Ibid., p. 40.

291 CHATELAIN, Henri. Contos Populares de Angola: cinquenta contos em quimbundo. Lisboa: Agência do Ultramar, 1964, p.52.

292 SLENES, R. The Great Porpoise-Skull. In: HEYWOOD, Linda M. (Ed.). Central Africans and Cultural Transformations in the American Diaspora. Cambridge: Cambridge University Press, 2002, p. 194.

${ }^{293}$ CASCUDO, Camara. Geografia dos Mitos Brasileiros. São Paulo: Global, 2002, p. 56.
} 
afogados $^{294}$.

Em muitos mitos brasileiros, não é possível identificar uma matriz cultural predominante. Esse é o caso do mito do João Galafuz (Pernambuco), ou João Galafoice (Alagoas), ou Jean de la foice (Sergipe), descrito como um duende marinho que, com um facho luminoso, em certas noites, emerge das ondas e prenuncia tempestades e naufrágios ${ }^{295}$. Assim, com múltiplas contribuições, há uma infinidade de habitantes nas águas brasileiras, como os Companheiros do Fundo, o Cavalo do Rio e tantas Cobras d'água.

Além dos seres encantados, nas águas brasileiras também existiriam cidades submersas, procissão de afogados e barcas assombradas. Há muitos mitos sobre a origem das águas do mar, dos rios e das lagoas. Também existem muitas simpatias com as águas, como a crença de que não se deve beber água com chapéu na cabeça. As águas também são usadas em práticas de cura e adivinhação. São importantes em vários rituais religiosos, como na "Lavagem" da Igreja do Senhor do Bonfim.

Dessa forma, podemos observar que a mitologia das águas no Brasil é bastante expressiva.

${ }^{294}$ CASCUDO, 1998, p. 817.

${ }^{295}$ Ibid., p. 482. 


\section{Capítulo 3 - Travessia Atlântica}

Entre os séculos XVII e XIX, o Vale do Ribeira recebeu africanos. Os primeiros aportaram no Vale do Ribeira no século XVII. Primeiramente, foram enviados às minas. Num momento posterior, a lavoura arrozeira passou a ser o seu principal destino.

Os comerciantes do Vale do Ribeira buscavam os cativos no Rio de Janeiro. Os africanos procediam, principalmente, da África Centro-Ocidental. Isso é o que mostram os Maços de População de Xiririca para o ano de 1806. Apesar de a maioria dos escravizados dessa localidade ser nascida no Brasil, trinta e dois cativos eram africanos. Desse total, trinta e um eram provenientes da África CentroOcidental (doze cativos oriundos de Angola, dezoito de Benguela e um do Congo $)^{296}$. A procedência dos cativos de Xiririca no começo do século XIX confirma os dados obtidos por Robert Slenes, segundo os quais, nesse período, a maioria dos escravizados do centro-sul brasileiro era oriunda da África Centro-Ocidental ${ }^{297}$. Mesmo num período anterior, dada a intensidade e a relevância do comércio escravista na África Centro-Ocidental, a maioria dos africanos levados ao Vale do Ribeira também era proveniente dessa região.

\footnotetext{
${ }^{296}$ PAES, Gabriela Segarra Martins. A Recomendação das Almas na Comunidade Remanescente de Quilombo de Pedro Cubas. 2007. Dissertação (Mestrado em História) - Faculdade de Filosofia, Letras e Ciências Humanas da Universidade de São Paulo, São Paulo, 2007, p. 35.

${ }^{297}$ SLENES, Robert W. Malungo, Ngoma vem: África coberta e descoberta no Brasil. Revista USP, São Paulo, n. 12, 1991/92, p. 215. 


\subsection{O Rio Cuanza e a Escravidão Atlântica}

Em 1485, o rei de Portugal, D. João II, enviou o navegador português Diogo Cão ao estuário do rio Zaire ${ }^{298}$. Após desbravar mares, esse expedicionário aportou na foz do rio Zaire, na Província de Soyo, pertencente ao Congo. Formado por um conjunto de províncias, o Congo abrangia uma extensa região da África CentroOcidental. As províncias eram governadas por chefes, os quais eram encarregados de coletar impostos e tributos e enviá-los ao mani Congo $^{299}$. Existiam grandes mercados regionais no reino, nos quais circulavam sal, metais, tecidos, derivados de animais, cativos, entre outros itens ${ }^{300}$.

Desde antes da chegada dos portugueses, o Congo estava passando por um processo de expansão. As guerras contra outros povos eram frequentes e produziam cativos. Duas importantes feitorias que comercializavam cativos para o além-mar, já na primeira metade do século XVI, na costa Atlântica, eram Pinda, na foz do rio Congo, e Loango, ao norte. O mercado de cativos era controlado pelo mani Congo. Para escapar desse monopólio e dado o aumento da demanda atlântica por cativos, Portugal voltou seus olhos para o Dongo, localizado ao sul do Congo ${ }^{301}$.

O Dongo, chefatura antes subordinada ao Congo, estendia-se do rio Bengo até a foz do rio Cuanza. Portugal buscava metais preciosos, no entanto, como as expectativas quanto à existência de metais não se concretizaram, foi a aquisição de cativos que motivou a permanência lusitana na região ${ }^{302}$. Para isso, Portugal precisava controlar as rotas de comércio de escravos. A estratégia adotada foi o controle do rio Cuanza. Em 1575, nas proximidades da foz do rio, os portugueses fundaram a colônia de São Paulo de Loanda ${ }^{303}$. Em seguida, foram edificadas mais três feitorias ao longo do Cuanza: Muxima, Massangano e Cambambe. Com o passar dos anos, foram erigidas novas feitorias lusitanas ao longo desse rio. Esse

\footnotetext{
${ }^{298}$ SOUZA, Marina de Mello. Reis Negros no Brasil escravista: História da Festa da Coroação de Rei Congo. Belo Horizonte: Ed. UFMG, 2002, p. 52.

${ }^{299}$ Mani Congo é o título do chefe do Congo.

${ }^{300}$ SOUZA, 2002, p. 47.

301 lbid., p 74-75.

${ }^{302}$ HEINTZ, 2007, p. 278-279

${ }^{303}$ SOUZA, op. cit., p. 74, 75, 103 e 124.

89
} 
conjunto de feitorias portuguesas delineava o que passou a ser chamado de Angola.

O rio Cuanza era suficientemente largo para permitir que navios trafegassem pelas suas águas. Referindo-se ao período entre os anos de 1585 e 1660, Thornton e Heywood afirmaram:

Both the Congo and the Kwanza were broad enough to allow ships to penetrate into the interior until they reached a fall line in the highlands though during this period the Kwanza was more often used as a shipping corridor linking highlands and the Atlantic than was the Kongo ${ }^{304}$.

Diferentemente dos autores acima citados, Miller enfatizou a estreiteza dos rios africanos. Afirmou que numerosos rios africanos que desaguavam no oceano eram pouco profundos e não se alargavam para dimensões navegáveis até se aproximarem muito da costa. Segundo esse pesquisador: "[...] mesmo os maiores rios - o Congo, o Kwanza e o Kunene, permitem à navegação oceânica penetrar apenas 160 quilômetros ou ainda menos"305. Parreira destacou que o rio Cuanza era navegável até a feitoria de Massangano ${ }^{306}$.

Muitos rios da África Centro-Ocidental sofriam com as chuvas, as quais aumentavam drasticamente os caudais dos rios e provocavam inundações, transformando as margens em pântanos intransitáveis ${ }^{307}$. Assim, com exceção do rio Cuanza, os caminhos não eram ribeirinhos, nem paralelos aos grandes caudais de água. Principal via de transporte ${ }^{308}$, "chave da conquista", Cadornega "[...] never tires of describing it and its traffic, and he tells many stories and recounts many events which had taken place on, or along, this river"309.

O comércio de cativos, embarcados nas proximidades da foz do rio Cuanza, em Luanda, tornou-se uma atividade econômica de grande envergadura e

\footnotetext{
${ }^{304}$ THORNTON, John K.; HEYWOOD, Linda M. Central Africans, Atlantic Creoles and the Foundation of the Americas, 1585-1660. Cambridge: Cambrigde University Press, 2002, p. 52.

${ }^{305}$ MILLER, Joseph C. Poder político e parentesco: Os antigos estados mbundu em Angola. Trad. de Maria da Conceição Neto. Luanda: Arquivo Nacional/ Ministério da Cultura, 1995, p. 31-32

${ }^{306}$ PARREIRA, Adriano. Economia e Sociedade em Angola na Época da Rainha Jinga, Século XVII. Lisboa: Editorial Estampa, 1997, p. 196.

${ }^{307}$ Ibid., p. 20.

308 HEINTZ, Beatrix. Angola nos séculos XVI e XVII. Estudo sobre fontes, métodos e história. Tradução Marina Santos. Luanda: Kilombelombe, 2007, p. 278-279.

${ }^{309}$ CHILDS, Gladwyn Murray. The People of Angola in the Seventeenth Century according to Cadornega. The Journal of African History, vol. 1, n.2, 1960, p. 1. 
complexidade $^{310}$. A ampliação do comércio de cativos possibilitou que Angola deixasse de ser a periferia do Congo e passasse a ser uma área prioritária para os portugueses $^{311}$. Cadornega destacou a elevada quantidade de cativos que partiam de Luanda e também a origem distante de muitos deles, afirmando que o sertão era "a mais rica mina de Angola" ${ }^{312}$.

Angola era vista como um grande reservatório de cativos ${ }^{313}$. Por outro lado, em Portugal, em meados do século XVII, membros do Conselho Ultramarino elaboraram um relatório afirmando não existir reserva de mão-de-obra indígena no Brasil, sendo assim, "[...] o Conselho entendia que só o trato de escravos de Angola podia 'conservar' o Brasil"314. O Brasil despontava como emergente colônia produtora de açúcar e para isto Angola tornava-se indispensável. A aquisição de escravizados para o Brasil passou a ser uma das prioridades da política portuguesa para Angola. Fundada no escravismo, a colonização portuguesa desenhou um espaço aterritorial composto por uma área de produção escravista, localizada no litoral da América do Sul, e uma área de reprodução de cativos, centrada em Angola $^{315}$. Assim, Brasil e Angola, "[...] duas partes unidas pelo oceano se completam num só sistema de exploração colonial" ${ }^{316}$.

Angola e Brasil estavam tão entrelaçados que, quando os holandeses decidiram controlar a economia açucareira, ambas as localidades entraram na sua mira. Em 1630, a Holanda conquistou Pernambuco e, em seguida, toda a região açucareira acima do rio São Francisco. Em 1641, foi a vez dos holandeses desembarcarem em Luanda. Por sua vez, Portugal centrou esforços para restaurar a soberania sobre as duas colônias. Em 1654, os holandeses foram expulsos do território brasileiro. Antes disso, em 1647, Salvador Correa de Sá e Benevides comandara as forças militares que expulsaram os holandeses de Angola e promoveram a restauração portuguesa. Em seguida, assumiu o cargo de governador

310 Cavazzi relatou que o rio Cuanza desaguava no oceano a 12 léguas de Luanda. (MONTECÚCCOLO, Padre João Antonio Cavazzi de. Descrição histórica dos três reinos do Congo, Matamba e Angola. 2 Volumes. Tradução, notas e índices pelo padre Graciano Maria de Leguzzano. Lisboa: Junta de Investigação do Ultramar, 1965, livro primeiro, p. 22).

${ }^{311}$ MILLER, op. cit., p. 219.

${ }^{312}$ SOUZA, 2002, p. 128.

${ }^{313}$ Ibid., p. 288.

${ }^{314}$ ALENCASTRO, Luiz Felipe. O Trato dos Viventes: A Formação do Brasil no Atlântico Sul. São Paulo: Companhia das Letras, 2000, p. 40 - 41.

${ }^{315}$ ALENCASTRO, op. cit., p. 09.

${ }^{316}$ Ibid., p. 09. 
de Angola. Muito prestigiado na corte portuguesa, fazia parte do Conselho Ultramarino e possuía vínculo direto com o comércio escravista ${ }^{317}$. Transitou por diversas posições dentro do Império português e, em 1658, foi nomeado para um novo cargo do outro lado do Atlântico, "Administrador das Minas", com jurisdição sobre as capitanias de São Paulo, Rio de Janeiro e Espírito Santo ${ }^{318}$.

As atividades de Salvador Correa de Sá e Benevides, nos dois lados do Atlântico, sugerem laços estreitos entre Angola e a mineração nas capitanias de São Paulo, Rio de Janeiro e Espírito Santo. Note-se que, nessa época, em meados do século XVII, as minas além-Mantiqueira não tinham sido descobertas. O Vale do Ribeira era um dos principais locais de exploração aurífera. Assim, esses fatos parecem apontar para Angola como um dos locais de embarque de muitos cativos que aportaram no Ribeira.

$\mathrm{Na}$ primeira metade do século XVII, grande parte da pujança do comércio escravista foi devida à aliança firmada entre os portugueses e os imbangalas. Originários do interior do continente, do Reino Lunda, situado na margem leste do rio Kasai, os imbangalas eram guerreiros nômades extremamente bem-sucedidos na guerra, na caça e no comércio escravista. A unidade do grupo era garantida através de uma ideologia guerreira ${ }^{319}$. À medida que marchavam em direção à costa, incorporavam novas instituições. Uma dessas instituições foi uma organização de guerreiros chamada kilombo. Funcionando como uma máquina de guerra, o kilombo recrutava seus novos integrantes entre as populações subjugadas. As crianças não circuncidadas dessas populações, depois de passarem por ritos de iniciação, tornavam-se membros do kilombo.

Temidos e solicitados, tornaram-se aliados dos portugueses. Essenciais aos interesses lusitanos, a oportunidade de lutar ao lado dos imbangalas influenciava as decisões estratégicas, como a localização das feitorias portuguesas ${ }^{320}$. Em tempos de paz, capturavam e escravizavam os povos locais, e, em tempos de guerra oficial

\footnotetext{
${ }^{317}$ Ibid., p. 41.

${ }^{318}$ TAQUES, Pedro. Notícias das Minas de S. Paulo e dos sertões da mesma Capitania. S. Paulo: Martins, 1954, p. 45.

${ }^{319}$ HEINTZ, 2007, p. 281.

${ }^{320}$ MILLER, Joseph C. Poder político e parentesco. Os antigos estados mbundu em Angola. Tradução Maria da Conceição Neto. Luanda: Arquivo Nacional/ Ministério da Cultura, 1995, p. 219. 
declarada, juntavam-se aos exércitos portugueses ${ }^{321}$. Na década de 1610, os imbangalas deram às expedições portuguesas os seus primeiros sucessos expressivos contra os ambundos - povos locais que habitavam a região banhada pelo rio Cuanza ${ }^{322}$. Saíam anualmente de Luanda como resultado dessa política de aliança, nos finais do segundo decênio do século XVII, cerca de 12.000 cativos, os quais desembarcaram no Peru e no Brasil ${ }^{323}$.

As "relações estreitas, quase de simbiose" entre imbangalas e portugueses, verificadas ao norte do Cuanza, contrastavam com a hostilidade entre ambos ao sul. Enquanto a hostilidade entre imbangalas e a população local (os ambundos) contribuiu para a aliança dos imbangalas com os portugueses ao norte, ao sul do Cuanza, a maior afinidade entre imbangalas e a população local (os ovimbundos) permitiu que os imbangalas permanecessem independentes da interferência européia. Os portugueses, porém, não desistiram de ali estabelecer o mesmo tipo de relação existente com os imbangalas ao norte do Cuanza. No entanto, nas ocasiões em que um acordo foi estabelecido, os imbangalas não se mostraram parceiros estáveis. Apenas no final do século XVII, os imbangalas do sul passaram a ser mais cooperativos com os portugueses e com o comércio de cativos $^{324}$.

No começo do século XVII, imbangalas do norte e portugueses se voltaram contra o Dongo - o principal fornecedor de cativos embarcados em Luanda. Luís Mendes de Vasconcelos, governador de Angola entre os anos de 1617 e 1621 , promoveu uma campanha militar contra Ngola a Mbande ${ }^{325}$, o chefe do Dongo ${ }^{326}$. Em 1624, Ngola a Mbande foi assassinado em circunstâncias misteriosas, pairando a suspeita do envolvimento de Jinga, sua irmã. Em seguida, Jinga apresentou-se como regente em nome do seu sobrinho. Após assassinar este último e jogar seu corpo no rio Cuanza, ela apresentou-se como legítima herdeira ao trono do Dongo $^{327}$. No entanto, Fernão de Souza, governador de Angola entre os anos de 1624 e 1630, mobilizou-se para que o trono do Dongo fosse ocupado por Are a Quiluange, chefe da região de Pungo Andongo. Em 1626, após aceitar ser vassalo

\footnotetext{
${ }^{321}$ PARREIRA, 1997, p. 192.

${ }^{322}$ MILLER, op. cit., p. 219.

${ }^{323}$ PARREIRA, 1997., p. 184.

${ }^{324}$ MILLER, 1995, p. 207- 213.

${ }^{325} \mathrm{HEINTZ,} \mathrm{2007,} \mathrm{p.} 284$.

${ }^{326} \mathrm{Ngola}$ a Mbande detinha o título ngola a kiluanje - posição dominante entre os ambundos.

${ }^{327}$ MONTECÚCCOLO, 1965, vol. 2, p. 71. 
do rei de Portugal, Are a Quiluange foi declarado rei do Dongo. Jinga e os chefes locais foram intimados a reconhecer o novo rei e a ele submeterem-se, mas Jinga recusou-se a assumir uma relação de vassalagem em relação ao rei de Portugal e conseguiu o apoio das chefaturas locais ao longo do rio Cuanza. Os portugueses declararam guerra a Jinga, que se refugiou nas ilhas do rio Cuanza, onde se concentravam as forças de resistência representadas por ela e pelos chefes do rio Cuanza. Quando as tropas portuguesas atacaram essas ilhas, Jinga conseguiu fugir. Em outubro de 1626, após Are a Quiluange ter morrido de varíola, seu meio irmão, Ngola a Are, foi investido como vassalo do rei de Portugal e declarado rei do Dongo ${ }^{328}$.

Jinga foi acolhida por um imbangala (Jaga Casa Cangola), tornando-se sua esposa e tembanza, ou seja, sacerdotisa de importante rito dos imbangalas. Associada aos imbangalas, Jinga passou, aproximadamente, vinte anos em escaramuças pela região do rio Cuanza e do rio Lucala ${ }^{329}$ - principal afluente do rio Cuanza na margem norte e linha divisória entre Angola e Matamba ${ }^{330}$. Porém, não renunciou ao trono do Dongo ${ }^{331}$. Tornou-se muhongo ${ }^{332}$ de Matamba $^{333}$, região situada a leste do Dongo e, assim como esse reino, também habitada por povos Ambundo. Conforme Cavazzi:

[...] em tempos passados muitas províncias do reino do Congo se separaram dele e constituíram o reino de Matamba e Dongo. Os Portugueses, que conquistaram grande parte do Dongo, chamando-lhes Angola, deixaram o resto sob a autoridade dos reis que antes dominavam ambas as regiões, de maneira que Jinga podia pretender o domínio de Matamba, por os seus predecessores terem dominado o conjunto de Matamba e Dongo ${ }^{334}$.

Os portugueses não desistiram de exigir a submissão de Jinga. Porém, com o aparecimento dos holandeses, a autoridade dos portugueses erodia-se no interior do

\footnotetext{
${ }^{328}$ HEINTZ, 2007, p. 322-352.

${ }^{329}$ SOUZA, Marina de Mello. A rainha jinga de Matamba e o catolicismo - África Central, século XVII. In: Las relaciones discretas entre las Monarquias Hispana y Portuguesa: Las Casas de Las Reina (siglos XV-XIX). Madri: Polifemo, 2009, p. 164.

${ }^{330}$ MONTECÚCCOLO, 1965, vol. 2, p. 108.

${ }^{331}$ HEINTZ, op. cit., 366-368.

${ }^{332}$ Título da governante de Matamba.

${ }^{333}$ Para Adriano Parreira, o trono de Matamba "[...] não foi uma 'escolha' deliberada de Jinga. A realidade era bem mais amarga para ela. Longe de ser uma "escolha", a ocupação de Matamba foi porventura a única e derradeira alternativa que lhe restou." (PARREIRA, 1997, p. 181).

${ }^{334}$ MONTECÚCCOLO, op. cit., vol. 2, p. 78-79. 
continente $^{335}$. Ademais, Jinga não só não aceitou se submeter aos portugueses, como também se aliou aos seus inimigos europeus. A aliança com os holandeses contribuiu para a independência de Jinga em relação aos portugueses. Ao comercializar cativos diretamente com os holandeses, Jinga adquiria mercadorias européias independentemente de suas relações com as autoridades de Luanda ${ }^{336}$. E foram muitos cativos, já que Jinga dominava as redes escravistas vindas do interior. Durante a década de 1630, através do território ndembu, desenvolveu-se uma rota escravista de Matamba até os holandeses no litoral ${ }^{337}$. Jinga dominou "[...] parte do território Mbaka, o Oando e o país Ndembu, porventura o mais importante espaço econômico da África Central ocidental alguma vez submetido a uma só autoridade" ${ }^{338}$. A quantidade de cativos era tão abundante que Jinga foi elevada à estatura de mais poderosa governante do interior ${ }^{339}$.

No entanto, com a expulsão dos holandeses, em 1648, o jogo de forças alterou-se novamente. Jinga e as autoridades portuguesas em Angola aproximaramse e acabaram firmando um acordo de paz ${ }^{340}$. A estabilização do comércio $^{341}$ na região permitiu o alargamento da influência militar e, consequentemente, a conquista de novos mercados, em benefício tanto das autoridades de Matamba quanto dos portugueses $^{342}$. Jinga, porém, em relação à época da presença holandesa, enfraqueceu-se, pois perdera a supremacia em relação às rotas do interior. 0 aumento da atividade dos exércitos portugueses no corredor do rio Cuanza levou ao "[...] crescimento do volume de negócios em Kassanji, que segundo algumas fontes foi o pumbo mais procurado e o 'mais importante do sertão"'343. Os mercados de Matamba e Kassange, nas décadas de 1630 e 1640, tornaram-se os maiores fornecedores de cativos para o comércio transatlântico e, também, os maiores

\footnotetext{
${ }^{335}$ HEINTZ, op. cit., p. 333.

${ }^{336}$ MILLER, 1995, p. 205.

${ }^{337}$ Ibid., p. 205.

${ }^{338}$ PARREIRA, 1997, p. 201.

${ }^{339}$ MILLER, op. cit., p. 205.

${ }^{340}$ PARREIRA, op. cit., p. 201.

${ }^{341}$ A estabilização do comércio após o acordo de paz entre Jinga e as autoridades de Angola também permitiu que os portugueses preparassem com minúcia uma batalha contra o rei do Congo. Assim, em 1665, foi travada a batalha de Ambuíla, a qual foi perdida pelo rei do Congo e marcou o momento decisivo da derrocada do seu reino (PARREIRA, op. cit., p. 201).

${ }^{342}$ Ibid., p. 201.

${ }^{343}$ lbid., p. 119. 
consumidores das mercadorias européias na África Centro-Ocidental ${ }^{344}$.

Quanto ao território de conquista portuguesa, em 1626, quando Ngola a Are foi declarado chefe do Dongo, iniciou-se a fase de consolidação do domínio português sobre o reino do Dongo ${ }^{345}$. Em 1671, após a derrota final do Hari a Kiluange, em Pungo Andongo, os portugueses se consolidaram como conquistadores do território ${ }^{346}$.

Situado nas franjas da colônia portuguesa, Kassanje tornou-se um estado imbangala muito importante. E Kassanje não foi o único caso. Em meados do século XVII, ao redor de Angola, ao norte do rio Cuanza, foi formado um anel de novos estados comandados por imbangalas ${ }^{347}$. E esses estados traficantes estabelecidos em torno do território português dominaram a história política e econômica de Angola nos séculos XVIII e XIX ${ }^{348}$.

A aliança entre imbangalas e portugueses, ambos forasteiros, desequilibrou 0 antigo jogo de forças. Os antigos chefes foram derrotados e parte das populações locais escravizadas. Assim, com o estabelecimento dos portugueses e o comércio de gente na região durante os séculos XVII, XVIII e XIX, milhares de cativos oriundos da África Centro-Ocidental cruzaram o Atlântico e passaram a viver em vários locais na América. Um desses locais foi o Vale do Ribeira.

\footnotetext{
344 Ibid., p. 305.

${ }^{345}$ HEINTZE, op. cit. p. 352

${ }^{346}$ MILLER, 1995., p. 19

${ }^{347}$ Ibid., p. 199.

${ }^{348}$ Ibid., p. 259. 


\subsection{O Cuanza e o Ribeira}

$\mathrm{Na}$ África Centro-Ocidental, os grupos etnolinguísticos tendiam a acompanhar os principais cursos de água ${ }^{349}$. Dentre os grupos etnolinguísticos subjugados pelos imbangalas, merece destaque o dos Ambundo. Agricultores "sem qualquer motivação para se transformarem em guerreiros" ${ }^{350}$, possuíam o kimbundu como idioma ${ }^{351}$. Eles habitavam a região banhada pelo rio Cuanza, na área imediatamente ao norte do planalto de Benguela ${ }^{352}$. Possuíam o seguinte mito fundador: o mundo tinha começado quando os seus antepassados partiram da Kalunga, identificada como "a grande água" e pararam nos vales e colinas habitadas pelos seus descendentes ${ }^{353}$.

Os Ambundo organizavam-se em linhagens. Os chefes de linhagem veneravam uma insígnia chamada lunga, descrita por Miller como "[...] uma relíquia sagrada que assume formas físicas variadas, mas, geralmente, tomou a forma de uma figurinha humana talhada em madeira" ${ }^{354}$. Cada lunga "habitava" um rio ou lago, "[...] sob os cuidados dum dignitário que era o único a conhecer o segredo da comunicação com as forças espirituais" ${ }^{355}$. Uma insígnia era um objeto que estava associado a poderes sobrenaturais, acarretando, dessa forma, uma forma de autoridade aos seus detentores. Assim, os chefes das linhagens ambundos, guardiões do lunga, intermediários entre os vivos e os mortos, eram os detentores do poder. Determinavam como o território seria utilizado, autorizando mudanças de residência e selecionando locais para novas aldeias. Também localizavam fontes de água, traziam chuvas abundantes e forneciam um pó branco, pemba, para assegurar a fertilidade das mulheres. A autoridade deles estava relacionada à mulemba, árvore que os ambundos sempre plantavam e que garantia que o pemba tivesse efeito ${ }^{356}$.

\footnotetext{
${ }^{349}$ Ibid., op. cit., p. 32.

${ }^{350}$ PARREIRA, 1997, p. 181.

${ }^{351}$ Ibid., p. 161.

${ }^{352}$ Ibid., p. 161.

${ }^{353}$ MILLER, 1995,, p. 55.

${ }^{354}$ Ibid., p. 59.

${ }^{355}$ Ibid., p. 62.

${ }^{356}$ Ibid., p. 43-47. 
Havia uma rígida correspondência entre as posições lunga e a hidrografia do território ${ }^{357}$. Os guardiões do lunga controlavam "as chuvas que caíam na bacia hidrográfica de qualquer ribeiro ou rio ocupado pelo seu lunga", garantindo assim a fertilidade dos campos ${ }^{358}$. Os detentores dos malunga (plural de lunga) dos grandes rios se consideravam mais importantes que os detentores dos malunga dos afluentes $^{359}$.

Controlando o acesso a terra, aos rios, aos demais recursos naturais existentes e, também, garantindo uma boa colheita devido a um bom regime de chuva e à fertilidade das mulheres, esses chefes de linhagem, guardiões do lunga, exigiam respeito e, possivelmente, tributos da população ${ }^{360}$. Assim, esses chefes de linhagem passaram a deter títulos políticos e a dominar territórios ao redor de determinadas massas de água.

Num momento posterior, um novo tipo de estrutura política emergiu, baseada no ngola (objeto de ferro) como insígnia de linhagem ${ }^{361}$. O ferro estava associado simbolicamente ao poder e ao prestígio devido às suas características físicas (maleabilidade, resistência e durabilidade), as quais lhe conferiam uma posição de superioridade em relação aos outros materiais ${ }^{362}$. A insígnia ngola passou a ser dominante e os reis lunga foram eclipsados pelos reis $n g o l a^{363}$.

Esses ngola, além de estarem associados ao ferro, também estavam relacionados com as chuvas. Parreira destacou que, no Dongo, os chefes ngola eram considerados senhores da chuva, assim como os ferreiros ${ }^{364}$. Thornton relatou que, em 1575, o chefe do Dongo afirmou que era o senhor do sol e da chuva, podendo ordenar que chovesse ou não segundo o seu próprio desejo ${ }^{365}$.

Os reis ngola atingiram o auge do seu poder em meados do século XVI para, logo em seguida, nas primeiras décadas do século seguinte, serem subjugados por portugueses e imbangalas. No entanto, a influência dessas insígnias (ngola e lunga) perdura até os dias atuais. Ao pesquisar os ambundos modernos, Miller observou a

\footnotetext{
${ }^{357}$ Ibid., p. 94.

${ }^{358}$ Ibid., p. 62.

${ }^{359}$ lbid., p. 62.

${ }^{360} \mathrm{lbid} .$, p. 62.

${ }^{361}$ MILLER, 1995, p. 63.

${ }^{362}$ PARREIRA, 1997, p. 61.

${ }^{363}$ MILLER, op. cit., p. 88.

${ }^{364}$ PARREIRA, op. cit., p. 42.

${ }^{365}$ THORNTON, John. A África e os africanos na formação do mundo atlântico, 1400-1800. Trad. De Marisa Rocha Motta. Rio de Janeiro: Ed. Campus; Elsevier, 2000, p. 253-254. 
crença em numerosos "espíritos das águas" e afirmou que essa crença é amplamente sustentada em toda a África Central. Esse autor associou os "espíritos das águas" atuais aos antigos malunga. Atualmente, muitos lagos e rios são denominados com o nome do espírito que abrigaram em tempos idos. O missionário capuchinho Cavazzi, o qual pregou na África Centro-Ocidental no século XVII, afirmou que os ambundos acreditavam que os "espíritos das águas" viviam em outro lugar, mas se refugiaram nas águas quando os imbangalas chegaram.

Os imbangalas recrutavam seus combatentes entre a população subjugada e, dessa forma, absorveram etnias variadas. Incorporaram e adaptaram várias crenças dos ambundos, como as crenças nos "espíritos das águas". Os imbangalas acreditavam que seres sobrenaturais habitavam as nascentes dos rios. No século XVII, os imbangalas explicavam que

[...] a água que brotava dessas nascentes representava as lágrimas de espíritos, outrora grandes, que tinham ficado desgostosos porque seus seguidores humanos os tinham abandonado. As lágrimas dos espíritos femininos formavam os lagos da região e as dos espíritos masculinos tinham-se transformado em rios ${ }^{366}$.

Outra crença ligada às águas relacionava-se com o uso de poderes mágicos para aumentar o caudal do rio. Essa capacidade, atribuída aos reis, estava estreitamente associada às técnicas de fazer chover. Também havia o oposto e várias histórias abordavam episódios onde as águas de um rio foram apartadas, permitindo que o rio fosse atravessado. Segundo Miller: "Embora o estereótipo do apartar as águas se encontre por quase toda a parte no mundo, a amplitude dessa distribuição não retira importância à sua função específica no simbolismo dos Mbundu"367.

O missionário capuchinho Cavazzi, ao percorrer a região do rio Cuanza, observou a existência de vários altares e pequenas casas utilizadas em rituais de veneração ao rio. Em uma ocasião, na província de Haco (margem esquerda do Cuanza), deparou-se com uma casa próxima de uma cachoeira, cujo interior continha uma mesa com um peixe fresco e uma fogaça de sorgo. Tal visão despertou a ira do capuchinho, que lançou o peixe, a mesa, a fogaça e até a própria

\footnotetext{
${ }^{366}$ MILLER, 1995, p. 251.

${ }^{367}$ Ibid., p. 133. 
casa na cachoeira. Interrogou os pescadores, que the explicaram que, segundo a tradição, o "[...] rio Cuanza falou aos nossos antepassados, dizendo-lhes que, se desejassem pesca abundante, Ihe construíssem uma casa, tendo dentro uma fogaça e o primeiro peixe que apanhassem"368. Nesse relato, podemos perceber que Cavazzi testemunhou um ofertório aos espíritos do rio.

Em outra passagem de sua obra, Cavazzi novamente sublinhou que, quando os africanos queriam pescar, faziam votos e ofertas e, "[...] por isso, nas margens há sempre altares, casas e abrigos para os ídolos que presidem as águas". Cavazzi também descreveu uma cerimônia praticada pelos centro-africanos em "todas as travessias de rio". Antes de atravessá-lo, eles cumprimentavam as águas, pois acreditavam que "[...] o movimento é indício de vida também nas águas ou acreditando que é uma divindade qualquer quem as perturba, ou as acalma". Assim, suplicavam que lhes fosse concedido passar tranquilamente para a outra margem do rio. Depois, "[...] bebem um bocado e amassam um pouco de barro, com que traçam no peito alguns sinais misteriosos. Por fim, com maravilhosa segurança, lançam-se ao rio para o atravessar" ${ }^{369}$. Em outro trecho, Cavazzi afirmou que os centroafricanos veneravam rios e lagos. De acordo com o missionário:

\begin{abstract}
Logo que descobrem água de longe, prostram-se no chão para adorá-la, endereçam-lhe orações, oblações e votos para não serem incomodados por ela, para não sofrerem penas, para não sucumbirem às doenças e para serem socorridos nas suas dificuldades. Tudo isto vi eu mesmo ser praticado nas regiões de Bondo, de Malemba, perto da lagoa de Saxia e sobre as margens de outros rios ${ }^{370}$.
\end{abstract}

Ainda apontando para a importância dos espíritos das águas, Cavazzi relatou que "[...] no passado, os reis de Angola adoravam um tal calunga, que quer dizer 'mar' ou 'grande senhor'"'371. Também conforme Cavazzi, as águas eram utilizadas em cerimônias conduzidas por sacerdotes de ritos mágico-religiosos. Por exemplo, o nganga-itiqui (um dos vários tipos de sacerdotes de ritos mágicos-religiosos) "[...] depois da estação seca, recolhe a primeira água da primeira chuva para oferecê-la

\footnotetext{
${ }^{368}$ MONTECÚCCOLO, 1965, vol. 2, p. 129-130.

${ }^{369}$ MONTECÚCCOLO, 1965, livro primeiro, p. 118.

${ }^{370} \mathrm{Ibid}$., livro segundo, p. 215.

${ }^{371}$ Ibid., livro segundo, p. 214. 
aos deuses" como solução para a desventura ${ }^{372}$. Ntinu-a-maza, que significava "rei da água", era outro tipo de sacerdote. Ele lançava um recipiente aberto no rio, com o qual retirava amuletos, os quais eram vistos como capazes de curar qualquer doença $^{373}$.

Chatelain, ao pesquisar os contos populares da região de Luanda no século XX, também frisou a importância dos "espíritos das águas". Conforme esse autor:

\begin{abstract}
É Kianda, um dos espíritos mais populares da mitologia de Luanda. É o gênio da água, e preside ao mundo dos peixes, de que a população nativa de Luanda depende para o seu sustento. Daí a sua popularidade. As rochas em frente do Forte de São Miguel, em Luanda, são consagradas a Kianda e servem de altares, onde os nativos ainda hoje põem ofertas de comida... No dialecto de Mbaka este gênio da água é chamado Kiximbi e tem em todos os vales o nome do rio local. Assim, no vale do Lucala, as ofertas são feitas ao Lucala, no Vale do Cuanza, ao Cuanza. Outro nome de Kianda é Kituta $^{374}$.
\end{abstract}

Os "espíritos das águas" não eram importantes apenas para os ambundos. Robert Slenes destacou a importância dos "espíritos das águas" para diversos povos da África Centro-Ocidental. Relatou que os Bacongo (falantes do Kikongo) também acreditavam nos "espíritos das águas", os quais eram chamados de "simbi" (bissimbi no plural) pelos "Basundi" (falantes do kikongo que habitavam as margens do rio Zaire). Os Bampangu, vizinhos dos Basundi, chamavam-nos de "Kiximbi", igual aos falantes de Mbaka. Os Mayombe (falantes do kikongo que habitavam o norte do rio Zaire) denominavam-nos de "Simbi" ou "Kinda". Slenes ressaltou que "Indeed, the atributes of simbi/kisimbi/kinda among all these groups were essentially the same as those Chatelain describes for kisimbi/kianda"375.

Foram esses povos que compartilhavam um conjunto de idéias acerca dos "espíritos das águas", que atravessaram o oceano e passaram a viver em várias localidades da América, como no Vale do Ribeira ${ }^{376}$. Ao abordarem a travessia do

\footnotetext{
${ }^{372}$ Ibid., livro primeiro, p. 88.

${ }^{373}$ Ibid., p. 96.

${ }^{374}$ CHATELAIN, Henri. Contos Populares de Angola. Cinquenta contos em quimbundo. Lisboa: Agência Geral do Ultramar, 1964, p. 521.

375 SLENES, R. The Great Porpoise-Skull. In: HEYWOOD, Linda M. (Ed.) Central Africans and Cultural Transformation in the America Diaspora. Cambrigde: Cambrigde University Press, 2002, p. 192.

${ }^{376}$ Parreira destacou que, em 1640, o Brasil era "o melhor cliente do tráfico implantado na região 101
} 
Atlântico, os pesquisadores Mintz e Price destacaram que os africanos que aportaram na América não compuseram grupos imediatamente. Defenderam que, no início, eles formavam aglomerados ou multidões ${ }^{377}$. No entanto, apesar da heterogeneidade cultural, os africanos apresentavam princípios básicos amplamente compartilhados e existia uma herança africana generalizada, que foi fundamental para a criação de uma nova cultura em solo americano. Por isso, propunham a substituição da explicação das semelhanças formais pela comparação de pressupostos mais gerais, uma "herança generalizada" que gerou novas formas ${ }^{378}$.

Já Thornton afirmou que a diversidade cultural africana estava sendo exagerada $^{379}$. Com base na linguagem, afirmou que era possível dividir os escravizados que abasteceram o tráfico atlântico em apenas três zonas culturais: a Alta Guiné (estendia-se do rio Senegal até a área ao sul do Cabo Mount na atual Libéria), a Baixa Guiné (abrangia desde as lagoas da região ocidental da Costa do Marfim até Camarões) e a Costa de Angola (alongava-se até o Império Lunda na província Shaba, na atual República Democrática do Congo) ${ }^{380}$. Além disso, cada unidade linguística não encerrava uma cultura inteiramente diferente. Tanto a proximidade geográfica quanto as relações comerciais criaram similaridades culturais em regiões diversas. Segundo Thornton:

\begin{abstract}
Ademais, a linguagem não é o único mediador da cultura. Em muitas partes da África Ocidental e central, povos de diversos grupos linguísticos interagiam no dia-a-dia, em virtude da proximidade física ou das relações comerciais. Ao longo dessas interações, eles podiam trocar noções culturais, mesmo sem uma linguagem comum. Desta forma, podiam compartilhar idéias religiosas ou princípios estéticos, pois possuíam uma religião comum ou uma herança artística, a despeito da diversidade linguística ${ }^{381 .}$
\end{abstract}

Levando-se em consideração que os escravizados que aportaram no Vale do Ribeira eram provenientes, majoritariamente, da África Centro-Ocidental, e apoiando-nos em Thornton, podemos classificá-los como oriundos de uma grande

entre os rios Zaire, Cuango e Cuvo". (PARREIRA, 1997, p. 196).

377 MINTZ, Sidney; PRICE, Richard. O nascimento da cultura afro-americana: Uma perspectiva antropológica. Trad: Vera Ribeiro. Rio de Janeiro: Pallas - UCAM, 2003, p. 37.

${ }^{378}$ MINTZ, Sidney; PRICE, Richard, op. cit., p. 27-33.

${ }^{379}$ THORNTON, 2000, p. 253-254.

${ }^{380}$ THORNTON, op. cit., p. 256-263.

${ }^{381}$ Ibid., p. 256-257. 
zona cultural - a região de Angola. Ali, a grande maioria das pessoas falava kikongo ou kimbundo. Essas duas línguas "[...] eram tão similares como o espanhol e o português, de acordo com Duarte Lopes ao final do século XVI" ${ }^{382}$. Não só a língua, essas populações compartilhavam também ideias religiosas, princípios estéticos e conceitos filosóficos.

Robert Slenes destacou que os escravizados procedentes da África CentroOcidental eram de origem banto e define esse termo como o nome genérico de um grande grupo linguístico, composto por línguas faladas por diferentes povos, aldeias, confederações e reinos da África Centro-Ocidental. A afinidade que unia esses povos extrapolava a língua, pois também compartilhavam pressupostos culturais básicos ${ }^{383}$.

No caso do Vale do Ribeira, parece que existiu uma "herança generalizada" compartilhada pelos povos da África Centro-Ocidental que aportaram na região - a crença nos "espíritos das águas". Os negros d'água da região do Rio Ribeira assemelham-se aos "espíritos das águas" dos contos angolanos descritos por Henri Chatelain, os quais também podiam ser chamados de Kianda, Kiximbi, Lucala, Cuanza e Kituta. Também são similares aos "espíritos das águas" descritos por Slenes, denominados Simbi, Kiximbi ou Kinda.

Conforme Slenes, o culto aos "espíritos das águas" assegurava a fertilidade da agricultura e das mulheres, a saúde e o bem-estar da comunidade. O mesmo pesquisador, baseando-se nos escritos do missionário Karl Laman ${ }^{384}$ sobre os basundi, destacou que os bissimbi, geralmente, eram benevolentes com as pessoas da região, embora eles castigassem quem não se comportava bem. Eles puniam não apenas aqueles que os insultavam (por exemplo, aqueles que abusavam de sua generosidade e só queriam comer peixe), mas também aqueles que prejudicavam as pessoas. Por exemplo, se um ladrão atravessasse o rio sem confessar a sua culpa, os bissimbi viravam sua canoa ${ }^{385}$, tal qual os negros d'água do Rio Ribeira.

Há outros pontos em comum entre os negros d'água do Rio Ribeira e os

\footnotetext{
${ }^{382}$ Ibid., p. 262.

383 SLENES, Robert W. Malungo, Ngoma vem: África coberta e descoberta no Brasil. Revista USP, São Paulo, n. 12, 1991/92, p. 215.

${ }^{384}$ Karl Laman foi um missionário suíço que atuou no Congo entre os anos de 1891 e 1919.

385 SLENES, R. The Great Porpoise-Skull. In: HEYWOOD, Linda M. (Ed). Central Africans and Cultural Transformations in the American Diaspora. Cambridge: Cambridge University Press, 2002, p. 194. 
"espíritos das águas" centro-africanos. Em muitos relatos, assim como os negros d'água, os "espíritos das águas" também apresentavam baixa estatura. Ressaltamos que a baixa-estatura dos negros d'água do rio São Francisco e do rio Cuiabá também foi destacada nos relatos coletados.

Outro ponto em comum entre negros d'água e "espíritos das águas" é o local de moradia. Os negros d'água moravam em grutas de pedra existentes no fundo dos rios, mas também eram vistos em revessas, correntezas e poços profundos. Quanto aos "espíritos das águas", MacGaffey destacou que eles habitavam pedras, poços, lagos e correntezas ${ }^{386}$. Slenes, baseando-se em Tuckey, assinalou que as pedras eram a peculiar residência dos seembi e, apoiando-se em Laman, frisou que eles moravam em grutas de pedra existentes no fundo das águas ${ }^{387}$.

Há, ainda, outro ponto em comum: o sequestro de mulheres. Os negros d'água da região do Rio Ribeira sequestravam mulheres da terra, assim como a Kianda levou uma mulher para viver com ele no fundo do rio ${ }^{388}$.

Os negros d'água do Rio Ribeira também podem estar relacionados com outro pressuposto amplamente compartilhado por centro-africanos, o "complexo ventura-desventura". Conforme Marina de Mello e Souza, baseando-se em Fox, Craemer e Vansina:

Segundo esse paradigma, a ordem natural das coisas seria boa e desejável, envolvendo valores positivos como a saúde, a fecundidade, a segurança e a harmonia. O criador, ser supremo, que deu vida a tudo, reinaria distante, mas benevolente sobre o universo e os homens. O espaço entre os vivos e os mortos estaria ocupado pelos ancestrais e por vários tipos de espíritos, portadores de boas intenções. Assim, se a vida fluísse no seu curso natural, tudo transcorreria dentro da ventura, mas isso raramente acontecia, uma vez que forças maléficas desviavam-na de seu caminho. Todo o mal seria provocado por essas forças a partir de atos conscientes ou inadvertidos de determinadas pessoas ${ }^{389}$.

Relacionado ao "complexo ventura-desventura" temos outro principio básico centro-africano, "[...] a religious cosmology based on the division between the world of the living and the world of the spirits, with a particular emphasis on the importance

${ }^{386}$ MACGAFFEY, Wyatt. Twins, Simbi Spirits, and Lwas in Kongo and Haiti. In: HEYWOOD, op. cit., p. 212.

${ }^{387}$ SLENES, op. cit., p. 201.

${ }^{388}$ CHATELAIN, 1964, p.249.

${ }^{389}$ SOUZA, Marina de Mello. Reis Negros no Brasil escravista: História da Festa da Coroação de Rei Congo. Belo Horizonte: Ed. UFMG, 2002, p. 70. 
of ancestral spirits" ${ }^{390}$. O mundo dos espíritos podia interferir no mundo dos vivos, causando ventura ou desventura. Os espíritos ancestrais esperavam ser homenageados pelos seus parentes vivos, pois eram as oferendas que garantiam sua potência no além. Em retribuição, protegeriam seus descendentes do mal, intervindo no dia a dia da comunidade. Por exemplo, ajudariam os caçadores na floresta e as mulheres no momento do parto. Esses dois mundos "[...] were separated by a large body of water through which the dead had to pass in order to reach the other world"391.

Thompson ressaltou que o mundo, na cultura "kongo"392, é apreendido segundo o "cosmograma kongo". Graficamente, pode ser representado por uma cruz $(+)$, cuja barra horizontal simboliza a kalunga (as águas do rio ou do mar, ou qualquer superfície reflexiva como, por exemplo, um espelho), a qual divide dois mundos especulares: o mundo dos vivos (metade superior) e o mundo dos mortos (metade inferior). A barra vertical liga o mundo visível, dos vivos, ao mundo invisível, dos mortos e dos espíritos. As quatro pontas da cruz representam os quatro momentos do sol. O ponto localizado na extremidade horizontal, à direita (Leste), representa o nascer do dia, quando o sol rompe a barreira da kalunga e começa o seu percurso no mundo dos vivos. O ponto mais alto da cruz, na extremidade vertical (Norte), significa o meio-dia e o apogeu da força de uma pessoa do reino dos vivos. O ponto localizado na extremidade horizontal, à esquerda (Oeste), simboliza o fim da vida visível de uma pessoa e o pôr do sol, momento em que o sol rompe novamente a kalunga e começa a percorrer o mundo dos mortos. O ponto mais baixo da cruz, na extremidade vertical (Sul), representa a meia-noite e o apogeu da força de um ser do outro mundo. O sol, ao percorrer os quatro pontos do cosmograma, atravessa os reinos dos vivos e dos mortos, existindo um eterno retorno noite/dia e vida/morte ${ }^{393}$.

\footnotetext{
390 SWEET, James. Recreating Africa. Culture, Kinship, and Religion in the African-Portuguese World, 1441-1770. North Carolina: The University of North Carolina Press, 2003, p. 103.

${ }^{391}$ SWEET, op. cit., p. 104.

392 Considerando que grande parte dos africanos oriundos da África Centro-Ocidental possuía uma cultura "menos heterogênea e menos particularista do que geralmente se supõe" (SLENES, 1991, p. 216), que foram socializados na cultura "kongo" ou em culturas relacionadas (SLENES, 1991, p. 215) e que "Kongos" e "Angolas" que vieram para a América compartilhavam muitas crenças e línguas (THOMPSON, 1983, p. 104), ao abordarmos a cultura "kongo", estaremos tratando-a como paradigmática para uma extensa região da África Centro-Ocidental.

${ }_{393}$ THOMPSON, Robert Farris. Flash of the Spirit: African and afro-american art and philosophy. New York: Vintage Books, 1984, p. 108. 
O mito dos negros d'água do Rio Ribeira parece ecoar o pressuposto básico da existência desses dois mundos. Além dos negros d'água, o Rio Ribeira também conta com a presença de outros seres, como o boi d'água, o cachorro d'água e o cavalo d'água. A existência desses seres é explicada da seguinte forma pelos atuais moradores da região: "Tudo que tem na terra, tem na água". Novamente, a crença na existência de dois mundos especulares (de vivos e mortos) parece alicerçar essa afirmação.

Negros d'água, como Inácio Marinho e Gregório Marinho, eram seres que atravessavam águas e circulavam por mundos distintos. Era possível atravessar as águas de baixo para cima (significando "renascer") e de cima para baixo (significando "morrer") ${ }^{394}$. Originários do fundo das águas, os negros d'água pertenciam, portanto, ao mundo debaixo, ao mundo dos mortos. Como geraram descendência, não eram apenas mortos, eram ancestrais. Desse modo, os negros d'água representavam espíritos ancestrais, oriundos do reino dos mortos que, ao cruzarem as águas, propiciaram vida, ou seja, originaram descendência. Portanto, o mito do negro d'água alude ao movimento contínuo da vida e da morte, ao eterno retorno dia/noite. Assim, podemos inscrever esse mito dentro de um conjunto de referências culturais centrado no conceito de kalunga.

${ }^{394}$ SLENES, 1992, p. 53-54. 


\subsection{O Cuanza, o Ribeira e o Atlântico}

O mito do negro d'água narra a travessia das águas doces do Rio Ribeira. No entanto, simbolicamente, poderia também representar as águas salgadas atravessadas por muitos africanos que aportaram no Vale do Ribeira. O sobrenome dos negros d'água - Marinho - reforça a hipótese do sentido do mito prender-se às águas do mar. Simbolicamente e concretamente, uma quantidade enorme de africanos atravessou "a grande água", a kalunga, o oceano. E essa experiência deixou marcas profundas, as quais, possivelmente, influenciaram a criação dos mitos.

Principalmente na longa travessia do Atlântico, mas também antes disso, ainda na África, nos comboios e nas feitorias, formaram-se os primeiros laços sociais. Homogeneizados por um sistema desumanizante, homens e mulheres desenvolveram esforços de cooperação, os quais podem ser vistos como os primórdios das culturas afro-americanas ${ }^{395}$. Novos vínculos sociais foram estabelecidos, assim como novos sistemas culturais começaram a tomar forma ${ }^{396}$. Um forte vínculo unia malungos, ou seja, "companheiros de embarcação", companheiros de desventura, num processo de metonímia que transformou "meu barco/navio" em "meu companheiro de embarcação"397.

Escravizados vindos do interior, falantes de línguas banto diferentes de kikongo, kibundu e umbundu, teriam compreendido malungo como "companheiros" não através do conceito de "barco", mas pelo conceito de "irmão/parente". Coincidentemente, existem três vocábulos-raízes do proto-bantu "[...] que assumem formas em línguas modernas às vezes não muito distantes de 'malungo', e que têm uma difusão bastante grande no Centro e no Leste da África bantu" ${ }^{398}$.

Desvendando significados cosmológicos, Slenes levantou a hipótese de malungo também estar associado com um vocábulo-raiz do proto-bantu muito difundido na África Central e Austral - com o vocábulo donga, o qual significa rio,

\footnotetext{
${ }^{395}$ MINTZ, Sidney; PRICE, Richard, op. cit., p. 65. MINTZ, Sidney; PRICE, Richard. O nascimento da cultura afro-americana: uma perspectiva antropológica. Tradução de Vera Ribeiro. Rio de Janeiro: Pallas / UCAM, 2003.

${ }^{396}$ Ibid., p. 68.

${ }^{397}$ SLENES, 1992, p. 53.

${ }^{398}$ SLENES, 1992, p. 53 
vale ou canal. Esse vocábulo em kikongo, kimbundu e umbundu toma a forma de kalunga, adquirindo também o significado de "mar". Conforme Slenes:

É possível que nlungu (em kikongo) e ulungu (em kibundu) sejam derivados da mesma raiz que kalunga, também por metonímia (isto é, que de "rio/mar" tenha-se chegado a "canoa"). Seja como for, para escravos falantes desses três idiomas, ou para povos que compartilhavam sua cultura, "malungo" não teria significado apenas "meu barco", e por extensão "camarada da mesma embarcação", mas forçosamente também "companheiro da travessia da kalunga" ${ }^{399}$.

Atravessar a kalunga significava "morrer" ou "renascer". Assim, malungos eram "companheiros da travessia da vida para a morte" ou "companheiros da travessia da morte para a vida" ${ }^{400}$. Muitos povos da região Congo-Angola relacionavam a cor branca com a morte. Assim, os homens eram pretos, e os espíritos, brancos. Os mortos iam para Mputu - a terra dos brancos, a terra dos mortos. Associaram Portugal a Mputu. Dessa forma, simbolicamente, atravessar a kalunga em direção à terra dos brancos significava "morrer"401. E, de fato, ao atravessar o Atlântico em tumbeiros, milhares de africanos pereceram ${ }^{402}$.

Atravessar o Atlântico em direção à América significou ruptura e morte. Mas, como mencionado anteriormente, conforme o "cosmograma kongo", o movimento do sol ao redor da kalunga é circular, ou seja, há um eterno retorno dia/noite, vida/morte. Atravessar a kalunga também significou renascimento. O negro d'água do Rio Ribeira atravessou as águas da kalunga de baixo para cima, ou seja, do reino dos mortos para o reino dos vivos. O mito, assim, também enfatiza o renascimento e o reino dos vivos. Isso fica mais claro pelo fato de os negros d'água gerarem descendência, ou seja, vida.

O mito aborda o movimento contínuo da vida e da morte. Na travessia da kalunga, algo morre e algo renasce. O que renasce tem relação com o que morreu.

\footnotetext{
${ }^{399}$ Ibid., p. 53.

${ }^{400}$ bid., p. 54.

401 lbid., p. 54.

${ }^{402}$ A palavra "malungo" devia ser utilizada pelos negros da região pesquisada no passado. Ainda hoje é utilizada, mas com um sentido diferente. Em 2011, uma senhora de 74 anos da Comunidade Remanescente de Quilombo de Nhunguara relatou que quando era criança participava da "Recomendação das Almas", ou seja, de uma cerimônia em louvor aos mortos, "com o pessoal malongo". Ela definiu "malongo" como pessoas que tinham a mesma idade. (ANDRADE, Anna Maria; TATTO, Nilto. Inventário Cultural de Quilombos do Vale do Ribeira. São Paulo: Instituto Sociambiental, 2013, p. 70). 
Dessa forma, o mito do negro d'água narra o nascimento de um novo mundo a partir da transformação de elementos de um mundo antigo. De acordo com Mintz e Price, com a travessia atlântica e a consequente destruição dos antigos laços sociais, "[...] a 'bagagem cultural' de cada indivíduo sofre uma transformação fenomenológica, até que a criação de novas estruturas institucionais permita a refabricação do conteúdo, baseado no passado - e muito distante dele"403. Desse modo, na criação do mito dos negros d'água foram utilizados conteúdos culturais pré-existentes - como a crença nos "espíritos d'água" e na kalunga que divide os reinos dos vivos e dos mortos-, os quais foram transformados em algo novo.

De forma análoga, na América também surgiu um mundo novo, marcado pela travessia atlântica e caracterizado pelo escravismo. Assim, novas formas sociais e culturais foram forjadas para enfrentar as necessidades cotidianas de uma sociedade escravista ${ }^{404}$. Uma explicação para o trauma da travessia atlântica e da escravidão foi uma dessas necessidades. Como enfatizaram Mintz e Price, "[...] qualquer aglomerado de escravos da plantation teria primeiro que lidar com os traumas da captura, da escravidão e do transporte" ${ }^{405}$. O mito do negro d'água serviu a esse propósito, pois conferiu sentido à nova realidade vivida ao abordar questões referentes à travessia marítima e ao mundo da escravidão.

O mito retrata a violência do mundo da escravidão. O ponto inicial era o aprisionamento. Geralmente, os negros d'água eram capturados com anzóis e tarrafas. Assim, involuntariamente e com violência, os negros d'água foram arrancados do seu mundo e lançados numa nova realidade. Semelhantemente, os africanos foram tirados de sua terra natal e inseridos num outro espaço. A passagem de um mundo para o outro - do fundo das águas para a terra, no caso dos negros d'água; e da África para a América, no caso dos africanos - foi realizada através da transposição das águas.

A violência da escravidão também pode ser evidenciada pelo fato de os negros d'água, durante a escravidão, terem os "[...] as mãos e os pés cortados com navalhas, uma vez que eram como os de patos" ${ }^{406}$. Dessa forma, o mito parece fazer

\footnotetext{
${ }^{403}$ MINTZ; PRICE, 2003, p. 71.

${ }^{404}$ Ibid., p. 112-114.

${ }^{405}$ Ibid., p. 65.

${ }^{406}$ MIRALES, Rosana. A identidade quilombola das comunidades Pedro Cubas e Ivaporunduva. 1998. 109
} 
menção à violência física e à perda da mobilidade e, simbolicamente, da liberdade ${ }^{407}$. A questão da aprendizagem de uma nova língua também chama atenção - tanto negros d'água como africanos tiveram que aprender a língua do local onde passaram a morar.

No mundo da escravidão, existiram relacionamentos entre homens e mulheres de diferentes etnias, origens e posições sociais. No mito do negro d'água, esses relacionamentos também estavam presentes. Os negros d'água citados, Inácio e Gregório Marinho, casaram-se com mulheres da terra e geraram filhos. As mulheres da terra também podiam ser sequestradas pelos negros d'água. Tornar-seiam suas esposas e viveriam no fundo das águas. Esses relacionamentos entre pessoas da terra e da água ocupavam um papel destacado no mito, apontando para o fato de que esses relacionamentos foram muito frequentes no mundo da escravidão. Diferentemente das mulheres, homens e crianças podiam ter outro fim. No mito, havia o receio dos homens serem mortos e as crianças devoradas. Medo da morte e medo do devoramento ${ }^{408}$ eram temores que se assemelhavam aos que os africanos sentiam frente à possibilidade de serem escravizados e obrigados a realizar a travessia atlântica.

No mito do negro d'água, um elemento se sobressai: o sal. Os negros d'água eram amansados com sal, ou seja, após a sua ingestão, seu temperamento bravio era domado e ajustado às regras do local para onde foram levados. Entre os centroafricanos, existiam certas crenças associadas ao sal. Monica Schuler, ao pesquisar africanos de origem congolesa que, entre os anos de 1841 e 1865, foram levados para a Jamaica, notou que eles acreditavam que, assim como os espíritos não ingeriam sal, a abstenção desse elemento conferia-lhes poderes semelhantes, tais como o poder de interpretar o mundo ao seu redor e voar de volta para a África. Ou

Dissertação (Mestrado em Ciências Sociais) - Pontifícia Universidade Católica, São Paulo, 1998, p. 73.

${ }^{407}$ Cascudo observou que amuletos feitos com patas de coelho eram muito populares no Mercado de São José (Recife) e no Mercado Público de Salvador. Segundo o pesquisador, "[...] o pé representa a estabilidade, a posse, a segurança, a firmeza, o equilíbrio. Também está ligado à imagem da locomoção, agilidade, movimento, defesa na fuga ou nas reações imediatas". Ele destacou que em "várias orações antigas suplicava-se a imposição do pé de um Santo como uma intervenção benéfica" e citou uma oração coletada por Hermann Urtel em Portugal, em 1928: "Senhora da Conceição, Ponde aqui a vossa mão; Senhor /São José, Ponde aqui o vosso pé!”. (CASCUDO, Luis da Câmara. Made in África. Rio de Janeiro: Editora Civilização Brasileira S.A, 1965).

${ }^{408}$ Conforme Sweet, "[...] it was widely understood that Europeans carried away black bodies in order to 'eat' them". (SWEET, 2003, p. 162). 
seja, a ausência de sal garantia a integridade espiritual ${ }^{409}$. De forma análoga, o sal dado ao negro d'água fazia com que ele perdesse suas características originais e, assim, se ajustasse a uma nova situação.

Sal e água. Esses são os elementos fundamentais do batismo. Tanto no Brasil quanto na África existiu um esforço para a conversão dos africanos ao catolicismo e o batismo era o rito de iniciação. Dessa forma, esse sacramento ocupou papel central na vida religiosa das sociedades formadas nos dois lados do Atlântico. Alguns autores frisaram essa associação entre o sal e o catolicismo, feita pelos centro-africanos. Cavazzi destacou que os africanos chamavam o batismo de "Santo Sal" ${ }^{410}$. Sweet também ressaltou que eles associavam a prática ritual ao ato de "comer sal" ${ }^{411}$. Cascudo fez a seguinte observação sobre os negros de Angola que viviam no Brasil:

Os negros de Angola não encontraram melhor símbolo (o sal) para o batizado. Se são cristãos, informam: Didimungua, comi sal. O padrinho é o pai de sal, tat'a mungua. A madrinha, mãe do sal, mam'a munga. O afilhado, filho do sal, mon'a munga. Os companheiros de batizado, irmãos do sal, pange a mungua ${ }^{412}$.

No mito do negro dágua, o sal parece ser uma clara alusão ao batismo. Após ingerir sal, o negro dágua amansou, ou seja, seu espírito foi modificado e ele passou a ter um comportamento adequado às novas regras. Portanto, o mito do negro d'água parece retratar a inserção do africano a um novo mundo, o qual era caracterizado, fundamentalmente, pelo catolicismo. Essa associação entre os negros d'água e mundo cristão torna-se ainda mais evidente na história do negro d'água de Ivaporunduva (Inácio Marinho), o qual fora capturado durante a comemoração da Festa de Santa Cruz e batizado por um vigário.

Segundo Rosana Mirales, a ingestão de sal provocava a expulsão da pedra alojada no estômago do negro d'água. As pedras eram os locais de moradia do negro d'água, portanto, poderiam ser relacionadas com mundo original, no caso, com a África. Simbolicamente, talvez a pedra representasse as tradições e crenças

\footnotetext{
${ }^{409}$ SLENES, 1992, p. 54.

${ }^{410}$ MONTECÚCCOLO, 1965, p. 130.

${ }^{411}$ SWEET, 2003, p. 56.

${ }^{412}$ CASCUDO, 1998, p. 796. 
africanas. A oposição catolicismo versus crenças africanas talvez fosse representada pela oposição sal versus pedra. O mito parece abordar não apenas a conversão do africano ao catolicismo, mas também os esforços realizados para a "eliminação" das religiosidades tradicionais africanas.

Sal e água. São esses os elementos que compunham a travessia atlântica. Assim como o batismo, cruzar as águas salgadas do Atlântico também representava um rito de passagem. A travessia do Atlântico conduzia a um mundo novo. Realizada por africanos e europeus, desse rito de passagem emergiu a sociedade colonial brasileira.

Possivelmente, o enraizamento, a longevidade e a força do mito do negro d'água advêm da sua capacidade de servir de metáfora da travessia marítima, da escravidão e da formação de um mundo novo. Metáfora capaz de traduzir a realidade da morte e da vida de muitos africanos que cruzaram a kalunga. Metáfora da nossa situação colonial. Metáfora da formação de um mundo novo, o qual foi construído pelos indígenas que aqui estavam, juntamente com os africanos e europeus que cruzaram as águas do Atlântico. E, "[...] de um Novo Mundo se trata, por certo, pois aqueles que se tornaram seus povos o refizeram e, nesses processos, refizeram a si mesmos". 413

${ }^{413}$ MINTZ; PRICE, 2003, p. 113. 


\subsection{O Atlântico}

Muitos autores descreveram as desventuras sofridas na travessia atlântica. O missionário Cavazzi sublinhou que "[...] aborrecedoras calmarias, tempestades, perigos de recifes, de afundamento, de encalhe nos bancos de areia, de encontro com corsários, convulsões estomacais, vertigens: tudo isto são acontecimentos ordinários para os navegantes" ${ }^{414}$. Além disso, Cavazzi também destacou a fome, a sede e os naufrágios.

Muitos missionários faleceram durante a travessia. Foi o caso do Padre Salvador de Génova, que adoeceu, morreu e seu "cadáver teve a costumada sepultura no oceano" ${ }^{\text {"15. }}$. O mesmo fim teve o Padre Clemente de Maenza. Quando ele estava voltando para a Europa, no quinto dia de viagem, foi acometido por uma doença contagiosa. Nesses casos, as pessoas eram lançadas ao mar. No entanto, o capitão não quis fazer isso com um sacerdote. O Pe. Clemente foi isolado e the entregavam comida por meio de um pau comprido. Por fim, morreu e o "cadáver do Pe. Clemente teve sepultura no oceano" ${ }^{416}$.

Quanto aos homens que trabalhavam no mar - em navios mercantes e de guerra -, Jaime Rodrigues afirmou que os estudos que se preocuparam em caracterizar a vida nas embarcações "[...] revelaram um cotidiano profundamente marcado pelo sofrimento - constatação válida para diferentes temporalidades históricas e cronológicas" ${ }^{417}$. Os marinheiros eram mal remunerados, explorados pelos oficiais e lutavam para sobreviver por meio de mantimentos e água muitas vezes estragados. Os desgastes físicos e mentais a que eram submetidos minavam suas vidas ${ }^{418}$.

Se o sofrimento dos capuchinhos e dos marinheiros era grande, o dos escravizados alojados nos tumbeiros era ainda maior ${ }^{419}$. Muitas pessoas, como o

\footnotetext{
${ }^{414}$ MONTECÚCCOLO, 1965, livro terceiro, p. 299.

${ }^{415}$ Ibid., livro terceiro, p. 308.

${ }^{416}$ Ibid., p. 178.

${ }^{417}$ RODRIGUES, Jaime. De costa a costa: escravos, marinhos e intermediários do tráfico negreiro de Angola ao Rio de Janeiro (1780 - 1860). São Paulo: Companhia das Letras, p. 205.

${ }^{418}$ Ibid., p. 185.

${ }^{419} \mathrm{De}$ acordo com Sweet: "Tornar-se escravo no interior da África significava entrar num mundo de 113
} 
pintor Rugendas, descreveram o que acontecia nos porões dos navios ${ }^{420}$. Entre muitos episódios ocorridos no mar, Cavazzi citou a viagem de Luanda para o Brasil realizada pelo Pe. Boaventura de Sorrento em 1649. Novecentos escravizados estavam na embarcação. De acordo com Cavazzi: "[...] as angustiosas condições do barco e a desordem com que tanta multidão estava amontoada confusamente, sem distinção de idades nem de sexos, causaram muitos incovenientes, entre os quais uma doença que matou 250 daqueles infelizes". A embarcação, "[...] pelo intolerável fedor, pela escassez de espaço, pelos gritos contínuos e pelas infinitas misérias de tantos infelizes, parecia um inferno" ${ }^{421}$.

Para muitos centro-africanos, a morte era preferível à travessia atlântica muitos deles, condenados a viver na América, tentavam se matar. Assim, conforme Cavazzi, "[...] quase todos os pretos, ao ouvirem esta condenação, preferem morrer, de maneira que os seus patrãos deviam vigiar muito bem para que eles se não matem mutuamente"422. O terror era causado porque julgavam que seriam devorados na América $^{423}$. Eles acreditavam que seus ossos seriam utilizados na fabricação de pólvora e que seus miolos e carnes serviriam para a produção de azeite. No momento do embarque, ou mesmo em alto-mar, muito centro-africanos se lançavam nas águas ${ }^{424}$.

Quanto aos escravizados da África Ocidental, Jaime Rodrigues, baseando-se nas pesquisas de Winston McGowan, afirmou que a principal razão para a resistência dos escravizados era a crença de que um terrível destino os esperava na travessia atlântica. Eles acreditavam que serviriam como oferendas humanas às divindades europeias, seu sangue seria usado como corante ou que seriam

doença, fome e morte. Se a marcha até à costa africana, o encarceramento nos barracões costeiros ou a travessia atlântica não tirassem a vida, as doenças acabariam por fazê-lo. Para um escravo nascido em África, era de facto um feito extraordinário chegar ao Brasil e viver mais de três anos. No final do século XVIII, durante esta janela temporal de três anos conhecida como o período de 'adaptação', mais de $40 \%$ dos africanos que sobreviviam à travessia atlântica sucumbiam às muitas doenças do continente americano". SWEET, James H. Recriar África: cultura, parentesco e religião no mundo afro-português (1441-1770). Tradução João Reis Nunes. Lisboa: Edições 70, 2007, p. 83.

${ }_{420}$ RODRIGUES, Jaime. De costa a costa: escravos, marinhos e intermediários do tráfico negreiro de Angola ao Rio de Janeiro (1780 - 1860). São Paulo: Companhia das Letras, p. 132.

${ }^{421}$ MONTECÚCCOLO, 1965, livro quarto, p. 379.

${ }^{422}$ Ibid., livro sétimo, p. 171.

${ }^{423}$ Ibid., livro sexto, p. 146.

${ }^{424}$ Ibid., livro segundo, p. 160. 
devorados por canibais brancos ${ }^{425}$.

O medo do destino na América motivou suicídios e revoltas. Conforme Cavazzi: "Certa vez, quando o navio se achava no alto mar, os escravos embarcados assaltaram os brancos, matando-os a todos, excepto o piloto, que obrigaram a voltar para as suas terras." ${ }^{426}$

Os comerciantes de escravizados fizeram adaptações nas embarcações para a prevenção de revoltas e suicídios, como a colocação de grades nas escotilhas ${ }^{427}$. Quanto às revoltas em alto-mar, conforme Jaime Rodrigues:

\begin{abstract}
Muito embora os africanos aprisionados se rebelassem em diversas fases da escravização - na captura em seus territórios de origem, na viagem até a costa ou durante a permanência nos barracões - era nos navios negreiros que as revoltas provocavam maior temor aos brancos. Para os escravos, essa modalidade de resistência poderia ser a última antes de se verem enredados em uma viagem sem retorno. Para os marinheiros, enfrentar uma revolta de escravos a bordo era um dos medos mais constantes, já que estariam lidando com inimigos pouco dispostos a negociar numa luta que não se encerrava enquanto restasse um tripulante vivo nas mãos dos rebelados $^{428}$.
\end{abstract}

Jaime Rodrigues sublinhou que as poucas evidências sobre as rebeliões escravas a bordo apontam para fracassos. No entanto, destacou que, entre as muitas causas para o desaparecimento dos navios, como naufrágios causados por tempestades e imperícias, "[...] as perdas também podem ter sido provocadas por revoltas de escravos, que, embora bem-sucedidas, não conseguiram fazer o navio chegar a porto algum"429.

Martin Lienhard, ao pesquisar mambos (cantigas rituais) cubanos, observou fragmentos que abordavam a travessia marítima:

[...] o mar aparece como elo que liga, na visão dos descendentes de escravos, a América à África: um vínculo ao mesmo tempo espacial, histórico e religioso. Em termos espaciais, o mar é o elemento que liga e separa os dois continentes vizinhos. Historicamente, o mar foi o caminho que tiveram de percorrer os africanos ao serem deportados para a América. No fundo do mar estão, ademais, os espíritos dos escravos que morreram

\footnotetext{
${ }^{425}$ RODRIGUES, De costa a costa: escravos, marinhos e intermediários do tráfico negreiro de Angola ao Rio de Janeiro (1780 - 1860), p. 226 e 243.

${ }^{426}$ MONTECÚCCOLO, 1965, livro segundo, p. 160.

${ }^{427}$ RODRIGUES, op. cit., p. 247

428 Ibid., p. 244.

429 Ibid., p. 246.

115
} 
na travessia ou que se afogaram num naufrágio. O mar é, logo, parte essencial da história da escravidão $0^{430}$

Seja pelos temores, pelos maus-tratos, pela fome, pela sede, pelas doenças, provavelmente, a melhor metáfora do sofrimento da travessia do Atlântico/Kalunga tenha sido feita por Fernando Pessoa, para quem as águas e o sal do mar resultavam do derramamento de lágrimas ${ }^{431}$.

\subsection{O Atlântico e as Águas Cristãs}

A água, o sal, o mar e as lágrimas foram, do mesmo modo, muito citados nos sermões do Padre Antônio Vieira (1608-1697), e destacaremos alguns trechos da obra desse religioso pela sua importância política e intelectual. Num dos seus sermões, ele afirmou que o continente americano estava submerso antes da chegada dos portugueses. Conforme Vieira:

Quando Deus criou o mundo, diz o sagrado Texto, que a terra não se via porque estava escondida debaixo do elemento água, e toda escura e coberta de trevas. Então dividiu Deus as águas, e apareceu a terra: criou a luz e cessaram as trevas. Este foi o modo da primeira criação do mundo. E quem não vê que o mesmo observou Deus na segunda por meio dos portugueses? Estava todo o Novo Mundo em trevas e às escuras, porque não era conhecido. Tudo o que ali havia, sendo tanto, era como se não fosse nada, porque assim se cuidava e tinha por fábula. O que encobria a terra era o elemento água; porque a imensidade do Oceano, que estava em meio, se julgava insuperável, como a julgavam todos os antigos, e entre eles Santo Agostinho. Atreveu-se, finalmente, a ousadia e zelo dos portugueses a desfazer este encanto, e vencer este impossível. Começaram a dividir as águas nunca dantes cortadas, com as aventurosas proas dos seus primeiros lenhos: foram aparecendo e surgindo uma e outra parte, e como nascendo de novo as terras, as gentes, o mundo que as mesmas águas encobriam; e não só acabaram então no mundo antigo as trevas desta ignorância, mas muito mais no Novo e descoberto, as trevas da infidelidade, porque amanheceu nelas a luz do Evangelho e o conhecimento

${ }^{430}$ LIENHARD. Martin. O Mar e o Mato: Histórias da Escravidão (Congo-Angola, Brasil, Caribe). Salvador : EDUFBA/CEAO, 1998, p. 46.

${ }^{431}$ PESSOA, Fernando. Mar Português. In: Mensagem. Edições Ática: Lisboa. 1959, p. 45. 
de Cristo, o qual era o que guiava os portugueses e com eles navegava ${ }^{432}$.

Portugal e Espanha desejavam tornar o Atlântico um espaço reservado para a Cristandade. Sheila Maria Doula comparou esse anseio em relação ao Atlântico ao que existia anteriormente em relação ao Mediterrâneo - almejado como um mare nostrum cristão ${ }^{433}$. A pesquisadora sublinhou que a chegada do europeu à América impôs a necessidade de discutir a questão da pertença das fronteiras marítimas e, assim, surgiu o Tratado de Tordesilhas, que concedia a posse das águas e das terras de um mundo desconhecido a Portugal e Espanha. De acordo com Doula:

\begin{abstract}
O Tratado, documento referencial da concepção de um mare nostrum (de Espanha e Portugal), instaurou um descompasso e uma ruptura entre a Península Ibéria e os outros Estados, partidários então, pelo menos teoricamente, da concepção de um mare liberum em relação ao Grande Oceano. A Igreja, endossando e apoiando efetivamente os reinos ibéricos e por eles sendo apoiada - , também passou a conceber o mar como sendo nostrum, isto é, espaço para a evangelização e a expansão missionária do Cristianismo. ${ }^{434}$
\end{abstract}

A legitimidade do Tratado de Tordesilhas não foi reconhecida por algumas nações europeias, como Inglaterra, França e Holanda, que defendiam a concepção de um mare liberum. A Holanda foi a nação que mais diretamente afrontou os interesses de Portugal. A Holanda passava por um rápido processo de desenvolvimento mercantil e, assim, lançou-se ao mundo em nome dos seus interesses comerciais ${ }^{435}$.

As Companhias holandesas solicitaram ao jurista holandês Hugo Grotius a elaboração de um código sobre a liberdade dos mares. Em 1609, foi publicado o livro "Mare Liberum". Entre vários pontos, foi destacado que os portugueses não tinham direito de propriedade sobre as terras americanas a título de doação pontifícia e que o oceano, assim como o ar, não sendo apreensível, não podia ser

\footnotetext{
${ }^{432}$ VIEIRA, Antonio. Sermões escolhidos. São Paulo: Editora Martin Claret, 2004, p. 147-148.

${ }^{433}$ DOULA, Sheila Maria. Piratas: discursos e silêncios. 1997. Tese (Doutorado em Antropologia) Faculdade de Filosofia, Letras e Ciências Humanas da Universidade de São Paulo, São Paulo, 1997, p. 142.

434 Ibid., p. 43.

${ }^{435}$ Ibid., p. 94 - 102. 
acrescentado aos domínios de povo algum. Grotius sublinhou que o direito de propriedade pertencia a quem ocupava e trabalhava no território. O mar, cuja natureza impossibilitava qualquer tipo de benfeitoria e ocupação permanente, não podia ser propriedade de nenhuma nação. Além disso, o oceano não era um mar interior, era uma grande extensão de água que separava dois mundos ${ }^{436}$.

O Pe. Vieira, tenaz defensor dos interesses portugueses, utilizou nos seus sermões uma série de imagens que associavam as águas, o sal e o mar com o papel apostólico da Coroa portuguesa. Conforme Vieira: "Os Reis de Portugal são senhores do Mar Oceano, direito contra o qual se tem composto tantas Apologias, nas nações estrangeiras. E assim servir o elemento água aos nossos Reis não é maravilha, senão obrigação". Além de servir o elemento água, os reis portugueses também eram servidos pelo mesmo elemento. Na sequência, ele afirmou:

Assim serve o elemento da água aos Reis dados por Deus: assim serviu a Davi, assim serve, e assim há de servir ao nosso Rei nesta ocasião. Já nos serviu no mar, há-nos de servir no rio, há-nos de servir nas nuvens, há-nos de servir na terra; que ainda que o tempo promete chuvas e inundações, Deus é Senhor dos Céus e Criador das águas. ${ }^{437}$

Assim, Deus criou as águas e Portugal tinha obrigação de servir às águas criadas por Deus, logo, "servir as águas" simbolizava a obrigação de propagar a fé católica. E, se Portugal era servido pelas águas, ou seja, ocupava papel pioneiro em relação às grandes navegações, isso era por vontade divina, pois Jesus Cristo "guiava os portugueses e com eles navegava". Portanto, ao destacar o "elemento água", o Pe. Vieira frisou o papel missionário e a vanguarda marítima da Coroa portuguesa.

Para o Vieira, Portugal era o senhor do mar e Maria, a senhora. Ele lembrou que "Maria, quer dizer, Domina Maris: 'Senhora do mar"'438. Nos seus sermões, Maria estava tão associada às águas que, quando ela faleceu, "[...] faltou água ao Povo. Porque no mesmo ponto se secaram e sumiram as fontes, como se

\footnotetext{
${ }^{436}$ DOULA, 1997, p. $104-105$.

${ }^{437}$ VIEIRA, Antônio. Sermões. São Paulo: Hedra, 2001, p. 250-252.

${ }^{438}$ VIEIRA, 2004, p. 45. 
sepultassem com ela." ${ }^{439}$.

Pe. Vieira também ressaltava a aliança entre os portugueses e o papa, escolhidos por Deus - "Saiba o mundo, saibam os Hereges e os Gentios, que não se enganou Deus, quando fez aos Portugueses Conquistadores e Pregadores de seu Santo nome" - e que deveriam sujeitar todas as partes do mundo aos "pés do Sucessor de S. Pedro"440.

Pe. Vieira definiu Cristo como um grande pescador, imagem também relacionada a São Pedro e a todos os outros papas:

Cristo é grande pescador, porque do primeiro lanço pescou um pontífice; e Pedro grande pescador, porque sem recolher o lanço pescou o Pontificado. Isto é o que significam ainda hoje, e significarão até o fim do mundo as assinaturas e selos de todos os decretos Pontifícios, debaixo do anel do Pescador. ${ }^{441}$

Os apóstolos também foram vistos como pescadores. De acordo com $\mathrm{Pe}$. Vieira, Cristo afirmara "Sois Pescadores, Apóstolos meus, porque quero que vades pescar por esse mar do Mundo; mas advirto-vos que sois também sal; porque quero que pesqueis, não para comer, senão para conservar" ${ }^{442}$.

Os discípulos de Cristo deveriam percorrer o mundo e evangelizar, o que, na metáfora de pe. Vieira, traduzia-se em entranhar o sal na terra ${ }^{443}$. Conforme destacou, o sal tem dupla propriedade: tempera e é antídoto da corrupção. Dessa forma, a pregação, longe de ser insípida, deveria despertar amor à virtude e fidelidade à vontade divina. Os missionários, assim como os apóstolos, deveriam ser sal evangélico, ou seja, percorrer o mundo e exercitar o ofício do sal, o de ensinar os dogmas católicos, impedir a corrupção dos vícios e conservar as virtudes ${ }^{444}$. Pe. Vieria sublinhou o papel de Santo Antonio, que "foi sal da terra e foi sal do mar"445. Ele também frisou que o sal era formado pela junção de três elementos - o fogo, o ar

\footnotetext{
${ }^{439}$ VIEIRA, 2001, p. 484.

${ }^{440}$ Ibid., p. 320.

${ }^{441}$ lbid., p. 63.

${ }^{442}$ lbid., p. 320.

${ }^{443}$ Ibid., p. 331.

${ }^{444}$ MARQUES, João Francisco. Metáforas do sal na oratória sacra do seiscentismo português. In: I SEMINÁRIO INTERNACIONAL SOBRE O SAL PORTUGUÊS, 2005, Cidade do Porto. Anais do I Seminário sobre o sal português. Cidade do Porto: Instituto de História Moderna da Universidade do Porto, 2005, p. 349-363.

${ }^{445}$ VIEIRA, 2004, p. 45.
} 
e a água ${ }^{446}$.

Para Vieira, o sal "era filho do mar", assim como os peixes, os quais foram associados aos homens. Conforme Vieira, os homens/peixes deveriam se contentar com o seu elemento - a água. Com essa metáfora, defendia uma vida pautada pelos dogmas da Igreja e criticava a ambição do homem, vista como um pecado que o conduziria ao inferno. Vieira deu o seguinte conselho ao homem: "A natureza deu-te a água, tu não quiseste senão o ar, e eu já te vejo posto ao fogo. Peixes, contentese cada um com o seu elemento"447.

Vieira ressaltou que a água era "[...] sempre clara, diáfana e transparente, em que nada se pode ocultar, encobrir, nem dissimular" ${ }^{448}$. O batismo foi relacionado com a água, a qual era derramada para a remissão dos pecados" 449 .

O batismo era o "remédio do pecado original" ${ }^{450}$. Conforme a cosmologia cristã, Deus criou o mundo ao separar duas massas de água - a dos mares e a do céu. Adão e Eva viviam num jardim no paraíso terreal. No entanto, eles desobedeceram a Deus, o qual liberou as águas contidas no céu e provocou o dilúvio $^{451}$. Segundo Vieira, a transgressão de Adão transformou o mundo num "vale de lágrimas". Ele enfatizou: "[...] nasce o homem, diz Plínio, já chorando, e sem outra culpa mais que haver nascido, fica condenado a perpétuo pranto, começa a vida e o pranto juntamente; para que saiba, que se vem a este mundo, vem para chorar" ${ }^{252}$.

Assim, podemos perceber a importância das águas e do sal para a cosmologia cristã e para a missão catequética de Portugal.

\footnotetext{
${ }^{446}$ VIEIRA, 2001, p. 326.

${ }^{447}$ Ibid., p. 129.

${ }^{448}$ VIEIRA, 2004, p. 73.

${ }^{449}$ VIEIRA, 2001, p. 149.

${ }^{450}$ Ibid., p. 375.

${ }^{451}$ DOULA, 1997, p. $13-14$.

${ }^{452}$ VIEIRA, 2004, p. 199. 


\section{Capítulo 4 - Água e sal - Catolicismo na África Centro- Ocidental}

\subsection{O Trabalho Missionário}

A presença do catolicismo no Congo e em Angola data do século XVI. Em 1596, foi criada a diocese do Congo e Angola, subordinando o clero secular dessa região diretamente a Lisboa ${ }^{453}$.

No século XVI, missionários europeus da Companhia de Jesus foram enviados ao Congo para evangelizarem a população local. No século XVII, chegaram os capuchinhos. Nascida de um dos ramos franciscanos, a Ordem Capuchinha foi instituída pelo Frei Mateus de Bascio, o qual considerava que as normas de São Francisco estavam sendo seguidas muito frouxamente. Intencionando cumprir, literalmente, as regras de São Francisco de Assis, os capuchinhos:

[...] para garantir a austeridade e pobreza, tanto individual como coletiva, abdicavam de privilégios concedidos por diversos papas à ordem franciscana, incluindo ainda renúncia à remuneração dos trabalhos apostólicos e recurso à mendicância como meio de subsistência. No apostolado, a preferência ia para a pregação popular e para as missões entre "infiéis", portanto estavam dispostos a se dispersar pelo mundo a fim de propagar a fé católica. ${ }^{454}$

A ordem dos capuchinhos realizou a mais longa missão católica no Congo, a qual durou quase 200 anos, de 1645 a $1835^{455}$. O projeto de missionação dos capuchinhos estava relacionado com a Sagrada Congregação de Propaganda Fide. O papa Gregório XV, ao criar essa congregação em 1622, pretendia tomar as rédeas da propagação da fé cristã, colocando o projeto de evangelização acima dos interesses das monarquias europeias. Os religiosos enviados para missões mundo

\footnotetext{
${ }^{453}$ GONÇALVES, Rosana Andrea. Africa Indômita: missionários capuchinhos no reino do Congo (séc. XVII). 2008. Dissertação (Mestrado em História) - Faculdade de Ciências Humanas e Letras da Universidade de São Paulo, São Paulo, 2008, p. 38.

${ }^{454}$ Ibid., p. 57.

${ }^{455}$ Ibid., p. 39.

121
} 
afora respondiam diretamente ao Vaticano, rompendo-se, assim, o monopólio missionário das coroas portuguesas e espanholas ${ }^{456}$.

Administrativamente, a Sagrada Congregação de Propaganda Fide funcionava por meio de Prefeituras Apostólicas. Dessa forma, cada grupo de missionários formava uma prefeitura apostólica, liderada por um de seus membros, o prefeito, o qual respondia diretamente à Congregação. Em 1640, o papa Urbano VIII criou a Prefeitura Apostólica do Congo, composta por capuchinhos italianos. A presença de missionários estrangeiros na África Centro-Ocidental, muitos dos quais italianos e espanhóis, controlados pelo papa, desagradava a Coroa Portuguesa. Desejando manter sob seu jugo o trabalho catequético, a Coroa portuguesa, em muitas ocasiões, dificultou a circulação desses missionários não vinculados ao Padroado Português ${ }^{457}$.

Diferentemente do relacionamento tenso entre os portugueses e os capuchinhos, os jesuítas e a Coroa de Portugal estabeleceram uma relação de cooperação. A missão jesuíta sempre esteve vinculada ao projeto de exploração da Coroa portuguesa, a ponto de os jesuítas considerarem a sujeição do território denominado Angola a Portugal como um pré-requisito para o bom desempenho do trabalho evangelizador. Assim, em Luanda, o trabalho missionário dos jesuítas estava em andamento, concomitantemente ao processo político-administrativo em expansão. No Congo, mais especificamente em São Salvador, os jesuítas chegaram em 1548 e, em 1619, fundaram um colégio. Para auxiliar o trabalho de evangelização, os jesuítas interessaram-se em aprender línguas nativas, como o quimbundo e o quicongo. O profundo conhecimento que o jesuíta Mateus Cardoso possuía do quicongo possibilitou que, em 1624, publicasse um catecismo bilíngue português/kilongo ${ }^{458}$.

Além do trabalho espiritual, os jesuítas também se envolveram em questões do mundo material e, inclusive, participaram do comércio de escravizados. Foram importantes negociantes e até mesmo conseguiram angariar vultosa quantidade de bens. Diferentemente, os capuchinhos não atuaram no mundo dos negócios.

\footnotetext{
${ }^{456}$ GONÇALVES, 2008., p. 42 e 45.

${ }^{457}$ Ibid., p.43 - 66 .

${ }^{458}$ Ibid., p. $41-76$. 
Missionários mendicantes, eles orgulhavam-se do seu modo de vida marcado pela austeridade e pelo desprendimento material ${ }^{459}$. No entanto, isso não significou falta de intervenção no mundo temporal. Os capuchinhos, e essa também foi uma característica dos jesuítas, foram muito influentes politicamente e envolveram-se em vários conflitos.

O capuchinho italiano João Antonio Cavazzi de Montecuccolo viveu na África Central por treze anos (1654 - 1667). Baseando-se na sua experiência pessoal, no depoimento de outros missionários e em documentos encontrados em Luanda, Roma e em alguns conventos capuchinhos, o Pe. Cavazzi escreveu a história da missão capuchinha em Angola, Matamba e Congo, realizada entre os anos de 1645 e $1670^{460}$. Dessa forma, o relato de Cavazzi é muito importante, porque aborda o cotidiano do trabalho missionário, a relação entre africanos e europeus e lança luz à questão da apreensão do catolicismo pelos africanos. Gonçalves também defendeu a importância do relato de Cavazzi para o trabalho do historiador:

\begin{abstract}
Mais que uma narração de vivência própria durante sua missionação na África Centro-ocidental, seu trabalho é amplamente utilizado por qualquer estudioso que pretenda analisar a África Central no século XVII, sendo ainda uma espécie de história oficial dos primeiros 25 anos da presença da Ordem dos Frades Menores Capuchinhos na região. Por tudo isso, essa obra, por si só, tem uma dimensão extraordinária como fonte documental, reunindo, ainda que sob a pena de um indivíduo, pontos de vista de outros personagens históricos ${ }^{461}$.
\end{abstract}

Ao narrar as missões na região do Congo, Matamba e Angola, o Pe. Cavazzi citou vários rios, como o Zaire ${ }^{462}$, o Formoso ${ }^{463}$, o Cole $^{464}$, o Zenza ${ }^{465}$, o Lutato ${ }^{466}$, o Lucala $^{467}$, o Lufume ${ }^{468}$, o Lunino ${ }^{469}$, o Longa ${ }^{470}$, o Mbrige ${ }^{471}$, o Cuari ${ }^{472}$, o Bengo ${ }^{473}$, o

\footnotetext{
${ }^{459}$ Ibid., p.59.

${ }^{460}$ GONÇALVES, 2008, p. 09.

${ }^{461}$ Ibid., p. 10.

${ }^{462}$ MONTECÚCCOLO, 1965, livro quinto, p. 26.

${ }^{463}$ Ibid., livro quinto, p. 48.

${ }^{464}$ Ibid., livro sexto, p. 113.

${ }^{465} \mathrm{Ibid}$., livro sétimo, p. 178.

${ }^{466}$ Ibid., livro primeiro, p. 26.

${ }^{467}$ Ibid., livro sétimo, p. 181.

${ }^{468}$ Ibid., p. 186.

${ }^{469}$ Ibid., p. 212.

${ }^{470}$ Ibid., livro primeiro, p. 26.

${ }^{471}$ Ibid., livro sétimo, p. 187.

${ }^{472}$ Ibid., p. 195.

${ }^{473}$ Ibid., p. 188. 
Dande $^{474}$, o Ngango ${ }^{475}$, entre outros. Especial atenção recebeu o rio Cuanza, descrito como um "[...] rio caudaloso, que talvez não seja inferior ao Pó, em Itália"476.

Cavazzi destacou a proximidade entre as populações que viviam perto das águas e os portugueses. Ao abordar esse assunto, assim como em várias partes do seu relato, Cavazzi deixou clara sua visão de mundo:

Melhores disposições se encontram nas populações do litoral, das margens
dos rios navegáveis e das maiores cidades, onde residem os governantes,
pois, lidando frequentemente com portugueses ou com outros europeus,
são iluminados pela luz da civilização e por noções mais humanas e
razoáveis. 477

O Pe. Cavazzi e os demais capuchinhos realizaram trabalho missionário em várias regiões, o qual consistia, principalmente, no ensino do catecismo, na edificação de capelas, no erguimento de cruzes e na administração dos sacramentos, como a confissão, a unção dos enfermos, o matrimônio e o batismo.

Os capuchinhos acreditavam que a religião católica era a única verdadeira e consideravam idólatras as práticas e crenças tradicionais. Por isso, eles empenharam-se em destruí-las. Queimaram o que classificaram como objetos de idolatria, ridicularizaram os costumes, desrespeitaram tabus, perseguiram sacerdotes dos ritos tradicionais, ordenaram o espancamento de uma sacerdotisa, entre outras ações ${ }^{478}$. Essas atitudes provocavam ira e revolta nas populações locais e, em algumas ocasiões, ocorriam episódios violentos. Em um desses embates, o Pe. Cavazzi levou um golpe que the deixou uma cicatriz no rosto $^{479} \mathrm{e}$, em muitas ocasiões, correu o risco de ser morto. Por exemplo, em Maupungo, após queimar objetos, segundo seu relato, "[...] toda a gente correu para me matar, queixando-se daquela afronta feita aos ídolos, mas Nosso Senhor dominou o furor daqueles cegos, porque, apesar de terem as frechas nos arcos, não ousaram atirar" $^{480}$. Para Cavazzi, sua sobrevivência era explicada pela Divina Providência e

\footnotetext{
${ }^{474}$ Ibid., p. 188.

${ }^{475}$ Ibid., p. 242.

${ }^{476}$ MONTECÚCCOLO, 1965, livro quinto, p. 62.

${ }^{477}$ Ibid., livro primeiro, p. 87.

${ }^{478}$ Ibid., livro sétimo, p. 224.

${ }^{479}$ Ibid., p. 231.

${ }^{480}$ Ibid., livro sétimo, p. 225. 
pelo "[...] respeito que aquela gente tem para com os Portugueses". ${ }^{481}$

A presença portuguesa alterou o intrincado jogo de forças da região. Diferentes chefaturas, com poder desigual, fizeram escolhas diversas. Conforme Cavazzi, alguns chefes aceitaram o catolicismo, outros só o aceitaram para garantir as vantagens comerciais e militares decorrentes da relação com os portugueses e outros o recusaram abertamente.

Entre os que recusaram o batismo católico, podemos citar o chefe de Danji. Quanto aos que aceitaram o catolicismo, existiu uma grande diferença entre as posturas adotadas. Em alguns locais, segundo Cavazzi, parece não ter existido muita tensão entre os chefes africanos e os missionários católicos, tal como ocorreu nas relações no Congo Banga e no Haco, cujos chefes locais foram descritos como excelentes cristãos ${ }^{482}$. No entanto, em muitos casos, existiu uma clara oposição. Existiram chefes que fingiam colaborar, mas que empreenderam esforços para prejudicar o trabalho missionário. Esse foi o caso do chefe de Quitaxi, que roubou os mantimentos de Cavazzi e incentivou a população a se armar contra os capuchinhos $^{483}$. Também podemos citar o caso do chefe de Maupungo, Ngola-a-Ari. Ele foi batizado e permitiu que a região sob o seu domínio fosse evangelizada. Durante um período de cinco anos, a região contou com o trabalho de jesuítas e de padres seculares. Contudo, a adoção do catolicismo ocorreu apenas para que "[...] o governador de Luanda o julgasse bem-querente e bom católico" ${ }^{484}$. Cavazzi relatou o episódio ocorrido após o chefe de Maupungo pedir para que o sino da Igreja não fosse tocado, alegando que o seu toque incomodava a população, que não estava acostumada com a sonoridade:

\footnotetext{
Apesar dessa limitação, que respeitei cuidadosamente, para não excitar a serpente, conseguia convocar o povo para a santa missa. Mas uma manhã descobri que não era o repique do sino que dava incómodo, antes os próprios exercícios da religião: quando me preparava para vestir os paramentos sacerdotais, não encontrei nem o amicto nem o manípulo.

Por mais diligências que fizesse, nunca pude encontrar os objectos roubados nem descobrir o gatuno. Mas pouco depois descobri que naquele furto estava a mão do rei, obstinado nos seus delírios, especialmente em querer impedir-
}

\footnotetext{
${ }^{481}$ Ibid., p. 225.

${ }^{482}$ MONTECÚCCOLO, 1965, p. 187.

${ }^{483}$ Ibid., livro sexto, p. 130.

${ }^{484}$ Ibid., livro sétimo, p. 224. 
me a celebração. ${ }^{485}$

O chefe de Maupungo também apregoava que os capuchinhos "[...] mereciam o desterro como sediciosos e perturbadores dos costumes antigos" ${ }^{486}$. Nesse momento, Ngola-a-Ari parece ter tocado numa questão relevante, já que os cultos e crenças tradicionais eram utilizados pelos chefes africanos para garantir seu poder sobre a população. Por exemplo, uma das fontes do poder de Ngola-a-Ari advinha do domínio que exercia sobre os fenômenos atmosféricos. Conduzia cerimônias que provocavam chuva e, assim, conseguia garantir a fertilidade dos campos ${ }^{487}$. Dessa forma, Cavazzi, ao afirmar que não era Ngola-a-Ari que controlava as chuvas, e sim Jesus Cristo, abalava a autoridade do chefe africano.

Cavazzi também forneceu outro exemplo relacionado ao mesmo chefe africano. Na corte de Ngola-a-Ari, existiam dois ídolos, Guanzambumbo e Navieza, venerados pela população. Ao garantir a realização do culto a esses ídolos, o chefe de Maupungo garantia sua autoridade. Cavazzi, ao queimar os chamados ídolos, desequilibrou essa equação e provocou a revolta de Ngola-a-Ari e da população. As ações de Cavazzi foram sentidas como se "tivesse aconselhado uma revolução". Dessa forma, ao atacar os ídolos, abalou a dinâmica existente e as relações de poder, comprometendo o domínio do chefe africano sobre a população. No diálogo travado, entre o missionário e o chefe africano, diferentes visões de mundo e interesses foram confrontados. Conforme Cavazzi:

De facto, Ngola-a-Ari, ao repreender-me por ter provocado os guardas reais e toda a população, deu-me ocasião de eu o repreender também, porque, em vez de impedir aquelas hediondezas as sustentava, sob pretexto de privilégios, apesar de não serem mais do que abusos contra a religião cristã, que ele professava. Não soube ele aduzir outra desculpa senão a de que, para manter obediente um reino aliado e útil aos Portugueses, era preciso dissimular alguma coisa. Repliquei-lhe que uma coisa que dizia respeito a Deus precisava de pulso e coragem de rei, e não de enredos políticos, mas ele insistiu em que era impossível tirar aqueles ídolos, que havia tanto tempo estavam em Maupungo, venerados pelos naturais. Não cedi, antes insistia na minha proposição, dizendo que, se os naturais de Maupungo quisessem ser considerados verdadeiros católicos, deviam necessariamente adorar o único e verdadeiro Deus ${ }^{488}$.

\footnotetext{
${ }^{485}$ Ibid., livro sétimo, p. 226.

${ }^{486}$ MONTECÚCCOLO, 1965, p. 230.

${ }^{487}$ Ibid., livro segundo, p. 199.

${ }^{488}$ Ibid., livro sétimo, p. 222. 
O chefe de Maupungo já tinha sido batizado, portanto, era cristão. No entanto, continuava praticando os cultos tradicionais sob a alegação de que a permanência desses cultos garantia a subordinação da população e, portanto, forneceu razões práticas para justificar escolhas religiosas. Defendeu a necessidade de dissimulação, ou seja, a permissão para a prática de uma falsa religião para garantir a manutenção da ordem. No entanto, levando-se em consideração suas ações anteriores, contrárias ao catolicismo, parece que o chefe de Maupungo se dissimulava para Cavazzi, ou seja, na realidade, era adepto dos cultos tradicionais e sua conversão ao catolicismo era apenas por razões práticas. Carregava um grosso terço, mas o que tinha "no coração só Deus o sabe"489. Seja lá no que acreditava, existiam razões práticas para a realização de ambos os cultos - tradicionais e católicos. Assim, para obter o apoio português e garantir o domínio sobre a população, Ngola-a-Ari lidou com as tradições europeias e africanas.

No campo político, Ngola-a-Ari consolidou sua aliança com os portugueses e foi escolhido por eles para ser o chefe do Dongo. Essa era a posição política que Jinga, que se tornaria chefe de Matamba, tanto almejava. Jinga, também, teve que se movimentar neste tabuleiro, do qual o catolicismo e as crenças tradicionais faziam parte.

Embora adepta dos cultos tradicionais, Jinga fez concessões à religião dos portugueses. Alguns chefes africanos foram bem mais hostis. Talvez, entre os chefes que foram batizados, o mais hostil aos missionários católicos tenha sido o imbangala Cassanje. Ele deixou claro que o batismo tinha significado apenas na esfera política, ou seja, apenas "[...] para que os Portugueses não interrompam o comércio e não the façam guerra" ${ }^{490}$. Em muitas ocasiões, desprezou, questionou, provocou e ironizou os missionários e a fé cristã. Por exemplo, um dia após ser batizado, já estava praticando um dos atos que mais chocavam os missionários católicos - a antropofagia. Lourenço de Aragão, parente de Cassanje, testemunhou com espanto essa cena. Conforme Cavazzi:

Cassanje disse-lhe cinicamente que compreendia muito bem a sua

\footnotetext{
${ }^{489}$ MONTECÚCCOLO, 1965, p. 222.

${ }^{490}$ Ibid., p. 217.

127
} 
desaprovação, mas, como aceitara o baptismo por política, e não por convicção, guardara interiormente a sua liberdade de não submeter àquela tão rigorosa proibição de comer carne humana, pois todas as outras comidas Ihe pareciam sem sabor e não convenientes à sua compleição física ${ }^{491}$.

Cassanje não acreditava que o Deus católico protegia os cristãos. Numa ocasião em que estavam reunidas muitas pessoas, fez o seguinte questionamento a Cavazzi: "Porque é que a lei que vós divulgais como certa e verdadeira não preserva das doenças, das desgraças e da morte aqueles que a praticam"492. Enfatizou que as conquistas do seu povo não se deviam aos Deus católico (o Nzambi dos portugueses) e sim aos seus deuses, aos seus mortos e aos seus vivos, os quais também serão os responsáveis por glórias futuras: "Nós conquistamos Ganguela e mais outras províncias sem o vosso Nzambi e estamos certos de conquistar mais outras regiões no futuro, com a ajuda dos nossos deuses, dos nossos falecidos e com o valor dos nossos soldados". ${ }^{493}$

Para Cassanje, a religião católica era falsa porque os mortos se comunicavam com os sacerdotes africanos, e não com os missionários católicos. Além de pregarem uma religião falsa, Cassanje desaprovava o fato de os missionários serem europeus. Considerava as ações dos capuchinhos uma intromissão de estrangeiros em assuntos internos. Quando Cavazzi recebeu a mensagem que teria que partir, foi se despedir de Cassanje. Também aproveitou para informá-lo que seria substituído por outro capuchinho. Cassanje ficou satisfeito com a partida de Cavazzi, dizendoIhe que "fosse à fava". Quanto à chegada de outro missionário, afirmou:

Capuchinho o que se foi! Capuchinho o que veio! Capuchinho o que virá! Esses capuchinhos pretendem muita coisa, mas ver-se-á o que conseguirão. Por mim, protesto que sempre odiarei a sua doutrina e enquanto não chegar um padre natural da Etiópia nem eu descansarei, nem os meus súbditos ficarão satisfeitos. ${ }^{494}$

Segundo Cavazzi, numa outra atitude de provocação, Cassanje mandou espalhar entranhas num lugar pelo qual passaria uma procissão, "demonstrando

\footnotetext{
${ }^{491}$ Ibid., livro sétimo, p. 203.

${ }^{492}$ MONTECÚCCOLO, 1965, p. 210.

${ }^{493}$ Ibid., p. 210.

${ }^{494}$ Ibid., p. 212.

128
} 
assim o seu sentimento e o escárnio que faz das correções dos padres"495. Cassanje e Cavazzi possuíam visões de mundo tão divergentes que Cavazzi tinha dificuldade em classificá-lo. Com o acirramento da tensão, contrariando sua convicção de que "nunca se deve desesperar da conversão de qualquer pecador"496, parece que Cavazzi perdeu as esperanças. Ele concluiu: "Até agora julguei-o renegado, mas agoro julgo-o ateu, por adorar o que lhe diz o capricho, sem distinção duma ou doutra forma de idolatria". 497

Assim como Cassanje, Jinga e Ngola-a-Ari, cada chefe africano movimentouse de uma determinada forma no novo cenário inaugurado com a chegada dos portugueses. Cavazzi destacou que a forma como o chefe africano lidava com o catolicismo contribuía, significativamente, para definir como a doutrina seria seguida pela população. Por exemplo, Jinga, que no fim da vida atuou como católica e protegeu os missionários, ao participar com fervor de cultos e procissões católicas, servia de modelo para o seu povo. Desse modo, o comportamento de Jinga era o melhor "argumento" e a "norma infalível de crer e de operar" ${ }^{498}$. Exemplos bem diferentes foram dados por Ngola-a-Ari, cujo "mau exemplo" foi seguido pelos seus subordinados $^{499}$ e, mais ainda, por Cassange, pois "[...] a pública transgressão do chefe justificava também a dos súbditos"

\footnotetext{
${ }^{495}$ Ibid., livro sétimo, p. 216.

${ }^{496}$ Ibid., livro quinto, p. 83.

${ }^{497}$ MONTECÚCCOLO,1965, livro sétimo, p. 216.

${ }^{498}$ Ibid., p. 124.

${ }^{499}$ Ibid., livro sétimo, p. 226.

${ }^{500}$ Ibid., p. 203. 


\subsection{O catolicismo e as populações africanas}

A partir da missão do Congo, a qual definiu como a "missão mais bemsucedida na África", ${ }^{501}$ Thornton refletiu sobre o catolicismo praticado na região. Ele criticou os pesquisadores que consideravam as cosmologias africanas e européias antagônicas, tratando-as como fixas em vez de dinâmicas ${ }^{502}$. Thornton defendeu que no Congo ocorrera um processo de fusão de tradições, o qual gerara uma nova religião - o cristianismo africano. Sublinhou que africanos e europeus compartilhavam algumas ideias, as quais foram fundamentais para 0 desenvolvimento do cristianismo africano. Ambas as culturas acreditavam que existiam dois mundos diferentes, porém interligados: "este mundo", o mundo dos vivos, o mundo material, o qual poderia ser apreendido através dos cinco sentidos e o "outro mundo", habitado por uma variedade de entidades e seres, entre os quais, as almas dos mortos, o qual só poderia ser captado por pessoas com dons especiais.

Em ambas as tradições, era através das revelações que se tinha acesso ao "outro mundo" ${ }^{503}$. Ou seja, as revelações possibilitavam ter visão do "outro mundo" e a interpretação dessas revelações formaram as religiões. Por exemplo, o cristianismo foi criado a partir da interpretação de uma séria de revelações, as quais foram registradas nas Sagradas Escrituras ${ }^{504}$. Quanto às religiosidades africanas, também foram constituídas através da interpretação das revelações. As formas de ter acesso ao "outro mundo" eram as seguintes: presságio, adivinhação, interpretação dos sonhos e possessão ${ }^{505}$.

A fusão das tradições africanas e europeias foi um processo de troca e avaliação de revelações. No entanto, nem sempre africanos e europeus concordavam quanto à validade de uma determinada revelação. Os africanos tinham dificuldade de aceitar uma revelação ocorrida num passado longínquo. Por sua vez,

\footnotetext{
${ }^{501}$ THORNTON, John. A África e os africanos na formação do mundo atlântico, 1400-1800. Trad. De Marisa Rocha Motta. Rio de Janeiro: Ed. Campus; Elsevier, 2000, p. 338.

${ }^{502}$ Ibid., p. 335.

${ }^{503}$ THORNTON, 2000, p. 313.

${ }^{504}$ Ibid., p. 316.

${ }^{505}$ Ibid., p. 317.

130
} 
os europeus, em muitas ocasiões, embora não duvidassem que a revelação africana fosse oriunda do "outro mundo", acusavam-na de possuir origem diabólica ${ }^{506}$.

Rotular uma revelação como originária do diabo foi uma das formas de controlar o processo de validação das revelações. Isso também aconteceu na Europa. No princípio do cristianismo, as revelações ocorriam num fluxo contínuo. No entanto, quando a Igreja foi cooptada pelo Império Romano sob Constantino, as revelações foram canonizadas. Resumidas na Bíblia, essas revelações passaram a formar a base inviolável do cristianismo e, assim, foi estabelecida uma ortodoxia ${ }^{507}$. As revelações contínuas continuaram ocorrendo, no entanto, um clero forte conseguiu garantir que as revelações contidas na Bíblia fossem vistas como as únicas verdadeiras. Na Época Moderna, um clero forte, aliado ao Estado, não hesitou em utilizar a violência para combater as revelações contínuas, sob a acusação de possuírem origem diabólica. Desse modo, os tribunais da Inquisição foram uma demonstração de força de um clero empenhado em combater tudo que destoasse da ortodoxia da Igreja ${ }^{508}$.

Diferentemente dos sacerdotes europeus, o poder dos sacerdotes africanos era bastante limitado. Os sacerdotes africanos viviam à mercê dos seus mantenedores, fossem eles poderosos ou pessoas simples. Esses religiosos deveriam, frequentemente, fornecer provas de sua capacidade de se comunicar com o "outro mundo". Caso falhassem, estariam sujeitos à rejeição, ao desprezo e a sofrer penalidades. Por exemplo, em 1563, o rei do Dongo acusou de fraude e ordenou a execução de onze sacerdotes (fazedores de chuva) que conduziram ritos propiciadores de chuva cujo objetivo não foi atingido ${ }^{509}$.

Os sacerdotes africanos não tinham poder para impor uma ortodoxia, ou seja, não tinham meios para obrigar a população a aceitar uma cosmologia uniforme ${ }^{510}$. No entanto, mesmo sem uma ortodoxia, criou-se uma cosmologia razoavelmente estável. Ao comparar as cosmologias do século XVII com as do século $X X$,

\footnotetext{
${ }^{506}$ Ibid., p. 317.

${ }^{507}$ Ibid., p. 328.

${ }^{508}$ THORNTON, 2000, p. 328-330.

${ }^{509}$ Ibid., p. 326.

${ }^{510}$ lbid., p. 325 e 327.

131
} 
pesquisadores modernos notaram muitas semelhanças ${ }^{511}$ - o "outro mundo" era habitado por quatro categorias de seres: ancestrais, divindades territoriais, espíritos menos elevados e espíritos perigosos. ${ }^{512}$

A ausência de ortodoxia facilitou a conversão dos africanos ao cristianismo. As revelações ocorriam aos africanos em um fluxo incessante e cada uma precisava ser validada. Num primeiro momento, muitas revelações africanas foram aceitas pelo clero europeu. Por exemplo, no Congo, logo após a conversão do mani Congo, em 1491, duas pessoas influentes sonharam com uma bela mulher que suplicava para que o cristianismo fosse seguido no Congo. Uma dessas pessoas encontrou uma pedra diferente e com o formato de uma cruz. Ao clero cristão foram pedidas explicações, e os eclesiásticos esclareceram que a bela mulher era a Virgem Maria. Se, sob a ótica cristã, a bela mulher e a pedra foram sinais de graça e milagre, portanto, revelações aceitas, também foram aceitas segundo o ponto de vista dos africanos, segundo os quais sonhos e pedras com formato incomum representavam presságios, portanto, uma forma aceitável de revelação. Para provar a veracidade dessa revelação, a primeira igreja edificada no Congo foi dedicada a Virgem Maria. A pedra passou a ser venerada e foi colocada dentro dessa igreja ${ }^{513}$.

Outro exemplo de interpretação aceita pelas tradições europeias e africanas foi o processo de fusão de divindades, ancestrais e seres de outro mundo, africanos, com os santos católicos europeus. Conforme Thornton: "[...] a fusão das divindades do Congo com os santos ou anjos católicos foi uma das partes do diálogo aberto por uma série de revelações cristãs africanas" 514 .

Embora o clero europeu tenha considerado muitas revelações africanas como de origem divina, grande parte delas foi julgada como de natureza diabólica ${ }^{515}$. Mesmo sem o reconhecimento do clero europeu, muitos africanos continuaram a aceitar muitas outras revelações como válidas. Desse modo, o cristianismo africano era diferente do cristianismo praticado na Europa. Para Thornton:

O cristianismo africano era aceito na África e na Europa em grande parte

\footnotetext{
${ }^{511}$ Ibid., p. 321.

${ }^{512}$ Ibid., p. 331.

${ }^{513}$ THORNTON, 2000 , p. 336-338.

${ }^{514}$ Ibid., p. 341.

${ }^{515}$ Ibid., p. 342.

132
} 
pela força de suas revelações, especialmente aquelas permitidas por ambas as tradições. É claro que não havia uma superposição total. Muitos africanos continuaram a apoiar sacerdotes, cujas revelações não faziam parte da tradição cristã ou não eram reconhecidas pela Igreja, e, embora muitos europeus aceitassem algumas revelações africanas, eles rejeitavam outras como demoníacas ${ }^{516}$.

De acordo com Thornton, no século XVII, a maioria das pessoas no Congo se identificava como cristã e era vista dessa forma pelos visitantes. Em muitas localidades, cruzes foram erguidas e capelas edificadas. Os congoleses carregavam rosários, sabiam rezar um mínimo de preces e responder a questões básicas sobre a fé. No entanto, a conversão ao cristianismo raramente envolvia uma mudança religiosa fundamental, pois elementos substanciais das religiões tradicionais africanas permaneciam ${ }^{517}$. Segundo Thornton:

Muitos participavam regularmente da missa quando era celebrada frequentemente milhares de pessoas corriam às capelas a céu aberto ou às cruzes rurais para ouvir a missa ou recitar o rosário. Batizavam seus filhos, dando-lhes nomes cristãos, usavam a cruz e se consideravam cristãos. No entanto, também continuavam a visitar os túmulos de seus ancestrais e a procurar por sorte, saúde e bênçãos. Respeitavam as divindades territoriais que ocasionalmente identificavam com os santos cristãos, mas outras vezes reverenciavam-nas separadamente. Caçavam as bruxas para destruí-las e resistiam às tentativas dos missionários de descrever todas essas atividades como feitiçaria ${ }^{518}$.

Iniciada no Congo, esta maneira de fundir crenças africanas e europeias expandiu-se pela África Central. Assim, o cristianismo africano "[...] penetrou em todas as regiões, embora somente no Congo e em áreas sob a administração portuguesa ele estivesse fortemente enraizado como parte da identidade local" ${ }^{15}$.

No entanto, há autores que discordam de Thornton. Para James Sweet, não ocorreu um processo de fusão e sim a coexistência de duas religiões distintas - a religiosidade tradicional e uma forma africana de apreensão do catolicismo. Ele assinalou que, frequentemente, eram as mesmas pessoas que praticavam ambas as religiões. Segundo Sweet:

\footnotetext{
${ }^{516}$ Ibid., p. 343.

517 THORNTON, John K. Religião e Vida cerimonial no Congo e Áreas Umbundo, de 1500 a 1700. In: HEYWOOD, Linda (org). Diáspora negra no Brasil. Tradução Ingrid de Castro Vompean Fregonez, Thaís Cristina Casson e Vera Lúcia Benedito. $1^{\text {a }}$ ed. São Paulo: Contexto, 2009, p. 94-95.

${ }^{518}$ Ibid., p. 95.

${ }^{519}$ Ibid., 2009, p. 96. 
I am not arguing that there were no Kongolese Christians. There were. But they were not just Christians. A more plausible theoretical explanation for Kongolese beliefs is that Christianity and indigenous Kongolese religion operated in parallel fashion, with the broad Central African cosmology still being the dominant religious paradigm for most Kongolese, especially in the process of conversion to Christianity ${ }^{520}$.

James Sweet enfatizou que apenas um número muito reduzido de revelações congolesas foram validadas pelos padres católicos. A grande maioria das revelações foram vistas como diabólicas. Isso representou um problema, pois os congoleses dependiam, rotineiramente, da validação das revelações para lidar com as questões do dia-a-dia, ou seja, "[...] the cosmology of Central Africa was built upon the necessity of continuous revelation" ${ }^{251}$.

James Sweet também frisou algumas diferenças fundamentais entre as cosmologias africanas e européias. Enquanto o catolicismo girava em torno de um Deus único e verdadeiro, as cosmologias africanas operavam de uma forma diferente. Havia uma variedade de espíritos ancestrais e divindades que interferiam no mundo temporal. Os espíritos dos ancestrais recentemente falecidos eram especialmente importantes nesse sentido. Por isso, "[...] rather than seeking to reveal the Christian God in Africa, studies of African religions should attempt to understand the specific utility of ancestral spirits and their relationship to man"522. Consequentemente, também não fazia sentido para os centro-africanos a idéia de céu para os bons e o inferno para os maus, pois, após a morte, o espírito ia para o mundo dos ancestrais ${ }^{523}$.

Os centro-africanos utilizavam a religiosidade para interferir em questões temporais, ou seja, "[...] a way of explaining, predicting, and controlling events in the world around them"524. Os rituais eram realizados para lidar diretamente com a ventura e a desventura, assim, buscava-se o auxílio de poderes espirituais para lidar com eventos como doenças, seca, fome, esterilidade, entre outros ${ }^{525}$. Para Sweet,

\footnotetext{
520 SWEET, James H. Recreating Africa: culture, kinship and religion in the African Portuguese World, 1441-1770. Chapel Hill: University of North Carolina Press, 2003, p. 113.

${ }^{521}$ Ibid., p. 110.

${ }^{522}$ SWEET, 2003, p. 107.

${ }^{523}$ lbid., p. 108.

524 Ibid., p. 108.

${ }^{525}$ Ibid., p. 108. 
essa era outra diferença fundamental entre centro-africanos e europeus. Enquanto os rituais africanos eram utilizados para lidar com questões temporais, no mundo ocidental essas questões eram tradadas numa outra esfera, a qual fora chamada de ciência. Desse modo, separadas para os europeus, religião e ciência estavam indissociavelmente entrelaçadas para os centro-africanos ${ }^{526}$. Nesse ponto, discordamos da afirmação de Sweet. Tal afirmação não se aplicava ao mundo europeu, pois essa separação só ocorreu, de fato, a partir do iluminismo no final do século XVIII. E também não se aplica ao catolicismo, o qual não se restringia ao culto a um "Deus único e verdadeiro". No catolicismo, questões temporais também eram abarcadas e os santos católicos desempenhavam papel muito relevante nesse assunto. Súplicas e promessas eram feitas com o objetivo de se conseguir a ajuda do santo para a resolução de algum problema do mundo material. ${ }^{527}$ Inclusive, alguns santos eram vistos como especializados em resolver determinadas dificuldades terrenas.

Todas as religiões - sejam as europeias, as africanas, ou qualquer outra preocupam-se com questões temporais e com o pós-morte, portanto, têm a mesma finalidade. Assim, discordamos de Sweet quando ele diz que as religiosidades europeias e africanas apresentavam finalidades distintas. Todas as religiões lidam com o imponderável e não é possível categorizá-las, pois, em termos de maior ou menor adequação no trato de questões temporais ou espirituais. Acreditamos que as razões para a adoção de determinada prática religiosa devem ser procuradas no contexto social, e não em questões intrínsecas à cosmologia. Apontando para essa direção, concordamos com Sweet quando ele relaciona o catolicismo com fatores de ordem prática, como a presença de sacerdotes. Ele ressaltou a importância do catolicismo na região do Congo e Angola e enfatizou que a situação era bem diferente nas áreas mais afastadas, as quais raramente contavam com a presença de padres. Além da insuficiência de padres, outra questão fundamental era o enraizamento das religiosidades tradicionais. Acreditamos que Thornton, ao defender a idéia de fusão, não deu a devida importância a esses dois aspectos fundamentais. Desta forma, concordamos com Sweet e entendemos que houve uma

\footnotetext{
${ }^{526}$ Ibid., p. 108.

${ }^{527}$ Embora relacionado a uma localidade distinta, ao Vale do Ribeira, um exemplo da forma como os santos eram vistos foi exposta no Livro de Tombo de Iguape (1816-1854), no qual o Senhor Bom Jesus foi definido como um porto seguro para as "necessidades temporaes, e espiritaes" dos devotos. 135
} 
reinterpretação do catolicismo conforme as crenças locais. Para ele, muitos elementos da doutrina, como os santos, a cruz, os sacramentos e o Deus católico, foram apreendidos segundo a ótica dos africanos. Por exemplo, muitos centroafricanos integraram o Deus cristão em seu panteão de deidades, no entanto, sem reconhecer sua supremacia ${ }^{528}$. Conforme Sweet:

[...] most Kongolese viewed Catholicism through their own distinct spiritual and cultural prisms, only gradually grasping the meaning of the Christian cosmos. Where contact between clergy and laity was irregular, the tenets of Christianity probably remained only a peripheral concern. European priests frequently made references to Kongolese "errors" in their understanding of the Catholic faith ${ }^{529}$.

Dentre os muitos "erros" de interpretação, "[...] perhaps the most significant was the one involving the Catholica sacrament of batism" ${ }^{250}$. Segundo Sweet, para os centro-africanos, ser batizado significava "comer sal". Assim, os centro-africanos se dirigiam aos missionários católicos e pediam, com grande fervor, para "comer sal".

${ }^{528}$ SWEET, 2003, p. 192-195.

${ }^{529}$ Ibid., p. 195.

${ }^{530}$ SWEET, 2003, p. 195. 


\title{
4.3 Batismo
}

$\mathrm{Na}$ África Central, o batismo estava associado ao sal. Em várias partes do seu relato, Cavazzi mostrou essa associação. Como primeiro exemplo, podemos citar o embate entre Cavazzi e Quilamba-Pandu ocorrido no Quilombo de Pombo (região governada pelo já citado Imbangala Cassenge). Quilamba-Pandu, após ser aconselhado a batizar seus filhos, respondeu ao missionário de forma provocativa e irônica. Abaixo, o referido trecho:

\begin{abstract}
Uma destas manhãs exortei o Quilamba-Pandu, chamado Bartolomeu, já baptizado pelo $\mathrm{Pe}$. Antonio de Serravezza, a não deixar tanto tempo os seus filhos sem o benefício do baptismo. Respondeu-me que já tinham comido bastante sal no ventre das suas mães, que o comiam também e que não precisavam mais. Mas querendo eu repreendê-lo dessa alusão engraçada, começou a falar de coisas tão sujas e enormes que eu, baixando os olhos, o deixei, procurando recomendá-lo a Sua Divina Majestade $^{531}$.
\end{abstract}

Em outro trecho do seu relato, Cavazzi chamou o batismo de "santo sal" e explicou o motivo dessa designação: "assim chamam eles ao baptismo". Assim, -a denominação "santo sal" parece ter sido criada pelos próprios africanos. Num outro trecho do seu relato, Cavazzi informou que o batismo foi chamado, primeiramente, de "cudia mungua", que significava "comer sal". Cavazzi explicou:

\begin{abstract}
A expressão "comer o sal", em vez de "baptizar-se", ainda hoje usada naquela parte da Etiópia, foi introduzida talvez pela dificuldade de encontrar naquela língua um termo próprio para exprimir os efeitos do baptismo, ou talvez fosse inventada pelos nativos, que, pela sua ignorância, atribuíam a essência do baptismo à simples cerimónia complementar do sal. Mas não deixa de ser perigosa esta impropriedade de linguagem ${ }^{532}$.
\end{abstract}

Nesse trecho, Cavazzi levantou algumas questões, como a complexidade do batismo e a dificuldade de traduzi-lo para as línguas nativas e para o universo cultural africano. Também questionou a origem do vocábulo "cudia mungua". Formulou duas hipóteses para o surgimento desse vocábulo: como criação dos missionários católicos, ou dos próprios africanos. Parece que Cavazzi pendia para a

\footnotetext{
${ }^{531}$ MONTECÚCCOLO, 1965, livro sétimo, p. 210.

${ }^{532}$ MONTECÚCCOLO, 1965, livro quarto, p. 353 
segunda hipótese, como no outro trecho citado, onde apontou os africanos como autores do vocábulo.

Gonçalves ressaltou que, para Anne Hilton, foram os carmelitas que fizeram a associação entre o batismo e o ato de comer sal, traduzindo o batismo para "curiamunga" (comer sal). Os padres derramavam água na cabeça das pessoas, recitavam o sacramento do batismo e, depois, davam um pouco de sal para que fosse engolido ${ }^{533}$. No entanto, um outro documento analisado por Gonçalves - o opúsculo Gentilis Angollae Fidei Mysteriis (catecismo escrito pelo jesuíta angolano Antonio do Couto S.J. e publicado, em 1661, pela Sagrada Congregação de Propaganda Fide) parece apontar para os africanos como os autores do vocábulo. Nesse documento, a doutrina católica é apresentada a partir de uma sequência de diálogos entre o mestre e seus discípulos. Sobre o batismo, o mestre informou: "[...] o primeiro Sacramento he o Bautismo, que vos outros dizeis: Comer sal de Deos"534. Desse modo, parece que foram os centro-africanos que traduziram o sacramento apresentado pelos missionários para o vocábulo "comer sal". E essa tradução não agradava Cavazzi, que a julgava perigosa e inadequada.

Na sequência do trecho anteriormente citado, Cavazzi continuou tecendo críticas ao termo criado:

Com efeito, um dia entrou na nossa igreja um preto muito satisfeito por ter, dizia ele, assegurado o Paraíso a uma criança, dando-lhe o baptismo antes de ela morrer.

Um dos nossos perguntou-lhe a maneira como administrara o sacramento e ele, passando por pessoa qualificada e muito inteligente, respondeu que, pondo um bocado de sal na boca da criança, proferia as palavras sacramentais: "Eu te baptizo em nome do Pai e do Filho e do Espírito Santo".

Portanto, para tirar da mente dos indígenas um erro de tantas consequências, os Capuchinhos procuraram substituir o primeiro vocábulo de cudia mungua, que quer dizer "comer sal", pelo vocábulo lusucululunguisi, que quer dizer "lavacro santo", e cuidaram de ensinar não só a maneira de administrar, em caso de necessidade, este sacramento, mas também em que consiste a essência do mesmo ${ }^{535}$.

No trecho acima, Cavazzi deixou ainda mais patente a sua insatisfação com o

\footnotetext{
${ }^{533}$ GONÇALVES, 2008, p. 108.

${ }^{534}$ Apud GONÇALVES, op. cit., p. 134.

${ }^{535}$ MONTECÚCCOLO, 1965, livro quarto, p. 353. 
vocábulo "comer sal". E, para evitar as "tantas consequências" que tal "erro" poderia provocar, os capuchinhos impuseram um novo vocábulo e o batismo passou a ser traduzido como "lavacro santo", ou seja, "banho santo". Cavazzi, assim, evidenciou o quanto os capuchinhos sentiam-se incomodados com a associação entre batismo e sal e o desejo de criar uma nova associação. Como o elemento essencial num banho é a água, parece que os missionários pretendiam estabelecer uma nova associação: o batismo e a água.

Em outro trecho do relato de Cavazzi, essa vinculação entre o batismo e a água é ainda mais evidente. Ele relatou um fato ocorrido com o Pe. Antonio de Gaeta que, ao caminhar pela mata, ouvira um choro. Descobrira que o choro provinha de uma criança, a qual estava acompanhada de sua mãe. Elas estavam quase morrendo de tanto cansaço. A mãe da criança explicara que era cativa de um português de Massangano, no entanto, tinha sido enviada para outra fazenda, onde "todos eram tratados tão barbaramente" que preferia ser devorada por feras a ter que voltar. Ao ouvir isso, o Pe. Antonio de Gaeta:

Procurou confortá-la, prometendo que intercederia por ela junto do patrão. Depois perguntou-lhe se a menina era baptizada. Respondeu que não e que por isso o seu sofrimento era ainda maior, mas não encontrara ninguém que Ihe assistisse, pois nem água havia naquele lugar.

Enternecido, o padre mandou explorar se havia água naquelas partes, mais inùtilmente. Suplicou então a Nosso Senhor para que socorresse aquela alma mediante um prodígio da sua omnipotência. Entretanto deu-lhe alguma coisa de comer, para que refizesse as forças, e mandou que a ajudassem a andar devagarinho atrás dele. Pouco mais longe encontraram alguns pretos, um dos quais levava às costas um odre de água. Pararam então e o padre baptizou aquela criança, que, logo depois do baptismo, expirou, voando a sua alma toda cândida e inocente para o Céu ${ }^{536}$.

No anteriormente citado documento analisado por Gonçalves (o opúsculo Gentilis Angollae Fidei Mysteriis), também está presente a intenção de desfazer a associação entre o sal e o batismo e o desejo de vinculá-lo à água. Ao explicar o batismo ao seu discípulo, o mestre informou que esse sacramento "he aquelle lavatorio" no qual o sacerdote lança água sobre a cabeça do batizando e acrescentou: "Naõ he necessario deitarselhe o sal na boca: so a agua he necessaria: donde se lhe deitarem o sal na boca; \& Ihe naõ lançarem agua, naõ receberà o Bautismo. Daqui entenderàs, como errais vos outros em chamar o

${ }^{536}$ Ibid., livro sexto, p. 116. 
Bautismo, Comer sal de Deus"537.

No século XVII, a metáfora do sal foi muito utilizada na oratória sacra portuguesa, sendo o sal alimento da vida espiritual e antídoto à corrupção moral ${ }^{538}$. No entanto, na África, existia essa preocupação em não relacioná-lo ao batismo. Nessa complexa rede de significados e traduções há dúvidas acerca da visão dos africanos sobre esse sacramento. Cavazzi destacou a necessidade dos adultos receberem instrução religiosa para compreenderem a "essência do batismo". Como os ensinamentos eram realizados nos idiomas locais, a presença dos intérpretes era imprescindível. Conforme Cavazzi, era necessário "[...] empregar intérpretes, de maneira que era preciso repetir mil vezes a mesma coisa para que fosse fielmente traduzida, sem equívoco" ${ }^{539}$.

No trecho citado, está presente a questão das traduções linguísticas e simbólicas. Extrapolando o problema da tradução linguística, a necessidade de "repetir mil vezes a mesma coisa" revela o quanto foi difícil para os missionários impedir que o cristianismo fosse visto segundo as lentes africanas. Se os missionários precisavam insistir para que fosse feita uma tradução fiel, "sem equívoco", era porque isso não ocorria. Ou seja, a tentativa dos missionários de impor o seu olhar e negar o olhar do outro era, frequentemente, malsucedida.

Em outro trecho do seu relato, Cavazzi mostrou como o batismo era explicado aos centro-africanos: "Depois de benzida a água baptismal, o padre prefeito explicou ao povo as figuras, os mistérios e os efeitos da mesma, e o intérprete traduziu as suas palavras, acrescentando mais comparações, conforme o génio dos ouvintes" 540 . Em comparação com trecho anteriormente citado, essa passagem revela menos tensão. Cavazzi parece aceitar o olhar ("gênio") africano e a contribuição do intérprete ("acrescentando mais comparações") ao processo de traduções linguísticas e simbólicas.

Outro fato relevante era a grande quantidade de pessoas que pediam para ser batizadas. O Pe. Jerônimo de Montesárchio relatou que "[...] viu, às vezes,

\footnotetext{
${ }^{537}$ apud GONÇALVES, 2008, p. 135.

${ }^{538}$ MARQUES, 2005, p. 351.

${ }^{539}$ MONTECÚCCOLO, 1965, livro quarto, p. 352.

${ }^{540}$ MONTECÚCCOLO, 1965, livro terceiro, p. 278. 
prostradas aos seus pés, quinhentas e seiscentas pessoas de ambos os sexos e de todas as idades, pedindo-lhe com lágrimas o santo baptismo" ${ }^{541}$. Um outro exemplo foi dado por Cavazzi ao relatar a viagem de missionários capuchinhos para a região de Bata. Continuamente, os missionários encontravam "[...] grupos de duzentas até quinhentas pessoas que com grande instância pediam o baptismo" ${ }^{\text {"42 }}$. Cavazzi acrescentou: "Logo que se espalhou o boato da chegada dos novos missionários, acorreu povo inumerável, até da distância de 25 ou 30 léguas" ${ }^{543}$. Eles vinham em grande número e desejavam ser prontamente batizados, mas não compreendiam a necessidade de instrução religiosa. Conforme Cavazzi:

\begin{abstract}
Havia muitos impacientes que resmungavam, dizendo que partiriam sem mais, de maneira que, para os não perder, era preciso dissimular queixas e achar logo um pretexto para sossegá-los. Outros, não compreendendo a necessidade de instrução religiosa, como se a graça do baptismo fosse uma coisa exterior e material, queixavam-se contra os missionários e, pensando que estes adiavam os actos do seu ministério para os enganar e não por necessidade, acrescentavam que assim ofendiam o seu desejo de serem cristãos e por isso queriam voltar para as suas casas.
\end{abstract}

Outros diziam abertamente "Porquê tantas cautelas e tantos exames sobre a seriedade dos nossos propósitos e sobre o que devemos acreditar? Não viemos espontâneamente? Não chegámos cá para comer todo o sal que Ihes aprouver dar-nos, como os outros brancos? Porquê e para quê tantas dificuldades?",544

Dessa forma, muitos centro-africanos ansiavam receber o batismo e relacionavam esse sacramento com o ato de comer sal. Por sua vez, os missionários incomodavam-se com a forma como o batismo era apreendido - "como se a graça do baptismo fosse uma coisa exterior e material" - e com a "perigosa" associação com sal. Assim, ficamos com as seguintes dúvidas: Por que os centroafricanos desejavam tanto o batismo? Por que a associação com o sal era tão perigosa?

O sal era um produto muito importante para os centro-africanos. Em Quissama, num vale profundo, perto da foz do rio Cuanza, existiam minas de sal. Uma água salgada brotava após o terreno ser cavado e o sal era obtido após a evaporação da água. Esse sal era conhecido como pedra de Quissama. Em

\footnotetext{
${ }^{541}$ Ibid., p. 413.

${ }^{542}$ Ibid., p. 352.

${ }^{543}$ Ibid., p. 352.

${ }^{544}$ Ibid., p. 352-353. 
Benguela, também existiam minas desse mineral ${ }^{545}$.

Gonçalves sublinhou que, segundo Birmingham, os Imbangalas foram atraídos para a região de Angola com o objetivo de explorar o sal ${ }^{546}$. Essa mesma autora destacou que, quando os portugueses chegaram em Angola, o principal produto comercializado foi o sal de Quissama ${ }^{547}$. Cavazzi destacou a comercialização do sal de Quissama, vendido nos mercados "em grande quantidade", e também do sal de Benguela, o qual era "[...] carregado em numerosas naus para Luanda"548. A importância econômica do sal, também, pode ser inferida pelo fato de a Coroa Portuguesa ter garantido o monopólio do comércio de sal a Paulo Dias, o fundador da colônia portuguesa em Luanda ${ }^{549}$.

Além da importância econômica, Cavazzi destacou o uso medicinal do sal de Quissama: "Este sal é muito útil nos usos domésticos e em medicina, por ser diurético" 550 . Por sua vez, Sweet enfatizou a importância do sal na esfera espiritual: "In Kongolese tradicional belief, salt was thought to be a repellent of evil people and

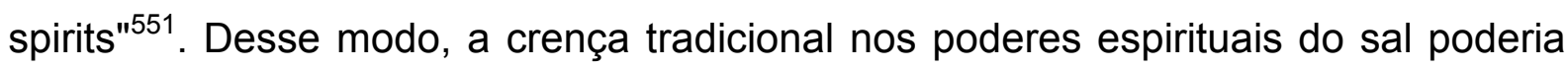
ter motivado um grande número de centro-africanos a pedir o batismo. E essa apreensão africana do batismo descontentava os missionários católicos, os quais, repetidamente, falavam em "equívocos" e "perigos" decorrentes de "erros de tradução". Portanto, o esforço dos capuchinhos para desconstruir a associação entre o sal e o batismo pode ser explicado pelo fato de estarem cientes da crença tradicional no poder espiritual do sal.

Para Sweet, o batismo foi interpretado conforme as lentes cosmológicas centro-africanas. Por meio delas, o sacramento era visto como uma forma de proteção contra o mal e não como o caminho para a purgação dos pecados e salvação eterna da alma ${ }^{552}$. Conforme visto anteriormente, para os centro-africanos, o mundo espiritual intervinha em questões temporais Assim, o batismo foi visto como um remédio para lidar com as desventuras do mundo temporal. Para demonstrar

\footnotetext{
${ }^{545}$ MONTECÚCCOLO, 1965, livro primeiro, p. 23-24.

${ }^{546}$ GONÇALVES, 2008, p. 34.

${ }^{547}$ Ibid., p. 32.

${ }^{548}$ MONTECÚCCOLO, op.cit. livro primeiro, p. 23-24.

${ }^{549}$ GONÇALVES, op. cit., p. 32.

${ }^{550}$ MONTECÚCCOLO, op. cit., livro primeiro, p. 23.

${ }^{551}$ SWEET, 2003, p. 195.

${ }^{552}$ SWEET, 2003, 196. 
isso, Sweet citou a forma como o batismo foi entendido por cativos centro-africanos que desembarcaram na América no começo do século XVII. Esses cativos, antes do embarque em Luanda, participaram de um rito de batismo coletivo. Em três ou quatro horas, por volta de 700 escravizados foram batizados. Os fundamentos da doutrina católica não foram ensinados. Na cerimônia de batismo foram observadas três etapas: primeiramente, foi dito e escrito o nome cristão de cada batizando. Depois, foi colocado sal na boca de cada um. Para concluir, foi jogada água na cabeça dos cativos $^{553}$. Ao serem questionados sobre o que compreenderam do rito, conforme Sweet:

\begin{abstract}
Some slaves quite literally said that they thought of their baptism as a "thing of witchcraft" in order for the Europeans "to eat them". Others responded that the ceremonies were to prevent them from having sex with the slave women during the Middle Passage. Others believed that the water would protect them from illness. And still others thought that the water was to "enchant" them so that they would not rise against the whites, on board the ship. None of the slaves understood their baptism as a washing away of $\sin$. Thus, for the majority of Central Africans, their first exposure to Christian rituals were seen through the prism of their temporal misfortunes. ${ }^{54}$
\end{abstract}

O batismo foi visto como um rito praticado pelos europeus com o objetivo de "encantar" e dominar os africanos. Foi interpretado como a essência do poder espiritual dos europeus. Assim, "[...] to be 'like the other whites', with their economic and social power, meant embrancing their most potent religious ritual: baptism" ${ }^{555}$.

Além de ser o rito que garantia acesso ao poder dos europeus, receber o batismo também era visto como algo que conferia prestígio social. Para Cavazzi, muitos africanos queriam ser batizados porque a realização de um rito praticado por europeus era um sinal de distinção social, ou seja, indicava que as pessoas que já tinham sido batizadas ocupavam posição social elevada. Por exemplo, Cavazzi, na missão de Maupungo, fez o seguinte comentário sobre os moradores de Dumbi: "[...] embora praticassem ainda a idolatria, traziam-nos as suas crianças para que eu as baptizasse, pois tinham em grande estima o nome de cristão" ${ }^{556}$. Cavazzi também sublinhou que os habitantes de Polongolo, na Pequena Ganguela, tinham "[...] um desejo superficial ou, melhor, uma ambição de ser cristã, para imitação dos

\footnotetext{
${ }^{553}$ Ibid., p. 196-197.

${ }^{554}$ Ibid., p. 197.

${ }^{555}$ Ibid., 196-197.

${ }^{556}$ MONTECÚCCOLO, 1965, livro sétimo, p. 222. 
Europeus"557. Ele destacou que "[...] pertencer ao número dos fiéis era já considerado uma honra tão grande, que mesmo aqueles que adiavam o baptismo para não abandonarem os seus vícios tinham vergonha de aparecer diferente dos outros e fingiam-se cristãos" ${ }^{258}$.

Assim, interesses comerciais, militares e políticos, associados à busca de prestígio social e misturados com motivações espirituais - sejam essas motivações relacionadas com uma nova religiosidade (cristianismo) e/ou uma religiosidade tradicional - combinaram-se e confluíram para a centralidade do batismo na África Centro-Ocidental.

Peça-chave na relação entre europeus e africanos, mesmo pesquisadores céticos quanto ao catolicismo praticado nessa região como Sweet enfatizaram a importância do batismo. Cavazzi citou o número de batizados para ilustrar as conquistas do trabalho missionário. Por exemplo, o padre Ângelo batizou seiscentas almas $^{559}$; o padre Bernardino de Roca, cerca de mil e duzentas almas ${ }^{560}$; o padre Antônio Gaeta, mais de oito mil almas em menos de seis anos ${ }^{561}$; o padre João Francisco da Fábrica, mais de oito mil almas ${ }^{562}$; o padre Felipe de Sena, catorze mil almas entre os anos de 1655 e $1654^{563}$.

Ao rito praticado com água e sal, muitos significados e sentidos foram atribuídos. Conforme Cavazzi assinalou, o batismo significava renascimento. Simbolicamente, o batizando morria e renascia no mundo cristão. Ou seja, o batismo era o rito de passagem para a entrada na comunidade cristã.

Era também rito que protegia e trazia alívios às desventuras da vida, como a escravidão e a travessia atlântica. Praticado muitas vezes coletivamente e antes do embarque, o batismo foi o rito de passagem de outro, também praticado com água e sal - a Travessia Atlântica.

\footnotetext{
${ }^{557}$ Ibid., p. 210

${ }^{558}$ Ibid., livro sexto, p. 144.

${ }^{559}$ Ibid., livro quinto, p. 24.

${ }^{560}$ Ibid., p. 26.

${ }^{561}$ lbid., p. 177.

${ }^{562}$ Ibid., p. 179,

${ }^{563}$ Ibid., livro sétimo, p. 182. 


\section{Capítulo 5 - Institucionalização do Catolicismo no Vale do Ribeira}

O Padroado fazia do reino português o patrono das missões católicas na África, na Ásia e no Brasil. Então, Portugal, assim como se preocupou com a evangelização dos povos da África Central, empenhou-se na conversão dos povos que habitavam o outro lado do Atlântico. Esses povos deveriam se sujeitar ao poder temporal do monarca português e ao poder espiritual do papa.

No Brasil, os primeiros organizadores do catolicismo foram os jesuítas ${ }^{564}$. Conforme exposto anteriormente ${ }^{565}$, eles foram os primeiros religiosos que chegaram a Iguape. O primeiro foi Pedro Correa. Durante sua permanência em Iguape, iniciou a edificação de uma igreja. O Livro de Tombo dessa igreja foi aberto em $1577^{566}$ e Nossa Senhora das Neves foi escolhida como orago. Nos anos vindouros, nos séculos XVII e XVIII, outras missões da Companhia de Jesus visitaram a região de Iguape. A Câmara de Iguape enviou ofícios a Roma para agradecer pelas missões recebidas. Os padres da Companhia de Jesus atuaram na região até o ano de sua expulsão do Brasil, em $1759^{567}$. Quanto a essa última missão, segundo Serafim Leite: "[...] os padres Antonio de Souza e José Machado, foram por terra, desde Santos, dando missões nos lugares do percurso, sobretudo em Iguape e em Cananéia, com incríveis trabalhos e também fruto espiritual, que um deles conta em extensa relação" 568 .

Em 1647, um outro jesuíta, Padre Antonio da Cruz, ouviu do vigário da llha de

\footnotetext{
${ }^{564}$ SOUZA, Laura de Mello e. O diabo e a terra de Santa Cruz: feitiçaria e religiosidade popular no Brasil colonial. São Paulo: Companhia das Letras, 2009, p. 86.

${ }^{565}$ Capítulo 1 - item 1.3 - Rio da Fertilidade.

${ }^{566}$ No Livro de Tombo de Iguape (1816-1854), em 1819, o padre João Chrysostomo de Oliveira Salgado Bueno não fez nenhuma menção a esse Livro de Tombo aberto em 1577. No entanto, ele fez referência a um outro Livro de Tombo: "[...] pelo que achei no antigo Livro ja bem velho, do Tombo desta Freguezia, feito em 5 de junho de 1767 pelo Reverendo Vigario Antonio Ribeiro, esta Freguezia subsistia já a cento e setenta annos, pelo q.(e) se vê que seria fundada nos annos de 1577". Numa outra passagem, também escrita em 1819, o vigário João Chysostomo destacou que "não existem os antigos Livros. He de supor que se queimarão em hum incendio em Caza do Reverendo Vigario Antonio Ribeiro, hade haver mais de setenta anos, segundo me dizem: do antigo Livro de Tombo nada consta".

${ }^{567}$ LEITE, Serafim. História da Companhia de Jesus no Brasil. Vol. 6. Lisboa: Livraria Portugalia 1938 , p. 433-436.

${ }^{568}$ Ibid., p. 436. 
São Sebastião, Manuel Gomes, um relato importante para a história de Iguape. O vigário Gomes afirmou que viu "[...] passar pelo mar da parte do Norte para a do Sul (...) seis luzes hua noite, cuja luzerna alumiava grande circunferência" ${ }^{669}$. A circunferência de luz emanava da Imagem do Senhor Bom Jesus, que rolava pelas águas do mar até, por fim, parar nas proximidades de Iguape. A Imagem foi levada para a igreja de Iguape e, desde então, passou a ser venerada. A devoção ao santo extrapolava os limites da Vila e ele tinha devotos no Médio, no Alto e até mesmo fora do Vale do Ribeira. De acordo com o pároco, os devotos:

[...] concorrem de todas as partes em romarias, e dão muitas esmolas. Contão-se innumeraveis favores, e alguns prodigios que este Senhor se tem dignado dispensar aos fiéis, não só moradores desta Villa, como ainda aos mais longínguos; que devotamente se recorrem a elle em suas tribulações; cuja fama se tem estendido á toda parte, e por toda parte se venera esta verdadeira Efigie do Redemptor do mundo. ${ }^{570}$

Muitos anos depois, em 1819, o padre de Iguape destacou a importância da festa em homenagem ao santo, realizada no dia 06 de agosto: "A festa se faz á seis de Agosto com a possível grandeza, concurso de immensos romeiros, e fôrasteiros, devoção, e alegria geral; em fim pode-se dizer, que he este o dia do triunfo de Iguape" ${ }^{571}$.

O culto ao Senhor Bom Jesus ocupava papel central na vida religiosa local. No Brasil, até a época do Império, o culto aos santos foi um dos principais veículos de propagação do catolicismo. Os cultos aos santos eram organizados pelas irmandades religiosas ${ }^{572}$. Conforme Marina de Mello e Souza:

Diante do pouco investimento da Coroa portuguesa na construção de templos e da insuficiência de sacerdotes que suprissem as necessidades religiosas dos colonos, dispersos por grandes extensões territoriais, principalmente a partir do século XVIII, desenvolveu-se na América portuguesa um catolicismo fundado em torno de irmandades, que investiam na construção das igrejas e assumiam várias responsabilidades religiosas, principalmente as relativas ao culto de seus oragos ${ }^{573}$.

\footnotetext{
569 Livro de Tombo de Iguape (1816-1854), no qual foi transcrito o relato realizado em 1740 pelo Reverendo Christovão da Costa e Oliveira (Vigário da Vara da Vila de Paranaguá) na sua visita à Vila de Iguape.

${ }^{570}$ Livro de Tombo de Iguape (1816-1854).

${ }^{571}$ Livro de Tombo de Iguape (1816-1854).

572 REIS, João José. A morte é uma festa: Ritos fúnebres e revolta popular no Brasil do século XIX. São Paulo: Cia. Das Letras, 1991, p. 59.

573 SOUZA, Marina de Mello. Reis Negros no Brasil escravista: História da Festa da Coroação de Rei 146
} 
E ainda:

\begin{abstract}
As irmandades foram elementos fundamentais no exercício de uma religiosidade colonial e barroca, caracterizada pelo culto aos santos, pelas devoções pessoais e pela pompa das procissões e festas, marcada pela grandiosidade das manifestações exteriores da fé, na qual conviviam elementos sagrados e profanos ${ }^{574}$.
\end{abstract}

Existiam muitas irmandades em Xiririca e Iguape. Assim, essas localidades, com suas irmandades, festas e procissões, davam mostras dessa religiosidade típica do período colonial. Manifestações dessa religiosidade foram descritas nos Livros de Tombo de Iguape e Xiririca.

Os Livros de Tombo de Xiririca e Iguape foram abertos por ordem de Joaquim Julio da Ressureição Leâl (Reverendo de Paranaguá e Visitador da Vila de Iguape), ao visitar Iguape e Xiririca em 1816. Esses documentos estão associados à história oficial dessas localidades e foram elaborados por párocos, ou seja, pessoas detentoras de poder e prestígio social mais interessadas em retratar "os feitos memoráveis" e as "pessoas mais notáveis" do que as tensões sociais. Os conflitos entre os diferentes segmentos da sociedade estavam nas entrelinhas. Aqueles que eram descritos ocorreram entre os "homens mais conceituados", assim, até os oponentes, de certa forma, foram valorizados. Escravizados e seus descendentes ocuparam um papel menor nos relatos. A ligação entre a história do poder e os Livros de Tombo pode ser notada por meio das recomendações dadas pelo reverendo de Paranaguá. No Livro de Tombo de Iguape (1816-1854), ele sublinhou que deveriam constar "[...] tudo mais que houver de memoravel athe oje, e que fôr sucedendo p'ara o futuro, para conservar-se na memoria dos vindouros, escapando da edáde dos Tempos". Para o Livro de Tombo de Xiririca (1816-1898), determinou que estive presente "tudo o mais notavel q' tem acontecido desde a fundação da igreja" e "[...] o que for acontecendo de hoje em diante de mais memoravel, para se não perder os acontecidos feitos, da Lembrança dos homens".

O Livro de Tombo de Iguape deveria especificar a origem da localidade, os limites territoriais, a população, as alfaias e os altares. Os usos e direitos paroquiais também deveriam ser descritos e reunidos num regimento. $O$ reverendo de 
Paranaguá sublinhou que "[...] na delonga de Cento e sessenta, ou mais annos, q'ésta Igreja Subsiste, não tem havido thé agora Regimento Confirmado por Autoridade Eclesiastica; e somente se tem governado por Uzos, e Tradição"575. Antes de partir, o reverendo de Paranaguá desejava confirmar os direitos paroquiais elencados no livro.

Ao longo do tempo, diferentes vigários escreveram nesse livro. A maior contribuição foi realizada por João Chrysostomo d'Oliveira Salgado Bueno. Em 1807, ele foi nomeado vigário coadjutor. Nessa época, Diogo Rodrigues Silva era o vigário principal $^{576}$. Em 1820, como o pe. Diogo estava com oitenta anos e também muito doente, o pe. João Chrysostomo tornou-se o vigário principal da Vila de Iguape. Permaneceu no cargo até 1833, quando retornou a sua terra natal, Paranaguá. Em 1819, o Pe. João Chrysostomo escreveu a "Memória da Vila de Iguape", na qual consta, entre outras informações, a história da criação da freguesia, a edificação da matriz, seus ornatos, seus altares, suas capelas, suas irmandades e a "[...] milagrosa Apparição, da sempre respeitavel, e devotissima Imagem do Snr. Bom Jesus, que fáz a mayor gloria désta villa". ${ }^{577}$

Quanto a Xiririca, na época da visita do reverendo de Paranaguá, a freguesia estava aos cuidados do Reverendo Joze Francisco de Mendonça. Ele era natural da Ilha de Santa Catarina e "teve este Parocho a honra de ser Familiar" do bispo de São Paulo - D. Matheus d'Abreu Pereira. O Rev. Joze Francisco tomou posse da freguesia de Xiririca no dia 16 de novembro de 1806 como vigário encomendado e, no dia 20 de junho de 1809, numa cerimônia realizada na corte do Rio de Janeiro, foi confirmado e colado. Assim, nessa data, tornou-se o primeiro vigário colado da Freguesia de Xiririca ${ }^{578}$.

Em 1816, durante a visita fiscalizadora, o reverendo de Paranaguá, ao deparar-se com o Livro de Tombo que estava sendo utilizado pelo pároco, constatou

\footnotetext{
${ }^{575}$ Livro de Tombo de Iguape (1816-1854).

${ }^{576} \mathrm{Em} 1712$, a Vila de Iguape pertencia à Capitania da Conceição, cujo donatário era o Conde da Ilha do Príncipe. Num momento posterior, a Vila de lguape passou a ser subordinada à Vila de Paranaguá. Em 1797, a Vila de Iguape separou-se da Vila de Paranaguá e passou a constituir uma comarca independente, juntamente com a freguesia de Xiririca e a Vila de Cananéia. Ao tomar posse da Igreja de Iguape no dia 26 de julho de 1780, o Reverendo Diogo Rodrigues Silva tornou-se o primeiro vigário da Comarca de Iguape. Livro de Tombo de Iguape (1816 -1854).

${ }^{577}$ Livro de Tombo de Iguape (1816 - 1854).

${ }^{578}$ Livro de Tombo de Xiririca (1816 - 1898).

148
} 
que o documento encontrado deveria se "[...] chamar confusa Micilania, e não Livro de Tombo" ${ }^{779}$. Ele sublinhou que o livro estava "[...] sem methodo, e só com desarãnjo e notavel desalinho [...]", "[...] cheyo de nodoas, e manchado, e porisso incapaz de continuar a servir, por embeber a tinta, e ficarem as letras apagadas, e se não entenderem nos Vindoiros tempos"580. O Rev. Leâl ordenou ao pároco de Xiririca, Jozé Francisco Mendonça, a abertura de um novo livro. Jozé Francisco deveria relatar a fundação da Freguesia, os fundadores, os limites territoriais, o nome dos bairros, as fazendas e engenhos mais notáveis, o número de fogos e de pessoas de confissão, o comércio, as plantações, as importações e as exportações. Ele deveria também descrever as igrejas, os santos venerados, as alfaias, o patrimônio da Igreja Matriz, os párocos, os costumes e a fundação da Capela filial de Ivaporunduva. O Reverendo de Paranagua destacou: "Bem sei, que este trabalho he grande, porem são mayores os talentos, e scientificos conhecimentos do M.R. Parocho actual" 581 . Assim, o vigário Joze Francisco Mendonça relatou os fatos que julgava serem os mais importantes e, também, copiou partes do antigo Livro de Tombo.

Desse modo, a partir dos Livros de Tombo de Iguape e Xiririca, com o objetivo de compreender a vida religiosa na região, abordaremos a fundação de capelas e igrejas e a atuação das irmandades.

\footnotetext{
${ }^{579}$ Livro de Tombo de Xiririca (1816-1898).

${ }^{580}$ Livro de Tombo de Xiririca (1816-1898).

${ }^{581}$ Livro de Tombo de Xiririca (1813-1898).

149
} 


\subsection{Igrejas e Irmandades de Iguape}

Em 1819, o vigário João Chrysostomo d'Oliveira Salgado Bueno sublinhou que "antigamente" existiam as seguintes irmandades: Irmandade do Santíssimo Sacramento, Irmandade da Senhora das Neves, Irmandade do Senhor Bom Jesus, Confrarias das Almas, Irmandade da Senhora do Rosário, Irmandade do Nome de Deos, Irmandade de São Miguel, Irmandade de Sancta Luzia, Irmandade da Senhora do Carmo, Irmandade de Sancto Antonio e Irmandade de São Sebastião. Em 1819, parece que existia um número menor de irmandades na Vila de Iguape. A Irmandade do Nome de Deos, de São Miguel, de Sancta Luzia, da Senhora do Carmo, de Sancto Antonio e a de São Sebastião deixaram de ser citadas. As Irmandades do Santíssimo Sacramento, da Senhora das Neves, do Senhor Bom Jesus, da Senhora do Rosário e a Confraria das Almas continuaram existindo. E uma nova irmandade tinha sido criada, a Irmandade de São Benedito.

Em Iguape, assim como em outras partes da América portuguesa, as irmandades seguiam a segmentação existente na sociedade, reunindo pessoas de determinadas categorias raciais e sociais, ou seja, "[...] agrupando as pessoas conforme a cor de sua pele e seu lugar na hierarquia social" ${ }^{252}$. As informações contidas nos Livros de Tombo de Iguape nos possibilitam visualizar os grupos sociais que compunham algumas de suas irmandades e, também, as divisões e tensões existentes na sociedade iguapense.

Conforme o vigário João Chrysostomo, os membros da Irmandade do Santíssimo Sacramento pagavam oito tostões por ano, e os irmãos de mesa pagavam o dobro desse valor. A irmandade possuía compromisso aprovado pelo Ordinário, o qual supunha que a irmandade existia desde o "principio desta Freguezia" ${ }^{583}$.

A Irmandade da Senhora das Neves, a santa padroeira de Iguape, era

\footnotetext{
582 SOUZA, 2002, p. 185.

${ }^{583}$ Livro de Tombo de Iguape (1816 - 1854). 150
} 
composta por "todos os Cazados" da localidade. A festa em sua homenagem acontecia em agosto. Os irmãos deveriam pagar cento e sessenta réis por ano, e os irmãos de mesa deveriam pagar trezentos e vinte réis. No entanto, conforme destacado pelo vigário, quando a anuidade era paga, era "de má vontade" e os mais míseros não pagavam, "[...] do que rezulta não ter patrimonio algum, e ser tão pobre, $q^{e}$ não chega o seu redito para pagar ao Parocho hûa Capella de Missas, que se diz nos Sabbados do anno, e ao Mestre da Capella por tocar órgão". O vigário concluiu que "[...] visto pois ter affrouxado a piedade, e o espirito com que foi creada esta Irmandade, hoje preciza de reforma, organizando-se de novo com Irmaons voluntarios, novos annuaes, Compromisso com approvação Regia, e alguns previlegios para assim affervorar a devoção" ${ }^{154}$.

A Irmandade do Senhor Bom Jesus, embora "[...] chamando-se Irmandade, não he; não tem Compromisso, nem Livro, em que se lancemos Irmaons, nem ha costume de pagar-se annual" ${ }^{585}$. Uma vez por ano, as pessoas mais distintas da vila, lideradas pelo pároco (capelão da irmandade), organizavam uma eleição para escrivão, tesoureiro e procurador. Também eram escolhidos os doze membros da mesa. Os eleitos ficavam responsáveis pelas "[...] alfaias, despeza, e economia da dita Irmandade, arrecadação das esmollas, e mais dinheiros da mesma, $\mathrm{q}^{\mathrm{e}}$ se guardão em hum Cofre com trez chávez"586.

Quanto à escolha do responsável pela festa do Senhor Bom Jesus, chamado de juiz, "[...] desde a epoca da collocação desta veneravel Imagem nesta Matriz, por ser esta Villa pobre [...]", existia o costume do juiz ser "tirado por sorte". Ou seja, era realizado um sorteio com "[...] trez sugeitos de fóra da Villa, que tenhão possibilidade para fazer a Festa". Raras vezes acontecia do sorteado não querer realizar a festa ou dar "pequena esmola, que não chegue para as despezas da Festa". Quando isso acontecia, a Irmandade encarregava-se de arrecadar grande parte, ou até mesmo a totalidade, dos recursos necessários para a festa realizada no dia seis de agosto ${ }^{587}$. A Irmandade do Senhor Bom Jesus encomendava uma "[...] capella de Missas", às

\footnotetext{
${ }^{584}$ Livro de Tombo de Iguape (1816-1854).

${ }^{585}$ Livro de Tombo de Iguape (1816-1854).

${ }^{586}$ Livro de Tombo de Iguape (1816-1854).

${ }^{587}$ Livro de Tombo de Iguape (1816-1854).

151
} 
sextas-feiras, para todos os seus benfeitores ${ }^{588}$.

A Irmandade da Senhora do Rosário dos Pardos e Pretos foi criada em 1724 e aprovada por autoridade eclesiástica em 1750. Tinha compromisso sem confirmação régia. Encomendava doze missas pelos irmãos vivos e mortos, as quais aconteciam no primeiro domingo de cada mês. As contribuições anuais eram diferenciadas, ou seja, o pagamento efetuado por cada um dos irmãos não era o mesmo. A festa da santa acontecia na segunda-feira do "oitavario da Páscoa"589.

A Irmandade de São Benedito, também "dos pardos e pretos", não tinha aprovação, nem compromisso. Também cobrava diferentes contribuições dos seus membros (anuais). A festa em louvor ao orago era realizada na segunda oitava do natal. $^{590}$

Os párocos de Iguape, além de remunerados pela Fazenda Real de São Paulo, cobravam diretamente a população e as irmandades pelos serviços religiosos oferecidos. As irmandades pagavam os párocos pela realização de missas e novenas e pela condução de festas e procissões. Por exemplo, quando o pároco realizava a Procissão dos Defuntos, era gratificado pela Confraria das Almas e, quando participava da Festa da Semana Santa, era pago pela Irmandade do Santíssimo Sacramento. Podia existir descontentamento quanto aos valores estipulados. No Regimento da Vila de Iguape, escrito em 1816, pelo vigário João Chrysostomo, consta a seguinte observação:

Pela Festa da Semana Sancta dá a Irmandade do Sanctissimo Sacram ${ }^{\text {to }}$. ao Parocho nove mil reis, pagam. ${ }^{\text {to }}$ tenuo em comparação ao grandissimo trabalho, q tem na dicta Festa, e á vista do q. ${ }^{e}$ de costume dar por ella aos mais Parochos das Igrejas deste Bispado, eq deve ser aumentada. ${ }^{591}$

Em 1824, o vigário João Chrysostomo reclamou do reduzido valor para a Irmandade do Santíssimo Sacramento e solicitou que a nova contribuição passasse a ser de 12.000 réis. O novo valor foi aceito pela irmandade.

\footnotetext{
${ }^{588}$ Livro de Tombo de Iguape (1816-1854).

${ }^{589}$ Livro de Tombo de Iguape (1816 - 1854).

${ }^{590}$ No Livro de Tombo de Iguape (1816 - 1854), a data de criação da Irmandade de São Benedito não está legível.

${ }^{591}$ Livro de Tombo de Iguape (1816 - 1854). 
No Regimento, escrito em 1816, também ficou estipulado que a Irmandade do Senhor Bom Jesus deveria pagar, anualmente, vinte mil-réis pelas missas realizadas na Igreja Matriz às sextas-feiras, a Irmandade da Padroeira deveria pagar dezesseis mil réis pelas missas realizadas aos sábados e a Confraria das Almas deveria pagar o mesmo valor pelas missas realizadas às segundas-feiras ${ }^{592}$.

Para os irmãos, era reconfortante saber que, após a morte, sua alma seria beneficiada por missas providenciadas pela irmandade que integrava. Em Iguape, assim como em outras partes do Brasil, era proveitoso participar de uma irmandade porque elas ofereciam conforto espiritual e apoio material, além de proporcionar momentos de convívio social. Os irmãos prestavam auxílio mútuo, cumprindo importantes funções assistenciais. Nesse sentido, destacava-se a importância de garantir enterro e missas aos irmãos falecidos. ${ }^{593}$

O trecho citado a seguir revela que os membros das irmandades de Iguape também tinham essa preocupação e que as irmandades procuravam atendê-la "[...] os $q^{e}$ tem possibilidade são sepultados pelas suas Irmandades" ${ }^{294}$. E os que não tinham possibilidade? Nas entrelinhas, o pároco parece afirmar que existiam pessoas que não tinham possibilidade de serem sepultadas.

Na Igreja Matriz tinha dois sacrários, um no altar maior e outro no altar do Senhor Bom Jesus. Era repartida em sepulturas, as quais integravam o patrimônio da Igreja, com exceção daquelas pertencentes às irmandades. Oito pertenciam à Irmandade do Santíssimo Sacramento - quatro localizadas acima das grades e quatro localizadas abaixo. Três sepulturas localizadas "ao pé da porta principal" foram cedidas à "[...] Irmandade da Senhora do Rozário em 1750 pelo Doutor Manuel de Jezus Pereira Vigario Capitular deste Bispado"595. O adro da Igreja Matriz, o qual abrangia "[...] toda a circunferência batizada com quatro marcos de pedra nos angulos da mesma [...]", também, servia de cemitério ${ }^{596}$. Conforme Young, os sepultamentos em volta da matriz era um "triste espectaculo", com "restos

\footnotetext{
592 Livro de Tombo de Iguape (1816 - 1854).

${ }^{593}$ Esse fato era especialmente importante para os africanos, visto o descaso com que muitos senhores tratavam os cadáveres dos seus cativos e, também, a importância que os funerais tinham nas sociedades africanas, pois representavam a passagem do mundo dos vivos para o dos ancestrais. (SOUZA, 2002, p. 184-186).

${ }_{594}^{5}$ Livro de Tombo de Iguape (1816 -1854).

${ }^{595}$ Livro de Tombo de lguape (1816 - 1854).

${ }^{596}$ Livro de Tombo de Iguape (1816 - 1854). 
dos ainda incorruptos corpos" espalhados ${ }^{597}$.

Existia uma hierarquia entre os lugares de sepultamento. Quanto mais próximo do altar, mais valorizado era o local ${ }^{598}$. Assim, comparando com as sepulturas da Irmandade do Rosário, as sepulturas da Irmandade do Santíssimo Sacramento localizavam-se em lugares mais nobres. Porém, deve-se considerar que, ao menos, a Irmandade do Rosário oferecia sepultura. Esse não era o caso da Irmandade da Padroeira Nossa Senhora das Neves, a qual, então, "[...] não dá sepultura aos seus Irmaons Fallecidos, nem manda dizer mais Missas, do que as da mencionada Capella pelos Irmãos vivos, e defunctos" $"$ "599. Diferentemente, a Irmandade de São Benedito oferecia sepultura aos irmãos falecidos, mas não fornecia tumba e nem encomendava missa. A Irmandade do Rosário fornecia sepultura e tumba aos irmãos falecidos e encomendava três missas para cada irmão morto. A Irmandade do Santíssimo Sacramento oferecia sepultura aos seus membros, inclusive às suas esposas, viúvas e filhos com até 14 anos de idade e cada irmão falecido recebia seis missas por ano ${ }^{600}$.

Em 1819, o vigário João Chrysostomo afirmou que "[...] estas irmandades são todas pobres, á excepsão da do Senhor Bom Jezus". Porém, a Irmandade do Santíssimo Sacramento parecia destacar-se frente às outras, pois oferecia maior número de missas aos irmãos falecidos e tinha sepulturas na Igreja Matriz. Caso tenha sido carente em 1819, com o decorrer dos anos, certamente, foi adquirindo um número maior de bens. Anos depois, na década de 1840, outro religioso, o vigário José Alves Carneiro, ao descrever os bens existentes na Igreja Matriz, destacou que a Irmandade do Santíssimo Sacramento possuía ricos paramentos bordados de ouro e um sino de trinta arrobas. A irmandade contou com a

\footnotetext{
${ }^{597}$ Young relatou que, no ano de 1830, um cemitério foi demarcado e foi "[...] principiado o serviço de cercal-o com muros por iniciativa do Vigario João Chrisostomo, que luctou com bastante dificuldade para começar o dito serviço por causa do preconceito arraigado no espirito do povo, que não queria que os fallecidos fossem enterrados afastados da Igreja. Por esta razão, elle não tinha o apoio do povo e por mais que fizesse, as subscripções por elle promovidas pouco produziram. (YOUNG, 1904, p. 334).

598 Os degraus do presbitério situavam-se no topo da hierarquia entre os locais de sepultamento. Assim, em 1821, quando o vigário Diogo Rodrigues faleceu, após um longo paroquiado em Iguape (1780-1820), seu corpo foi sepultado "[...] junto aos degráos do Presbitério desta Matriz com a maior pompa funebre, que se podia fazer, aque assistirão sete Sacerdotes com o Vigario Collado desta João Chrysostomo de Oliveira Salgado Bueno, e o Vigário de Cannannea Francisco de Paula Miranda Henriques". (Livro de Tombo de Iguape - 1816 - 1854).

${ }^{599}$ Livro de Tombo de Iguape (1816 - 1854).

${ }^{600}$ Livro de Tombo de Iguape (1816 - 1854). 
participação de pessoas de muito prestígio. A doação de "[...] quatro estençório, tudo de prata de lei mandada vir da Europa", feita pelo comendador João Mâncio da Silva Franco à Irmandade do Santíssimo Sacramento, sugere que o citado comendador - proprietário, muito provavelmente, da maior fortuna da região em meados do século XIX - era membro dessa irmandade ${ }^{601}$.

Ao longo do século XIX, existiu uma tendência para a formalização das irmandades. Em 1823, o bispo de São Paulo (D. Matheus) enviou provisão aos "Irmãos das Almas da Villa de Iguape", na qual confirmava os vinte e cinco capítulos do compromisso da Confraria das Almas ${ }^{602}$

Em 1842 "[...] foi criada a Irmandade do Senhor Bom Jesus com as formalidades legais" "003. O Vigário José Alves Carneiro foi nomeado procurador geral da irmandade. Na mesma década, foi criada uma nova confraria, a Irmandade da Virgem das Dores. Segundo o Vigário José Alves Carneiro:

\begin{abstract}
Nesta Parochia huma nova Irmandade da Virgem das Dores recentemente creada por instancia dos Devotos da mesma Senhora, e tem Compromisso approvado por Sua Ex ${ }^{\mathrm{a}} \mathrm{R}^{\mathrm{ma}}$ o $\mathrm{Snr}^{\circ}$ Bispo Diocesano, e pelo Ex ${ }^{\mathrm{mo}}$ Governo; os Artigos deste compromisso são bem organizados, e dá a Irmandade sepultura a seus Irmãos fallecidos, e manda dizer por cada hum delles sete Missas, e pelos Provedores quatorze, alem dos mais sufragios q' pelo mesmo he determinado. A irmandade conserva a Imagem de mesma Virgem Senhora em seu Altar ao lado da Epistola, e tem na maior veneração. ${ }^{604}$
\end{abstract}

O mesmo vigário, na mesma época, destacou que a situação da Irmandade da Padroeira tinha melhorado. Conforme o Vigário José Alves:

Tambem a Irmandade da Senhora das Neves Padroeira desta Villa, tem hoje o seu Compromisso approvado, e esta Irmandade que ate aqui tinha estado em desleixo e abandono, hoje depois do seu compromisso ista na melhor regularidade, e boa ordem, a mesma Senhora pela sua grande Proteção anime o zello dos seus Devotos Irmãos, afim deque o seu culto prospere floreça e se anime cada vez mais, como eu tanto desejo ${ }^{605}$.

\footnotetext{
601 Essa doação foi mencionada pelo Cônego Antonio Carneiro da Silva Braga, em 1890, no Livro de Tombo de Iguape (1857 - 1903).

${ }^{602}$ Provimento Aprovando Estatutos da Confraria das Almas em 21- 3-1823. Pasta de Iguape. Cúria Metropolitana de São Paulo.

${ }^{603}$ Informação relatada pelo Cônego Antonio Carneiro da Silva Braga, em 1890, no Livro de Tombo de Iguape (1857-1903)

${ }_{604}^{6}$ Livro de Tombo de Iguape (1816 - 1854).

${ }^{605}$ Livro de Tombo de Iguape (1816 - 1854).

155
} 
No século XIX, também foram edificadas capelas e uma nova Igreja Matriz. Em 1830, foi criada uma capela próxima ao rio Juquiá no lugar denominado

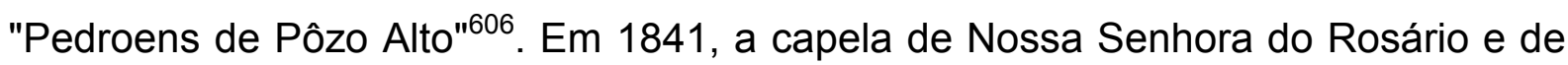
São Benedito foi fundada e, no mesmo ano, o Vigário José Alves Carneiro descreveu a história de sua edificação. O início da construção remonta ao final do século XVIII, época do paroquiado do Vigário Diogo Rodrigues da Silva (1780-1820), quando os alicerces começaram a ser levantados ${ }^{607}$. No entanto, por falta de recursos, as obras foram paralisadas. Na época do Vigário João Chrysostomo de Oliveira Salgado Bueno (1820-1833), uma pequena parte das paredes foi levantada, porém, as obras pararam novamente devido ao esgotamento dos recursos das duas irmandades, e também por causa "[...] da má administração dos Thezoureiros, Procuradores, e mais Agentes das ditas Irmandades que nem hum zello ou interesse tinhão pelo adiantamento das obras"608. Em seguida, no tempo do Vigário João Baptista Ferreira, o tesoureiro da Irmandade de Nossa Senhora do Rosário, José Antonio da Silva, preocupou-se com a continuidade das obras e, como a contribuição anual dos irmãos era reduzida, vendeu duas moradas de casas pertencentes à irmandade. Os recursos obtidos com essa venda foram utilizados para a construção de parte das paredes da capela mor e da sacristia. Porém, novamente os recursos esgotaram-se e, consequentemente, as obras foram paralisadas. Posteriormente, no tempo do Vigário José Alves Carneiro, "[...] se tornavão a animar os pretos, e sendo Thezoureiro da Irmandade de São Benedito, e Procurador Geral da Irmandade da Senhora do Rozario, João Baptista da Silva Carneiro, que movido unicamente de devoção, e zello [...]" vendeu uma morada de casas pertencente à Irmandade de São Benedito. O tesoureiro juntou os recursos dessa venda com a pequena quantia que havia nos caixas das duas irmandades e "[...] ajudado do zello, e devoção de alguns pretos Irmãos das ditas Irmandades continuo com a obra". As paredes da sacristia foram concluídas e a capela mor foi assoalhada, forrada e coberta. Assim, a capela já estava em condição de receber as

\footnotetext{
${ }^{606}$ Livro de Tombo de Iguape (1816 - 1854).

${ }^{607}$ Como "ordinariamente eram os Vigarios os encarregados da administração das obras", o tempo das obras era contado por paroquiado, ou seja, as sucessivas fases de construção da Igreja associavam-se ao respectivo vigário da época. Livro de Tombo de Iguape (1857-1903).

${ }^{608}$ Livro de Tombo de Iguape $(1816$ - 1854). 
Imagens de Nossa Senhora do Rosário e de São Benedito ${ }^{609}$.

Os irmãos das duas irmandades solicitaram ao bispo de São Paulo uma provisão de visita e benção da capela, a qual foi concedida. Dessa forma, no dia seis de março de 1841, o Vigário José Alves Carneiro visitou e benzeu a pequena igreja. No dia seguinte, foram trasladadas "[...] as ditas Imagens com hum grande concurso de Povo, e muita devoção, e Reverencia das ditas Irmandades"610. O Vigário José Alves complementou:

[...] e se Celebrou Missa tanto no dia da Benção como da trãsladação, e assim se acha servindo a dita Capella ainda que pobrissima de Paramentos, suprindo-se para a selebração das Festividades da mesma Senhora e de São Benedito com alguns Ornamentos da Matriz, mas que alguns Irmãos cheios de devoção e zello procurão ajuntar algumas esmollas, e com seus anuais pretendem ornar a sua Capella dos Paramentos necessarios, e recomendados pela Constituição do Bispado ${ }^{611}$.

A construção da nova Igreja Matriz foi ainda mais demorada e conturbada. Em 1816, o vigário João Chrysostomo afirmou que as obras para a edificação da nova Igreja Matriz tinham sido iniciadas há mais de 30 anos, portanto, no século XVIII. Ele relatou que não faltava material e nem mão de obra: "[...] o povo trabalhava de boa vontade em esquadras de vinte pessoas cada húa". No entanto, "[...] até aqui tem sido inuteis os dezejos de se levantar hua Matriz decente: e tal he a desgraça de Iguape, que podendo na sua infancia, e pobreza erigir Matriz, nos seus dias florentes não tem hum homem, que sacrifique por algum tempo os interesses pessoaes [...] " e cuide de uma obra tão necessária. Para o Vigário João Chrysostomo, ainda que os recursos fossem insuficientes, "não faltará a piedade dos fiéis" para a finalização da obra ${ }^{612}$. Em 1822, na época do seu paroquiado, as obras recomeçaram, contudo, não avançaram muito ${ }^{613}$.

Em 1838, na época do paroquiado do Vigário João Baptista Ferreira, as obras progrediram. No entanto, aconteceu um novo revés - o Vigário João Baptista faleceu e a Irmandade do Santíssimo Sacramento ficou responsável pela obra. Embora não faltasse "boa vontade e desejos de bem servir a Deus", a Irmandade utilizava

\footnotetext{
${ }^{609}$ Livro de Tombo de Iguape $(1816-1854)$.

${ }^{610}$ Livro de Tombo de Iguape (1816 - 1854).

${ }^{611}$ Livro de Tombo de Iguape (1816 - 1854).

${ }^{612}$ Livro de Tombo de lguape (1816 - 1854).

${ }^{613}$ Livro de Tombo de lguape (1857-1903). 
"imperfeitos metodos da administração e agencia de meios" e, assim, as obras não progrediram. Avanços só voltaram a acontecer em 1842, sob o paroquiado do Vigário José Alves Carneiro, quando a Irmandade do Senhor Bom Jesus foi, oficialmente criada, e esse vigário foi nomeado procurador geral da irmandade e encarregado das obras da Matriz. As obras progrediram e as paredes foram levantadas "até o ponto de receber o madeiramento". No entanto, em 1850, novo revés ocorreu. Iguape foi devastada pela febre amarela e, entre os mortos, estava o Vigário José Alves Carneiro ${ }^{614}$. A Irmandade do Senhor Bom Jesus reuniu-se para escolher um novo procurador e administrador das obras da Igreja Matriz. O escolhido para o cargo foi o Comendador Luiz Alves da Silva, um dos comerciantes mais ricos da região. Durante a sua administração, as rendas do cofre da Irmandade aumentaram e as obras progrediram até que, em 1856, foram concluídas ${ }^{615}$.

O dia oito de agosto de 1856 entrou para a história de Iguape. Nesse dia, ocorreu a festa de transladação da Imagem do Senhor Bom Jesus da velha para a nova matriz. Uma procissão de santos percorreu ruas cobertas de flores. Num cortejo, enfileiravam-se todas as Imagens que existiam na velha matriz e, por último, vinha a Imagem do Senhor Bom Jesus. Estava colocada num rico andor, carregado por oito pessoas, e acompanhada por quatro mil fiéis "[...] em cujo semblantes se nottavão o respeito e a comoção que o imponente acto os tocava". Quando o Senhor Bom Jesus atravessou "a grande alla formada das Irmandades todas", os sinos dobraram em festivos repiques e foguetes subiram ao céu. No porto, embarcações embandeiradas também participavam da festa. Aproximadamente, às 10 horas, a Imagem do Senhor Bom Jesus e os devotos entraram na nova matriz. Foram saudados pelo vigário que, em seguida, fez o sermão. A Imagem ficou exposta para a "[...] adoração que se prolongou até meia noite, tal era a Multidão de fieis que concorrera a beijar-Ihes os pés" 616 .

No dia seguinte, terminada as festividades, começaram os conflitos. "Homens proeminentes", liderados pelo Comendador Luis Alves da Silva (procurador geral da Irmandade do Senhor Bom Jesus de Iguape) defendiam que todos os santos, com

\footnotetext{
${ }^{614}$ O Vigário José Alves Carneiro nasceu em 1799 e era natural de Iguape. Em 1823, assumiu o cargo de Vigário Coadjutor de Iguape. Em 1840, com a morte do Vigário Colado João Baptista Ferreira, passou a exercer o posto.

${ }^{615}$ Livro de Tombo de Iguape (1857 - 1903).

${ }^{616}$ Livro de Tombo de Iguape (1857 - 1903). 158
} 
exceção do Senhor Bom Jesus, deveriam voltar para a antiga matriz. Esse grupo entrou em choque com o grupo liderado pelo Vigário Antonio Carneiro da Silva, que defendia a permanência de todas as Imagens.

A construção da Igreja Matriz foi um exemplo de comunhão de interesses do clero local e de uma irmandade. No entanto, num determinado momento, a aliança foi rompida, pois o clero e a irmandade passaram a concorrer pelo mesmo espaço. Como a Irmandade do Senhor Bom Jesus tinha contribuído significativamente para a finalização da construção, desejava que a nova edificação servisse de templo da irmandade, e não de Igreja Matriz. O vigário reconhecia a valiosa contribuição do Comendador Luiz Alves da Silva, no entanto, sublinhou que não podia concordar que a Irmandade do Bom Jesus se apropriasse de um bem público. Assim, conforme as palavras do vigário: "[...] não combatia por uma causa Propria. Ella era do povo que me estava confiado". Ele afirmou que não desejava sentir remorso, nem deixar um legado de discórdia para os seus sucessores e tampouco ser lembrado como "pusilãnime". 617

Nessa disputa de interesses, a questão da hierarquia entre os santos também veio à tona. Ou seja, que santo ocuparia o altar principal do novo templo? Nossa Senhora das Neves ou Senhor Bom Jesus? De fato, o Senhor Bom Jesus havia ofuscado a santa padroeira. Se, no novo templo, o altar principal fosse ocupado pelo Senhor Bom Jesus, logo, não seria a Igreja Matriz, visto a padroeira ser Nossa Senhora das Neves. Por outro lado, se o Senhor Bom Jesus não fosse colocado no altar principal, a irmandade ficaria descontente. Foi então sugerido que o Senhor Bom Jesus passasse a ser o novo padroeiro. No entanto, uma lei provincial, ao definir o nome da paróquia, garantiu lugar para os dois santos: "Paroquia da Senhora das Neves e Matriz do Bom Jesus de Iguape"618.

Os dois grupos continuavam sem se entender e até o Juiz da Comarca interferiu na questão. Ele reuniu os dois grupos para que fechassem um acordo, contudo, não obteve êxito. O Vigário Antonio Carneiro foi a São Paulo solicitar a intervenção do Bispo. Ele levou consigo vários documentos que provavam que, desde o início, a obra foi erguida para servir de Igreja Matriz: provimento do Bispo

\footnotetext{
${ }^{617}$ Livro de Tombo de Iguape (1857 - 1903).

${ }^{618}$ Livro de Tombo de Iguape (1857 - 1903). 159
} 
Dom Matheus de Abreu Pereira, Provimentos e Declarações dos Visitadores Eclesiásticos e dos Corregedores da Comarca e cópia de leis provinciais criadas entre 1838 e 1853. Essas leis destinavam recursos e criavam loterias em benefício da edificação da Igreja Matriz de Iguape. ${ }^{619}$

O Bispo de São Paulo resumiu a disputa e posicionou-se da seguinte forma:

\begin{abstract}
A Irmandade do Bom Jesus quer conciderar o novo templo como propriedade sua, isto é de B. Jesus, ficando a Ella toda a administração proxima. O Rev. Parocho Supp. concidera o novo templo como Matriz onde deve funcionar com direitos de Parocho. Tomando pois que este direito the fosse contestado, procurou segurar posse, Conquanto fosse por meio por proprios. Nos a vista dos documentos juntos conhecemos de um modo incontestavel, que o novo templo foi levantado para servir de Matriz, embora as esmolas do Bom Jesus dessem um grande ajutorio para a edificação do mesmo. Para esta Apliação houve determinação legitima: nem dôia ao povo que o novo templo servisse corelativamente a Nossa Senhora, Padroeira, e ao Senhor B. Jesus, e como tem servido a velha Matriz desde a Existencia dessa Imagem Milagrosa. Nem podemos crer que a assembleia Provincial concorresse, que se decretassem Loterias. He para um templo sem carater publico: Tudo conciderado mandamos que passe Provisão de Matriz ao novo Templo, que se levanta pia batismal, que se coloque no tabernaculo o Santissimo Sacramento, ficando o Rev. Parocho com toda a Jurisdição que nas matrizes Ihe compete. Outro Sim Mandam os que a Imagem de Nossa Senhora das Neves, Padroeira tenha um altar mor o Primeiro lugar e a do senhor Bom Jesus o Segundo. Seria de Desejar que a lllustre Irmandade, lembrando que Jesus Christo Dice $=$ Aprendei de mim que sou mando e humilde de coração $=$ abafando todo o resentimento e capricho ${ }^{620}$.
\end{abstract}

O histórico da construção da Igreja Matriz, da Capela de Nossa Senhora do Rosário e da Capela de São Benedito revelou o quanto essas edificações mais robustas representavam projetos de longo prazo. Diferentemente da segunda, que contou exclusivamente com recursos das respectivas irmandades, as obras da Igreja Matriz contaram com fontes distintas - foram beneficiadas por leis provinciais e, também, pela Irmandade do Senhor Bom Jesus. Na disputa entre o vigário e a irmandade, o primeiro saiu-se vencedor. $O$ vigário Antonio conseguiu assegurar $\mathrm{O}$ controle do novo templo e a irmandade foi criticada pelo bispo, acusada de querer apropriar-se de um bem público e de ser arrogante e vaidosa, sendo-lhe sugerido

\footnotetext{
${ }^{619}$ A lei n. 22 de 30 de Março de 1838 destinava um conto de réis; a lei n. 11 de 23 de Março de 1839, oitocentos mil réis; a lei n. 25 de 23 de março de 1841, seiscentos mil réis e a lei n. 27 de 8 de março de 1842 criou "[...] uma Loteira ao B. Jesus sendo porem seu procucto applicado na construção da nova Matriz". Outras leis foram criadas em 1844, 1846, 1850 e 1851. Em 1853, uma lei provincial determinou a cobrança de vinte réis por saco de arroz exportado por Iguape e a aplicação do montante arrecadado na construção do novo templo. Livro de Tombo de lguape (1857-1903).

${ }^{620}$ Livro de Tombo de Iguape (1857 - 1903). 
refrear a ambição.

Apesar das desaprovações, tanto o vigário quanto o bispo reconheciam a importância da irmandade e dos seus integrantes, sendo a primeira chamada de "Illustre Irmandade" pelo bispo. O vigário teve que lidar com a delicada situação de combater oponentes que respeitava. Ele sublinhou que os seus adversários pertenciam ao grupo dos "homens mais conceituados da cidade". O vigário estimava, especialmente, o Comendador Luis Alves da Silva. Afirmou admirá-lo pela sua posição social, amor à Igreja, rigidez dos costumes e honradez ${ }^{621}$.

A atitude de desafiar o vigário foi uma demonstração de força da Irmandade do Senhor Bom Jesus. Embora essa tenha sido a irmandade mais influente, outras irmandades também participaram ativamente da vida religiosa e social da localidade. Assim, do cenário esboçado pelos Livros de Tombo de Iguape (1816-1854 e 18571903), depreende-se o poder e a longevidade das irmandades e sua penetração em diferentes segmentos sociais.

O vigário João Chrysostomo supunha que a Irmandade do Santíssimo Sacramento tinha sido criada na época da formação da freguesia, ou seja, em meados do século XVI. O surgimento da Irmandade do Senhor Bom Jesus, provavelmente, remonta a meados do século XVII, "[...] epoca da collocação desta veneral Imagem nesta Matriz" ${ }^{\prime 622}$. A Irmandade de Nossa Senhora do Rosário foi criada em 1724. Dessa forma, provavelmente, existiram irmandades em lguape nos séculos XVI e XVII e, certamente, nos séculos XVIII e XIX.

Além de longevas, as irmandades envolviam grande parte da população. A maioria da população, provavelmente, fazia parte de, pelo menos, uma irmandade. A existência de muitas irmandades devia ser uma forma de atender a diferentes demandas, de grupos distintos.

Em 1819, ao se referir à Irmandade de Nossa Senhora das Neves, o padre João Chrysostomo afirmou que "todos os Cazados" faziam parte dessa irmandade. Se todos os casados pertenciam a essa irmandade e existiam outras irmandades, pelo visto, muitas pessoas participavam de mais de uma irmandade. Mais restritivas,

\footnotetext{
${ }^{621}$ Livro de Tombo de Iguape (1856-1903).

${ }^{622}$ Livro de Tombo de lguape (1816-1854).

161
} 
as irmandades do Santíssimo Sacramento e do Senhor Bom Jesus de Iguape, provavelmente, eram compostas pelas pessoas de maior poder político e econômico.

Nessa sociedade hierarquizada e escravista, negros e mestiços, assim como em outras partes do Brasil, participavam de irmandades. Como destacou Souza, a participação em uma irmandade era a forma mais clara de inserção social na América portuguesa. Isso valia não só para africanos e seus descendentes, mas era de especial interesse para eles que, assim, podiam reunir-se, festejar e lamentar com o consentimento dos senhores e das autoridades coloniais ${ }^{623}$. Em Iguape, esse segmento populacional reuniu-se em torno das irmandades de Nossa Senhora do Rosário e de São Benedito.

A partir da leitura dos Livros de Tombo de Iguape, não foi possível identificar os critérios de participação e exclusão adotados pelas Irmandades de Nossa Senhora do Rosário e São Benedito. No Brasil, muitas vezes, as irmandades formadas por negros eram constituídas por pessoas de uma mesma etnia.

Voltadas para o mesmo segmento populacional, em Iguape, as irmandades "[...] da Senhora do Rozário dos mulatos e pretos, e a de São Benedicto dos mesmos [...]" $]^{\prime 24}$ aplicaram conjuntamente seus recursos na edificação da capela e compartilharam o mesmo espaço. Então, embora se tratassem de duas irmandades, estavam atadas por um vínculo muito estreito. Quanto às diferenças, foi possível notar que a Irmandade de Nossa Senhora do Rosário era a mais antiga. A Irmandade de Nossa Senhora do Rosário foi criada em 1724. A Irmandade de São Benedito surgiu depois dessa data, mas antes de 1819. Talvez, a Irmandade de São Benedito tenha surgido de uma ramificação da Irmandade de Nossa Senhora do Rosário. Mais estruturada, esta oferecia aos irmãos falecidos sepultura, tumba e missas; enquanto aquela oferecia sepultura, mas não fornecia tumba e nem encomendava missas.

As Irmandades de Nossa Senhora do Rosário e de São Benedito desempenharam papel relevante na vida religiosa e social de Iguape. Por exemplo, numa sociedade cujos locais de sepultamento eram vistos segundo uma hierarquia,

\footnotetext{
${ }^{623}$ SOUZA, 2002, p. 186.

${ }^{624}$ Livro de Tombo de Iguape (1816-1854). 162
} 
a Irmandade de Nossa Senhora do Rosário possuía sepulturas dentro da Igreja Matriz - local mais nobre do que o adro da Igreja. Sem contar que algumas irmandades, como a da Padroeira, sequer ofereciam sepulturas.

Um claro sinal do papel destacado das Irmandades de Nossa Senhora do Rosário e de São Benedito na sociedade iguapense foi a construção de uma capela de dimensões consideráveis. Mesmo que a obra tenha durado dezenas de anos, a capacidade de arcar com os custos envolvidos numa obra dessa monta revela o poder econômico das citadas irmandades. O prestígio das duas irmandades também pode ser estimado pela grandiosidade da festa de transladação das Imagens para a nova capela, ocorrida no dia sete de março de 1841, a qual contou "[...] com hum grande concurso de Povo".

O clero interferia no funcionamento das irmandades. Pedidos de aprovação de compromisso eram submetidos à apreciação do bispo de São Paulo. Um exemplo da interferência do clero foi a doação, feita por um vigário, de sepulturas localizadas dentro da Igreja Matriz à Irmandade de Nossa Senhora do Rosário. Talvez, também interferisse na escolha dos tesoureiros e procuradores dessas irmandades. No Livro de Tombo, há um exemplo da interferência do clero no funcionamento de uma irmandade - em 1842, quando a Irmandade do Senhor Bom Jesus foi formalizada, o Vigário José Alves Carneiro foi nomeado para o cargo de procurador geral.

Além da interferência no funcionamento das irmandades, a forma como o clero lidou com o batismo demonstra seu interesse na inclusão de africanos e seus descendentes no mundo cristão. Em 1816, no Regimento da Paróquia de Iguape, redigido pelo vigário João Chrysostomo, foi estipulado que o pároco receberia os valores de trezentos e vinte réis, com o acréscimo de, no mínimo, oitenta réis da madrinha e oitenta réis do padrinho, pelo batismo de pessoa branca ou livre; cento e sessenta réis, mais oferta de, no mínimo oitenta réis da madrinha e oitenta réis do padrinho, pelo batismo de escravizados; e seiscentos e quarenta réis, mais ofertas, pelo batismo de adultos. Nessa última categoria, encontravam-se os africanos adultos, pois brancos e escravizados nascidos no Brasil eram batizados em tenra idade. O vigário explicou que o valor era mais elevado para essa última categoria porque o batismo de africanos adultos demandava uma quantidade maior de 
trabalho. Assim, parece que o clero de lguape transmitia aos africanos adultos alguns fundamentos da doutrina cristã antes de administrar o sacramento do batismo. Abaixo, o trecho do Livro de Tombo que aborda essa questão:

De cada Baptizado de pessoa branca ou livre tem o Parocho hûa vella de meia libra ou trezentos e vinte reis e as offertas, q. ${ }^{e}$ nunca devem ser menos de oitenta reis pelo Padrinho e o mesmo pela Madrinha de cada Baptizado de escravo tem hûa vella de quarta, ou cento e secenta reis, e as mesmas offertas: eisto ainda mesmo $\mathrm{q} .{ }^{\text {do }}$ por necessidade haja sido baptizada em caza, e venha á Igreja p. ${ }^{a}$ se lhe pôr somente os Santos Oleos, Costuma dar-se por cada Baptizado de Adultos, ordinariam. ${ }^{\text {te }}$ escravos Neophitos, ou buçais que vem da Costa de Guiné seiscentos equarenta reis de Vella, e offerta; por isso mesmo dão m. ${ }^{\text {to }}$ mais trabalho q. ${ }^{\mathrm{E}}$ os outros baptizados ${ }^{625}$.

Numa outra passagem do Livro de Tombo, o vigário João Chysostomo ressaltou a necessidade de os cativos recém-chegados da África receberem ensinamentos religiosos. Ao descrever a população de Iguape, o vigário relatou que havia mais de cem cativos "[...] neophitos, chamados buçais, vindos da costa d'África, os quaes por não terem a necessaria instrução da Doutrina Christã não tem sido ainda admittidos aos Sacramentos da Igreja"626.

O trecho acima demonstra que, caso os africanos tenham tido contato com os ensinamentos cristãos na África, isso não era reconhecido pelo clero de Iguape. Além disso, o trecho citado aponta novamente para a preocupação do clero em transmitir aos africanos os fundamentos da doutrina católica e, assim, admiti-los no mundo cristão. Para o clero, essa inclusão garantia o controle no campo espiritual e também vantagens no campo econômico, pois os africanos passariam a demandar e, consequentemente, a pagar por serviços religiosos. Para os senhores, a inclusão dos africanos no mundo cristão também era vista como positiva, pois o pertencimento dos cativos ao mesmo universo cultural dos senhores facilitava o controle. Para os africanos, a inclusão era igualmente benéfica, pois ampliava os lugares permitidos e as interações sociais. Por exemplo, a inclusão no mundo cristão dava acesso a festas e procissões e possibilitava a participação em uma irmandade religiosa.

Africanos e seus descendentes participavam de "irmandades de homens

\footnotetext{
${ }^{625}$ Livro de Tombo de Iguape $(1816-1854)$.

${ }^{626}$ Livro de Tombo de Iguape $(1816-1854)$.

164
} 
pretos", assim como essas irmandades participavam de um mundo religioso protagonizado por irmandades. Isso significava que africanos e seus descendentes estavam incluídos na sociedade. Porém, em uma sociedade hierarquizada e escravista que ao mesmo tempo em que admirava as festas promovidas pelas irmandades de Nossa Senhora do Rosário e de São Benedito, testemunhava a tortura de cativos realizada num pelourinho erguido no pátio da Igreja Matriz.

Em 1833, os vereadores da Câmara externaram o seu descontentamento com a presença do pelourinho. Durante uma sessão da Câmara, no dia quinze de janeiro de 1833, os gritos de dor proferidos por um escravizado paralisaram o trabalho dos vereadores. O presidente da Câmara propôs que um novo pelourinho fosse erguido em uma nova localidade. Segundo a ata da Câmara:

\begin{abstract}
Forão interrompidos os trabalhos da Camara pelos gritos dolorosos de hum infeliz preto, sobre quem pezava o castigo. Nesta occazião o Senhor Presidente propoz de remover o lugar onde devem ser castigados os Captivos, para o fim de evitar o escandalo; visto que esta execução se pratica no meio da Villa, e no lugar o mais publico della, habitado de familias muito de bem e honestas ${ }^{627}$.
\end{abstract}

Os gritos do escravizados foram capazes de interromper a sessão da Câmara, portanto, os vereadores não eram indiferentes à violência praticada no pelourinho. No entanto, o que incomodava não era a violência em si, mas onde ela estava sendo praticada - no pátio da Igreja Matriz, ao pé da Câmara, ou seja, no centro do poder da vila e onde habitavam as famílias de maior prestígio social.

Talvez, a lguape do século XIX sofresse influência das idéias iluministas críticas em relação à escravidão e à violência praticada contra os escravizados. Talvez, os vereadores de Iguape sentissem o descompasso entre o que praticavam e as idéias vindas do exterior acerca de "civilidade". Dessa forma, eles sentiam-se embaraçados com a presença do pelourinho no "lugar mais publico" da vila, portanto, mais visível. A localização do pelourinho também foi definida como um "escandalo", ou seja, algo execrável que vem a público. Portanto, pode-se afirmar que o desconforto não era causado pela violência contra os escravizados, mas pela visibilidade dessa violência.

${ }^{627}$ Ata da Sessão da Câmara do dia 15 de janeiro de 1833 (apud YOUNG, 1904, p. 362 - 363). 165 
Os vereadores de lguape podiam sentir-se constrangidos com a presença do pelourinho, mas não a ponto de abrir mão desse instrumento de coação. Ou seja, idéias iluministas podem ter sido consideradas, mas não poderiam ameaçar os interesses vigentes. A solução encontrada foi a mudança da localização do pelourinho. Relacionada a essa contradição, existia outra: o local não podia ser o mais visível da vila, mas tinha que ter certa visibilidade porque o castigo ali executado era exemplar e devia ser visto pelo público. Um dos vereadores lembrou que o local preferido pelos escravizados para se reunirem era o "alto da fonte" e sugeriu que o novo pelourinho fosse erguido nessa localidade. Conforme a ata:

\begin{abstract}
Nesta mesma occazião o Senhor Veredor Satyro lembrou o alto denominado da fonte, como o mais appropriado, visto que este castigo he só dirigido aos pretos, e ali ser o lugar onde elles mais se juntão, e onde se combinão para algûas disordens que têm aparecido nesta classe de gente, e ao mesmo tempo que nada soffre a Moral Publica ${ }^{628}$.
\end{abstract}

Aos olhos do vereador Satyro, o local sugerido era o ideal porque era onde os escravizados se reuniam para combinar "algûas disordens", ou seja, era uma forma de punir delitos onde eles estavam sendo planejados. Também era o principal ponto de encontro dos escravizados. E era isso que importava, pois só eles eram punidos dessa forma ("visto que este castigo he só dirigido aos pretos"). O local não era retirado, era próximo do núcleo do poder, mas não era no meio do núcleo do poder, ao lado da Câmara e da Igreja. O novo local não era o lugar mais visível da vila, mas era bastante visível para os escravizados.

Por unanimidade, a proposta foi aceita. O antigo pelourinho foi removido e "[...] hum poste quadrado, em que lhe mande por dois Argoloins de ferro [...]", foi erguido no alto da fonte. A Câmara concluiu que, com a nova localização do pelourinho, "nada soffre a Moral Publica". Portanto, num cenário marcado por tensas relações sociais, a "Moral Publica" da Iguape escravista determinava que a violência contra os escravizados deveria ser visível, mas nem tanto.

Young comentou essa ata da Câmara. Ele viveu em Iguape no final do século XIX e começo do XX, ou seja, logo após a abolição. A lembrança da escravidão

${ }^{628}$ Ata da Sessão da Câmara do dia 15 de janeiro de 1833 apud YOUNG, 1904, p. 362 - 363. 166 
ainda estava presente. Podemos perceber que, para o inglês Young (membro da elite intelectual de Iguape, sócio do Instituto Histórico e Geográfico de São Paulo), a noção da incompatibilidade entre uma sociedade civilizada e a escravidão, com o pelourinho sendo seu maior exemplo ("symbolo dos tempos barbaros"), estava bastante consolidada. Conforme Young:

O antigo costume de punir certos crimes, expondo os criminosos no Pelourinho e castingo-os publicamente, conservou-se aqui até pouco tempo passado. Ha muitas pessoas que me affirmam terem visto ao pé do antigo chafariz, existente no Largo da Misericordia, este symbolo dos tempos barbaros, com entes humanos seguros a elle durante dias e noites, sofrendo assim as maiores torturas. A ultima noticia que encontrei em documento é do anno de 1833 e prova que até aquella data o logar do castigo era ao pé da casa da Camara, no pateo da Igreja, sendo mudado neste anno ao logar indicado por pessoas existentes ${ }^{629}$.

${ }^{629}$ YOUNG, 1904, p. 362. 


\subsection{Igrejas e Irmandades de Xiririca}

Devido ao laço existente entre Xiririca e Iguape, há referência à Freguesia de Xiririca no Livro de Tombo de Iguape e à Vila de Iguape no Livro de Tombo de Xiririca. Conforme relatado no Livro de Tombo de Iguape, Xiririca, nos primeiros tempos, recebia a visita dos párocos de Iguape apenas uma vez por ano. $\mathrm{Na}$ ocasião, as pessoas se confessavam e recebiam os sacramentos, como a eucaristia, o batismo, o casamento e a extrema-unção ${ }^{630}$. Essa informação também está presente no Livro de Tombo de Xiririca, no entanto, o pároco da localidade adotou um tom mais crítico. Ele enfatizou que Xiririca era filial da Igreja Matriz de Iguape, "[...] cujo Parocho Ihes administrava os Sacramentos como Seus Paroquianos, mas que pela grande distancia, em que se-achavão, apenas erão Soccorridos com o pasto espiritual de anno á anno pelas Desobrigas da quaresma, de que tinha resultado morreram muitos sem Sacramentos"631.

Insatisfeitos com essa situação, os moradores de Xiririca erigiram uma capela nas margens do rio Xiririca, sob invocação de Nossa Senhora da Guia. Eles solicitaram ao bispo de São Paulo o desmembramento da Igreja Matriz de Iguape. Em 1763, o bispo atendeu ao pedido. Além disso, a capela foi elevada a freguesia, passando a ser chamada de Freguesia de Nossa Senhora da Guia de Xiririca ${ }^{632}$.

A criação da freguesia deveria corresponder à intensificação dos serviços religiosos oferecidos pelo clero. O Livro de Tombo de Xiririca informa o número de casamentos e batizados realizados pelos párocos de Xiririca entre os anos da criação da freguesia (1763) e do décimo terceiro ano do paroquiado do Reverendo Joze Francisco Mendonça (1819). O batismo, principal sacramento realizado, cresceu acentuadamente ao longo desses anos. O primeiro pároco da Freguesia, Reverendo Joze Martins Tinoco (1763 - 1773), realizou 186 batizados; o Reverendo Antonio Pedrozo de Barros Leite (1773 - 1775) realizou 77 batizados; o Reverendo João Teixeira da Cruz (1775 - 1780), 136 batizados; o Reverendo Antonio Pedrozo de Barros Leite, que assumiu novamente o posto em 1780 e permaneceu até 1798,

\footnotetext{
${ }^{630}$ Livro de Tombo de Iguape (1816-1854).

${ }^{631}$ Livro de Tombo de Xiririca (1816-1898).

${ }^{632}$ Livro de Tombo de Xiririca (1816-1898). 168
} 
realizou 501 batizados; o Reverendo Xavier de Passos (1798 - 1806), 426 batizados; o Reverendo Joze Francisco de Mendonça (1806 - 1819), 1103 batizados. Ou seja, mesmo que o número de pessoas da freguesia tenha aumentado, certamente o número de pessoas batizadas cresceu numa proporção muito maior. Isso fica mais claro se compararmos os 10 anos de trabalho do primeiro pároco, quando foram batizadas 186 pessoas, com os 13 anos do Reverendo Joze Francisco, quando foram batizadas 1103 pessoas. A freguesia, seguramente, não cresceu nessa proporção.

Uma das dúvidas levantada é se a população negra de Xiririca estava incluída no cômputo do número de batizandos. Embora não exista essa informação, os dados relacionados aos casamentos oferecem a pista. Do total de casamentos realizados, os negros constituíram percentual bastante expressivo. Se o clero preocupou-se em realizar casamentos entre os negros, certamente preocupou-se em batizá-los. Portanto, os negros eram foco da atenção do clero.

Os números relacionados aos casamentos não são dados claramente. Os párocos informaram o número total de casamentos e o número de casamentos entre a população branca. No entanto, podemos estimar o número de casamentos entre os negros se subtrairmos o número de casamentos da população branca do número total de casamentos realizados. A população indígena não parece fazer parte dos cálculos. Na única anotação completa, referente ao primeiro paroquiado do Reverendo Antonio Pedrozo de Barros Leite (1773-1775), apenas brancos, pardos e pretos se casaram. Nesse período, foram realizados 10 casamentos, seis de brancos e quatro de "pardos e pretos". Quanto aos demais párocos, temos estes dados: o Reverendo Jozé Martins Tinoco (1763-1773) realizou 39 casamentos, sendo 12 de pessoas brancas; o Reverendo João Teixeira da Cruz (1775-1780) realizou 9 casamentos, "dous sómente de pessoas brancas"; o Reverendo Antonio Pedrozo de Barros Leite, no seu segundo paroquiado (1780-1798), 84 casamentos, 52 de brancos; o Reverendo Francisco Xavier de Passos (1798 - 1806), 72 casamentos, 41 de "pessoas havidas por brancas" e o Reverendo Joze Francisco de Mendonça (1806-1819), 229 casamentos, 82 de pessoas "havidas por brancas".

Os dados apresentam muitas lacunas - não informam, claramente, os segmentos populacionais que contraíram matrimônio e não abordam a questão dos 169 
casamentos entre etnias distintas. O segmento "pessoas havidas por brancas" mencionado pelos Reverendos Francisco Xavier de Passos e Joze Francisco de Mendonça também dão margem à dúvida. De qualquer forma, os dados sugerem, fortemente, que grande parte dos casamentos realizados pelo clero envolveu a população negra. Entre as muitas observações que poderiam ser feitas, destacamos a pequena importância do casamento no paroquiado do Reverendo João Teixeira da Cruz (1775-1780), quando foram realizados, em cinco anos, apenas nove casamentos, e o pequeno percentual de brancos envolvidos (apenas dois casamentos de brancos). No paroquiado do Reverendo Joze Francisco de Mendonça (1806-1819), cresceu bastante o número de casamentos (229) e, como apenas 82 eram de pessoas "havidas por brancas", certamente, grande parte dos casamentos foi realizado entre negros.

A preocupação do clero com a inclusão dos negros no mundo cristão também pode ser inferida pelo fato dos serviços religiosos serem direcionados aos escravizados. A partir da leitura da tabela de preço desses serviços, podemos constatar que o mesmo serviço era oferecido tanto para brancos e libertos quanto para cativos, no entanto, em alguns casos, havia diferença de preço. Em 1816, o Reverendo Joze Francisco de Mendonça sublinhou que escravizados e livres pagavam o mesmo valor pelo batismo. Observou que nas igrejas "mais bem reguladas", os valores eram diferenciados. Assim, o Reverendo Visitador de Paranaguá determinou que fossem adotados os seguintes valores: os escravizados deveriam pagar um quarto de cera, enquanto os brancos e libertos, meia libra de cera. Nos enterros, o vigário deveria receber meia libra de cera dos brancos e libertos e um quarto de cera dos escravizados. Em vários serviços religiosos, os valores eram diferenciados. Em alguns serviços, parece que não havia diferenciação. De qualquer forma, como os escravizados eram citados na lista dos serviços religiosos oferecidos, certamente, eram alvo da preocupação do clero ${ }^{633}$.

Os negros organizavam festejos em louvor aos santos católicos. São Benedito era a "Devoção mais antiga dos Pretos e Pardos desta Freguezia". O santo era homenageado "pelas Oitavas do Natal do Senhor"634. Nossa Senhora do Rosário, também, era homenageada. A festa ocorria na época da quaresma, quando

\footnotetext{
${ }^{633}$ Livro de Tombo de Xiririca $(1816-1898)$.

${ }^{634}$ Livro de Tombo de Xiririca $(1816$ - 1898).

170
} 
os negros eram obrigados a participar da desobriga quaresmal na sede da freguesia. Conforme o Livro de Tombo de Xiririca:

\begin{abstract}
Visto que a maior escravatura teve o seu princípio e aumento no Arraial de Ivaporunduva, e os pretos daquele bairro é que começaram a festejar a senhora do Rosário, é igualmente constante que aquele pretos mandarás vir a sua custa a imagem de Nossa Senhora do Rosário, e com as suas esmolas fizeram o primeiro altar na Primeira Igreja Matriz.

Matriz anterior a esta, e porque o tempo que tinha mais oportuno era o da Paschoa da Ressurreição, quando desciam para se desobrigarem dos preceitos da quaresma, por essa razão festejaram tão bem nesse tempo, a Nossa Senhora do Rosário, donde ficou o costume que até hoje é guardado da mencionada festividade pela Paschoa, fazendo-se eleição dos juizados entre os pretos, que se encorporão como debaixo de uma irmandade. ${ }^{635}$
\end{abstract}

Os festejos em louvor à santa eram organizados por uma irmandade não formalizada. Podemos deduzir isso pela descrição realizada, "[...] os pretos, que se encorporão como debaixo de uma irmandade". O trecho do Livro de Tombo, que descreve os bens dessa irmandade, também reforça essa hipótese. Entre outros bens, possuíam "[...] uma caixa pequena com três fechaduras, que é o cofre das esmolas e papel da Irmandade como Ihe chamão"636.

Outros santos também eram festejados na freguesia de Xiririca: Nossa Senhora da Guia, São João Baptista e Santo Antonio de Lisboa. E também o Espírito Santo ${ }^{637}$. No entanto, assim como na Vila de Iguape, era Nossa Senhora do Rosário e São Benedito que estavam associados à população negra.

No Brasil Colonial, a invocação mais frequente das "irmandades de homens pretos" foi a Nossa Senhora do Rosário. Essa devoção foi estimulada pela Igreja na sequência do Concílio de Trento. Assim, foram estabelecidas irmandades sob invocação de Nossa Senhora dos Rosário nas variadas partes do Império português - Brasil, África e Portugal. Conforme Santos:

Transformada em um dos grandes baluartes da reforma de Trento, a Virgem Maria incrustou-se na piedade popular lusa e serviu de esteio à evangelização dos povos colonizados pela Coroa. No continente africano e na América portuguesa, tal como na metrópole, cativos ou libertos, oriundos da África Central ou descendentes de nativos desta região, reuniram-se em

\footnotetext{
${ }^{635}$ Livro de Tombo de Xiririca $(1816-1898)$.

${ }^{636}$ Livro de Tombo de Xiririca $(1816$ - 1898).

${ }^{637}$ Além desses santos, os moradores de Xiririca aguardavam a chegada da Imagem das Dores de Maria Santíssima para a introdução dessa devoção na freguesia. Livro de Tombo de Xiririca (1816 1898). 
irmandades sob a proteção de Nossa Senhora do Rosário ${ }^{638}$.

Marina de Mello e Souza, baseando-se em Serafim Leite, afirmou que já em 1586 os jesuítas instituíram irmandades de Nossa Senhora do Rosário para promover a piedade e a instrução religiosa de negros e indígenas ${ }^{639}$. São Benedito, Santa Ifigênia e Santo Elesbão também foram oragos bastante frequentes de "irmandades de homens pretos" na América portuguesa.

Em Xiririca, a festa em louvor a Nossa Senhora do Rosário era um momento importante para os habitantes de Xiririca porque representava uma oportunidade de contato social. O primeiro pároco, Reverendo Jozé Martins Tinoco (1763-1773), enfatizou o aspecto solitário da freguesia. O Reverendo Antonio Pedrosozo de Barros Leite (1780-1798) sublinhou que, num tempo anterior ao seu paroquiado, as interações sociais eram ainda mais esporádicas. Conforme esse pároco: "Era emtão ainda esta Freguezia mais remota, mais solitaria e triste, que não o he presentemente, e porisso capáz de encher os animos de afflicção, quando se-sente demais a mais a falta da Sociedade, do Comercio, e da frequencia humana" ${ }^{640}$.

Além de promover a festa anual em louvor ao orago, os negros da Irmandade de Nossa Senhora do Rosário dos Homens Pretos custearam a construção de um altar na Igreja Matriz dedicado à santa, uma estátua de madeira que "[...] mandarão vir da Cidade de $S^{m}$ Paulo" e uma capela em Ivaporunduva ${ }^{641}$. O patrimônio da irmandade era formado por uma morada de casas (vizinha à capela), uma "sorte de lavras" (doada por um dos mineiros de Ivaporunduva), móveis e alfaias. Segundo o pároco de Xiririca: "He igualmente que se sabe sahir do trabalho dos Pretos o dinhro. com que se comprarão os primeiros moveis e Alfayas, assí como sahio para a Obra da Capella e seu Patrimonio referidos"642. Num outro trecho, o pároco destacou que os proprietários de cativos incentivaram a construção da capela de Ivaporunduva, contudo, reforçou que os recursos eram provenientes dos negros. Conforme o Livro de Tombo de Xiririca:

\footnotetext{
${ }^{638}$ SANTOS, Georgina Silva dos. Devoções Atlânticas: A construção da identidade social e religiosa de cativos e libertos na Bahia Colonial. Afro-Asia, n. 46, 303-310.

${ }_{639}$ SOUZA, 2002, p. 186 e 207.

${ }^{640}$ Livro de Tombo de Xiririca $(1816-1898)$.

${ }^{641}$ Livro de Tombo de Xiririca $(1816-1898)$.

${ }^{642}$ Livro de Tombo de Xiririca $(1816$ - 1898). 
Concorrendo pois os senhores dos sobreditos escravos com a sua aprovação e auxílio, mormente o Capitão Joaquim Machado de Moraes, de quem já falamos, erigiu-se debaixo da Faculdade ordinária a referida capela, no lugar em que existe, pagando-se todo trabalho dos taipeiros e carpinteiros com o ouro dos mesmos escravos ${ }^{643}$.

Mesmo antes da edificação da capela, o bispo de São Paulo já tinha autorizado a administração dos sacramentos em Ivaporunduva. Os moradores de Ivaporunduva relataram ao bispo os problemas decorrentes da obrigatoriedade da desobriga quaresmal ser na Igreja Matriz de Xiririca. Eles relataram os prejuízos econômicos advindos do afastamento dos escravizados do trabalho e temiam que esse afastamento pudesse ser ainda maior caso o Rio Ribeira enchesse. Além disso, como os escravizados também se dedicavam à lavoura de subsistência, haveria o risco de as pessoas da localidade passarem fome. As desventuras ocorridas durante o trajeto pelo Rio Ribeira, como afogamentos e perdas da carga, também foram enfatizadas. Solicitaram ao bispo que a desobriga da quaresma e o batismo fossem realizados no próprio bairro. Mais uma vez, era ressaltado o papel central do batismo. Abaixo, o trecho do Livro de Tombo de Xiririca que aborda essa questão:

\begin{abstract}
Muito Reverendo Senhor Doutor Vigário Capitular. Dizem os moradores das Minas de Ivaporunduva, Freguesia de Nossa Senhora da Guia de Xiririca, que o seu Reverendo Parocho os obriga no tempo da quaresma dar satisfação aos preceitos anuais na capela da Freguesia, de que se segue aos suplicantes intoleravel danos nas suas fazendas pelos muitos dias, que perdem no trabalho de seus escravos, acontecendo as vezes ficarem ilhados pelos contratempos de uma caudalosa ribeira, pela qual descem e sobem, passando falta de mantimentos, e muito mais pelos visto das canoas carregadas de gente de toda a idade, de que sucedem infortunios, como pouco tempo há pela mesma ocasião, se afogou uma escrava, e mais tres que correram grande perigo, perdendo tudo, e de proximo tres pessoas affogadas, uma pagem, e o mesmo acontece aos daquela paragem, quando se vem Baptizar, e outros muito incovenientes não menos temerosos, que por notorio se não allegas. Portanto, pedem a Vossa Senhoria, attendendo ao referido inconveniente, conceda benignamente se possão desobrigar na dita paragem, e que o Reverendo Parocho, achando-se nella possa batizar todas aquelas crianças, que nesse tempo se lhe oferecem, para se evitarem os mencionados inconvenientes. E receberão mercê [...] O Reverendo Parocho os podera desobrigar, e administrar-lhes os mais sacramentos necessarios na paragem referida, e lugar que para esse efeito se prepara com a decencia que for possivel. São Paulo, $1^{\circ}$ de março de 1770.
\end{abstract}

Entre os muitos moradores do arraial de Ivaporunduva citados pelo pároco de

${ }^{643}$ Livro de Tombo de Xiririca (1816 - 1898).

173 
Xiririca, alguns pareciam próximos do clero e preocupados com a evangelização dos cativos. Por exemplo, o já citado Capitão Joaquim Machado de Moraes foi "[...] possuidor de muitos escravos, e algúas lavras no menciona(o) array d'Ivaporundyva. Auxiliou muito a construção da Capela de Nossa Senhora do Rosario dos Pretos de Yvaporundyva". Domingos Rodrigues Cunha "[...] foi igualmente possuidor de escravos; e o Reverendo Antonio Pedrozo de Barros Leite o-honrou com a sua Amizade". Porém, o nome mais enaltecido foi o de Joana Maria. Conforme o pároco:

\begin{abstract}
Mas com justa razão ainda mais memoravel o Nome de Joana Maria, natural das Minas Geraes, não pela nobreza de seu sangue, ou por deixar muitos filhos, ou enfim pelas suas riquezas, nada de tudo isso ella os teve, ou fez a satisfação dos seus desejos. Toda a sua distincção lhe proveio unicamente das suas honestas e virtuosas acçoens enobrecidas pela sua admiravel caridade ${ }^{644}$.
\end{abstract}

Joana Maria chegou ao arraial de Ivaporunduva casada com o português André de Souza. Após a morte do primeiro marido, casou-se com o português João Marinho. Novamente viúva, casou-se com João Manuel de Siqueira Lima, natural de Minas Gerais. Antes da edificação da capela de Nossa Senhora do Rosário dos Homens Pretos, era na casa de Joana Maria que os sacramentos, com exceção do matrimônio, eram administrados. Conforme o Livro de Tombo:

Tendo vinda para este arrayal casada com André de Souza, oriundo de Portugal, bem se pode affirmar q' ella foi a Alma o melhor uso dos bens que a Providencia confiou as suas maons. Por fallecimento do primeiro Marido tornou a cazar com João Marinho, tãobem de Portugal, e por morte deste terceira vez com João Manuel de Siqueira Lima, natural das Minas Geráes, talvez alliciados todos das estimaveis qualidades desta Piedosa Mulher, cuja casa em todo o tempo foi o abrigo dos Pobres, o Hospicio dos Peregrinos, e o que hé mais, honrada no espaço de vinte e dous annos, mais ou menos, como a de Martha e Maria, pela Presença Real de Jesus Christo, pois nella se-celebrava o S.to Sacrificio, ao que parece antes de Servir a Capella de Nossa Senhora do Rosario dos Pretos, por eleição bem acertada o Primeiro Parocho Joze Martins Tinoco no anno Septimo do seu Parochiato $^{645}$.

O clero desejava a edificação da capela para reforçar sua presença na localidade. Assim, em resposta às "exhortaçoens saudaveis" do pároco João Teixeira da Cruz (1775-1780), "[...] se-deliberarão os escravos e Moradores de Yvaporúdyva erigiar a Capella de Nossa Senhora do Rosario dos Pretos d'aquelle bairro". Dificuldades surgiram durante o período de edificação, contudo, por fim, as

\footnotetext{
${ }^{644}$ Livro de Tombo de Xiririca (1816 - 1898).

${ }^{645}$ Livro de Tombo de Xiririca - 1816 - 1898.

174
} 
obras terminaram. No dia 21 de agosto de 1791 o Reverendo Antonio Pedrozo de Barros Leite benzeu a capela e demarcou o adro. Assim, os sacramentos deixaram de ser realizados na casa de Joana Maria. O Vigário Joze Francisco Mendonça fez o seguinte comentário acerca da construção da capela:

\begin{abstract}
Não consta o tempo certo em que teve princípio esta obra, mas sem dúvida que foi dentro dos cinco anos do parochiato do reverendo João Teixeira da Cruz, entre 1775 e o anos de 1780 , de quem adiante falaremos. O qual reverendo Parocho, persuadido da necessidade e utilidade desta capela naquele bairro, moveu ainda mais os sobreditos moradores e seus escravos a porem em execução os seus louváveis desejo. A não pequena demora com tudo, que padeceu até a sua dedicação ou benção, acima mencionada, deixa ver que algumas dificuldades, como acontece em semelhantes obras, retardaram o uso desta Capela, que apenas ficou concluída no que toca somente ao corpo da igreja, sem terem podido levar a fim a sua capela mor, e a sua pequena sacristia ${ }^{646}$.
\end{abstract}

O término da capela parece ter coincidido com o período de declínio da mineração. O arraial minerador foi extinto e uma nova dinâmica populacional emergiu. Muitos ex-mineradores partiram; outros, empobrecidos, alforriaram ou abandonaram seus cativos; e ainda outros alocaram recursos (terras e cativos) na atividade econômica que despontava na região - o cultivo de arroz. Assim, na região de Ivaporunduva, passaram a coexistir propriedades com escravizados e núcleos de negros libertos.

É possível saber o destino dos cativos de Joana Maria. Ao longo da vida, Joana Maria foi alforriando seus escravizados. Segundo os Maços de População de Xiririca, em 1801, Joana Maria vivia com 18 agregados - todos pretos - e 2 escravizados. Como ela era uma antiga proprietária de cativos (detentora da terceira maior posse de Ivaporunduva), certamente, esses agregados eram seus ex-cativos. Conforme o pároco de Xiririca, um ano depois, "Falleceu emfim esta virtuosa Mulher aos 2 de Abril de 1802, com idade de noventa annos, sem deixar bens alguns porque em vida soube distribuil-os, remunerar com a liberdade os escravos que the servião"647.

A atitude de alforriar os ex-cativos talvez fosse consequência de um sentimento de identidade com os mesmos, pois Joana Maria era mestiça. De acordo

\footnotetext{
${ }^{646}$ Livro de Tombo de Xiririca - 1816 - 1898.

${ }^{647}$ Livro de Tombo de Xiririca $(1816$ - 1898).

175
} 
com Agnaldo Valentim, nos Maços de População de Xiririca de 1801, Joana Maria aparece como natural de Mariana, parda e viúva ${ }^{648}$. O pároco de Xiririca também destacou que ela seria lembrada pelas suas virtudes e não pela "nobreza de seu sangue". E, de fato, Joana Maria não foi esquecida. Nos dias atuais, seu nome ainda é lembrado na região de Ivaporunduva. As alforrias contribuíram para o seu prestígio. Seu esforço em prol da difusão do catolicismo - seja oferecendo sua casa para a realização do sacramento, seja apoiando o clero e a Irmandade de Nossa Senhora do Rosário dos Homens Pretos - também deve ter contribuído para a notoriedade do seu nome.

Na região do Médio Ribeira, no final do século XVIII e no começo do século XIX, alguns senhores, uma Irmandade sob invocação de Nossa Senhora do Rosário e uma capela filial da Igreja Matriz de Xiririca atuavam em prol da cristianização dos povos. A capela recebia a visita do pároco, o qual oferecia serviços religiosos, como missa e batismo. No entanto, essas visitas deviam ser ocasionais. No começo do século XIX, o Reverendo Visitador de Paranaguá (Rev. Leâl) relatou ao bispo de São Paulo o isolamento da Igreja de Xiririca e da capela de Ivaporunduva em relação à Vila de Iguape. Ele sublinhou os riscos envolvidos na viagem pelo Ribeira entre esses três pontos - Iguape, a sede de Xiririca e a capela de Ivaporunduva. Ele acreditava que o receio de viajar pelo Rio Ribeira tenha feito com que a freguesia de Xiririca ficasse trinta e sete anos sem receber a visita de um Reverendo Visitador de Paranaguá. O Rev. Leâl solicitou ao bispo de São Paulo que a Freguesia de Xiririca tivesse vara própria, separada da Vara de Iguape, e que o vigário Joze Francisco de Mendonça se tornasse Vigário da Vara, com autonomia para nomear escrivão e promotor. Além das distâncias e dos perigos decorrentes da viagem pelo Rio Ribeira, o parentesco entre o vigário de Xiririca (Joze Francisco Mendonça) e o bispo de São Paulo (Matheus Abreu Pereira) também foi destacado. Segundo o Livro de Tombo de Xiririca:

Excellentissimo e Reverendissimo Senhor. Com o mais profundo respeito representa o R. Joaquim Julio da Resurreição Leal, Visitador que acaba das duas Comarcas da marinha, que indo visitar a Igreja da Senhora da Guia de Xiririca, achou ser tão distante aquella Parochia da Villa de Iguape para o recurso da Vara, que merece ser desmembrada, creando ao Muito

\footnotetext{
${ }^{648}$ VALENTIN, Agnaldo. Uma civilização do arroz: agricultura, comércio e subsistência no Vale do Ribeira (1800-1880). 2006. Tese (Doutorado em História Econômica) - Faculdade de Filosofia, Letras e Ciências Humanas da Universidade de São Paulo, São Paulo, 2006, p. 133. 
Reverendo Vigario Jozé Francisco de Mendonça em Vigario da Vara de Xiririca: desta Freguezia se-gastão dous dias ribeira abaixo á Villa de Iguape, e para desta tornar á Xiririca, se gastá ribeira ásima cinco dias por entre cachoeiras; e de Yvapurúdyba Capella Filial de Xiririca, para se alcançar algum despacho ou Provisão da Vara, se gastão certamente Sette ou oito dias. E que coisa, Excelentíssimo Senhor, tão custosa áquellas desvalidas Ovelhas, para alcançar o remedio de Suas consciencias! Talvez que esta tão grande distancia seja a causa dos reverendos Visitadores á trinta e Sette annos não visitarem aquella Freguezia de Xiririca, temendo as cheias da Ribeira, que são tão caudalosas, que por alguns dias fica interceptado o commercio com o da Villa d'Iguape. Estas tão ponderosas, e attendiveis circunstancias unidas ao conhecimento, que tem $0 \mathrm{R}$. representante, de que nemhua coisa occupa com mais desvelo o terno coração de Vossa Excellencia Reverendissima, doq' Socorrer com prontidão as Suas Ovelhas, e as Suas necessidades, espéra $q^{\prime} V$. Ex ${ }^{a} R^{a}$ nomêe ao $d^{\circ}$ M. R. Jozé Francisco de Mendonça em Vigario da Vara de Xiririca, dandoIhe poder para elle nomear Promotor e Escrivão idóneo, para Se-Ihe mandar Provisão, e recolhendo ao Seu novo Cartorio todos os Authos pertencentes a Xiririca, bem como se practicou em Paranaguá na divisão da Vara de Iguape. O referido M. R. Jozé Francisco de Mendonça pelos seus conhecimentos scientificos adquiridos na Familia de $V$. Excell ${ }^{\mathrm{a}} \mathrm{R}^{\mathrm{ma}}$ e mesmo pela sua gravidade e virtude, hade desempenhar o emprego de Vigario da Vara de Xiririca. E R. M. Despacho de S. $E x^{a} R^{m a}=$ Passe Provisão. São Paulo 11 de Setembro de $1817=$ Rubrica de S. Ex diz = Matheus Abreu Pereira, Bispo ${ }^{649}$.

O bispo de São Paulo, considerando "as bellas qualidades, que concorrem na Pessoa do M. R do Jozé Francisco de Mendonça", atendeu ao pedido do Reverendo de Paranaguá e criou a Vara da Comarca de Xiririca. Assim, os braços da Igreja iam se expandindo. A criação da Vara de Xiririca deve ter auxiliado o trabalho dos párocos sediados em Xiririca, mas a região da capela de Ivaporunduva deve ter continuado isolada. Ou seja, mesmo com a criação de vara própria, os párocos deviam ir a Capela de Ivaporunduva apenas em algumas ocasiões.

Desse modo, leigos, agrupados em torno da Irmandade de Nossa Senhora do Rosário dos Homens Pretos, foram os principais difusores do catolicismo no Médio Ribeira. A Irmandade possuía uma sede (capela de Ivaporunduva), bens móveis e imóveis. Não foi possível saber quando as atividades da Irmandade cessaram - a Irmandade não era oficializada, portanto, não foram feitos muitos registros. Há menção no Livro de Tombo das festas realizadas em homenagem ao orago e da edificação da sede. Podemos imaginar que a Irmandade foi atuante, pelo menos, até meados do século XIX, pois, em 1856 e 1857, terras pertencentes à Irmandade

${ }^{649}$ Livro de Tombo de Xiririca (1816 - 1898). 
foram citadas no "Registro de Terras de Xiririca." 650

Na região de Ivaporunduva, desenvolveu-se um catolicismo fundado em torno das devoções aos santos. Nossa Senhora do Rosário não era a única santa venerada. Mereciam destaque os santos citados no Livro de Tombo de Xiririca - São João Baptista, Santo Antonio de Lisboa e São Benedito - e o santo mais festejado do Vale do Ribeira - o Senhor Bom Jesus de Iguape. Muito importantes também eram as festas do Divino Espírito Santo, a Recomendação das Almas, a Romaria de São Gonçalo e a Festa da Santa Cruz. Essas tradições, típicas do catolicismo popular, alcançaram meados do século XXe, em alguns locais, chegaram até os dias atuais.

650 Sob assento n. 173. Registro de Terras. (barra) Filme 03034, RT 35, Local Xiririca, Volume 25. Arquivo do Estado de São Paulo. Sob assento n. 478. Registro de Terras. (barra) Filme 03034, RT 35, Local Xiririca, Volume 25. Arquivo do Estado de São Paulo. 


\subsection{Dificuldades enfrentadas pelo clero}

\subsubsection{Juquiá}

Nos Livros de Tombo de Iguape e Xiririca, os párocos relataram a ocorrência de "abusos" e "escândalos". Um desses episódios envolveu a disputa dos párocos de Xiririca (Rev. Joze Francisco de Mendonça) e Iguape (Rev. João Chrysostomo de Oliveira Salgado Bueno) por Juquiá, região situada entre as duas localidades. Como a região pertencia a Xiririca, os moradores deveriam cumprir as obrigações religiosas, como a desobriga quaresmal e o batismo, na Igreja Matriz da freguesia. No entanto, alguns moradores alegavam que era mais cômoda a viagem até a Vila de Iguape e cumpriam suas obrigações nessa localidade. Assim, o Reverendo de Iguape, em 1818, enviou correspondência ao Bispo de São Paulo para relatar o "escandalo q' resulta de muito moradores de hum mesmo bairro, q' vivendo juntos reconhecem differentes Parochias, mantendo entre Si disputas e collisoen" ${ }^{651}$.

Na realidade, o problema não era, apenas, o cumprimento das obrigações religiosas em diferentes paróquias. Conforme o Rev. de Iguape, havia moradores em Juquia que, aproveitando-se da confusão gerada pela possibilidade de subordinação a paróquias distintas, não estavam cumprindo as obrigações em nenhum lugar. A situação foi sintetizada pelo bispo de São Paulo (Dom Mattheus de Abreu Pereira), baseando-se nas informações dados pelo suplicante (Reverendo de Iguape), da seguinte forma:

[...] não procurão os Soccorros espirituaes, e nem Satisfazem n'ella Suas desobrigas, e rebeldes ás solicitaçoens e Saudaveis admostaçoens do Supp. ${ }^{e}$, huns recorrem a $\mathrm{Freg}^{\mathrm{a}}$ de Xiririca, e outtos se-deixão ficar n'esse Sertão sem procurarem a lgr ${ }^{a}$, e quando o fazem hé muito tarde em gravame de Suas consciencias, e perigo das Suas almas, do que resulta escandalo de divisoens entre os mesmos moradores, e ter o Supp ${ }^{e}$ muitos Fogos d'aquelles bairro em aberto no Ról de Desobriga, não sabendo assi quem cumpre ou não com os Preceitos da $S^{\text {ta }} \operatorname{lgreja}^{652}$

\footnotetext{
${ }^{651}$ Livro de Tombo de Xiririca $(1816-1898)$.

${ }^{652}$ Livro de Tombo de Xiririca $(1816-1898)$. 
Desse modo, o Reverendo de Iguape, "[...] em attenção a maior facilid ${ }^{\mathrm{e}}$ de recorrerem a esta Igreja, e prócurarem o pasto espiritual, e outras conveninencias temporaes"653, propôs que todos os moradores de Juquiá passassem a dever obediência à paróquia de Iguape. Na prática, o reverendo de lguape estava propondo uma nova configuração do território, no caso, a separação da região de Juquiá da Freguesia de Xiririca e sua anexação à Vila de Iguape. A proposta desagradou o Reverendo de Xiririca, que a rechaçou e frisou que, desde a fundação da Freguesia de Xiririca, Juquiá integrava seu território. Outro fato que demonstrava o pertencimento da região à Xiririca era o recebimento dos "[...] dizimos de todos os moradores do ditto Jyquyá"654. Além disso, ele discordava da suposta maior facilidade de viagem de Juquiá até Iguape: "Hé coisa notoria e incontrariavel, q' a distancia dos ultimos moradores do mencionado Jyquyá até esta Frega ${ }^{a}$. hé consideravel, porem ainda muito maior e mais penosa até a de Iguape" ${ }^{\prime 65}$. Ele reconheceu que $\mathrm{o}$ isolamento da região representava uma dificuldade para o cumprimento das obrigações religiosas e afirmou que o problema só seria resolvido com a criação de freguesia própria e nomeação de um sacerdote. Segundo o Reverendo Joze Francisco Mendonça:

[...] quando se trata de dependencia de Sacramentos e por esta só difficuldade se tornarão frustadas as melhores provid ad em quanto não houver n'aquele retiro Sacerdote encarregado de assistir as necessida ${ }^{\text {es }}$ dos dittos moradores q' já o-tem pertendido alcançar, até que se possa erigir Freg $^{\text {a }}$ separada ${ }^{656}$

No entanto, enquanto não fosse criada freguesia própria, o Reverendo de Xiririca pediu a proteção e a conservação dos seus direitos e dos seus sucessores $^{657}$. Em 1820, o bispo, convencido pela argumentação de Joze Francisco Mendonça ou, talvez, levando em consideração os laços de parentesco que os uniam, acatou o pedido do Reverendo de Xiririca. Contudo, o bispo permitiu que alguns moradores de Juquiá, que nos anos de 1813 e 1815 tinham obtido autorização para cumprirem as obrigações religiosas na Vila de Iguape, continuassem prestando obediência à mesma paróquia.

\footnotetext{
${ }^{653}$ Livro de Tombo de Xiririca (1816 - 1898).

${ }^{654}$ Livro de Tombo de Xiririca $(1816-1898)$.

${ }^{655}$ Livro de Tombo de Xiririca $(1816-1898)$.

${ }^{656}$ Livro de Tombo de Xiririca $(1816-1898)$.

${ }^{657}$ Livro de Tombo de Xiririca (1816 - 1898). 
O conflito entre Xiririca e Iguape revela alguns fatos. Os párocos tinham interesse em aumentar ou, pelo menos, não diminuir o número de pessoas que lhes deviam obediência. O número de fregueses estava relacionado com o dízimo, ou seja, quanto mais fregueses, maior o montante arrecadado. Maior número de fregueses também significava maior número de pessoas que remunerariam o clero pelos serviços religiosos prestados, como casamentos, batismos, enterros, entre outros. Os fregueses também definiam os contornos territoriais, porquanto o território era composto pelos espaços ocupados pelos fregueses de determinada paróquia. $\mathrm{O}$ caso de Juquiá, com fregueses cumprindo obrigações religiosas em paróquias distintas, foi apresentado como exceção.

O clero demonstrou preocupação em ampliar o número de fregueses ("dittos moradores q' já o-tem pertendido alcançar" ${ }^{158}$ ) e controlá-los. Uma das formas de controle era a exigência da certidão da desobriga quaresmal. Por mais que, em Juquiá, alguns moradores tenham conseguido fugir do controle do clero, parece que isso foi mais a exceção do que a regra. Parece que a maioria dos moradores pagavam o dízimo, eram batizados e participavam da desobriga quaresmal. No entanto, o envolvimento com os sacramentos católicos não devia ir muito além disso. O isolamento da região, chamada de "retiro" pelo pároco de Xiririca, devia fazer com que o contato com o clero ocorresse apenas esporadicamente.

Entre os anos de 1820 e 1829, os ventos sopraram a favor da Paróquia de Iguape - Joze Francisco de Mendonça e Mattheus de Abreu Pereira deixaram de ocupar, respectivamente, os cargos de reverendo de Xiririca e de bispo de São Paulo. O Reverendo João Chrysostomo permaneceu no cargo até 1833. Em 1829, Juquiá aparece no Livro de Tombo de Iguape como um distrito da Vila de Iguape. Nesse mesmo ano, o bispo de São Paulo (Dom Manuel Joaquim Gonçalves de Andrade) determinou a criação da Capela de Juquiá. No dia dez de outubro de 1830, o Reverendo João Chrysostomo benzeu a capela edificada.

Assim, o clero prosseguia com o objetivo de ampliar seus braços. No entanto, possivelmente, nenhum pároco foi designado para a capela de Juquiá. Então, talvez, o clero continuasse, relativamente, ausente.

${ }^{658}$ Livro de Tombo de Xiririca (1816 - 1898). 181 


\subsubsection{Capela de Guadalupe}

O culto a Nossa Senhora de Guadalupe foi introduzido em Iguape em 1800. Nesse ano, Lucas da Silva descobriu nas proximidades da Barra do Rio Ribeira uma Imagem da santa ${ }^{659}$. Em 1828, o Reverendo João Chrysostomo relatou que existia uma "pequena Capella, ou Ermida da Senhora de Guadalupe"660 na Praia da Juréia. O patrimônio da capela era composto por cento e cinquenta braços de terra. Desse total, uma parte foi obtida por compra e a outra por doação. Lucas da Silva organizou uma coleta entre os devotos da Virgem de Guadalupe e arrecadou quatro mil-réis. Com esse montante, comprou um terreno (cem braços de terra) pertencente a Raquel de Souza, herdeira de uma parte de uma sesmaria concedida aos seus antepassados pelo Conde da llha do Príncípe (donatário da Capitania da Conceição). Os outros cinquenta braços de terra foram obtidos por doação. Maria Gracia herdou de seu pai, Agapito Gracia, cinquenta braços de terra. Quando Maria Gracia faleceu, o Reverendo Diogo Rodrigues da Silva (pároco de Iguape entre os anos de 1780 e 1820) cuidou do enterro e, por isso, passou a ter direito sobre o terreno. Em seguida, o reverendo de Iguape doou os cinquenta braços de terra ao patrimônio da ermida ${ }^{661}$.

Por volta do ano de 1840 , os moradores da Praia da Juréia solicitaram ao Bispo de São Paulo a concessão de um cemitério. Eles explicaram que, devido à longa distância, não era possível enterrar os mortos na Igreja Matriz de Iguape. Os mortos da Praia da Juréia e das cercanias estavam sendo enterrados na ermida de Nossa Senhora de Guadalupe. No entanto, o fato de os enterros não estarem de acordo com as normas da Igreja Católica causava sofrimento aos moradores da região. Conforme cópia de um requerimento enviado ao Bispo de São Paulo:

Dizem os moradores da Praia da Jurea, abaixo assignados que existindo na dita Praia huma Hermida de Nossa Senhora de Guadalupe, onde se tem sepultado os Defunctos que por impossibilidade não podem ser conduzidos para a Villa, e não havendo alli hum Cemiterio em o qual sejão sepultados

\footnotetext{
${ }^{659}$ YOUNG, 1904, p. 330.

${ }^{660}$ Livro de Tombo de Iguape (1816 - 1854).

${ }^{661}$ Livro de Tombo de Xiririca $(1816-1898)$. 
os corpos dos moradores do dito lugar, e dos mais moradores sircunvizinhos que mais facil lhe seja o recurso para alli, por thes ser impussivel virem para serem sepultados na Matriz por distar della bastante legoas e vendo-se aquelles moradores na necessidade de sepultarem seus Defuntos no mencionado lugar que he prezente hum monturo e por não ser lugar sagrado o que lhes he bastante doloroso por verem assim os seus Defuntos privados da Sepultura Eclesiastica. He Ex ${ }^{\mathrm{mo}}$. Snr. avista do esposto que os Suplicantes abaixo asignados com todo o respeito vem apresença de $\mathrm{V}^{\mathrm{a}}$. Ex $\mathrm{x}^{\mathrm{a}} \mathrm{R}^{\mathrm{ma}}$ implorar a conceção de hum Cemiterio naquelle lugar para bem de serem sepultados em hum lugar sagrado os moradores daquelle bairro, e dos mais vizinhos que ali falecerem. Nestes termos Pedem a Vossa Excellencia Reverendissima se digne attender a justiça de sua supplica de que receberão Mercê ${ }^{662}$.

No dia dezenove de agosto de 1840, o bispo de São de Paulo atendeu a solicitação dos moradores da Juréia e concedeu faculdade ao pároco de Iguape "para que possa benzer o Cemiterio requerido". O pároco de Iguape (Rev. Jose Alves Carneiro) informou o bispo que, no dia quatro de julho de 1841, benzeu "[...] o dito Cemiterio, na dita Praia onde se acha a Hermida de Nossa Senhora de Guadalupe"663. No entanto, nessa mesma correspondência, o reverendo de Iguape contestou o apreço dos moradores da Juréia aos preceitos da Igreja Católica. Ele relatou que esse "abuzo"664 - o sepultamento dos mortos na ermida de Nossa Senhora de Guadalupe) - era muito antigo. E isso ocorria por uma questão de preferência, ou seja, os moradores da Praia da Juréia, assim como dos rios do Una, da Ribeira, das Pedras e de outros locais, preferiam o enterro na ermida ao sepultamento na Vila de Iguape, onde poderia ser realizado termo de óbito e missa. Portanto, para o pároco de Iguape, a verdadeira razão para o sepultamento na ermida não era a dificuldade de transporte e sim a falta de preocupção com a doutrina católica. Ele frisou que os párocos anteriores, Reverendos João Chrysostomo e João Baptista Ferreira, tentaram coibir essa prática, no entanto, não foram bem-sucedidos. O Reverendo Jose Alves Carneiro sublinhou que o abaixoassinado solicitando a criação do cemitério na Juréia só foi feito porque ele convenceu os moradores da Praia da Juréia a realizá-lo. De acordo com o Reverendo Jose Alves Carneiro:

[...] na Praia da Jurea no lugar em que se acha a Hermida de Nossa Senhora de Guadalupe, onde a muitos annos se tinha entroduzido o abuzo de se sepultarem os defuntos, não só daquelle bairro, como dos Rios de

\footnotetext{
${ }^{662}$ Livro de Tombo de Iguape $(1816-1854)$.

${ }^{663}$ Livro de Tombo de Iguape $(1816-1854)$.

${ }^{664}$ Livro de Tombo de Iguape (1816 - 1854). 
Unna, barra do Ribeira, Rio das pedras, e outros muitos lugares, das quaes muito mais facil lhe he o recurso para esta Villa, mas que faltas inteiramente de Caridade Christã, antes querião levar seus defuntos para aquelle lugar, sepulta-los ali privados de todos os sufragios doque trazerem a Villa, onde pudessem ser recomendados e fazer-se o competente termo de Obitas, e manda dizer ao menos huma Missa por sua alma, e por mais deligencias que fizeram os Reverendos Vigarios João Chrysostomo de Oliveira Salgado Bueno, e João Baptista Ferreira, para reprimir esse abuzo, e escandalo não Ihes foi pussivel, até que eu supplicasse a Sua $E^{a} R^{a}$ para que anuisse o Requerimento que persoadi afazerem, pedindo a creação do dito Cemiterio, oqual requerimento sendo por sua $\mathrm{Ex}^{\mathrm{a}}$. $\mathrm{R}^{\mathrm{ma}}$. o Snro ${ }^{\circ}$ Bispo Dom Manoel Joaquim Gonsalves de Andrade, benignamente attendido ${ }^{665}$

O episódio da ermida de Nossa Senhora de Guadalupe tem muitas lacunas. Não foi possível descobrir por que o reverendo de Iguape criticou os moradores da Juréia ao bispo de São Paulo. O reverendo não estava solicitando nada ao bispo, então, possivelmente, estava se defendendo de alguma acusação. Talvez, tenha sido acusado de alguma omissão em relação aos moradores da Praia da Juréia. Se quisessem, tanto ele quanto os reverendos anteriores poderiam ter solicitado ao bispo de São Paulo autorização para benzer o cemitério, mesmo sem o abaixoassinado dos moradores da Praia da Juréia. Além disso, atentando-nos para a rapidez de deterioração de um cadáver, provavelmente, o reverendo, ao enfatizar a facilidade de viagem da Praia da Juréia à Vila de Iguape, estava desconsiderando um problema real. No entanto, talvez estivesse correto quanto ao desinteresse dos moradores da Praia da Juréia, dos rios Una, das Pedras e da Barra do Ribeira pelas práticas católicas. Talvez, moradores de áreas mais afastadas, com pouco contato com representantes do clero, fossem menos inclinados a seguir os dogmas católicos.

Ao longo do século XIX, a ermida de Nossa Senhora de Guadalupe foi utilizada mais como local de sepultamento do que de administração de sacramentos. Ou seja, serviu mais como cemitério do que como capela. No final do século, em 1890, o Vigário Antonio Carneiro da Silva Braga, ao descrever as capelas filiais à Igreja Matriz de Iguape, fez o seguinte comentário sobre a ermida: "[...] a Cappela da Senhora da Guadelupe erécta na Praia da Juréia deste Districto, a qual se acha em lugar remoto, por isso isolada quasi abandonada, servindo quasi que exclusivamente

${ }^{665}$ Livro de Tombo de Iguape (1816 - 1854). 184 
de Cemiterio"666.

Se o local era isolado, seria esperado que fosse subutilizado tanto como capela quanto como cemitério, no entanto, isso apenas ocorria no segundo caso. Então, havia algo que fazia com que o local fosse escolhido como jazigo. O que explicaria a preferência por sepultar os mortos numa pequena capela situada na Praia da Juréia? Talvez, a resposta esteja na proximidade das águas do mar. No Médio Ribeira, há exemplos de cemitérios localizados próximos das águas do rio. Portanto, podemos supor que existisse uma predileção para a realização de sepultamentos nas imediações das águas correntes.

${ }^{666}$ Livro de Tombo de Iguape (1857 - 1903). 


\title{
Capítulo 6 - Águas e Mortos
}

\author{
Os que morreram \\ não se retiraram. \\ Eles viajam \\ na água que vai fluindo \\ Eles são a água que dorme. \\ Os mortos \\ não morreram \\ Eles escutam \\ os vivos e as coisas \\ Eles escutam as vozes da água \\ Birago Diop
}

\subsection{As Águas e os Cemitérios}

No Médio Ribeira, nas Comunidades Remanescentes de Quilombo, perto de rios, localizam-se antigos cemitérios, alguns ainda em funcionamento. Podemos citar os cemitérios localizados nas Comunidades Remanescentes de Quilombo de Peropava (Registro), Ivaporunduva (Eldorado), Praia Grande (Iporanga) e Porto Velho (Iporanga). Nas proximidades dessas comunidades, ainda em funcionamento, há um cemitério no vilarejo do Batatal (Eldorado), onde são enterrados membros da Comunidade Remanescente de Quilombo de Pedro Cubas, e no vilarejo de Castelhano (Iporanga), onde são sepultados membros das Comunidades Remanescentes de Quilombo de Galvão e São Pedro.

O cemitério da Comunidade Remanescente de Quilombo de Peropava localiza-se numa área alagada. Na Comunidade Remanescente de Quilombo de Ivaporunduva, o cemitério antigo localiza-se nas margens do rio Bocó. Atualmente, o cemitério em funcionamento situa-se próximo do Rio Ribeira, um pouco acima da vila. Na Comunidade Remanescente de Quilombo de Praia Grande, existe um cemitério desativado próximo ao Rio Ribeira, na localidade conhecida como Martinho ${ }^{667}$. Na Comunidade Remanescente de Quilombo de Porto Velho, também existe um cemitério antigo próximo ao Rio Ribeira.

667 INSTITUTO DE TERRAS DO ESTADO DE SÃO PAULO. Relatório técnico-científico da Comunidade Remanescente de Quilombo de Praia Grande. São Paulo: Itesp, 2003, p. 38. 
Considerando o risco de alagamento, do ponto de vista prático, delimitar cemitérios nas cercanias de rios e mares não parece uma boa escolha. Talvez, a explicação para essa opção esteja no campo simbólico. A quantidade de cemitérios situados nas proximidades das margens dos rios, em comunidades remanescentes de quilombo, sugere que uma apreensão africana acerca da vida e da morte pode ter influenciado a escolha desses locais. Como visto anteriormente, para os centroafricanos, existiam dois mundos especulares - o mundo dos vivos e o mundo dos mortos - separados por uma massa d'água (kalunga). O trabalho de sistematização das formas de apreensão do mundo dos Kongo, realizado por Kimbwandante Kia Busenki Fu-Kiau, e as pesquisas de Wyatt MacGaffey com os Bacongo da atualidade, demonstraram que essa forma de apreender o mundo podia ser representada por um cosmograma em formato de cruz, o "cosmograma kongo" 668 .

Graficamente, o cosmograma era composto por uma barra horizontal e uma barra vertical. Como já mencionado, a barra horizontal representava as águas (Kalunga). A metade superior era o mundo dos vivos. A metade inferior era o mundo dos mortos. Os quatro pontos da cruz representavam os quatro momentos do sol: a extremidade leste simbolizava o nascer do dia (entrada no mundo dos vivos); a extremidade norte, o meio-dia (apogeu da força no mundo dos vivos); a extremidade oeste, o pôr do sol (entrada no mundo dos mortos); e a extremidade sul, a meianoite (o apogeu da força do mundo dos mortos). Todos os dias, no sentido antihorário, o sol percorria esses quatro pontos cardinais. Ao amanhecer, o sol rompia a fronteira da kalunga e percorria o mundo dos vivos. Ao entardecer, rompia novamente a fronteira da kalunga e entrava no mundo dos mortos. O sol, ao percorrer esses dois mundos, realizava um ciclo, o qual seria repetido no dia seguinte. Portanto, o cosmograma expressa o mito do eterno retorno noite/dia e morte/vida. A morte não significava o fim último, porque a vida de um homem nunca terminava, era eterna. A morte representava um momento de transição.

668 Quanto à validade da formulação contida no "cosmograma kongo" ser aplicada ao passado, conforme Marina de Mello e Souza, "[...] fica evidente que desde os primeiros contatos com os portugueses no final do século XV até os dias de hoje, é basica para os bacongo a divisão entre o mundo dos vivos e o mundo dos mortos". Quanto à abrangência espacial, a mesma pesquisadora ressaltou que "[...] a importância da cruz como símbolo de ligação entre o mundo dos vivos e o mundo dos espíritos diversos ultrapassa as fronteiras dos bacongo, espalhando-se por áreas mais amplas da África central" SOUZA, Marina de Mello. Crucifixos centro-africanos: um estudo sobre traduções simbólicas. In: ALGRANTI, L. M. e MEGIANI, A. P. (Orgs.). Império por escrito: formas de transmissão da cultura letrada no mundo ibérico (XVI-XIX). São Paulo: Alameda, 2009, p. 338-339. 
$\mathrm{Se}$ as águas separavam o mundo dos vivos do mundo dos mortos, os sepultamentos próximos das águas realizados no Vale do Ribeira poderiam ser uma forma de situar os mortos, o mais próximo possível, da sua nova morada. Além disso, a proximidade das águas, portanto, da fronteira, poderia facilitar o contato entre os dois mundos. Embora separados, não estavam totalmente apartados. Compunham fases distintas de um mesmo ciclo. Vivos e mortos formavam uma mesma comunidade, com obrigações recíprocas. Os mortos continuavam se comunicando e interferindo no mundo dos vivos, determinando normas de conduta e fornecendo soluções para problemas terrenos. Assim, mortos sepultados próximos da kalunga, com mais facilidade, poderiam cruzar as águas e chegar ao mundo dos vivos. Também suas mensagens mais facilmente seriam captadas no mundo de cima. Portanto, ao sepultar corpos nas proximidades das águas, os vivos habitantes de um mundo imperfeito, repleto de desventuras - esperavam a visão e a ajuda do mundo dos mortos - a fonte da ventura. Portanto, os sepultamentos próximos das águas podem ser interpretados segundo o paradigma da kalunga.

Alguns pesquisadores também sublinharam a relação entre os mortos e as águas existente na África Central. Regiane Mattos destacou que os Ovimbundu enterravam suicidas ou vítimas de assassinato perto de um rio. Isso garantia uma boa passagem para o mundo dos mortos. Ela frisou que, entre os Mpangu, assim eram enterradas as pessoas que morriam de forma violenta ${ }^{669}$. Macgaffey ressaltou que, para os bacongo, os túmulos e as águas representavam os dois principais meios de comunicação entre "este mundo" - o mundo imperfeito dos vivos - e o "outro mundo" - habitado por ancestrais e espíritos diversos ${ }^{670}$.

\footnotetext{
${ }^{669}$ MATTOS, Regiane Augusto de. De Cassange, mina, benguela a Gentio da Guiné: Grupos Étnicos e formação de identidades africanas na cidade de São Paulo (1800-1850). 2006. Dissertação (Mestrado em História) - Faculdade de Filosofia, Letras e Ciências Humanas da Universidade de São Paulo, São Paulo, 2006, p., 202.

${ }^{670}$ MACGAFFEY, Wyatt. Dialogues of the Deafs: Europens on the Atlantic Coast of Africa. In: SCHWARTZ, Stuart. Implicits Understanding - Observing, Reporting and Reflecting on the Encounters Between Europeans and Other People in the Early Modern Era. Cambridge: The Cambridge University Press, 1994, p. 51. 


\subsection{A Bica Canhambora}

No Vale do Ribeira, a ligação entre túmulos e as águas também pode ser observada num outro local. No século XIX, escravizados em fuga formaram um agrupamento situado a sete quilômetros do núcleo de Iporanga. Anos depois, parte do grupo migrou para onde, nos dias atuais, situa-se a Comunidade Remanescente de Quilombo de Praia Grande ${ }^{671}$. No primeiro agrupamento, foi construída uma bica, a Bica Canhambora. Segundo Relatório Técnico Científico da Comunidade Remanescente de Quilombo de Praia Grande, "[...] nesse local os moradores de Iporanga se reúnem para rezar pelos mortos. Ninguém sabe bem ao certo a origem desse costume"672. Assim, temos uma bica, numa região de confluência de córregos, associada à rezas e festejos em louvor aos mortos. A bica foi nomeada Canhambora por causa de José Canhambora, uma das pessoas enterradas na área. Segundo moradores de Iporanga, outras pessoas também foram sepultadas na bica. Atualmente, apenas uma cova com uma cruz está aparente. Segundo alguns relatos coletados na atualidade, mortos apareciam no local.

Quanto ao aparecimento de mortos na Bica Canhambora, um morador de Iporanga relatou um desses episódios. Esse informante tem 68 anos e nasceu no bairro do Castelhano (Iporanga), nas proximidades das comunidades negras de Galvão e São Pedro, de onde eram oriundos seus parentes. Ele morou no Castelhano até a idade de três anos. Nessa época, seu pai faleceu e sua mãe casou-se novamente. Juntamente com a mãe e o padrasto, o informante foi morar no Sítio Soares, depois nomeado Sítio das Águas Claras, o qual abrangia a Bica Canhambora. Ele explicou que as águas da bica eram utilizadas para mover o engenho de cana e o monjolo. Contou que, um dia, foi pilar arroz no monjolo e, de repente, viu uma senhora corpulenta no local. Ele queria ter conversado com a senhora, mas ficou muito assustado. Quando a mulher se afastou um pouco, ele rapidamente atravessou o rio e voltou para a casa do padrasto e da mãe. Dormiu por 24 horas. O padrasto, que era "vidente", explicou que a senhora vista seria sua irmã, falecida há pouco mais de um mês. O informante gostaria de tê-la conhecido quando

\footnotetext{
${ }^{671}$ INSTITUTO DE TERRAS DO ESTADO DE SÃO PAULO, 2003, p. 29.

672 Ibid., p. 29. 
ela era viva, mas, como ela morava em outro município, em Apiaí, não teve oportunidade. Foi o padrasto - "vidente" e irmão da falecida - que decifrou o que o informante tinha visto na bica.

A história relatada parece ecoar o paradigma da kalunga. Havia uma morta nas proximidades das águas, na bica. $O$ informante, ao distanciar-se da morta, atravessou um rio e voltou para sua casa. Portanto, existia uma barreira de águas um rio - separando o mundo dos vivos do mundo dos mortos. O informante saiu do seu mundo, o mundo dos vivos, atravessou as águas, e entrou no mundo dos mortos. Como esse não era o seu mundo, apesar da curiosidade e do interesse, sentiu medo e voltou para o mundo dos vivos. Após chegar em casa, dormiu por vinte quatro horas. Isso demonstra que a experiência causou-Ihe tamanho desgaste que foram necessárias muitas horas de sono para a recuperação. No entanto, esse período de sono, talvez, representasse que o informante, por algum tempo, ausentou-se do mundo dos vivos. Vinte quatro horas também nos remete ao "cosmograma kongo", pois é o tempo que o sol leva para percorrer os quatro pontos do cosmograma, portanto, é a duração de um ciclo. Foi o padrasto - que era "vidente", portanto, tinha capacidade de compreender o "mundo dos mortos" - que Ihe explicou o que tinha acontecido. Também é interessante notar que existia uma relação de parentesco entre a morta e a única pessoa que conseguiu entender a experiência, o padrasto.

Desse modo, as histórias da Bica Canhambora, nas quais se sobressaem os mortos e as águas, parecem estar alicerçadas em crenças centro-africanas, as quais cruzaram o Atlântico e se enraizaram na América. 


\title{
6.3 O Cemitério de Porto Velho
}

O historiador da arte Robert Farris Thompson enfatizou a influência centroafricana nos cemitérios tradicionais dos negros construídos no sul dos Estados Unidos. De acordo com Thompson: "Nowhere is Kongo-Angola influence on the New World more pronounced, more profound, than in black tradicional cemeteries throughout the South of the United States" ${ }^{1673}$. Voltando para o Vale do Ribeira, o cemitério da Comunidade Remanescente de Quilombo de Porto Velho, também, parece refletir crenças centro-africanas. No Relatório Técnico Científico da Comunidade Remanescente de Quilombo de Porto Velho consta a seguinte informação:

\begin{abstract}
No território reivindicado pela comunidade de Porto Velho existe um cemitério muito antigo onde membros do grupo foram sepultados até 1986. O cemitério é muito simples: uma clareia aberta na mata onde as pessoas eram enterradas em covas rasas cobertas de terra e amontoados de pedras. Também existem pés-de-rosa e uma cruz de ferro feita pelos membros da comunidade de Porto Velho. Estudos feitos pelo Instituto Histórico e Geográfico de São Paulo, em 1908, apontam essa área como tendo um sambaqui. Tudo indica que, posteriormente, foi utilizado pelos negros da região para sepultar seus familiares ${ }^{674}$.
\end{abstract}

Embora não conste no Relatório Técnico-científico, a antropóloga da Fundação ITESP responsável pela elaboração desse documento durante o trabalho de campo, realizado em 2002, notou a presença de outros objetos. Ela observou que existiam garrafas perto de algumas covas. Também viu velas pretas, vermelhas e brancas. Sobre uma cova, tinha uma foice e uma enxada. Sublinhou que o cemitério era circular e, tão próximo do Rio Ribeira, que dava para ouvir o barulho das águas $^{675}$.

Quanto às garrafas, Thompson sublinhou que, no Congo e em Angola, existiu o costume de amarrar e suspender garrafas, formando uma "bottle tree". Esse

\footnotetext{
${ }^{673}$ THOMPSON, Robert Farris. Flash of the Spirit: African and afro-american art and philosophy. New York: Vingage Books, 1984, p. 132.

674 INSTITUTO DE TERRAS DO ESTADO DE SÃO PAULO. Relatório técnico-científico da Comunidade Remanescente de Quilombo de Porto Velho, p. 34.

${ }^{675} \mathrm{O}$ Relatório Técnico Científico da Comunidade Remanescente de Quilombo de Porto Velho foi assinado pela antropóloga Patrícia dos Santos Scalli. 
costume foi observado nos dois lados do Atlântico no final do século XVIII - em 1776, em Loango e, em 1791, em Dominica. As garrafas eram amarradas em árvores localizadas próximas a uma casa e tinham o objetivo de protegê-la de maus espíritos. Thompson notou, na América, o aumento da "creole tradition of the bottle tree". Nos anos 80 do século XX, a tradição foi observada na Guiana, no Suriname, na Ilha de Trinidade e nos Estados Unidos (do Texas até Carolina do Sul, com concentração em Virginia, Arkansas, Mississippi e Alabama). Ela existia similarmente no Congo. Conforme Thompson:

Today the function of similar expressions presiding over Kongo graves is the
blocking of the disappearance of the talents of the important dead. Lifting up
their plates or bottles on trees or saplings also means "not the end", "dead
will not end our fight", the renaissance of the talents of the dead that have
been stopped, by gleaming glass and elevation, form absortion in the
void $^{676}$.

De acordo com Thompson, no Texas, "[...] grave glass will keep the 'evil spirits away' or 'keep away the man's spirit'. In that sense Afro-American bottle tree are fugitive specters from a graveyard realm, just as bottle-lined burials area horizontal bottle trees" 677 .

No cemitério do Porto Velho, as garrafas não estão suspensas. Elas estão ao lado de algumas covas. Não sabemos seu significado. De qualquer forma, a presença de garrafas pode revelar um ponto de conexão entre a Comunidade Remanescente de Quilombo de Porto Velho, a África e outras regiões do Atlântico que receberam centro-africanos. As roseiras plantadas no cemitério podem ser outro ponto de contrato entre Porto Velho e o Atlântico Negro. Thompson observou que algumas árvores foram plantadas em cemitérios no Congo, no Haiti e nos Estados Unidos (Mississipi, Carolina do Sul e Texas). Conforme esse pesquisador, as árvores simbolizavam os espíritos, pois as raízes, literalmente, viajavam em direção ao outro mundo - o mundo debaixo, o mundo dos mortos. Se as árvores floresciam, significava que o espírito estava bem ${ }^{678}$. Dessa forma, pode ser que crenças semelhantes tenham embasado o plantio de pés-de-roseira no cemitério do Porto Velho.

\footnotetext{
${ }^{676}$ THOMPSON, 1984, p. $144-145$.

${ }^{677}$ Ibid., p. 145.

${ }^{678}$ Ibid., p. $138-139$. 
O vínculo entre Porto Velho e a África também pode ser sugerido pela presença das velas brancas, pretas e vermelhas. Embora velas apontem, muito fortemente, para a relevância da herança europeia, Thompson destacou sua importância para os centro-africanos - simbolizavam a iluminação do caminho para a glória. Conforme esse pesquisador, "[...] among other kongo influences on New World black burials are deposits of lamps to light the way to glory"679. Especificamente quanto às cores, as velas de Porto Velho apontam para o peso das tradições centro-africanas. Esse aspecto foi abordado por MacGaffey e Monica Schuler. MacGaffey associou a cor preta ao mundo dos vivos, e as cores branca e vermelha ao mundo dos ancestrais e outros espíritos ${ }^{680}$. Monica Schuler também associou a cor preta ao mundo dos vivos, e a cor branca ao mundo dos mortos. No entanto, ela fez algumas considerações sobre o vermelho. Relacionou o vermelho com o sangue e com os dois momentos de transição contidos no "cosmograma kongo". A cor vermelha representava os dois momentos que as águas da kalunga eram rompidas pelo sol, ou seja, o amanhecer (entrada no mundo dos vivos), associado ao nascimento; e o por do sol (entrada no mundo dos mortos), associado à morte ${ }^{681}$. Portanto, as cores das velas do cemitério de Porto Velho - brancas, vermelhas e pretas - podem ter relação com crenças centro-africanas.

O formato circular do cemitério também chama atenção. T. J. Desch Obi, ao estudar a capoeira do Brasil, frisou a importância do "cosmograma kongo" para a compreensão da prática. Ele associou a roda de capoeira à trajetória que o Sol realiza ao percorrer o mundo dos vivos e o dos mortos, dado que o Sol movimentase em sentido anti-horário e seu percurso forma um círculo. Da mesma forma, os participantes da roda de capoeira formam um círculo e dançam em sentido antihorário. Sterling Stuckey estudou rituais circulares em várias regiões da África e da Ámerica. Ele afirmou:

There is, in fact, substancial evidence for the importance of the ancestral function of the circle in West Africa, but the circle ritual imported by Africans

\footnotetext{
${ }^{679}$ Ibid., p. 139.

${ }^{680}$ MACGAFFEY, Wyatt. Dialogues of the Deafs: Europens on the Atlantic Coast of Africa. In: SCHWARTZ, Stuart. Implicits Understanding - Observing, Reporting and Reflecting on the Encounters Between Europeans and Other People in the Early Modern Era. Cambridge: The Cambridge University Press, 1994, p. 51.

${ }_{681}$ SCHULER. Monica. Liberated Central Africans in Nineteenth-Century Guyana. In: HEYWOOD, Linda M. (Ed.). Central Africans and Cultural Transformations in the American Diaspora. Cambridge: Cambridge University Press, 2002 p. 345.
} 
from the Congo region was so powerful in its elaboration of a religious vision that it contributed disproportionately to the centrality of the circle in slavery. The use of the circle for religious purposes in slavery was so consistent and profound that one could argue that it was what gave form and meaning to black religion and $\operatorname{art}^{682}$.

$\mathrm{Na}$ roda de capoeira, os participantes, ao movimentarem-se em sentido antihorário, uniam o imperfeito mundo dos vivos ao potente mundo dos mortos. Ao ficarem de ponta-cabeça, caminhando com as mãos, os participantes da roda, metaforicamente, estavam caminhando no poderoso mundo dos mortos. Agindo dessa forma, conseguiam maximizar seus poderes ${ }^{683}$. Da mesma forma, pode ser que o formato circular do cemitério do Porto Velho também tenha o propósito de unir os dois mundos e seja a expressão de um desejo dos vivos de obter a ajuda e a proteção dos mortos. Portanto, pode ser que a escolha do formato do cemitério no Porto Velho esteja ancorada na importância do círculo para os centro-africanos.

Outro ponto que sugere, fortemente, a influência das tradições centroafricanas na Comunidade Remanescente de Quilombo de Porto Velho é a presença de ferramentas agrícolas (enxada e foice) e, também, da cruz de ferro. A presença desses objetos ecoa a importância do ferro para a sociedade africana.

Para a compreensão da importância desse metal para os centro-africanos, é preciso entender o mito do rei-ferreiro, largamente disseminado na África Central. Juliana Ribeiro da Silva destacou que, até mesmo na atualidade, esse mito é encontrado: "os mitos ligados aos reis-ferreiros estavam e estão presentes em muitas sociedades africanas" ${ }^{\prime 64}$. Ou seja, o mito tem ampla abrangência espacial e temporal. Segundo o mito, os ferreiros aparecem como conquistadores e, consequentemente, como reis-fundadores ${ }^{685}$. De fato, muitas regiões da África Central passaram a ser povoadas por causa da existência de minas de ferro. E muitos chefes controlavam essas minas e o ofício da metalurgia. No entanto, nem

682 STUCKEY, Sterling apud OBI, T. J. Desch. Combat and the Crossing of the Kalunga. In: HEYWOOD, Linda M. (Ed.). Central Africans and Cultural Transformations in the American Diaspora. Cambridge: Cambridge University Press, 2002 p. 366.

${ }_{683} \mathrm{OBI}, \mathrm{T}$. J. Desch, Combat and the Crossing of the Kalunga. In: HEYWOOD, Linda M. (Ed.). Central Africans and Cultural Transformations in the American Diaspora. Cambridge: Cambridge University Press, 2002, p. 367-369.

684 SILVA, Juliana Ribeiro da. Homens de ferro: os ferreiros na África Central no século XIX. Dissertação (Mestrado em História) - Faculdade de Ciências Humanas da Universidade de São Paulo, p. 41.

${ }^{685}$ Ibid., p. 40. 
sempre os chefes africanos detinham os saberes ligados à metalurgia e, muitas vezes, a associação entre o chefe e o ferro ocorria no campo simbólico ${ }^{686}$. Segundo Juliana Ribeiro da Silva, "[...] não eram todos os chefes que de fato dominavam a metalurgia do ferro, nem eram todos que detinham o controle de minas de ferro ou de sua produção, mas quase todos relacionavam sua origem a algum ancestral detentor do conhecimento da metalurgia do ferro"687. Conforme destacado por Cavazzi, esse era o caso dos primeiros chefes do Congo, por ser o domínio do ferro a "[...] arte dos primeiros reis do Congo. Assim, sobre os seus sepulcros aparecem em boa ordem: martelo, foles e bigornas com uma coroa por cima, como prerrogativa particular desta arte tão nobre e tão respeitada". 688

O mito do rei-ferreiro revela a profunda relação entre ferro e poder. Muitos povos da África Central utilizavam insígnias de poder feitas de ferro. Ao estudar os povos ambundo, Joseph Miller destacou que objetos de ferro eram utilizados como símbolos de linhagem, conferindo poderes especiais e autoridade aos seus detentores $^{689}$. Os povos ambundos descendiam dos Samba, cujos governantes possuíam o título de musuri - palavra que significa "ferreiro" em quimbundu. O reifundador dos Samba, "Ngola-Musuri", dominava a tecnologia do ferro e sua competência técnica permitiu aos ambundos fazer machados, facas e pontas de flecha. Entre os povos kuba, quioco, lunda e ovimbundu, os objetos que simbolizam o poder também eram feitas de ferro ${ }^{690}$. Além de serem utilizadas como insígnias de poder, objetos de ferro, como o martelo e a bigorna, eram utilizados em cerimônias de entronização do novo chefe. Por exemplo, entre os povos tio, o novo soberano recebia um colar de ferro - o mais alto símbolo de poder - forjado pelo ferreiro ${ }^{691}$.

A metalurgia possibilitou a produção de ferramentas agrícolas, como a enxada, as quais contribuíram para o aumento da produtividade dos campos, ou seja, para a fertilidade ${ }^{692}$. No campo simbólico, o ferreiro estava associado à fertilidade dos campos e também das mulheres. Isso ocorria devido à relação entre o

\footnotetext{
${ }^{686}$ Ibid., p. 36.

${ }^{687}$ SILVA, op. cit., p. 60.

${ }^{688}$ MONTECÚCCOLO, 1965, livro primeiro, p. 127.

${ }^{689}$ MILLER, Joseph C. Poder politico e parentesco: Os antigos estados mbundu em Angola. Trad. De Maria da Conceição Neto. Luanda: Arquivo Nacional/ Ministério da Cultura, 1995, p. 63.

${ }^{690}$ SILVA, op. cit., p. 58-59.

${ }^{691}$ SILVA, op. cit., p. 57-63.

${ }^{692}$ SILVA, op. cit., p. 35. 
ferreiro e os espíritos locais responsáveis pela fertilidade das mulheres e dos campos, os bisimbi ${ }^{693}$. MacGaffey sublinhou que a ligação entre os bisimbi e o ferreiro era tão forte que, em muitas regiões, o ferreiro era visto como o sacerdote dos bisimbi. Conforme esse pesquisador, algumas fontes "tell us that smithing 'comes from the water simbi"'694. Dessa forma, havia uma relação entre os ferreiros e os espíritos das águas ${ }^{695}$. Conforme já visto, os espíritos das águas, também, estavam relacionados com as pedras. MacGaffey e Slenes sublinharam que espíritos das águas moravam em pedras, assim como algumas narrativas associam o ferreiro com as pedras. MacGaffey destacou que a iniciação do ferreiro "[...] required that a large stone be brought from the river, in due form, to stand in his smithy; usually such stones are simbi objects"696.

Ferro e pedra, elementos tão estimados pelos centro-africanos, estão presentes nas ferramentas, na cruz e sobre as covas do cemitério do Porto Velho. Além do seu material, o formato da cruz também merece destaque, pois pode ser vista como a representação do próprio "cosmograma kongo". Assim, sob o prisma centro-africano, nas margens do Rio Ribeira/ Kalunga, o cemitério do Porto Velho pode ser a materialização de um forte anseio de se obter ventura, e, assim, aliviar as desventuras do cotidiano.

\footnotetext{
${ }^{693}$ SILVA, op. cit., p. 53.

${ }^{694}$ MACGAFFEY, Wyatt. Relion and society in Central Africa: The Bakongo of Lower Zaire. Chicago: The University of Chicago Press, 1986, p. 67.

${ }^{695}$ Embora estejamos destacando a associação dos Bisimbi com as águas, eles também estavam presentes na terra. Conforme Slenes: "Tanto as literaturas históricas quanto as etnográficas deixam claro que os basimbi são deidades territoriais locais; sua associação particular com água reflete a importância desse elemento para a fertilidade da colheita e para o bem-estar da comunidade, mas ela não circunscreve seus limites de ação (devido à sua presença também na terra)". (SLENES, Robert. A Grande Greve do Crânio do Tucuxi: Espíritos das Águas Centro-Africanas e Identidade Escrava no Início do Século XIX no Rio de Janeiro. In: HEYWOOD, Linda (org). Diáspora negra no Brasil. Tradução Ingrid de Castro Vompean Fregonez, Thaís Cristina Casson e Vera Lúcia Benedito. $1^{\text {a }}$ ed. São Paulo: Contexto, 2009, p. 207.)

${ }^{696}$ MACGAFFEY, op. cit., p. 67. 


\section{Capítulo 7 - As Águas e os "Curadores de Feitiço"}

\subsection{Cruz, Crucifixo e Rosário}

Podemos relacionar as cruzes da Bica Canhambora e do Cemitério com o "cosmograma kongo", mas não podemos deixar de frisar que a cruz é o mais importante símbolo do cristianismo. Portanto, as cruzes citadas demonstram que as populações que enterraram seus mortos no Porto Velho e na Bica Canhambora também eram católicas.

A adoração à cruz católica foi incentivada nos dois lados do Atlântico. Do lado de cá, a ocorrência da "Festa de Santa Cruz", realizada no dia 03 de maio, nas comunidades negras do Médio Ribeira até os dias atuais, aponta para o enraizamento dessa tradição na localidade. Do outro lado do Atlântico, na mesma data, a cruz era da mesma forma celebrada. Cavazzi citou a realização de uma festa no Congo, em São Salvador, no dia 03 de maio, em louvor à "Santíssima Cruz de Cristo"697.

No Vale do Ribeira, as grandes distâncias e os rios tornaram o trabalho de evangelização mais difícil, no entanto, como visto anteriormente, o clero esforçou-se para a propagação a fé católica. Os vigários empenharam-se em administrar os sacramentos, principalmente o batismo e a comunhão, na época da Quaresma. As irmandades, ao dedicarem-se ao culto aos santos, também contribuíram significativamente para a difusão do catolicismo na região. Dessa forma, as populações do Vale do Ribeira foram cristianizadas.

Marina de Mello e Souza destacou a semelhança entre a cruz católica e o "cosmograma-kongo", sublinhando que, na África Central, essa associação já era feita. Assim, pode ser que logo no início da evangelização - seja no Vale do Ribeira ou na África - a cruz católica tenha sido entendida pelos centro-africanos como a

${ }^{697}$ MONTECÚCCOLO, 1965, p 237-238. 
representação do "cosmograma-kongo".

Em relação ao trabalho de evangelização ocorrido na África Central, Marina de Mello e Souza ressaltou que, levando-se em consideração que a cruz era vista como símbolo do ciclo eterno da vida e da possibilidade de comunicação entre o mundo dos vivos e o dos mortos, entende-se "[...] melhor a facilidade com que a cruz católica foi adotada e a importância que logo ocupou entre os objetos com poderes especiais, colocados em altares, reverenciados, usados como amuletos de proteção, como insígnias de poder, como portadores de boa sorte e abundância" ${ }^{\text {"998 }}$.

José da Silva Horta, ao pesquisar objetos citados nas inquirições do Santo Ofício realizadas em Angola entre 1596 e 1598, mencionou que eram comercializados crucifixos e rosários nas feiras do interior do Congo, ou seja, em locais não percorridos pelos missionários ${ }^{699}$. No Congo, conforme Marina de Mello e Souza:

Na segunda metade do século XVII o reino estava cheio de cruzes de madeira e as pessoas saudavam-nas devotamente, ajoelhando-se frente a elas. Havia cruzes nas entradas e praças principais das aldeias, nos altares dos espíritos locais, em cemitérios e em vários locais tradicionais de culto $^{700}$.

Cruzes, rosários e imagens de santos, nos primeiros tempos da cristianização, foram chamados de minkisi pelos próprios missionários. O objetivo era fazer a tradução desses objetos para o universo mental centro-africano ${ }^{701}$. Para os centro-africanos, minkisi eram objetos relacionados aos espíritos da terra e das águas e para eles se pedia, entre outras coisas, fertilidade. Geralmente, esses objetos eram do mundo natural, mas tinham uma aparência não usual, como uma pedra ou um pedaço de madeira com formato estranho. Como os minkisi eram receptáculos do poder dos espíritos da terra e das águas, ao utilizá-los acessavamse os poderes desses espíritos. Por garantirem acesso ao mundo espiritual, os minkisi eram utilizados em julgamentos e em ritos de adivinhação e cura. E, de fato, objetos de cunho católicos, como crucifixos, rosários e imagens de santos,

\footnotetext{
${ }^{698}$ SOUZA, Marina de Mello, Crucifixos centro-africanos: um estudo sobre traduções simbólicas. In: ALGRANTI, L. M. e MEGIANI, A. P. (Orgs.). Império por escrito: formas de transmissão da cultura letrada no mundo ibérico (XVI-XIX). São Paulo: Alameda, 2009. p. 339.

699 Ibid., p. 339.

700 Ibid., p. 339.

${ }^{701}$ SOUZA, Marina de Mello e Souza. Santo Antonio de nó-de-pinho e o catolicismo afro-brasileiro. Tempo, Niterói, v. 6, n. 11, 2001, p. 174. 
passaram a ocupar lugares equivalentes aos dos minkisi. Assim, a cruz (com Cristo e sem Cristo), integrada num conjunto maior de objetos e substâncias, foi utilizada em ritos de cura, aplicação de justiça e legitimação do poder dos chefes ${ }^{702}$.

Em Iguape e Xiririca, "curadores de feitiço" praticavam ritos de adivinhação e cura com rosários e cruzes. Nos momentos de infortúnio, eram aos "curadores de feitiço" que as pessoas recorriam. E era justamente na atuação desses curadores que a herança centro-africana emergia com todo o seu vigor.

\section{2 "Curadores de feitiço" em Iguape}

Abordaremos o discurso proferido por um dos membros da Câmara da Vila de Iguape, Luiz Alvares da Sessão, na sessão ocorrida no dia 11 de julho de 1833. Conforme já relatado, nos anos seguintes, Luiz Alvares ampliaria seu prestígio social e sua fortuna. Tornar-se-ia procurador da Irmandade do Senhor Bom Jesus de Iguape, a irmandade mais rica da vila, e receberia o título de comendador. Também, nos anos vindouros, Luis Alvares enfrentaria o clero local para que a irmandade do Bom Jesus se apropriasse da nova Matriz. Em 1833, aos 25 anos, o seu alvo foram dois "curadores" negros.

O discurso de Luiz Alvares na Câmara da lguape contra os "curadores de feitiço" sustentava-se sobre alguns pilares. O primeiro pilar abordava a oposição "natureza versus cultura". Na primeira frase, ele enfatizou que os curadores viviam em um estado de natureza, não tinham humanidade, e essa ideia repetiu-se ao longo do discurso. A denúncia começou dessa forma: "A dois annos mais ou menos que de entre as brenhas aparecerão dous individuos" ${ }^{703}$. Numa outra parte do discurso, ele afirmou que conhecia um dos curandores há mais de 15 anos, portanto, "brenhas" tinha sentido figurado. Foi um recurso utilizado para apresentar

\footnotetext{
${ }^{702}$ SOUZA, 2009, p. 337-349.

${ }^{703}$ Atas da Câmara de Iguape (ano 1833). Coleção Prefeitura Municipal de Iguape - Arquivo do Museu Paulista. 
os curadores como seres provenientes de locais desprovidos de cultura. $\mathrm{Na}$ sequência, estabeleceu uma confusa relação "natureza versus civilização". Parece que ele considerava o universo cultural fruto da natureza e não do relacionamento entre os homens. Ele afirmou que os curadores eram "falto de conhecimento" e explicou: "[...] falto de conhecimento quero dizer porque a natureza nem ao menos Ihe confiou a mais pequena luz de sevelização". Parece que Luiz Alvares acreditava que os curadores tinham outra natureza, desfavorável à aquisição de conhecimento. Ou seja, eles eram "bárbaros" devido aos imperativos do mundo natural e não existia, sequer, a possibilidade de transformarem-se em seres civilizados. Num outro trecho, voltou, novamente, à questão "natureza versus cultura", mas de outra forma. Ele afirmou que os curadores não tinham conhecimentos mínimos - obtidos através da mais simples observação da natureza. Luiz Alvares afirmou que um deles não sabia utilizar ervas nem para tratar doenças corriqueiras: "[...] sem que ao menos conheça a virtude simples de húa erva, nem mesmo pratica para applicação dellas na mais leve doença caxeira". Foi contra o curandor Ignácio que as críticas foram mais duras. Foi definido como ainda "mais bruto, mais bárbaro" e "[...] hum cavador de terra, e por consequencia hum individuo sem arte, sem luzes, emfim sem principio algum". Ignacio só dispendia energia (cavava), mas não cultivava a terra, não praticava a agricultura. Esse foi mais um recurso para enfatizar seu argumento a falta de cultura, civilidade, religião e princípios morais dos curadores.

O segundo curador era forro - "foi hum Henriques" - e atendia na Barra do Juquiá. A região ficava na divisa entre Xiririca e Iguape. Distante dos dois núcleos, o clero tinha dificuldade em controlá-la. Conforme já exposto ${ }^{704}$, o pároco de Iguape criticou o "abuso" de pessoas, da mesma localidade, atenderem a diferentes paróquias. Ele relatou que algumas pessoas, aproveitando-se da situação, não estavam cumprindo as obrigações religiosas em nenhuma das duas paróquias. Portanto, na barra de Juquiá, as pessoas recorriam aos curadores de feitiço para lidar com as necessidades do mundo material e espiritual.

Ignácio, o primeiro curador, era escravizado. Estabeleceu-se na Capara, depois na Barra do Rio Ribeira e, em seguida, na Barra do Una. Esses lugares eram relativamente isolados - o que dificultava o controle exercido pelas autoridades de

${ }^{704}$ Conforme exposto no Capítulo 5 (item 5.3.1 - Juquiá). 200 
Iguape. A Barra do Una também era uma região de fronteira - divisa entre Iguape e a Vila de Itanhaém. Conforme visto anteriormente, em 1840, o pároco de Iguape relatou ao bispo de São Paulo que os mortos da região dos "Rios de Unna, barra do Ribeira, Rio das pedras, e outros muitos lugares" eram enterrados na Capela de Guadalupe. Segundo o pároco, isso acontecia por "falta inteiramente de Caridade Christãan ${ }^{705}$. Ou seja, para o pároco, as pessoas da região não estavam comprometidas com os dogmas católicos. Portanto, as necessidades da esfera espiritual não eram solicitadas ao clero, nem atendidas pelos párocos. Luiz Alvares parece apontar para onde a demanda convergia. A denúncia revela que as pessoas da região recorriam aos curadores para aplacar as dificuldades do mundo temporal e as inquietações do mundo espiritual.

A quantidade de pessoas que recorriam aos dois curadores era numerosa e, por isso, eles estabeleceram "casa de hospidagem". No entanto, muitas vezes, esses estabelecimentos eram fechados pelas autoridades. Foi esse o destino da "casa de Hospidagem" estabelecida em Juquiá pelo "curador de feitiço" forro. Ele sofreu uma reprimenda ("cuja correção lhe servindo de exemplo") e deixou de atuar na região. O curador Ignacio, mais de uma vez, mudou de domicílio para fugir da repressão das autoridades. Quando atendia na "casa de hospidagem" da Barra do Ribeira, "acolheo hûa grande porção" de pessoas. Por temer a "authoridade Policial" do distrito da Barra do Ribeira, mudou-se para a Barra do Una. O Juiz de Paz da localidade não reprimiu suas atividades e Ignacio conseguiu estabelecer-se, com êxito, na região ("adquerido sequito entre elles").

Para o denunciante, Luiz Alvares, que só enxergava força bruta nas ações dos curadores, colocou-se uma questão: como explicar o sucesso de público dos curadores? Para ele, só existia uma explicação: a credulidade das pessoas. Assim, construiu o segundo pilar do seu discurso, a desqualificação das pessoas que procuravam os serviços dos curadores. Luiz Alvares utilizou termos como "classe acreditadora de tudo", "mizeraveis que acreditão em hão orrorozo nome" (dos curadores), "credulos", "desgraçados que tudo acreditão", "infelizes de quem se fez acreditar como curador". A credulidade - entendida como sinônimo de falta de ciências e luzes - estava associada a uma determinada camada social: a dos

${ }^{705}$ Conforme exposto no Capitulo 5 (item 5.3.2 - A Capela de Guadalupe). 201 
marginalizados. Assim, para Luiz Alvares, os curadores só faziam sucesso porque sua clientela era formada por "mizeraveis credulos", facilmente iludidos.

Para Alvares, não existiam curadores de feitiço. Ele considerava que os que apregoavam que curaravam "feitiços" eram, na realidade, charlatões que ganhavam a vida aplicando golpes. Também utilizou a palavra "suprestição" para definir o trabalho dos curadores.

James Sweet e Laura de Mello e Souza abordaram o distanciamento entre a elite ilustrada e as camadas populares, no universo das crenças, a partir do século XVII. Conforme Sweet:

No século XVII, o discurso português sobre feitiçaria fundiu-se com um discurso emergente sobre classe social, através do qual uma elite masculina letrada, educada e "civilizada" se procurava distantanciar das massas populares, alegadamente atoladas no mundo vulgar da superstição e da magia ${ }^{706}$.

Para Laura de Mello e Souza, a partir do fim do século XVII, a elite ilustrada se automarginalizou em relação às crenças populares ${ }^{707}$. Assim, na Iguape do século XIX, o preconceito e o ceticismo de Luiz Alvares condiziam com o racionalismo das Luzes que tinha se imposto desde o final do século XVIII ${ }^{708}$.

Para Luiz Alvares, o que os curadores de feitiço faziam não era trabalho. Era justamente o seu oposto, ou seja, uma forma de sobreviver sem ter que trabalhar. Ele explicou a escolha do curador Ignacio pelo ofício da seguinte forma: "[...] mais acentou que a vadição mai de todos os vicios lhe era mais grato, e que porisso devia descubrir hûa outra vida apropriada ao seo bel prazel; expalhou portanto que era curador de feitiços, cuja voz extendeu-se pelos desgracados que tudo acreditão". Também chamou o ofício dos curadores de escandaloso, ínfimo, vergonhoso e

${ }^{706}$ SWEET, James H. Recriar África: cultura, parentesco e religião no mundo afro-português (14411770). Tradução João Reis Nunes. Lisboa: Edições 70, 2007, p. 194.

${ }_{707}$ SOUZA, Laura de Mello. O diabo e a Terra de Santa Cruz: feitiçaria e religiosidade popular no Brasil colonial. São Paulo: Companhia das Letras, 2009, p. 326.

${ }^{708}$ No Livro de Tombo de Xiririca, há uma passagem, citada anteriormente, que demonstra a associação entre "conhecimentos científicos" e posição social. Quando o reverendo de Paranaguá indicou o Reverendo Joze Francisco (parente do Bispo de São Paulo) para o cargo de vigário da vara, justificou sua escolha ao bispo da seguinte forma: "[indico] o referido M. R. Jozé Francisco de Mendonça pelos seus conhecimentos scientificos adquiridos na Familia de V. Excell. e mesmo pela sua gravidade e virtude". O rev. de Paranaguá atrelou os conhecimentos científicos do reverendo de Xiririca à família a que ele pertencia - a família do bispo. Ou seja, conhecimentos científicos estavam, claramente, associados à posição social. 
maldito. Desse modo, Luiz Alvares construiu o terceiro pilar de sustentação do seu discurso, a desqualificação das práticas de cura. Para isso, começou descrevendo a consequência da ação dos curadores - a ruína e a desmoralização de pessoas e famílias. Por exemplo, na Barra de Juquiá, o curador forro causou "desgraça" a uma família, a qual "pox em estado de malquerencia geral". Quanto ao curador Ignacio, enquanto "fazia sua fellecidade", "tem emfelicitado os mizeraveis credulo". Luiz Alvares relatou que Ignacio difamava as pessoas, afirmando que elas eram responsáveis por algum mal, e, em seguida, elas caíam em desgraça. Nas palavras de Luiz Alvares, Ignacio agia "[...] derramando a discordia entre as familias a quem elle indegitava como factores de taes males, pondo as assim em hum total abandano e desprezo entre seos vizinhos sem outro socorro mais que as lagrimas".

Portanto, as pessoas que consultavam os curadores de feitiço vinham com uma determinada queixa e o curador desvendava os responsáveis pela ocorrência do mal. Essa forma de lidar com o infortúnio parece típica dos centro-africanos. Muitos anos antes, no século XVII, na África Central, Cavazzi observou que as pessoas procuravam especialistas em práticas mágico-religiosas para descobrir quem estava causando um mal específico ou tinha provocado a morte de um familiar. Um desses especialistas era chamado de "ngombo". Cavazzi descreveu a ação do ngombo da seguinte maneira: O pior engano em que o ngombo mantém a gente ignorante é fazer
acreditar que nenhum homem ou mulher pode chegar ao fim da vida senão
por malefício. Portanto, se um doente morrer, atribui a morte a malefício.
Ordinàriamente os parentes recorrem a ele, para que indique o culpado, a
fim de se vingarem ${ }^{709}$.

Conforme já mencionado, de acordo com Marina de Mello e Souza, baseando-se em Fox, Craemer e Vansina, as sociedades da África Central eram orientadas pelo "complexo ventura-desventura". O universo em seu estado normal era harmônico. A desventura (morte, doença, seca, infertilidade) era causada por forças maléficas exercidas por pessoas ou espíritos. As pessoas procuravam os especialistas em conhecimentos e práticas mágico-religiosas para se proteger da desventura e ter ventura. Esses especialistas poderiam utilizar seus poderes para o mal, ou seja, apenas em benefício próprio, ou para causar o mal alheio (feitiçaria),

${ }^{709}$ MONTECÚCCOLO, 1965, livro primeiro, p. 93. 
ou para o bem, ou seja, em prol da coletividade (supressão da feitiçaria) ${ }^{710}$.

Na África Central, o prestígio dos especialistas em práticas mágico-religiosas advinha de sua capacidade de comunicação com o "outro mundo" - formado pelos antepassados, ancestrais e espíritos diversos. Os especialistas realizavam ritos de adivinhação, nos quais buscavam a visão e o conhecimento dos seres do "outro mundo" para solucionar os problemas do mundo dos vivos. Cavazzi observou a existência de diferentes tipos de especialistas em práticas mágico-religiosas, os quais realizavam variados ritos adivinhatórios.

Em Iguape, os curadores denunciados por Luiz Alvares realizavam ritos de adivinhação e também de cura. Luiz Alvares descreveu o rito de adivinhação e cura praticado por Ignácio - ele colocava o rosário da pessoa doente na água fervente, realizava operações nessa água e, depois, utilizava a água no processo de cura. $\mathrm{A}$ utilização da água fervente sugere que crenças centro-africanas norteavam o rito de adivinhação e cura realizado em Iguape - Cavazzi observara a presença de água fervente em algumas práticas centro-africanas. Por exemplo, o tipo de especialista em práticas mágico-religiosas denominado "Mulonga" utilizava o seguinte método de prognóstico:

\begin{abstract}
Põe sobre o lume uma panela cheia de água e de outros ingredientes. Quando a água ferve, mergulha a mão, tirando-a sem prejuízo, para demonstrar que isto é privilégio da sua dignidade. Depois murmura sobre a água o seu diabólico exorcismo e manda-lhes mostrar por sinal se o doente morre ou não. Então, mergulha mais uma vez a mão na água; se a tirar queimada, quer dizer que a morte é certa; se tirar ilesa, declara que o doente será infalivelmente curado. ${ }^{711}$
\end{abstract}

Para Cavazzi, os fenômenos eram explicados pelas forças sobrenaturais.

\footnotetext{
${ }^{710}$ Thornton comparou as visões europeias e centro-africanas acerca da feitiçaria. Ele destacou que, para os europeus, a feitiçaria relacionava-se com o status do sobrenatural, enquanto para os africanos, relacionava-se com a intenção dos vivos. Conforme Thornton: "Tanto os africanos quando os europeus acreditavam que feiticeiros existiam e realmente causavam danos por meios sobrenaturais, e ambas as tradições também possuíam formas de lidar com eles. Entretanto, a idéia de que uma pessoa poderia ser uma feiticeira procurando fazer coisas boas por meio de intervenção diabólica, como os teólogos europeus afirmavam em relação aos seus próprios profetas, videntes e adivinhos, não era uma maneira africana de conceituar o mal, que reside nas intenções dos vivos, e não no status do sobrenatural". (THORNTON, John K. Religião e Vida cerimonial no Congo e Áreas Umbundo, de 1500 a 1700. In: HEYWOOD, Linda (org). Diáspora negra no Brasil. Tradução de Ingrid de Castro Vompean Fregonez, Thaís Cristina Casson, Vera Lúcia Benedito. 1 ed. São Paulo: Contexto, 2009, p.92).

${ }^{711}$ MONTECÚCCOLO, 1965, livro primeiro, p. 97. 
Eles estavam relacionados com Deus ou com o Diabo. Desse modo, o rito descrito acima foi entendido como um "diabólico exorcismo". No Congo, Cavazzi testemunhou outro rito adivinhatório envolvendo água fervente. O objetivo do rito era a revelação do desfecho de uma batalha. Aos olhos de Cavazzi, era um rito de invocação ao demônio. Aos olhos de um centro-africano, era um rito que possibilitava acesso ao "outro mundo", já que os espíritos entravam nas águas e revelavam o futuro.

\footnotetext{
No reino do Congo, declarando-se a guerra, para prever qual será o desfecho dela, põem ao lume um recipiente de água com diversos ingredientes supersticiosos, preparados por alguns sacerdotes idólatras. Estes ritos também existem nas regiões onde se pratica a religião cristã.

Quando a água ferve, invocam o Demônio, obrigando-o, pelo que sei, a entrar naquele recipiente. Depois de algum tempo, interrogam-no sobre o êxito da futura batalha e, se recebem sinais, julgam certíssima a vitória; se não os recebem, consideram inevitável a derrota ${ }^{712}$.
}

Nos dois ritos, pessoas com um infortúnio (doença no primeiro caso e guerra no segundo) procuraram um especialista em práticas mágico-religiosas, que realizou um rito com água fervente e, assim, conseguiu a presença e a manifestação dos espíritos do "outro mundo".

A presença da água no rito de adivinhação e cura também merece atenção. Como já visto, os centro-africanos apreendiam o universo como formado por dois mundos: o "outro mundo" (antepassados, ancestrais e espíritos diversos) e "este mundo" (vivos), separados pelas águas (kalunga). Portanto, o "outro mundo" estava muito próximo das águas, logo abaixo da kalunga, a qual deveria ser frequentemente atravessada.

Considerando a centralidade das águas no universo cultural centro-africano, muito provavelmente, a presença das águas nos ritos de adivinhação e cura era vista como uma forma de viabilizar, facilitar e pontencializar a comunicação entre o mundo visível e o mundo invisível, que coexistem e se interligam. Portando, esses ritos podem ser inscritos dentro de um conjunto de referências culturais centrado no conceito de kalunga.

Já em Iguape, além da presença das águas, há outros elementos que

${ }^{712}$ MONTECÚCCOLO, 1965, livro primeiro, p. 113. 
mostram que o rito realizado por Ignacio filiava-se às crenças centro-africanas. Tanto os ritos descritos por Cavazzi quanto o realizado por Ignacio apresentavam a mesma estrutura - pessoas com algum infortúnio procuravam um especialista em práticas mágico-religiosas, que realizava um rito com água fervente. Nos ritos descritos por Cavazzi, forças espirituais manifestavam-se nas águas. No rito de Iguape, isso também acontecia. Luiz Alvares afirmou que Ignacio realizava operações nas águas, tornando-as aptas para serem utilizadas no processo de cura. Como não relatou nenhuma intervenção no plano material, certamente o que tornava as águas aptas para a cura era alguma intervenção no campo espiritual. Luiz Alvares considerava essas operações nas águas uma afronta à sociedade - era algo tão desrespeitoso que não poderia ser detalhado no centro de poder de Iguape (Câmara). Assim, Luiz Alvares se recusou a relatar as operações realizadas com a água fervente ("operações que aqui se não podem referir").

Acima de tudo, Luiz Alvares considerava os ritos praticados por Ignacio um desrespeito religioso. Estes ritos apresentavam estrutura centro-africana, mas continham um elemento católico - o rosário. Como visto anteriormente, na África Central, cruzes, rosários e imagens de santos foram vistos como "minkisi" (receptáculos do poder dos espíritos da terra e das águas) e foram utilizados em ritos de adivinhação e cura. Não sabemos o local de nascimento de Ignacio e nem onde o rito foi elaborado. De qualquer forma, aqui ou na África, o rito realizado por Ignacio resultou do encontro entre crenças católicas e centro-africanas. E, para Luiz Alvares, esse encontro de crenças, culturas e visões de mundo representava a profanação do catolicismo - "[...] porque este negro demais a profana [a religião] pegando nos Roxarios de diversos doentes e os metendo em agoa a fervir, de cuja agoa fazendo as operações que aqui se não podem referir, della faz uzo para as suas curas."

Com maior ou menor intensidade, a população negra de Iguape entrou em contato com o catolicismo. O clero preocupou-se, especialmente, com o batismo e com a desobriga quaresmal. As irmandades colaboraram, significativamente, para a difusão do catolicismo. Desse modo, os africanos e seus descendentes foram incluídos no mundo católico. Devido à forte atuação das irmandades, a devoção aos santos ocupou papel destacado no cotidiano religioso de Iguape. As irmandades de 
Nossa Senhora do Rosário dos Homens Pretos e a de São Benedito eram voltadas para a população negra de lguape e eram bastante atuantes - realizavam festas concorridas e arcaram com os custos de edificação de uma capela. Na época da denúncia de Luiz Alvares, a irmandade de Nossa Senhora do Rosário, fundada em 1724, tinha mais de cem anos. Rio acima, em Ivaporunduva, existia outra irmandade em louvor a essa santa. Dessa forma, o esforço do clero e das irmandades em prol do catolicismo contribuiu para a cristianização dos africanos e seus descendentes. No entanto, os africanos interpretaram o catolicismo conforme seus próprios pressupostos culturais e o recriaram conforme os seus interesses.

O rito de adivinhação e cura praticado por Ignacio demonstra sua familiaridade com Nossa Senhora do Rosário e aponta para a importância do culto à santa no processo de evangelização de africanos e seus descendentes em Iguape. Isso não ocorreu apenas em Iguape e Xiririca. Nossa Senhora do Rosário foi a principal devoção das Irmandades de Homens Pretos do Império Português - Brasil, África e Portugal. O rito também mostra que esse símbolo do catolicismo, o rosário, foi integrado a um conjunto de crenças centro-africanas. Ele foi utilizado como "minkisi" - como um objeto mágico-religioso que dava poder a quem o manipulava. Ignacio, ao conduzir o rito, manipulava um minkisi, e assim acessava o "outro mundo". Pode ser que Nossa Senhora tenha sido vista como uma ancestral poderosa. De qualquer forma, o rosário tinha o poder de facilitar o contato com o "outro mundo", o qual revelava tanto a causa do mal quanto a sua solução.

Ignacio, a partir de crenças católicas e centro-africanas, elaborou um rito mágico-religioso. No entanto, o encontro de crenças e culturas tinha ocorrido numa sociedade escravista, com relações assimétricas de poder. Dessa forma, Luiz Alvares, representante da elite iguapense, empenhou-se em defender sua visão sobre o rito. Para Luiz Alvares, que interpretava o que era diferente da sua cultura como a ausência de cultura, os ritos praticados por Ignacio representavam as "maiores barbaridades". Ele acreditava que a presença de um símbolo católico numa "suprestição" conduzida por um negro representava uma profanação. Luiz Alvares defendeu que a atuação de Ignacio era um mal, que deveria ser eliminado, caso contrário, causaria uma "funebre consequencia": o fim da religião e da humanidade, ou seja, a barbárie. 
Luiz Alvares expôs seu ponto de vista na Câmara da Vila de Iguape com o objetivo de convencer os membros da Câmara a combater o trabalho dos curadores. Dessa forma, medidas deveriam ser adotadas contra os curadores e, também, contra os que os apoiavam. Alguns representantes da elite iguapense não faziam coro às críticas de Luiz Alvares. Por exemplo, como já mencionado, o Juiz de Paz da Barra do Una não era hostil ao trabalho de Ignacio ("[lgnacio] passou ao districto de Una onde tem praticado as maiores barbaridades sem que o Juiz de Paz d'aquelle Districto desperte para reprimir"), que exercera fator decisivo para o estabelecimento da "Casa de Hospidagem" na localidade ("[lgnacio] asentou que só no Rio de Una fazia sua fellecidade, como de facto ali se acha"). Ignacio não sofreu ameaças e, assim, a "casa de hospidagem" prosperou e ele tornou-se um renomado curador de feitiço. Deve-se levar em conta que, na época da denúncia de Luiz Alvares, a "Casa de hospidagem" da Barra do Una existia há um bom tempo ("onde tem feito epoca").

Porém, outros juízes tomaram diferentes decisões. Os Juízes de Paz da Barra do Rio Ribeira e da Barra do Juquiá não foram tão tolerantes. Antes de ter se estabelecido na Barra do Una, Ignacio tinha uma "Casa de Hospidagem" na Barra do Rio Ribeira. Mas precisou retirar-se, "acossado pelas authoridades desta Villa". Na Barra do Rio Juquiá, uma família, odiada após ser acusada de praticar malefícios, recorreu ao Juiz de Paz contra o autor da acusação - o curador forro. Embora esta família tenha retirado a queixa, Ignacio levou uma reprimenda da autoridade local e deixou de atuar na região.

O grupo dos senhores de cativos também não era homogêneo. Enquanto Luiz Alvares era um ferrenho opositor do trabalho dos curadores, outros senhores adotaram posturas diferentes. Por exemplo, Ignacio contava com o apoio do seu senhor, fato que deixava Luiz Alvares ainda mais indignado. Isso deve ter contribuído para que considerasse Ignacio "mais bruto, mais barbaro" que o curador forro. Conforme Luiz Alvares: "[...] este [Ignacio] como mais bruto, mais barbaro, e mesmo porque obtenha azas do seo Senhor tem emfelicitado os mizeraveis credulos".

Sweet abordou a questão dos ganhos econômicos gerados pelos ritos de adivinhação e cura conduzidos por centro-africanos na Bahia, nos séculos XVII e XVIII. Para Sweet, existiam escravizados que 
[...] trabalhavam claramente como "negros de ganho", efectuando adivinhações e curas para uma série de clientes e dividindo posteriormente os rendimentos com os seus senhores. Em 1705, um homem chamado Domingos Coelho foi acusado de alugar o seu escravo Domingos para adivinhar e curar "nas casas de muitos homens brancos" da Baía. Várias pessoas testemunharam que Domingos "curava e adivinhava com a concordância do seu senhor e dividia com ele os seus rendimentos" ${ }^{713}$

Sweet sublinhou que, embora os escravizados gozassem de certas oportunidades econômicas advindas dos seus poderes religiosos, os senhores também lucravam muito. Conforme esse pesquisador:

\begin{abstract}
Os brancos chegavam a comprar escravos com o objeticto explícito de ganhar dinheiro com as suas curas. Na década de 80 do século XVII, na Baía, Pedro Coelho Pimentel admitiu que adquirira o casal Lucrécia e André "porque the dariam sempre alguns rendimentos das suas curas". Pimentel conhecia a reputação deste casal porque Lucrécia fora propriedade de outros senhores, que tinham recorrido aos seus serviços. Tal como Pimentel planeara, os dois escravos ganharam dinheiro para ele com os seus poderes de adivinhação e cura. $O$ facto de os senhores terem suficiente confiança para adquirir escravos com o único propósito de ganhar dinheiro com as suas curas demonstra que existia uma grande procura no "mercado" de adivinhos e curandeiros africanos, o que constitui uma prova mais da aceitação generalizada do poder religioso centro-africano ${ }^{714}$.
\end{abstract}

Esse deve ter sido o caso do "curador" Ignacio. O proprietário de Ignacio chamava-se Luiz Francisco de Paula e morava numa região conhecida como Capara. Segundo a denúncia de Luiz Alvares, Ignacio começou suas atividades de curador nessa localidade. Depois, foi para a Barra do Rio Ribeira e, em seguida, para a Barra do Rio Una. Os locais de residência de Ignacio, com exceção do primeiro (Capara), estavam vinculados ao local de estabelecimento das casas de "hospidagem", e não ao local de moradia do senhor. Então, provavelmente, Ignacio era um "negro de ganho".

Outro ponto levantado por Sweet e que, possivelmente, também pode ser aplicado a Iguape, foi a clientela dos curadores. Domingos atendia "nas casas de muitos homens brancos" e senhores recorriam aos serviços de Lucrécia. Portanto, pode ser que os senhores de Iguape também procurassem os serviços dos curadores de feitiço. Desse modo, deve ter existido senhores que lucravam com os serviços oferecidos pelos seus cativos e também aqueles que procuravam os

\footnotetext{
${ }^{713}$ SWEET, 2007, p. 182-183.

${ }^{714}$ Ibid., p. 183.

209
} 
serviços dos curadores. Diferentemente, pois, do que Luiz Alvares afirmava, a clientela dos curadores não devia ser formada apenas pelos "mizeraveis", mas também por escravizados, forros, mestiços, brancos pobres, brancos abastados, entre outros. Enfim, esta clientela poderia ter sido formada por representantes dos mais variados segmentos da sociedade.

Assim, o discurso de Luiz Alvares da Sessão, proferido na Câmara, não era apenas contra os curadores. Também era contra os senhores de cativos que permitiam que os curadores trabalhassem livremente e contra as autoridades que não os repreendiam. Diferentemente de outros representantes do grupo dominante (como o senhor de Ignacio e o Juiz de Paz da Barra do Una), Luiz Alvares não fazia nenhuma concessão no campo espiritual. Ele defendia que, até nos lugares mais afastados, apenas o que ele entendia por catolicismo deveria ser praticado. Assim, ele utilizou uma séria de oposições - civilização versus bárbarie, cultura versus natureza, religião versus superstição - para se opor a práticas religiosas diferentes das suas. Ele advogava que nenhuma brecha no campo religioso deveria ser permitida, caso contrário, levaria ao fim da ordem social. Portanto, para ele, era a dominação absoluta, inclusive na esfera religiosa, que garantia a paz na sociedade.

Luiz Alvares expôs suas convicções aos demais membros da Câmara, as quais foram apreciadas e submetidas à votação. Possivelmente, o ponto de vista de Luiz Alvares, mesmo antes da exposição, já predominave entre os membros da Câmara. Luiz Alvares conseguiu a aprovação dos seus pares. A Câmara decidiu que os Juízes de Paz do Rio do Una, da Vila e de Juquiá deveriam ser indagados sobre a existência de curadores de feitiços em seus distritos. Em caso afirmativo, os curadores libertos deveriam ser processados. Quanto aos curadores escravizados, o Juiz de Paz deveria fazer "[...] vir a sua prezença debaixo de Vara ao Senhor, e ahi o constranja a assinar termo de jamais consentir o dito escravo sahir da sua caza, para fora, e nem nella mesma fazer applicação de remedio algum obrigando a desdizer-se que não he Curador de Feitiço".

A Câmara dividiu os curadores em dois grupos - os libertos e os escravizados. Como os dois grupos eram formados pelos africanos e seus descendentes, era contra os curadores negros que a Câmara se opunha. A Câmara não se preocupou com as práticas superticiosas (ou seja, vistas como não católicas) conduzidas por 210 
indígenas ou brancos e se voltou, apenas, contra as práticas realizadas pelos africanos e seus descendentes. Quanto aos demais curadores, ou eles não existiam, ou existiam em número reduzido, ou não incomodavam ${ }^{715}$. Possivelmente, os membros da Câmara protestaram apenas contra os curadores negros porque eram eles que dominavam a preferência do público. Dessa forma, foi o sucesso de público (alicerçado na "aceitação generalizada do poder religioso centro-africano"716 ) que despertou a hostilidade da Câmara para esse grupo de especialistas em práticas mágico-religiosas.

As crenças e práticas realizadas pelos curadores negros de Iguape eram realizadas numa sociedade escravista, portanto, com relações assimétricas de poder. A Câmara da Vila de Iguape - o centro do poder local - julgou-as como nocivas à ordem social, aos costumes e à religião e, porquanto, utilizou seu aparato para eliminá-las. Ela ordenou que as autoridades (Juízes de Paz) localizassem e agissem contra os curadores. Os libertos deveriam ser processados e os proprietários de "curadores" escravizados deveriam ser constrangidos a assinar termo no qual comprometiam-se a proibir que seus cativos trabalhassem como curadores de feitiços. A proibição valia tanto para as práticas realizadas na residência do senhor, quanto em qualquer outro local.

Apesar do empenho da Câmara e de parte significativa da elite de Iguape, as práticas dos curadores de feitiço não foram eliminadas. As medidas adotadas pela Câmara devem ter causado embaraço e, possivelmente, contribuíram para a diminuição em número de curadores. Porém, o ofício continuou sendo praticado. $\mathrm{Na}$ virada do século XIX para o século XX, Young abordou a presença de curandeiros de feitiço em Iguape e fez o seguinte comentário:

Outra crença que, algumas autoridades procuravam eradicar da mente do povo era a denominada "feitiçaria", cuja crença infelizmente ainda tem seus adeptos na população deste municipio. Por mais de uma vez foi tratada em sessão da Camara este assumpto e postas em execução medidas enérgicas contra os intitulados "curandeiros de feitiço", o que os obrigou durante algum tempo a se conservarem occultos, para mais tarde

\footnotetext{
${ }^{715}$ Segundo Laura de Mello e Souza, "[...] africanos, índios e mestiços foram os grandes curandeiros do Brasil colonial. O conhecimento que tinham das ervas e de procedimentos rituais específicos a seu universo cultural atrelou-se ao acervo europeu de medicina popular. Houve curandeiros europeus, mas em número muito inferior". (SOUZA, Laura de Mello. O diabo e a Terra de Santa Cruz: feitiçaria e religiosidade popular no Brasil colonial. São Paulo: Companhia das Letras, 2009, p. 326).

${ }^{716}$ SWEET, 2007, p. 183. 
apparecem com mais ousadia ${ }^{717}$.

Dessa forma, conforme Young, existiam curadores ou "curandeiros" de feitiço em Iguape na passagem para o século XX. Pelo tom desaprovador, evidencia-se a persistência da não aceitação de práticas oriundas de sistemas culturais não europeus. Evidencia-se, também, a longevidade das práticas e crenças dos curadores de feitiço. Young e Luiz Alvares, ao desqualificar os curadores de feitiço e seus consulentes, acabaram por evidenciaram a força e a tenacidade do legado centro-africano.

Abaixo, a ata da sessão da Câmara realizada no dia onze de julho de 1833:

Senhor Presidente. A dois annos mais ou menos que de entre as brenhas aparecerão dous individuos, falto de conhecimento, falto de conhecimento quero dizer porque a natureza nem ao menos the confiou a mais pequena luz de sevelização, chamando e apregoando que curavão feitiços; palavra que envolvem sentido diabolico cuja vôz extendendo a dor pela classe acreditadora de tudo em breves dias cada hum estabeleceo casa de Hospidagem, e ali tenhão frequentado e frequentão mizeraveis que acreditão em tão orroroso nome; hum justamente foi hum Henriques na barra do Juquia, outro hé hum escravo de nome Ignacio de Luiz Francisco de Paula, no bairro da Enceada ou Capara; porém, felizmente o primeiro querendo de hum só golpe iludir muitos desgraçados, que acreditavão em suas Charlatanisse, teve de ser chamado ao Juiz de Paz (que não chegou a comparecer porque a parte que requereo cedeo da sua pertenção) pela desgraça que causou a huma familia, a qual pox em estado de malquerencia geral, cuja correção Ihe servindo de exemplo, cessou da maldita lida de enganar os credulos, mas não acontecio assim com o Segundo, que he o tal escravo Ignacio, este como mais bruto, mais barbaro, e mesmo porque obtenha azas do seo Senhor tem emfelicitado os mizeraveis credulos e de huma maneira tal adquerido sequito entre elles, a ponta de estabelecer sua rezidencia no Districto de Paz de Una onde tem feito epoca depois de ter-se extabelecido na Enceada, ou Capara, e na barra da Ribeira, mais temando-se da authoridade Policial deste Districto, asentou que só no Rio de Una fazia sua fellecidade, como de facto ali se acha, continuando na mais excandaloza, quanto infimo e vergonhoxo Officio. Deste escravo, Senhor Presidente, eu tinho hum vasto conhecimento por conhecer a mais de quinze annos; nunca ouvi, e nem nunca me contou, que fosse mais do que hum cavador de terra, e por consequencia hum individuo sem arte, sem luzes, emfim sem principio algum, sem que ao menos conheça a virtude simples de húa erva, nem mesmo pratica para applicação dellas na mais leve doença caxeira, mais acentou que a vadiação mai de todos os vicios the era mais grato, e que porisso devia descubrir hûa outra vida apropriada ao seo bel prazel; expalhou portanto que era curador de feitiços, cuja voz extendeu-se pelos desgracados que tudo acreditão, teve de ir fazer sua rezidencia na Barra da Ribeira, e ali foi onde acolheo hûa grande porção de infelizes de quem se fez acreditar como curador, derramando a discordia entre familias a quem elle indegitava como factores de taes males, pondo assim em hum total

${ }^{717}$ YOUNG, 1904, p. 360-361. 
abandano e desprezo entre seos vizinhos sem outro soccorro mais que as lagrimas. Outros muitos males Senhor Presidente que longo seria de escrevelos, tem causado a suprestição onde periga a umanidade, e a Religião, porque este negro demais a profana, pegando nos Roxarios de diversos doentes e os metendo em agoa a fervir, de cuja agoa fazendo as operações que aqui se não podem referir, della faz uzo para as suas curas, e sendo emfim acossado pelas authoridades desta Villa, passou ao districto de Una onde tem praticado as maiores barbaridades sem que o Juiz de Paz d'aquelle Districto desperte para reprimir; portanto indico que esta camara tome todas as medidas que julgar convenientes para obstar hum mal de tão funebre consequencia. Paço da Camara Municipal onze de Julho de mil otocentos e trinta e trez - Luiz Alvares da Silva. Sendo posta em discussão foi approvada e deliberou a Camara que se Officiasse ao Juiz de Paz do Rio de Una, e mesmo ao desta Villa, e ao de Juquiá para que haja de indagarem e constando thes que em seos Districtos existem pessoas com taes Officios, digo pessoas que forem libertos, e se intitularem curador de Feitiço os processe na forma da Lei, e os que forem captivos principalmente sobre o que versa a indicação, o Juiz de Paz respectivo faça vir a sua prezença debaixo de Vara ao Senhor, e ahi o constranja a assinar termo de jamais consentir o dito escravo sahir da sua caza, para fora, e nem nella mesma fazer applicação de remedio algum obrigando a desdizer-se que não he Curador de Feitiço ${ }^{718}$.

${ }^{718}$ Atas da Câmara de Iguape (ano 1833). Coleção Prefeitura Municipal de Iguape. Arquivo do Museu Paulista. 


\section{3 "Curandores" nas comunidades negras do Médio Ribeira}

Nos últimos cinquenta anos, as comunidades negras do Médio Ribeira testemunharam a acentuada diminuição do número de "curandores" ${ }^{719}$, o que não impediu que a lembrança de sua existência seja muito presente ${ }^{720}$.

Membros das atuais Comunidades Remanescentes de Quilombo de Iporanga e Eldorado relataram que recorriam aos curandores para solucionar dificuldades terrenas. As pessoas acreditavam que os infortúnios tinham sido causados por alguém, assim, procuravam-nos para descobrir o responsável. Essa maneira de pensar e agir parece semelhante à forma como os centro-africanos (citados por Cavazzi) e os consulentes dos "curadores de feitiço" de Iguape (citados por Luiz Alvares) lidavam com o infortúnio. Um dos pressupostos básicos dos centroafricanos era o "complexo ventura-desventura" - o universo em seu estado normal era harmônico e as desventuras (morte, doença, seca, infertilidade) eram causadas por forças maléficas exercidas por pessoas ou espíritos. Como observou Cavazzi, na África Central, as pessoas procuravam especialistas em práticas mágicoreligiosas para descobrir quem estava causando um mal específico. Com a mesma intenção, as pessoas procuravam os curadores de feitiço de lguape e os curandores do Médio Ribeira.

$\mathrm{Na}$ África Central, os especialistas em práticas mágico-religiosas realizavam ritos de adivinhação, nos quais buscavam a visão e o conhecimento dos seres do "outro mundo" (formado por antepassados, ancestrais e espíritos diversos) para solucionar os problemas do mundo dos vivos. Os curandores do Médio Ribeira

\footnotetext{
${ }^{719} \mathrm{Na}$ ata da sessão da Câmara no dia 11 de julho de 1833, o termo utilizado foi "curador de feitiço"; no começo do século XX. Young utilizou o termo "curandeiro"; e membros das Comunidades Remanescentes de Quilombo do Médio Ribeira empregam o termo "curandores".

${ }_{720}$ Quanto à pertinência da utilização de relatos atuais para a compreensão do passado, Laura de Mello e Souza alertou para os perigos da leitura "para trás" e citou as observações de João José Reis sobre a questão: "[...] sempre perdurará muita dúvida sobre a adequação do método de leitura para trás. Mas talvez seja preferível o risco da ousadia da dúvida do que a dúvida de não arriscar" (REIS, José. Magia Jeje na Bahia: a invasão do Calundu de Pasto de Cachoeira apud SOUZA, Laura de Mello. Revisitando o calundu. In: GORENSTEIN, Lina; TUCCI, Maria Luiza (Orgs.). Ensaios sobre a intolerância: inquisição, marranismo e anti-semitismo, São Paulo: Humanitas, 2005, p. 299). Segundo Laura de Mello e Souza, "[...] aproximações seriam, assim, sempre tentativas, sendo preciso ter claro que o substrato mais passível de permanecer é o de 'certas concepções básicas', o 'das estruturas simbólicas e rituais comuns, e não o dos detalhes'". (SOUZA, op. cit., p. 300). 
também realizavam ritos de adivinhação. Quanto a esses ritos, destacava-se o método de desvendar o passado, o presente e o futuro através da observação de uma garrafa com água. Em termos gerais, o processo poderia ser descrito da seguinte forma: uma pessoa procurava um curandor porque sofria de determinado mal, ele fitava uma garrafa com água e descobria quem estava causando o mal e o que deveria ser feito. Como o "curandor", além de revelar a causa do mal, também prescrevia o que deveria ser feito, pode-se dizer que se tratava de um rito de adivinhação e cura.

Para ilustrar o processo, citaremos um fato ocorrido com uma senhora de 84 anos, membra de uma Comunidade Remanescente de Quilombo de Eldorado. Segundo seu relato, a mãe de seu esposo era contra o seu casamento. Como a sogra era conhecedora de práticas mágico-religiosas, fez um "preparado" com água de ribeirão. A informante pisou no "preparado" e, logo em seguida, perdeu a sanidade. Ela não sabia, sequer, que tinha acabado de ter um filho. A senhora foi levada a um curandor, o qual viu nas águas de uma garrafa que a sogra era a causadora do infortúnio. Também, viu que a informante estava esperando seu segundo filho.

A utilização da garrafa com água pelos "curandores" do Médio Ribeira, o rito do rosário na água fervente praticado pelo "curador de feitiço" Ignacio e os ritos com água descritos por Cavazzi apresentam um ponto em comum - a presença das águas num rito de adivinhação e cura. Como já discutido, os centro-africanos apreendiam o universo como formado por dois mundos - o "outro mundo" (antepassados, ancestrais e espíritos diversos) e "este mundo" (vivos) - separados pelas águas (kalunga). Considerando a relevância das águas no universo cultural centro-africano, a presença das águas nos ritos de adivinhação e cura era vista como uma forma de favorecer a comunicação entre os dois mundos. Portando, o rito de adivinhação e cura realizado pelos curandores do Médio Ribeira, assim como o rito praticado por lgnacio e os ritos descritos por Cavazzi, podem ser inscritos dentro de um conjunto de referências culturais centrado no conceito de kalunga.

De acordo com muitos relatos, os curandores ajudaram muitas pessoas e salvaram muitas vidas. Eles tratavam de vários assuntos, como doenças, parto, busca de parceiros amorosos, entre outros. Nas suas práticas, eles utilizavam vários 215 
materiais, como retalhos, cabelo, ovo, rastro de pegada e, principalmente, raízes e ervas. Na África Central, diversos "matos" eram usados pelos especialistas em acessar o além e, segundo Chatelain, em Angola, remédios naturais para curar doenças eram chamados "mi-longo"721. Evidenciando a ligação com a África Central, no Médio Ribeira, os curandores também eram chamados de "milongueiros"722.

Geralmente, os curandores tratavam os enfermos com orações e garrafadas (preparadas com raízes, cascas, folhas e frutos). Segundo um quilombola de 80 anos, "[...] curandor do mato sabe remédio, mas também sabe judiá dos outros". Essa é uma idéia generalizada no Médio Ribeira - a de que os curandores sabiam fazer o bem e o mal. Dessa forma, esses curandores do Médio Ribeira, assim como os especialistas em práticas mágico-religiosas da África Central, podiam utilizar seus poderes para o bem (em prol da comunidade) ou para o mal (apenas em benefício próprio ou para causar o mal alheio).

Praticar o bem e o mal fazia parte do processo de aprendizagem do futuro curandor. Um curandor experiente the ensinava os dois caminhos. Um quilombola de 66 anos, morador de uma comunidade de Eldorado, relatou que um curandor queria Ihe ensinar o ofício, mas o informante não levou a aprendizagem adiante porque lhe foi dito que teria que matar uma pessoa muito querida ou um animal de estimação. Segundo o mesmo informante, a aprendizagem não costumava ser completa porque os mestres tinham medo de passar todos os seus conhecimentos e, depois, serem mortos pelos ex-aprendizes.

Conforme muitos relatos, existia muita competição entre os curandores. Alguns faziam intervenções na esfera mágico-religiosa que resultavam na morte do seu rival. E eles não matavam apenas seus rivais de ofício. Desentendimentos com "curandores" podiam ser fatais. Conforme um quilombola de 80 anos, um curandor

\footnotetext{
${ }^{721}$ CHATELAIN, 1964, p. 495.

${ }^{722}$ Conforme Fabiana Schleumer, no comentário carregado de "preconceitos e esteriótipos" expresso por José Pinto de Azevedo, aparece a associação entre milongos e remédios. Conforme Azevedo: "[...] a gente preta, não obstante viver com os brancos, aprender os seus costumes, observar a sua religião, e fallar a sua língua, nunca se esquece dos ritos, dos prejuízos, e das superstições gentílicas. Nas suas moléstias não querem professores, nem tomão remédios de botica, porque só tem fé nos seus medicamentos a que chamão milongos, e estes dever ser administrados pelos feiticeiros ou curadores". AZEVEDO, José Pinto apud SCHLEUMER, Fabiana. Bexigas, Curas e Calundus: caminhos da morte entre escravos em São Paulo e seus arredores (Século XVIIII). 2005. Tese (Doutorado em História) - Faculdade de Ciências Humanas e Letras da Universidade de São Paulo, São Paulo, 2005, p. 170.
}

216 
desentendeu-se com o vizinho e, como vingança, "tempero uma jaracuçu", ou seja, fez com que o vizinho morresse após ser picado por uma cobra. Existem muitos relatos sobre casos de vingança - tanto dos curandores que se vingavam dos seus rivais, quanto das pessoas que os procuravam para se vingarem dos seus desafetos. Alguns quilombolas utilizam a palavra "mandracaria" como sinônimo de "vingança". Os curandores podiam matar ou ferir de várias formas - por exemplo, enviando cobras ou outros animais peçonhentos, ou apenas olhando fixamente para o adversário ${ }^{723}$.

Além dos "curandores", existiam outras pessoas com poderes especiais, as quais eram muito respeitadas. Nada lhes era negado, pois se temia uma possível retaliação. As pessoas com poderes especiais podiam causar infortúnio até para aqueles que, mesmo sem querer, tinham lhes causado algum aborrecimento. Esse foi o caso relatado por um quilombola de 75 anos, morador de Eldorado. Ele contou que, quando seu irmão era criança, passou perto de uma prensa e provocou a queda de um burro. A dona do burro, segundo o informante, tinha poderes especiais e era chamada de "feiticeira". Essa mulher levou milho verde ao menino e, após ingeri-lo, a boca e a perna do irmão do informante começaram a inchar. $O$ quilombola correu em direção a casa de um curandor para pedir ajuda. Quando lá chegou, o curandor já sabia que o irmão estava doente e responsabilizou a dona do burro pelo infortúnio. O rezador preparou uma garrafada, a qual deveria ser consumida pelo irmão do informante. Ele afirmou que o irmão conseguiria sobreviver. Segundo muitos relatos, os curandores falavam quem sobreviveria e também quem morreria. Nesse último caso, muitas vezes informavam em quantos dias a pessoa estaria no caixão.

A garrafa com água era um dos métodos de adivinhação. No entanto, não era o único. Conforme relatado na história acima, o curandor já sabia o que tinha ocorrido antes de ter sido avisado pelo informante. Não era necessário que o curandor e a pessoa que sofria do infortúnio estivessem juntas - nem para a revelação da causa do infortúnio, nem para o processo de cura. No relato a seguir,

723 De acordo com o "Inventário cultural de quilombos do Vale do Ribeira", o próprio especialista em práticas mágico-religiosas podia, eventualmente, ser transformado neste animal peçonhento para assustar ou ferir alguém. (ANDRADE, Anna Maria; TATTO, Nilto. Inventário Cultural de Quilombos do Vale do Ribeira. São Paulo: Instituto Sociambiental, 2013, p. 167-168). 
um quilombola de 63 anos, morador de Iporanga, abordou essa questão e chamou de "benzimento pelo ar" a intervenção realizada ${ }^{724}$. Conforme o relato:

\begin{abstract}
Um dia eu fui posar na casa do Fernandes Ursulino de Freitas e quando eu saí no terreiro ele enxergou que a minha filha tava doente, sofrendo de quaieira. Ela tava querendo virar, mas ele não deixou. Quando a quaieira vira, encolhe uma perna, dá desinteria, vômito. Ele falou pra ela ficar sentada na porta da casa, que ele mandava o benzimento pelo ar. Porque é uma força oculta o benzimento e ele tinha a revelação da doença que a pessoa tava sofrendo. Deu certo, ela sarou e não precisou de remédio. Uma outra vez ele benzeu ao vivo, nós levamos ela lá ${ }^{725}$.
\end{abstract}

Além de benzer, fazer orações e garrafadas, os curandores podiam utilizar outros métodos, como esfregar o corpo do doente com ervas ou banhá-los em águas especiais. Esse pode ser mais um ponto de contato com a África Central. De acordo com Sweet, "[...] os banhos com ervas eram utilizados na África Central com o objectivo de curar doenças" ${ }^{\prime 26}$.

O curandor do Médio Ribeira também podia tirar do corpo do enfermo a causa do mal - por exemplo, podia fazer o enfermo vomitar "cabelos". Daniela Buono Calainho frisou que, entre os povos bantos, unhas e cabelos representavam emanações do espírito, por isso, eram tidos como curativos, mas também como provocadores de malefícios $^{727}$.

Outro método de cura empregado pelos curandores do Médio Ribeira era a descoberta de malefícios enterrados, como panelas e caixões de defunto ${ }^{728}$. Conforme Laura de Mello e Souza, "[...] provocar malefícios por meio de feitiços enterrados era procedimento comum no Brasil colônia"729 e os feitiços enterrados concentravam forças maléficas de extrema virulência ${ }^{730}$. Sweet relatou um fato ocorrido na Bahia, em 1646, no qual um curandeiro negro acusou uma cativa de ter

\footnotetext{
${ }^{724}$ Conforme Cavazzi, os centro-africanos "[...] acreditavam que a alma pode avisar os vivos da sua presença, ou suavemente, com um leve sopro de vento, ou furiosamente, com o trovão da tempestade". (MONTECÚCCOLO, 1965, p. 186).

${ }^{725}$ Relato incluído no Inventário cultural de quilombos do Vale do Ribeira. (ANDRADE; TATTO, 2013, p. 168).

${ }^{726}$ SWEET, 2007, p. 189.

${ }^{727}$ CALAINHO, Daniela Buono. Metrópole das Mandingas: religiosidade negra e inquisição portuguesa no Antigo Regime. Garamond, 2008, p. 83.

${ }^{728}$ CARVALHO, Maria Celina. Negros do Ribeira: Feitiçaria, curandores e catolicismo popular. $3^{a}$ Prêmio Territórios Quilombolas. Brasília: Ministério do Desenvolvimento Agrário, 2011, p. 438.

${ }^{729}$ SOUZA, 2009, p. 172.

${ }^{730}$ Ibid., p. 173.

218
} 
enterrado embrulhos que continham unhas, cabelos e pós, para fazer a proprietária dela adoecer ${ }^{731}$. Fabiana Schleumer também relatou casos envolvendo o enterro de malefícios. Ela citou o caso das escravizadas Joana (nascida no Brasil) e Isabel (nascida no Congo). Elas viviam na cidade de São Paulo em meados do século XVIII e, em 1759, foram acusadas de provocar malefícios. Elas foram presas e sofreram castigos físicos para que contassem os detalhes das suas práticas. Por fim, as escravizadas identificaram o local onde tinham enterrado o malefício - composto por várias raízes, um pedaço de gengibre e um osso pequeno ${ }^{732}$.

O enterro de malefícios pode ser compreendido segundo o paradigma da kalunga. Para os centro-africanos, o mundo debaixo era identificado com o "outro mundo" (onde existiam os ancestrais, antepassados e espíritos diversos). Portanto, enterrar o malefício era uma forma de potencializá-lo, pois passaria a contar com os poderes dos seres do "outro mundo". Algo nocivo, por exemplo, um malefício, ao ser enterrado, tornava-se mais danoso; no entanto, o oposto também poderia ocorrer ou seja, algo benéfico aumentava sua capacidade de fazer o bem ao ser enterrado $^{733}$. Este era o caso da bebida guiné, vista como capaz de "fechar o corpo". Guiné é uma planta (Petiveria tetrandra) e a beberagem era feita com a sua raiz - acrescida de aguardente, arruda, alho, raspagem de chifre de boi, entre outros ingredientes. Muitas vezes, fazia parte do preparo deixar a beberagem enterrada por um dia. Dessa forma, ela entrava em contato com o mundo debaixo e seu poder de proteger da desventura era potencializado.

Embora não exista consenso, ou seja, algumas pessoas falaram que isso não acontecia, alguns quilombolas destacaram a ocorrência de outro método de adivinhação e cura, a possessão ${ }^{734}$. Segundo alguns relatos, quando o espírito

\footnotetext{
${ }^{731}$ SWEET, op. cit., p. 197.

${ }^{732}$ SCHLEUMER, Fabiana. Bexigas, Curas e Calundus: caminhos da morte entre escravos em São Paulo e seus arredores (Século XVIIII). 2005. Tese (Doutorado em História) - Faculdade de Filosofia, Letras e Ciências Humanas da Universidade de São Paulo, São Paulo, 2005, p. 203-205.

${ }^{733}$ Laura de Mello e Souza citou um caso que envolvia o enterro de bolsas de mandinga e o aumento do seu poder. Os escravizados envolvidos foram sentenciados, em 1731, pelo Santo Ofício: "José Francisco Pereira e José Francisco Pedroso, eram naturais de Judá, Costa da Mina, e tinham morado no Brasil durante algum tempo, lá recebendo o batismo e a crisma. Em Portugal, haviam também se envolvido no comércio de bolsas de mandinga, preparando-as ritualisticamente, enterrando-as de noite, em encruzilhadas, para terem mais poder". (SOUZA, Laura de Mello. Inferno Atlântico: demonologia e colonização século XVI-XVIII. São Paulo: Companhia das Letras, 2001, p. 170).

${ }_{734}$ Pode ser que a possessão, em alguns locais, seja algo muito recuado no tempo e, por isso, não faça mais parte da memória do grupo. Também pode ser que algumas pessoas tenham dificuldade em falar sobre o tema por causa do preconceito contra a religiosidade mediúnica existente no Brasil. 
baixava, a pessoa que o recebia se contorcia, mudava de cor e falava com a voz alterada. Em seguida, ela olhava para a garrafa e fazia as revelações. Um quilombola contou que, quando o espírito baixava, até as garrafas tremiam.

Sweet ressaltou a importância da possessão na África Central. Conforme esse autor:

[...] a possessão de seres humanos, normalmente por espíritos de antepassados, era uma forma de adivinhação mais directa e espectacular. Em vez de servir de mediador em rituais públicos que eram interpretados pelo próprio adivinho e pelos seus clientes, o adivinho possuído recebia literalmente um espírito do outro mundo, dando-lhe uma forma humana e permitindo ao cliente conversar directamente com o mundo espiritual. A partir do momento em que o espírito entrava no corpo do adivinho/ médium, até a própria voz do médium se tornava a voz do espírito. Este podia então ser questionado e envolvido numa conversa, sendo que o corpo do médium servia meramente de meio de comunicação. Desta forma, os clientes podiam saber mais sobre as origens do seu problema e sobre os remédios necessários às sua resolução ${ }^{735}$.

Cavazzi testemunhou muitos casos de possessão na África Central. A possessão era conduzida por "sacerdotes, chamados 'xinguila'"736. De acordo com Cavazzi, era crença generalizada nas regiões do Dongo, Angola e Matamba que "[...] o espírito de qualquer defunto entra, quando lhe aprouver, no corpo do xinguila, manifestando os seus desejos e as suas necessidades" ${ }^{737}$. Cavazzi explicou que xinguila significava "[...] adivinho possuído por um espírito que fala pela sua boca". Ele ressaltou que os xinguilas eram muito temidos e o respeito baseava-se na "crença nos oráculos", ou seja, ele deveria ser obedecido porque "[...] a função é promovida não pelo capricho, mas pelo impulso interior do espírito consultado"738.

Muitos autores destacaram a ocorrência de casos de possessão no Brasil. Sweet afirmou que, durante o período colonial, as manifestações centro-africanas de mediação espírita eram frequentes. Ele ressaltou que, entre 1685 e 1740, aumentou, acentuadamente, o número de documentos com menção a casos de possessão. Por exemplo, há referência à possessão em processos da Inquisição, em cartas de missionários, na poesia popular e na literatura. Sweet sublinhou que, no Brasil, os rituais de adivinhação que envolviam possessão eram chamados, frequentemente,

\footnotetext{
${ }^{735}$ SWEET, 2007, op. cit., p. 167.

${ }^{736}$ MONTECÚCCOLO, 1965, p. 186.

${ }^{737}$ Ibid., p. 186.

${ }^{738}$ Ibid., p. 204. 
de "calundu". A origem do termo era a palavra "quilundu" que, em Angola, era o nome genérico para qualquer espírito que possuísse os vivos ${ }^{739}$. Segundo Laura de Mello e Souza, a primeira descrição mais detalhada de um calundu está contida na obra de Nuno Marques Pereira. O hospedeiro explicou o significado do termo "calundus" ao Peregrino da seguinte forma:

São uns folguedos, ou adivinhações (me disse o morador), que dizem estes pretos que costumam fazer nas suas terras, e quando se acham juntos, também usam dele cá, para saberem várias coisas, como as doenças de que procedem, e para adivinharem algumas coisas perdidas; e também para terem ventura em suas caçadas, e lavouras; e outras muitas coisas ${ }^{740}$.

Muitos pesquisadores se debruçaram sobre as práticas de calundu. No entanto, conforme Laura de Mello e Souza, o termo recobriu práticas diversas, algumas parecidas, outras distantes ${ }^{741}$. Dessa forma, propôs que o termo calundu fosse tomado "[...] antes como constelação de práticas variadas do que como rito acabado ou bem definido"742. No Vale do Ribeira, não ouvimos a palavra "calundu", mas relatos apontam para a ocorrência da possessão, fenômeno amplamente verificado na África Central e em várias partes do Brasil. A possessão também pode ser inscrita no paradigma da kalunga, pois é uma forma de comunicação com o "outro mundo". Os espíritos cruzavam a linha de divisão entre o "outro mundo" e "este mundo" e, diretamente, revelavam aos vivos o que deveria ser feito para se livrarem da desventura e obterem ventura.

Segundo alguns relatos coletados nas comunidades negras de Eldorado e Iporanga, um dos espíritos que baixava nos ritos de adivinhação e cura chamava-se "Frederico Pé de Ferro"743. Conforme já abordado, para os centro-africanos, o ferro estava associado ao poder. Portanto, se as entidades do "outro mundo" já eram poderosas, "Frederico Pé de Ferro" era ainda mais. Ele era visto com uma entidade com muita capacidade de intervenção no mundo temporal. A sua potência podia ser intuída pelo estrondo que provocava no momento em que baixava, ou seja, o barulho muito alto apontava para seu elevado poder.

\footnotetext{
${ }^{739}$ SWEET, 2007, p. 171-172.

740 PEREIRA, Nunos Marques. Compêndio narrativo do Peregrino da América. 6 ed. Rio de Janeiro: Publicação da Academia Brasileira, 1939, v.l, p. 123.

${ }^{741}$ SOUZA, 2005, p. 316.

742 lbid., p. 298.

${ }^{743}$ Algumas pessoas chamam de "Frederico Pau de Ferro". 
"Frederico Pé de Ferro" não baixava apenas nos curandores, bem como outros espíritos faziam o mesmo - não eram só os curandores que recebiam os espíritos. Segundo alguns relatos, as pessoas que recebiam os espíritos ficavam muito fortes. A associação entre possessão e força foi muito ressaltada, simbolicamente, era a força do "outro mundo". A pessoa que recebia o espírito ficava capaz de bater em muitas pessoas e, se precisasse ser contida, era necessário o apoio de muitos. Geralmente, após a possessão, aquele que incorporava ficava exausto.

Algumas pessoas relacionaram os espíritos e as águas. Segundo alguns relatos, algumas pessoas, ao receber os espíritos, queriam se lançar ao rio algumas conseguiam fazer isso e, por muito tempo, ficavam debaixo d'água. Se pensarmos no cosmograma congo, jogar-se no rio representava cruzar a kalunga e realizar a viagem de volta ao "outro mundo". Conforme visto anteriormente, o Rio Ribeira era cheio de entidades - os bissimbilsimbilkianda - ou seja, os ancestrais, os antepassados, os espíritos d'água. Portanto, simbolicamente, fazia sentido que o espírito que baixava quisesse se lançar na kalunga e se juntar aos seus pares.

Na Comunidade Remanescente de Quilombo de Praia Grande (Iporanga), há uma história que associa força e travessia das águas. Trata-se da história de um senhor já falecido. O nome dele era Domingos, mas ele era conhecido como "Coisa Ruim"744. Muitas pessoas disseram que ele era muito forte e tinha muita habilidade para navegar. Embora ninguém tenha falado em possessão, há um relato no Relatório Técnico Científico da Comunidade Remanescente de Quilombo de Praia Grande que pode indicar que a força de Domingos era vista como proveniente de um espírito. Segundo o informante, Domingos Coisa Ruim atravessava cachoeiras e correntezas que ninguém conseguia. Ao citar um diálogo entre o Domingos Coisa Ruim e o filho, este falou: "Só mesmo assim pra você tentar cruzar, porque sem o um você não passava nessa cachoeira" ${ }^{145}$ (grifo nosso). Ou seja, o "um" deveria ser um espírito, que vivia nas águas.

Quilombolas de Praia Grande também relataram a existência de outro ser que vivia nas águas - o Pai Corimba. Corimba era o sobrenome de uma das primeiras

\footnotetext{
${ }_{744}^{74}$ A própria forma como era chamado já fazia menção a um espírito malfazejo ou ao diabo.

${ }^{745}$ INSTITUTO DE TERRAS DO ESTADO DE SÃO PAULO, 2003. p. 35. 
famílias que ocuparam o atual território da Comunidade Remanescente de Quilombo da Praia Grande. No século XIX, o sobrenome Corimba foi substituído por Pereira de Souza e é esse o sobrenome de muitos moradores da referida comunidade. No entanto, mesmo com a adoção do novo sobrenome, o nome Corimba continua sendo atribuído às pessoas da família. Por exemplo, atualmente, o sr. Antonio Marmo Pereira de Souza é conhecido como Antonio Corimba. Em 1909, Pedro Pereira de Souza aparecia nos registros da Paróquia de Iporanga como Pedro Corimba $^{746}$.

Assim como negros d'água, o Pai Corimba tem origem no mundo das águas, no mundo de baixo. Ser chamado de Pai parece ser uma clara referência ao seu papel de ancestral da comunidade de Praia Grande, oriundo de um mundo além das águas. Assim, simbolicamente, originava-se do reino dos mortos e, concretamente, da África. Situada nas proximidades da foz do rio Cuanza, em 1563, a região de Corimba era disputa pelos chefes do Congo e do Dongo ${ }^{747}$. Além de integrada ao comércio atlântico, devia ser importante do ponto de vista simbólico, pois, segundo Cavazzi, foi onde nasceu Luqueni, o primeiro chefe do Congo. De acordo com ele, Luqueni "[...] conquistou o vasto reino chamado 'Congo', divido hoje em três: Angola, Matamba e Congo propriamente dito"748.

Assim, as águas do Rio Ribeira eram cruzadas pelo Pai Corimba, pelos negros d'água, pelos espíritos que baixavam nas pessoas e por outros espíritos d'água.

\footnotetext{
${ }^{746}$ Ibid., p. 31.

${ }^{747}$ HEINTZ, 2007, p. 184.

${ }^{748}$ MONTECÚCCOLO, 1965, livro segundo, p. 231. 


\section{4 As águas, os Espíritos e o Catolicismo}

Alguns curandores do Médio Ribeira inseriam uma cruz nas garrafas utilizadas nos ritos de adivinhação e cura. Dessa forma, além das águas, o rito passava a contar com uma cruz - o maior símbolo do catolicismo. O rito descrito (garrafa com água e cruz) parece semelhante ao praticado pelo curador de feitiço Ignacio, o rosário nas águas ferventes. Assim, curandores do Médio Ribeira e o curador de feitiço Ignacio realizavam ritos de adivinhação e cura, nos quais havia a presença das águas e de um símbolo católico. Da mesma forma que em Iguape, a cruz na garrafa dos curandores do Médio Ribeira parece sinalizar para a presença de crenças centro-africanas e católicas num mesmo rito.

A presença das águas (kalunga) nos ritos de adivinhação e cura era vista como uma forma de facilitar a comunicação com o "outro mundo". Dessa forma, o rito conduzido com a cruz inserida numa garrafa com água ecoa crenças centroafricanas. Quanto à presença da cruz, ela podia ser vista como a representação do "cosmograma congo" ou como um minkisi (receptáculos do poder dos espíritos da terra e das águas), lembrando que, na África Central, cruzes foram vistas como minkisi e utilizadas em ritos de adivinhação e cura. No entanto, parece mais provável que a cruz inserida na garrafa dos "curandores" do Médio Ribeira tenha sido vista como a cruz católica.

Conforme já abordado, o clero de Xiririca dedicou-se à propagação da fé católica e preocupou-se em incluir os negros no mundo cristão. O clero se empenhou em administrar os sacramentos, especialmente o batismo e a desobriga quaresmal. Muitos senhores também contribuíram para a evangelização dos escravizados. Desde o século XVIII, os negros organizavam festejos em louvor a São Benedito e a Nossa Senhora do Rosário. A região de Ivaporunduva assumiu papel importante no tocante à difusão do catolicismo. Os negros arcaram com os custos da construção de uma capela na localidade, a qual serviu de sede para a irmandade que fundaram, a Irmandade de Nossa Senhora do Rosário dos Homens Pretos. Em grande parte devido à atuação dessa Irmandade, na região do Médio Ribeira desenvolveu-se um catolicismo fundado em torno das devoções aos santos. 
Nossa Senhora do Rosário, São João Baptista, Santo Antonio de Lisboa, São Benedito, Senhor Bom Jesus de Iguape, além de outros santos, foram muito festejados, louvados e lembrados nos momentos de infortúnio. Algumas festas típicas do catolicismo popular, como a festa do Divino Espírito Santo, a Recomendação das Almas, a Romaria de São Gonçalo e a Festa da Santa Cruz, congregavam muitas pessoas. Elas ocupavam papel importante na vida social e no mundo cultural e religioso dos seus praticantes.

Africanos e seus descendentes elaboraram e vivenciaram as práticas católicas conforme suas visões de mundo e seus interesses. A presença da cruz no rito dos curandores demonstra a importância do catolicismo no Médio Ribeira. A cruz católica pode ter sido vista como um meio de pontecializar a comunicação com o "outro mundo". Seja lá como a participação da cruz foi entendida no rito, o fato é que os curandores, ao praticarem essa forma de adivinhação, integraram o mais importante símbolo do catolicismo a um rito enraizado em crenças centro-africanas.

A Bica Canhambora pode ser vista como outro exemplo do encontro de crenças centro-africanas e católicas. Conforme exposto anteriormente, a bica localiza-se numa área de confluência de córregos. Também está associada ao mundo dos mortos. Há uma cova visível e dizem que algumas pessoas foram enterradas nas proximidades. De acordo com alguns relatos, espíritos rondavam o local. Também diziam que as águas da bica eram milagrosas. Assim, temos três elementos: mortos, águas e cura. Se usarmos um prisma centro-africano, podemos traduzir os três elementos da seguinte forma: "outro mundo", kalunga e fonte de ventura. Pode ser que as águas tenham sido vistas como milagrosas porque possibilitavam acesso ao poder do mundo dos mortos, fonte da ventura. Portanto, crenças centro-africanas parecem ter alicerçado a forma como a bica e as suas águas foram vistas. Porém, também havia uma cruz católica. Assim, crenças católicas também faziam parte do universo cultural das pessoas que enterravam os mortos e utilizavam as águas da bica.

Conforme alguns informantes, não só as águas da Bica Canhambora, mas as águas correntes eram utilizadas em processos de cura simples, ou seja, realizadas sem o auxílio de um curandor. As pessoas adoentadas iam a um local com água corrente - cachoeira, córrego ou bica -, pegavam um pouco de água e a benziam. $\mathrm{O}$ 
benzimento era feito em nome de algum santo ou em nome da santíssima trindade ("em nome do pai, do filho e do espírito santo"). Depois, bebiam a água. Portanto, o rito de cura com a presença das águas (kalunga) sugere que o rito foi influenciado por crenças centroafricanas. No entanto, também estavam presentes elementos do mundo católico (santos e santíssima trindade). Portanto, o rito parece ter raízes em crenças católicas e centro-africanas.

Outro exemplo de encontro de visões de mundo e de culturas ocorreu no Alto Ribeira, na Comunidade Remanescente de Quilombo do Cangume ${ }^{749}$. Há muitos anos, durante a Festa de Santa Cruz, várias pessoas foram possuídas por espíritos. Assim, ao mesmo tempo em que a cruz, símbolo máximo do catolicismo, estava sendo celebrada, ocorria a forma centro-africana mais direta de comunicação com o "outro mundo", a possessão espírita.

Seja pelo elevado número de pessoas possuídas, seja pela dificuldade de "despossessão" ou por qualquer outro motivo, algumas pessoas buscaram o auxílio de um kardecista francês (ou descendente de francês) ${ }^{750}$ que tinha se estabelecido no município. O médium conseguiu solucionar a situação e, em seguida, a comunidade se converteu ao kardecismo. O fato foi narrado no Relatório Técnico Científico de Cangume da seguinte forma:

\begin{abstract}
Em meados da década de 1920, durante a tradicional festa da Santa Cruz, realizada nos primeiros dias de maio por um festeiro da própria comunidade, seus moradores foram surpreendidos por uma situação de transe coletivo, no qual várias das senhoras e senhores mais velhos pareciam tomados por espíritos, caindo inconscientes ou gritando e chorando simultaneamente. Sem saberem lidar com a situação, os moradores foram buscar ajuda no bairro vizinho, o bairro dos Boavas, onde morava um médium conhecido por seu dom para a despossessão. De fato, o médium conseguiu fazer com que as pessoas saíssem do transe, e o evento marcou tão profundamente a comunidade, que resultou em uma conversão, também coletiva, ao kardecismo. ${ }^{751}$
\end{abstract}

Até o momento da conversão ao kardecismo, os moradores do Cangume eram católicos - cultuavam os santos e realizavam as celebrações típicas do catolicismo, como a Recomendação das Almas. Os curandores do Médio Ribeira

\footnotetext{
${ }^{749}$ A Comunidade Remanescente de Quilombo de Cangume localiza-se em Itaoca, município vizinho a lporanga

${ }^{750}$ A informação que esse médium era kardecista foi obtida com a antropóloga Patrícia Scalli dos Santos.

${ }^{751}$ INSTITUTO DE TERRAS DO ESTADO DE SÃO PAULO, 2003, p. 76. 
também realizavam práticas católicas, pois louvavam e festejavam os santos, rezavam o terço, benziam, participavam da Festa do Divino, da Recomendação das Almas, da Romaria de São Gonçalo, entoavam "excelências" nos enterros, iam a Iguape pagar promessa ao Senhor Bom Jesus, abençoavam as garrafadas com orações $^{752}$, entre outras práticas.

Rito de adivinhação e cura com rosário e cruz? Possessão espirita e culto aos santos? Oração e Garrafada? Transe coletivo na Festa da Santa Cruz? Que catolicismo é esse?

Esse era o catolicismo praticado pelas populações negras do Vale do Ribeira, o qual resultou de uma apreensão africana da religião imposta. Desse modo, a religião resultante estava enraizada em crenças e tradições africanas. Esse catolicismo pode ser interpretado sob o prisma proposto por Marina de Mello e Souza, ou seja, abordando a "[...] religiosidade das comunidades afrodescendentes, tomando como foco não os chamados cultos afro-brasileiros e sim o catolicismo exercido por algumas dessas comunidades" ${ }^{753}$.

Isso representava um problema?

Para algumas pessoas, sim. Para Luiz Alvares, conforme analisado, o encontro de crenças católicas e africanas significou uma "profanação" e ele utilizou a maior instância do poder local - a Câmara da Vila de Iguape - para eliminar as práticas dos curadores negros. Anos depois, as práticas religiosas deixaram de ser um assunto do Estado, o que não aboliu o preconceito e o desdém. Por exemplo, Young, nos primeiros anos da República, disse que "infelizmente" ainda existiam curandeiros em Iguape. No começo do século XX, o pesquisador Krug também não viu com bons olhos o catolicismo popular. Ele viajou pelo interior do Estado de São Paulo e ficou impressionado com a diferença entre o catolicismo oficial (romano) e o catolicismo praticado pelas populações rurais:

Em todo o caso tenho motivos poderosos para poder afirmar positivamente, que se quizesse organizar de novo uma crença católica conforme as opiniões correntes dos nossos caboclos, a actual, passaria por muitas modificações, elles, os caboclos, haviam de incluir na sua reorganização

\footnotetext{
${ }^{752}$ A semana santa era considerada um bom momento para o preparo das garrafadas.

${ }^{753}$ SOUZA, Marina de Mello. Catolicismo Negro no Brasil. Afro-Asia, Salvador, n 28, 2002, p. 126. 
uma porção de feitiçarias, de necromancia, de capnomancia, etc. ${ }^{754}$

E, foi justamente esse catolicismo popular, assentado em crenças e tradições africanas, que foi combatido ao longo do processo de romanização. Segundo Ferreira, no Brasil, a romanização iniciou-se na segunda metade do século XIX e intensificou-se após a proclamação da República e a separação da Igreja do $E^{E}$ stado $^{755}$. O objetivo era a subordinação da Igreja Católica do Brasil às diretrizes e interesses romanos. Assim, iniciou-se uma luta contra o catolicismo popular, cujo poder religioso concentrava-se nas mãos dos leigos, por meio da subordinação das irmandades ao clero oficial e das restrições às práticas do catolicismo popular, como as ladainhas, os terços e outras rezas. Desta forma, procurava-se fortalecer o clero oficial e, assim, europeizar e romanizar o catolicismo brasileiro ${ }^{756}$. Conforme Ferreira: "Limitar a autonomia do catolicismo popular, certamente, se constituiu numa das maiores preocupações da hierarquia eclesiástica no processo de romanização"757.

O catolicismo popular foi sendo paulatinamente desmantelado ao longo do processo de romanização. Assim, tanto as manifestações típicas do catolicismo popular quanto as atividades dos curandeiros diminuíram acentuadamente. $\mathrm{O}$ catolicismo popular foi substituído por uma versão mais romanizada. No entanto, em alguns locais, como no Cangume, o desfecho foi diferente. O conjunto de crenças católicas e centro-africanas afluiu para o kardecismo.

\footnotetext{
${ }^{754}$ KRUG Edmundo. A superstição paulistana. Revista do Instituto Histórico e Geográfico do Estado de São Paulo, 1910, p. 6.

${ }^{755}$ FERREIRA, Lúcia de Fátima Guerra. Igreja e Romanização: a implantação da diocese da Paraíba. 1994. Tese (Doutorado em História) - Faculdade de Filosofia, Letras e Ciências Humanas da Universidade de São Paulo, São Paulo, 1994, p. 14.

${ }^{756}$ Ibid., p. 35.

${ }^{757}$ Ibid., p. 35. 


\section{Capítulo 8 - As Águas - Circularidade e fronteira no Mundo Atlântico}

\subsection{As Águas e os Ritos de Adivinhação}

Em várias partes do Império Português, especialistas em práticas mágicoreligiosas conduziam ritos de adivinhação nos quais as águas ocupavam papel de destaque. Em Portugal, o método de adivinhação baseado na decifração das águas foi chamado de hidromância. Conforme Bethencourt, a "[...] água, pela sua fluidez e transparência recebe na sua superfície todas as figuras, é um elemento especialmente usado para a prática da adivinhação (hidromância), facto que não é estranho à sua imagem de agente de metamorfoses"

De forma geral, o método consistia no lançamento de elementos simbolicamente valorizados - chumbo, estanho, ovos, gotas de azeite, grãos de cevada, sal - num recipiente (tigela, alguidar) com água. Os elementos misturados na água assumiam uma forma variada, a qual era interpretada ${ }^{759}$. Francisco Bethencourt discorreu sobre os elementos lançados. Quanto ao azeite, o "[...] óleo de oliva simboliza a prosperidade e o espírito divino, surgindo na unção dos reis de Israel e, na tradição cristão, nos ritos de baptismo e morte" ${ }^{760}$. Quanto ao ovo, representa "o símbolo universal do nascimento, da génese do mundo, da totalidade" e, por isso, foi "profusamente referido na prática de hidromância ${ }^{761}$. Quanto ao sal, "[...] como resulta da evaporação da água do mar, simboliza a transmutação física. A sua utilização nos alimentos para a conservação e o tempero é um factor suplementar que valoriza a sua imagem de equilíbrio dos componentes, sendo

${ }^{758}$ BETHENCOURT, Francisco. O imaginário da magia: feiticeiras, saludadores e nigromantes no Século XVI. Lisboa: Centro de Estudos de História e Cultura Portuguesa, 1987, p. 127.

759 lbid., p. 37.

760 lbid., p. 127.

761 Ibid., p. 128. 
empregue na hidromância" ${ }^{762}$. O sal também foi muito utilizado em "práticas de bem querença", pois "[...] era tido como uma substância de grande virtude para inclinar os sentimentos e as vontades" ${ }^{\text {763. }}$.

As ordenações manuelinas classificaram como delito as práticas de adivinhação que utilizavam água, definidas como uma prática de feitiçaria ${ }^{764}$. O índice tridentino proibiu os livros de hidromância, considerada com uma das "artes mágicas". Outras eram a geomância, a aeromância, a piromância, a onomância, a quiromância, a nigromância, as sortes, as feitiçarias, os agouros e os encantamentos $^{765}$. No entanto, segundo Bethencourt, a repressão inquisitorial foi relativamente branda "face à magia ilícita". A Inquisição em Portugal, no século XVI, preocupou-se em afirmar-se contra o maometanismo e o judaísmo. A política da Igreja evitou dissensões profundas no seio dos cristãos velhos e assumiu um relativo compromisso "[...] com as formas desviadas de praticar e de sentir a religião"766. De acordo com Bethencourt:

[...] os resultados desta política de compromisso (relativo) com a religiosidade popular, de repressão branda sobre a magia ilícita e as práticas 'supersticiosas", consistem, fundamentalmente, na perpetuação da visão mágica do mundo, tanto entre as camadas populares como entre o baixo clero ${ }^{767}$.

Desse modo, a maioria dos portugueses que vieram para o Brasil praticava um catolicismo distante da ortodoxia.

Bethencourt pesquisou as práticas religiosas observadas em Portugal no século XVI. Daniela Buono Calainho pesquisou as práticas religiosas realizadas em Portugal ao longo de quatro séculos. Ela destacou que, em 1552, os negros representavam quase dez por cento da população de Lisboa ${ }^{768}$. A visão de mundo deles também contribuiu com o catolicismo. Conforme a pesquisadora: "[...] 0 catolicismo português era um amálgama de crenças e práticas envolvendo curandeiros negros e brancos e padres exorcistas, distante, pois, da ortodoxia das

\footnotetext{
${ }^{762}$ BETHENCOURT, 1987 , p. 128.

${ }^{763}$ Ibid., p. 80.

${ }^{764}$ Ibid., p. 228.

${ }^{765}$ Ibid., p. 233.

${ }^{766}$ Ibid., p. 247.

${ }^{767}$ Ibid., p. 260.

${ }^{768}$ CALAINHO, 2008, 16-17. 
hostes hierarquicamente superiores da Igreja"769. Daniela Calainho destacou a circularidade de saberes entre africanos residentes em Portugal, a população lusoafricana e os brancos reinois ${ }^{770}$. Podemos buscar na obra de Francisco Bethencourt um bom exemplo da circulação de saberes entre portugueses e africanos. Ele citou o caso das portuguesas Madalena Correia e a filha Camila. Elas utilizavam uma bola de cristal como instrumento de adivinhação na Igreja de Nossa Senhora dos Remédios, junto a Évora. Segundo testemunhos "[...] a conta de cristal teria sido trazida à casa de Nossa Senhora por umas mulheres africanas" ${ }^{771}$.

Além da circulação em Portugal, Daniela Calainho ressaltou que também existiu uma notável circulação de saberes "[...] entre os negros moradores no Reino e estes e os do Brasil" ${ }^{772}$. Dessa forma, as manifestações culturais no Império português apresentavam elevado grau de complexidade ${ }^{773}$.

Sweet assinalou a circularidade de saberes relacionados aos ritos de adivinhação entre africanos de diferentes procedências. De acordo com o pesquisador, os africanos da África Central e da Costa da Mina compartilhavam um conjunto de crenças acerca da importância da adivinhação. Em alguns casos, os ritos eram idênticos ${ }^{774}$. Quanto à Costa da Mina, ele destacou que "[...] a forma mais comum de adivinhação envolvia o recurso a uma panela com água [...]" e também que existia a crença de "[...] que os espíritos podiam ser invocados para entrar na água e proferir mensagens" ${ }^{775}$. Sweet citou vários casos de africanos da Costa de Mina que conduziam ritos de adivinhação no Brasil. Por exemplo, José Mina, em 1734, nos arredores do Rio de Janeiro, colocou um prato com água sobre um círculo que desenhara no chão. Em seguida, olhou para a superfície da água e "[...] fez várias perguntas ao prato. Após a invocação, pôde escutar uma voz fraca, que deu as respostas às perguntas de José" ${ }^{776}$.

Sweet também citou exemplos relacionados aos centro-africanos. Por exemplo, em 1721, Domingos João Pereira, africano oriundo de Angola, foi

\footnotetext{
${ }^{769}$ CALAINHO, 2008, p. 157.

${ }^{770}$ Ibid., p. 94.

${ }^{771}$ BETHENCOURT, 1987, p. 46.

${ }^{772}$ CALAINHO, op. cit., p. 157.

${ }^{773}$ Ibid., p. 263.

${ }^{774}$ SWEET, 2007, p. 159.

${ }^{775}$ Ibid., p. 157.

${ }^{776}$ Ibid., p. 157.

231
} 
procurado por Bárbara Morais, mulher branca, residente em Olinda. Bárbara suspeitava que o marido estava sendo "vítima de feitiço". Domingos "[...] preparou uma dança com três garrafas: agarrando uma, dançou com ela e mostrou a garrafa suspensa no ar". Dentro da garrafa, apareceu o homem "que tinha feito os feitiços" um negro idoso ${ }^{777}$. Ao explicar o rito, Sweet enfatizou a presença das garrafas:

As garrafas com as quais Domingos 'dançou' faziam parte da cosmologia do Congo. Vários observadores do século XVIII notaram que os Congoleses e os seus descendentes na diáspora recorriam a garrafas para enganar e aprisionar espíritos malévolos. Muitas dessas garrafas eram penduradas em árvores, servindo para proteger as casas e as plantações da influência perniciosa de espíritos. Domingos utilizou as suas garrafas para revelar os espíritos maldosos que estavam na origem da doença do seu cliente ${ }^{778}$

Já abordamos a importância das garrafas para os centro-africanos ao abordar o cemitério da Comunidade Remanescente de Quilombo de Porto Velho ${ }^{779}$. No entanto, acreditamos que, no caso de Domingos, mais importante que o recipiente a garrafa -, era a presença das águas. As águas, como já analisado anteriormente, eram importantes para os centro-africanos porque facilitavam a comunicação com o "outro mundo". Interessante notar que, em muitas práticas adivinhatórias, o recipiente com a água era colocado no chão, ou seja, mais próximo do "mundo debaixo", do "outro mundo". E também, em alguns casos, há menção a "uma voz" saída das águas, a qual pode ser interpretada como uma mensagem proferida por um ser do "outro mundo".

Laura de Mello e Souza destacou a importância das águas nas práticas adivinhatórias realizadas no Brasil, pois "[...] muitas adivinhações utilizavam a água como recurso ritual" ${ }^{780}$. Ela citou vários casos, como o de um adivinhador anônimo de Recife que, por volta do ano de 1728, "[...] foi procurado por Faustino de Abreu, homem pardo que morava na Freguesia da Vargem e que acreditava estar Marciana de tal enfeitiçada. Consultado, o adivinhador mostrou os autores do feitiço num alguidar cheio d'água: apareceram nitidamente, Faustino os reconheceu sem dificuldade" ${ }^{781}$.

\footnotetext{
${ }^{777}$ SWEET, 2007, p. 152-153.

${ }^{778}$ Ibid., p. 153.

${ }^{779}$ Capítulo 6 - item 6.3.

${ }^{780}$ SOUZA, 2009, p. 163.

${ }^{781}$ Ibid., p. 163.

232
} 
O negro José, no século XVIII, em Conceição do Mato Dentro, em Minas Gerais, conduzia ritos de adivinhação colocando um prato de água no chão e, "[...] junto dele, enterrada no chão, uma faca de ponta. Fazia perguntas, 'às quais respondia de junto do prato uma vozinha a modo de chiar de morcegos', esclarecendo sobre as moléstias e achaques 'que cada qual tinha"'782. Um rito semelhante foi conduzido por Domingos Álvares, oriundo da Costa da Mina. No Rio de Janeiro, em meados do século XVIII, ele conduzia ritos nos quais havia uma vasilha d'água com faca de ponta cravada nela. Junto a vasilha, saltava e dançava uma mulher possuída por espírito, a qual Domingos Álvares chamava de "Capitão"783.

Outro exemplo é o da mestiça Maria Barbosa. Nascida no Brasil, a qual fora degredada para Angola. Na outra margem do Atlântico, conduzia ritos de adivinhação e atendia pessoas de elevado prestígio social, como o próprio governador. Conforme Laura de Mello e Souza:

Maria Barbosa, mulata de passado duvidoso, morava na Bahia no início do século XVII. Parece que fora antes degredada para Angola por feitiçaria: uma vez no Brasil, reincidiu no crime. Entre muitas denúncias que the fizeram, veio à baila um episódio antigo: mostrara em um alguidar de água a Manuel de Silveira, governador de Angola, a imagem de sua mulher residente em Portugal. Previra também os anos que duraria seu governo em Angola ${ }^{784}$.

Depois do degredo, Maria Barbosa voltou ao Brasil, onde foi presa. Ela orgulhava-se de conhecer "[...] várias feitiçarias e orações mágicas, uma delas invocando um curioso 'diabo marinho'"'785. Dessa forma, parece que Maria Barbosa invocava os espíritos d'água. Uma das suas orações era a seguinte: "Grande diabo marinho, a ti te entrego este pinho"786.

Assim como Maria Barbosa, as pessoas e os saberes circulavam pelas várias partes do Império Português. No Brasil, os saberes também circulavam: entre os negros procedentes de diferentes regiões da África e entre eles, os portugueses e os indígenas.

\footnotetext{
${ }^{782}$ SOUZA, 2009, p. 166.

${ }^{783}$ Ibid., p. 264.

${ }^{784}$ Ibid., p. 189.

${ }^{785}$ Ibid., p. 337.

${ }^{786}$ Ibid., p. 186. 
Entre as práticas surgidas do encontro entre europeus, africanos e indígenas, Laura de Mello e Souza sublinhou a importância da bolsa de mandinga, também chamada de patuás. A bolsa de mandinga congregava tradições europeias, africanas e indígenas. Muito populares, elas foram usadas de Norte a Sul do Brasil, pelas pessoas das mais diversas camadas sociais ${ }^{787}$. Segundo a pesquisadora, as bolsas de mandinga expressavam a forma mais tipicamente colonial da "feitiçaria" no Brasil. O apogeu do uso ocorreu no século XVIII, ou seja, com a percepção de uma mentalidade colonial, fermentada nos séculos anteriores. De acordo com Laura de Mello e Souza:

\begin{abstract}
Por que, então, o uso de bolsas só se generalizaria no século XVIII? Talvez a resposta esteja mesmo no tempo despendido para a construção de uma prática sincrética de alto significado simbólico. O tempo despendido para generalizar o uso da bolsa de mandinga foi, curiosamente, o mesmo levado pela construção de uma mentalidade colonial: a percepção daquilo que Vilhena batizaria de "viver em colônias" ")
\end{abstract}

No Vale do Ribeira, as bolsas de mandingas também foram usadas. No Médio Ribeira, foram chamadas de patuás e populares até meados do século XX. Abaixo, um exemplo de oração que constava no patuá de uma quilombola do Médio Ribeira. Apontando para a circularidade dos saberes, a oração em louvor a São Jornal parece resultante de contribuições europeias e africanas. Parece que o "rei-ferreiro" africano foi transformado em santo, o São Martelo. Há uma leve sugestão à possessão espírita (a repetição do verbo "tremer") a qual também pode ser uma alusão ao catolicismo, vista a importância do temor a Deus. Por fim, o "tremer" foi associado a um infortúnio do mundo temporal - os surtos de malária que assolavam a região. A influência européia pode ser percebida pela presença dos santos católicos, da passagem da Bíblia referente à crucificação de Jesus e do diabo. As águas e os rios (caminhos andantes), ou seja, a kalunga, também foram lembradas.

Senhor, São Jorná, do campo missá, põe o nome na estrela, corrente a justiça. Senhor São Martelo, que rompe o ferro, na sexta-feira estava Jesus posto na cruz, chegou Pilatos, perguntou: 'do que treme, treme de mim ou treme da cruz: 'Eu não tremo e nem tremeremos, nem maleita teremos'. Caminhos andantes, águas passadas, diabos arrebentados, Bom Jesus, Ave Maria, Amém ${ }^{789}$.

\footnotetext{
${ }^{787}$ SOUZA, 2009, p. 210

${ }^{788}$ Ibid., p. 211

${ }^{789}$ Oração de São Jornal (Jorná), coletada pela pesquisadora Maria Celina, narrada por uma 234
} 


\subsection{As Águas e os Santos}

As águas do mar e do rio também estão relacionadas com o santo mais festejado do Vale do Ribeira, o Senhor Bom Jesus de Iguape.

Segundo o Livro de Tombo de Iguape (1816-1854) ${ }^{790}$, a Imagem do Senhor Bom Jesus estava em um navio português que cruzava o Atlântico em direção a Pernambuco. Porém, no caminho, surgiu um navio de "inimigos infiéis". Para que a Imagem não caísse em mãos inimigas, as pessoas que estavam no navio português lançaram-na ao mar, junto com cera e azeite. Emanando luz, a Imagem flutuou de Norte a Sul. Ao passar pela Ilha de São Sebastião, o vigário da localidade viu (segundo relato ao jesuíta Antonio da Cruz) passar "seis luzes hua noite, cuja luzerna alumiava grande circunferência". Na Praia do Una (divisa de Iguape e Itanhaém), a Imagem foi novamente vista. "Dois indios buçais, e sem conhecimento, e ignorantes da fé" que estavam indo à Vila de Itanhaém, viram "rolando hum vulto com as superfluidades do mar, a que vulgarmente chamão ressácas". Os indígenas levaram o "dito Vulto" para o limite da praia. Eles fizeram uma cova, na qual colocaram o vulto "de pé com o rosto para o nascente". Junto ao vulto, havia uma caixa com cera do reino e umas "bútijas" de azeite doce. Ao retornarem, o vulto estava no mesmo lugar, "[...] mas com o rôsto virado para o pôente, no que fizerão grande reparo pelo terreno deixado para o nascente, e não acharem vestigios, de que pessoa humana o podesse virar".

Os indígenas retornaram ao sítio do seu administrador, Francisco Mesquita, na Praia da Juréia, e contaram o ocorrido. O vizinho de Francisco Mesquita, Jorge Serrano, acompanhado da mulher Anna de Gois, do filho Jorge Serrano e da cunhada Cecilia de Gois, foram até o local descrito pelos índigenas. Eles colocaram a Imagem numa rede e a levaram até o Monte da Juréia. Em seguida, a Imagem foi

quilombola da Comunidade Remanescente de Quilombo de Galvão (Eldorado) no dia 27 de julho de 2002. (CARVALHO, 2011, p.440).

${ }^{790}$ As informações sobre a descoberta da Imagem do Senhor Bom Jesus estão no Livro de Tombo de Iguape (1816-1854), no qual foi transcrito o relato realizado em 1740 pelo Reverendo Christovão da Costa e Oliveira (Vigário da Vara da Villa de Paranaguá) na sua visita à Vila de Iguape. 
transportada para a Barra do Rio Ribeira, onde foi colocada sobre uma pedra. As águas do rio tiraram o "salitre do mar" e a Imagem foi "encarnada de novo". Foi construída uma casa arredondada sobre essa pedra e o local passou a ser chamado de "Fonte do Senhor". Essa pedra passou a crescer "[...] prodigiosamente, e faz já hua grandeza considerável apezar da imensidade de pedaços, ou lascas, que della se tira quazi diariamente"791. No dia 02 de novembro de 1647, a Vila de Iguape testemunhou a "milagroza chegada" da Imagem, a qual foi colocada na Igreja de Nossa Senhora das Neves. Foi vista como um "sobrenatural favor dispensado á esta Villa pela Divina Omnipotencia" para que os moradores da Vila e os romeiros encontrem o "[...] seguro porto, em que tem azillo as suas necessidades temporaes, e espirituaes".

As águas também estão presentes nas devoções ao Senhor Bom Jesus de outros locais. Elas fazem parte da história da descoberta do Senhor Bom Jesus de Pirapora e do Senhor Bom Jesus de Tremembé. Segundo Maria Cecília França:

[...] a água está presente em quase todos os achados milagrosos, quer como transportadora da imagem, quer porque passou a brotar milagrosamente em fonte no local achado ou ainda porque passou a apresentar propriedades terapêuticas por ter servido, por exemplo, para lavar o santo ${ }^{792}$

Em Pirapora, a imagem do Senhor Bom Jesus foi encontrada em cima de uma pedra, no leito do rio Tietê. Quanto ao Bom Jesus de Tremembé, há uma lenda que associa o aparecimento de um misterioso idoso que construiu uma pequena cabana na localidade e que desapareceu repentinamente. Após esse fato, a Imagem do Bom Jesus apareceu. As pessoas tentaram remover os pés do Bom Jesus, no entanto, desse local começou a brotar uma fonte cristalina, cujas águas santificadas curavam todas as enfermidades ${ }^{793}$.

Em lguape, em 1800, uma santa foi descoberta nas águas, nas proximidades da Barra do Rio Ribeira - Nossa Senhora de Guadalupe. Em outras partes do Brasil

\footnotetext{
${ }^{791}$ No começo do século XIX, o vigário de Iguape informou que foi necessário construir uma segunda casa, "por haver cahido a primeira em razão do crescimento da pedra". (Livro de Tombo de Iguape 1816 - 1854).

${ }^{792}$ FRANÇA, M. C. Pequenos Centros Paulistas de Função Religiosa. São Paulo: Universidade de São Paulo - Instituto de Geografia, 1975, p. 70.

${ }^{793}$ FRANÇA, 1975, p. 68-109. 
e da América, muitos santos e santas foram encontrados nas águas. Por exemplo, Nossa Senhora do Rosário saiu do mar após ouvir o som de tambores tocados por negros. A padroeira do Brasil, Nossa Senhora Aparecida, foi encontrada nas águas do rio Paraíba por três pescadores mamelucos (século XVII); a padroeira de Cuba, Nossa Senhora da Caridade, foi achada boiando sobre uma tábua, nas águas do mar, por dois indígenas e um negro (no século XVII); a padroeira do Paraguai, Nossa Senhora de Caacupé, foi encontrada por um indígena quando baixaram as águas de um rio (século XVII); a padroeira da Venezuela, Nossa Senhora Coromoto, apareceu a dois indígenas (Cacique Coromoto e esposa) andando sobre as águas de um rio (século XVII) ${ }^{794}$.

Na narrativa do Senhor Bom Jesus de Iguape, achado nas águas por dois indígenas, e em muitas outras narrativas da descoberta de santos e santas na América, dois pontos se sobressaem: as águas e as populações que os encontraram (negros e indígenas). Assim, podemos ler as narrativas da descoberta dos santos como mitos elaborados na América, na época colonial, portanto, mais precisamente, mitos coloniais.

Quanto às populações que encontraram a Virgem Maria na América, Juliana Beatriz Almeida de Souza ressaltou a elevada frequência de negros e indígenas. Ela também relacionou o fato com a situação colonial. Conforme essa pesquisadora, "Maria, ao falar ora com índios, ora com negros, em uma sociedade colonial com dificuldade para integrá-los, abria um canal para a Igreja chegar àqueles que estavam mais distantes do seu discurso"795. A semelhança física entre algumas Imagens e a população que se desejava atingir (Nossa Senhora Aparecida, negra, e Nossa Senhora de Guadalupe, indígena) também merece ser destacada. A Virgem Maria, mediadora entre os homens e Deus, "[...] na América, identificando-se com a cor de negros, índios e mestiços, fazia-se mediadora cultural entre o universo letrado e o mundo a ser conquistado pela fé católica" ${ }^{796}$.

Portanto, as narrativas da descoberta de santos e santas por negros e indígenas revelam o esforço realizado para integrá-los ao mundo cristão. Laura de

\footnotetext{
${ }^{794}$ SOUZA, Juliana Beatriz Almeida de. Virgem Mestiça: devoção à Nossa Senhora na colonização do Novo Mundo. Tempo, Niterói, v. 6, n. 11, 2001, p. 88-90.

${ }^{795}$ Ibid., p. 90.

${ }^{796}$ Ibid., p. 91.

237
} 
Mello e Souza, em relação ao Brasil, associou religiosidade, situação colonial e a convivência entre os três grupos populacionais. Para a pesquisadora, a característica básica da religiosidade brasileira era "[...] justamente o seu caráter especificamente colonial: branca, negra, indígena, refundiu espiritualidades num todo absolutamente específico e simultaneamente multifacetado" ${ }^{797}$.

Laura de Mello e Souza acrescentou:

\begin{abstract}
Mais ainda: a monarquia - poder temporal -, imiscuindo-se nos negócios do espírito através do Padroado, pautava a evangelização antes por razões de Estado do que pelas da Alma: daí uma Igreja que admitia a escravidão, imprescindível à exploração colonial. A originalidade da cristandade brasileira residiria portanto na mestiçagem, na excentricidade em relação a Roma e no eterno conflito representado pelo fato de, sendo expressão do sistema colonial, ter que engolir a escravidão: uma cristandade marcada pelo estigma da não-fraternidade ${ }^{798}$.
\end{abstract}

Portanto, se a razão para a presença de negros e indígenas no mito da descoberta dos santos e santas é clara, o que dizer das águas? Se a presença é tão recorrente, certamente, existe alguma razão.

Talvez, da mesma forma que os negros d'água do Médio Ribeira, os santos e santas achados nas águas estejam relacionados com a travessia atlântica. Pode ser que a travessia atlântica tenha marcado tão profundamente os povos que a realizaram que passou a ocupar papel importante nas narrativas criadas. Ou seja, ninguém conseguiria passar incólume à travessia. Mesmo para os que não tinham realizado a travessia, existia sempre a possibilidade de fazê-la - voluntariamente ou não.

A travessia do Atlântico/ kalunga foi o rito de passagem que possibilitou o despontar da sociedade colonial. Sociedade que precisou criar seus mitos, como o dos negros d'água e os dos santos e santas achados nas águas. Como já exposto, no mito dos negros d'água, a travessia da kalunga implicou em morte e renascimento. Isso também pode estar presente no mito da descoberta de santos e santas. Simbolicamente, o Senhor Bom Jesus de Iguape e outros santos e santas achados na América morreram e renasceram nas águas. A presença das águas

\footnotetext{
797 SOUZA, 2009, p. 88.

798 Ibid., p. 87-88.

238
} 
revela que a origem dos santos e santas era além-mar, num outro mundo - na Europa. Eles viajaram pelas águas, então, de certa forma, morreram em relação ao local de origem. Apareceram no continente americano e ressuscitaram nesta margem do Atlântico para serem louvados por brancos, negros e indígenas.

No mito do Senhor Bom Jesus de Iguape, a viagem pelas águas é enfatizada - a Imagem estava num navio que cruzava o Oceano e, lançada ao mar, flutuou de norte a sul. Além disso, dois indígenas viram "[...] rolando hum vulto com as superfluidades do mar, a que vulgarmente chamão ressácas". A Imagem foi levada para o limite da praia, ou seja, para a margem americana. Ela foi deixada "de pé com o rosto para o nascente", no entanto, ao retornarem, ela estava no mesmo lugar "mas com o rôsto virado para o pôente". Simbolicamente, o Bom Jesus "virou as costas" para o seu local de origem - a Europa - e passou a pertencer ao mundo americano.

Concomitantemente, o mito reforça a importância das raízes portuguesas para a formação da sociedade colonial. O elemento do mundo europeu central para a formação do mundo americano foi o catolicismo. Presente no mito dos negros d'água, é o elemento mais importante no mito do Bom Jesus. No mar, portugueses católicos chocaram-se com o navio de "inimigos infiéis". Em terras americanas, a imagem foi descoberta por indígenas "ignorantes da fé". Assim, a função do mito era a difusão do catolicismo em terras americanas. Muitos elementos associados às águas cumprem o papel de destacar o caráter milagroso da aparição. Em relação às águas do mar, a imagem cruzava o Atlântico emanando luz. Na beira da praia, a "face" da imagem mudou de direção. Em relação às águas do rio, a imagem foi lavada sobre uma pedra localizada no Rio Ribeira. A imagem recuperou as cores e a pedra, milagrosamente, não parou mais de crescer.

Erguido na beira-mar, o Senhor Bom Jesus serviu como marco delimitador do território americano. O "olhar" de Bom Jesus mirava para a região que deveria ser evangelizada. As águas do Atlântico transformaram-se em contornos do mundo americano e colonial. Um mundo relacionado com o europeu, porém diferenciado. 


\section{Considerações finais}

As águas ocupam papel central na história do Vale do Ribeira. Elas foram atravessadas pelos europeus logo no início da colonização. Da foz do Rio Ribeira, partiam expedições que revolviam suas águas e as dos seus afluentes em busca de metais preciosos. Em 1560, no Alto Ribeira, ocorreu a primeira descoberta de ouro no território português. Nos séculos seguintes, bandeiras continuaram explorando as águas, as areias e os pedregulhos da região. Metais preciosos foram encontrados em cascalhos e corredeiras localizadas no Alto e no Médio Ribeira. Assim, nos séculos XVII e XVIII, foram formados arraiais mineradores. Africanos foram importados para o trabalho nas minas, em uma quantidade relativamente expressiva. No Alto Ribeira, em Apiaí, em 1776, os escravizados compunham 62,9\% da população total. No Médio Ribeira, os arraiais de Iporanga e Ivaporunduva também concentravam ouro e escravizados.

O ouro de aluvião não tardou a exaurir-se e, no final do século XVIII, os arraiais foram extintos. Muitos brancos partiram em busca de oportunidades em regiões mais promissoras. Numerosos escravizados foram abandonados ou alforriados e transformaram-se em camponeses livres. Porém, parcela da população branca permaneceu na região e alocou seus recursos na nova atividade econômica que, a partir do final do século XVIII, começava a ganhar vigor - a produção de arroz. No Baixo e no Médio Ribeira, a lavoura arrozeira propagou-se e garantiu dinamismo econômico à região. No começo do século XIX, produtores de arroz realizaram investimentos expressivos na aquisição de africanos. Em Xiririca, por exemplo, entre 1801 e 1815, os cativos africanos passaram de $9 \%$ para $29 \%$ do total de cativos. Dessa forma, no Médio Ribeira, com o fim dos arraiais mineradores e o início do cultivo do arroz em escala comercial, emergiu uma nova dinâmica populacional. Numa vasta região, passaram a coexistir propriedades com escravizados e núcleos de negros libertos.

O espaço agrícola acompanhava o leito do Rio Ribeira e de seus afluentes. Os solos que ofereciam melhores possibilidades localizavam-se nas áreas inundáveis, pois eram conservados pelas cheias. As águas do rio garantiam a fertilidade dos solos, energia para mover engenhos d'água e local de atraque para 
as canoas. O Rio Ribeira era a estrada natural da região. O domínio de suas águas era a chave do poder do segmento mais abastado da sociedade ribeirense - os comerciantes. Eles possuíam embarcações e, assim, garantiam o trânsito de pessoas e mercadorias.

As águas do Rio Ribeira também são importantes do ponto de vista simbólico. Em suas águas foi lavada a Imagem do Senhor Bom Jesus, o santo mais festejado do Vale. Suas águas eram utilizadas em ritos de adivinhação e cura. Quilombolas do Médio Ribeira afirmam: "Tudo que tem na terra, tem na água". Eles citam os bois d'água, as vacas d'água, os cachorros d'água, os cavalos d'água, entre outros. Também trafegam pelas suas águas os negros d'agua e o Pai Corimba.

As águas, associadas ao sal, também tiveram papel relevante para a história do Ribeira. Elas fazem alusão às águas do mar e à travessia atlântica realizada pelos africanos que aportaram no Vale entre os séculos XVII e XIX. As águas e o sal também estão associados ao sacramento do batismo - rito de entrada no mundo cristão. Portugal, reino missionário, propagou a fé cristã nos dois lados do Atlântico. O Pe. Vieira elaborou metáforas, nas quais o trabalho missionário foi associado às águas e ao sal. Concretamente, o catolicismo estava ligado a esses elementos, pois eles estavam presentes no batismo.

No entanto, no Brasil e na África Centro Ocidental ocorreram recriações. O catolicismo foi apreendido segundo as crenças locais. Por exemplo, na África Centro-Ocidental, provavelmente, o batismo, chamado de "comer sal", foi visto pelos centro-africanos como uma forma de proteção contra o mal e não como uma maneira de purgar o pecado.

No Vale do Ribeira, o clero esforçou-se para a difusão da fé católica e preocupou-se com a inclusão dos africanos e dos seus descendentes no mundo cristão. Porém, o número reduzido de padres e as grandes distâncias dificultavam o trabalho do clero. Os vigários empenhavam-se em administrar os sacramentos, principalmente o batismo e a comunhão, na época da Quaresma. No Vale do Ribeira, assim como em outras partes do Brasil, no período colonial, as irmandades assumiram muitas responsabilidades religiosas e contribuíram significativamente para a difusão do catolicismo. Assim, desenvolveu-se um catolicismo fundado em torno das irmandades, caracterizado pelo culto aos santos. Existiam muitas irmandades em Iguape e Xiririca. As Irmandades de Nossa Senhora do Rosário e de 
São Benedito na Vila de Iguape e a Irmandade de Nossa Senhora do Rosário dos Homens Pretos no Médio Ribeira, compostas por africanos e seus descendentes, foram bastante atuantes.

Os africanos trouxeram consigo suas crenças, assim, o catolicismo foi apreendido segundo lentes próprias. Para os centro-africanos, o universo era formado por dois mundos, o "outro mundo" (antepassados, ancestrais e espíritos diversos) e "este mundo" (vivos), separados pelas águas ("kalunga"). Os dois mundos coexistiam e se interligavam. A fonte do conhecimento e da ventura localizava-se no "outro mundo". Podemos denominar essa maneira de compreender o mundo de paradigma da kalunga.

Os africanos interpretaram o catolicismo conforme os seus próprios pressupostos culturais e o recriaram conforme os seus interesses. Como exemplo, podemos citar os ritos de adivinhação e cura conduzidos por "curadores de feitiço" ou "curandeiros" que utilizavam água e um símbolo católico - a cruz e/ou rosário. Considerando a centralidade das águas no universo cultural centro-africano, muito provavelmente, sua presença era vista como uma forma de potencializar a comunicação com o "outro mundo". Portanto, o rito pode ser inscrito dentro de um conjunto de referências culturais centrado no conceito de kalunga. A presença de um símbolo católico também merece atenção. Ela aponta para a importância do processo de evangelização ocorrido na região do Ribeira. Portanto, o rito estava enraizado em tradições católicas e centro-africanas.

O paradigma da kalunga parece alicerçar muitas elaborações culturais criadas na região do Ribeira. Por exemplo, temos os negros d'água que saem do seu mundo, o mundo debaixo, cruzam a kalunga, e passam a viver na terra. Temos os cemitérios localizados perto das águas, sugerindo que havia intenção de aproximar os mortos da kalunga e, assim, facilitar a comunicação entre o mundo visível e o mundo invisível. Temos a Bica Canhambora, onde estão presentes os mortos e as águas/kalunga, as quais possuem propriedades curativas. Temos os já citados ritos de adivinhação e cura realizados com água/kalunga. Temos as possessões, no qual o "outro mundo" se expressa diretamente através do corpo do condutor do rito.

Essas elaborações culturais ancoradas no paradigma da kalunga podiam ou não estar associadas a símbolos do catolicismo. Por exemplo, os ritos de adivinhação e cura realizados com água podiam ou não conter um símbolo católico 
(rosário ou cruz). Porém, devido à relevância da evangelização, verificamos a presença de símbolos católicos na maioria das elaborações culturais observadas. Por exemplo, notamos a presença de cruzes no cemitério de Porto Velho e na Bica Canhambora e do sal (alusão ao batismo) no mito dos negros d'água. Destacamos que o episódio narrado sobre um transe coletivo em Cangume ocorreu na Festa da Santa Cruz. Assim, o catolicismo praticado na região estava enraizado em crenças centro-africanas.

As águas são importantes para a cosmologia centro-africana porque simbolizam a linha de divisão entre o mundo visível e o invisível. As águas, especialmente as do batismo, também são importantes para a cosmologia cristã. Parecem existir pontos em comum entre a travessia da kalunga e o batismo. Segundo Slenes, atravessar a kalunga significava "morrer" ou "renascer". Ou seja, era uma travessia da vida para morte ou da morte para a vida. James Henderson sublinhou que "baptizar" vem da palavra grega submergir, imergir ou afundar e que o simbolismo do batismo na água era o de morte (sepultamento na água) e ressurreição (emersão da água) ${ }^{799}$. Um terceiro rito apresenta semelhança com os dois já citados - a travessia Atlântica.

Fronteiras d'água são muito diferentes de fronteiras terrestres. Enquanto fronteiras terrestres podem ser alteradas através de avanços e recuos, fronteiras d'água dividem mundos distintos. Assim, as águas do batismo separam uma vida não cristã de uma vida cristã, a kalunga separa o mundo visível do mundo invisível e o Atlântico separa a América, a Europa e a África. Há circulação entre os diferentes mundos - os negros d'água circulam pelo mundo da terra e da água, mortos atravessam a kalunga e aparecem no mundo dos vivos, pessoas e práticas culturais (como os ritos de adivinhação e cura realizados com água) circulavam pelas diferentes partes do Império português. No entanto, as águas separam mundos diversos.

No Vale do Ribeira, a travessia do Atlântico possibilitou o encontro de três velhos mundos - representados por indígenas, africanos e europeus -, os quais formaram um novo mundo. Crenças americanas, europeias e africanas morreram e renasceram, ou seja, foram transformadas. Por exemplo, no mito do negro d'água, destacam conteúdos culturais africanos, como a crença nos espíritos das águas, os

${ }^{799}$ COUTO, Mia. O outro pé da sereia: Companhia das Letras, 2006, p. 106. 
quais foram associados à nova realidade vivida - a travessia atlântica, o catolicismo e a escravidão. O mito do "Pai Corimba" evidencia que os mitos dos seres d'água do Vale do Ribeira estavam embasados em crenças africanas. No mito do Senhor Bom Jesus, o Deus católico, predominam conteúdos europeus que também foram associados à nova realidade - a travessia atlântica e a necessidade de evangelizar os diferentes povos que compunham a sociedade colonial. Assim, tanto os negros d'água quanto o Senhor Bom Jesus de Iguape são elaborações culturais criadas a partir de conteúdos culturais preexistentes, associados a um novo contexto social.

Conforme Gruzisnki, a coexistência forçada de diferentes povos na América estimulou o aparecimento de mestiçagens, ou seja, a mistura dos seres humanos e dos imaginários ${ }^{800}$. No Vale do Ribeira e no Brasil, ocorreram mestiçagens. Assim, enquanto as águas do Atlântico marcavam a fronteira entre África, Europa e América, no Brasil, as fronteiras entre os povos originários desses continentes e seus descendentes se desvaneceram.

Talvez, o olhar estrangeiro tenha mais facilidade para perceber isso. Em 1949, acompanhado por Oswald de Andrade, Camus visitou Iguape e presenciou a Festa do Senhor Bom Jesus. Em Iguape, ele expressou sua estranheza frente à ausência de fronteiras naturais, biológicas e culturais. Ele afirmou que o Brasil era um "[...] país em que as estações se confundem umas com as outras; onde a vegetação inextricável torna-se disforme; onde os sangues misturam-se a tal ponto que a alma perdeu seus limites" 801.

\footnotetext{
${ }^{800}$ GRUZINSKI, Serge. O pensamento mestiço. Trad. de Rosa Freire d'Aguiar. São Paulo: Companhia das Letras, p. 42.

${ }^{801}$ CAMUS, Albert. Diário de Viagem. Rio de Janeiro: Record, 1997, p.107. 


\section{Fontes Documentais}

\section{Arquivos e fontes manuscritas}

\section{Casa Paroquia de Eldorado}

Livro de Tombo de Xiririca (1813-1898) - Paróquia de Eldorado (SP).

\section{Casa Paroquial de Iguape}

Livro de Tombo de Iguape (1816-1854) - Paróquia de Iguape (SP).

Livro de Tombo de Iguape (1856 - 1903) - Paróquia de Iguape (SP).

Museu Histórico e Arqueológico de Iguape.

Caixas 223, 224, 235.

Cúria Metropolitana

Pasta da Freguesia de Xiririca.

Pasta de lguape

\section{Arquivo do Estado de São Paulo}

Manuscritos - Ofícios de Recife, Xiririca, Bragança, S. Bernanrdo, P. Feliz, Montevideo, Cananéia, Paranaíba, M. Grosso, S. Carlos, Rio de Janeiro, S. Sebastião, Itapetininga - 1801-1818, Caixa 101, Ordem 351, Pasta 6

Ofícios Diversos. Xiririca - ano 1822/1843-1856. Ordem 1339, lata 544.

Ofícios Diversos de Iguape, 1818-1831, Caixa 243, ordem 1038.

Oficios Diversos, Xiririca, ano 1857 - 1891, Ordem 130, Lata 545.

Ofícios Manuscritos, Xiririca, Ordem 4823, Lata 78. 
Registro de Terras de Xiririca

Sisas 1810-1853 Iguape C08414.

Museu Paulista

(Coleção Pref. Municipal de Iguape - ano 1833 - Atas da Câmara de Iguape)

\section{Fonte Impressa}

CAVAZZI DE MONTECÚCCOLO, Padre João Antonio - Descrição histórica dos três reinos do Congo, Matamba e Angola. 2 volumes. Tradução, notas e índices pelo padre Graciano Maria de Leguzzano. Lisboa, Junta de Investigação do Ultramar, 1965. 


\section{Referências bibliográficas}

ALENCASTRO, Luiz Felipe. O Trato dos Viventes - A Formação do Brasil no Atlântico Sul. São Paulo: Companhia das Letras, 2000.

ALMEIDA, Antonio Paulino. Memória Histórica de Cananéia. São Paulo, 1963. Revista de História.

: Memória Histórica de Xiririca (El Dorado Paulista) In Boletim Volume 14, 1955, Departamento do Arquivo do Estado de São Paulo, Secretaria da Educação, São Paulo.

: Memória da Vila de Iguape. São Paulo: 1852.

Departamento de Cultura IN Separata da "Revista do Arquivo", vol. CLI.

ANDRADE, Anna Maria; TATTO, Nilto. São Paulo. Inventário Cultural de Quilombos do Vale do Ribeira. São Paulo: Instituto Sociambiental, 2013.

ANDRADE, Tânia; PEREIRA, Carlos Alberto Claro; ANDRADE, Márcia Regina de Oliveira. Negros do Ribeira: reconhecimento étnico e conquista do território. 2 ed. São Paulo: ITESP: Páginas \& Letras, 2000 (Cadernos do ITESP; 3).

BAILYN, Bernard. The idea of Atlantic History In: Internacional Seminar on the History of the Atlantic World, 1500-1800. Working Paper $\mathrm{n}^{\circ}$ 96-01, Harvard University, 1996.

BARLOW, Maude. Pacto Azul. Mbooks Editora, 2009.

BETHENCOURT, Francisco. O imaginário da magia: feiticeiras, saludadores e nigromantes no Século XVI. Lisboa: Centro de Estudos de História e Cultura Portuguesa, 1987.

CALAINHO, Daniela, Buono. Metrópole das Mandingas: religiosidade negra e inquisição portuguesa no Antigo Regime: Garamond, 2008

CAMINHA, Pero Vaz. A Carta de Pero Vaz de Caminha. Rio de Janeiro: Livraria Agir Editora, 1965.

CANDIDO, Antonio. Os parceiros do Rio Bonito: estudo sobre o caipira paulista e as transformações dos seus meios de vida. 3 ed. São Paulo: Duas Cidades, 1964,

CARNEIRO, Edison. Religiões Negras: notas de etnografia religiosa. Rio de Janeiro: Civilização Brasileira, 1936. 
CARRIL, Lourdes de Fátima Bezerra. Terra de Negros no Vale do Ribeira: territorialidade e resistência. Dissertação (Mestrado), 1995, Universidade de São Paulo. Faculdade de Filosofia, Letras e Ciências Humanas. Departamento de História.

CARVALHO, Maria Celina. Negros do Ribeira: Feitiçaria, curandores e catolicismo popular. $3^{a}$ Prêmio Territórios Quilombolas. Ministério do Desenvolvimento Agrário, Brasília, 2011.

CASCUDO, Luís da Câmara. Dicionário do Folclore Brasileiro. Ediouro Publicações Ltda. 10 edição, Rio de Janeiro, 1998, p. 209.

, Geografia dos Mitos Brasileiros. São Paulo: Global,

2002.

Brasileira S.A, 1965.

Made in África. Rio de Janeiro: Editora Civilização

Centro de Apoio Operacional das Promotorias de Direitos Constitucionais. Implantação da Usina Hidrelétrica de Tijuco Alto Disponível em $<\underline{\text { http://www.direito.caop.mp.pr.gov.br/modules/noticias/article.php?storyid=247 }}$

CHATELAIN, Henri. Contos Populares de Angola. Cinquenta contos em quimbundo. Lisboa: Agência Geral do Ultramar, 1964.

CHILDS, Gladwyn Murray. The People of Angola in the Seventeenth Century according to Cadornega, em The Journal of African History; vol. 1, n.2 (1960).

DOULA, Sheila Maria. Piratas: discursos e silêncios. Piratas: discursos e silêncios. Tese (Doutorado), 1997, Universidade de São Paulo. Faculdade de Filosofia, Letras e Ciências Humanas. Departamento de Antropologia.

FERREIRA, Lúcia de Fátima Guerra. Igreja e Romanização: a implantação da diocese da Paraíba. São Paulo, 1994. Tese (Doutorado). FFLCH-USP.

FORTES, Roberto. Major Young, Um inglês que fez Iguape. Disponível em: $<$ http://robertofortes.fotoblog.uol.com.br/photo20050202194012.html

FIGUEIREDO, Luiz Afonso Vaz. O meio ambiente prejudicou a gente. Campinas, 2000, 1994. Tese (Doutorado). FFLCH - USP

FRANÇA, Maria Cecília. Pequenos Centros Paulistas de Função Religiosa. São Paulo: FFLCH/USP, 1975. Volumes 1 e 2.

GALVÃO, Eduardo. Santos e visagens: um estudo da vida religiosa de Itá, Baixo Amazonas. $2^{a}$ ed . São Paulo : Companhia Editora Nacional, 1976.

GOMES, F. S. Quilombos do Rio de Janeiro no século XIX In REIS, J. R. e GOMES, F. S. (orgs). Liberdade por um fio: História dos Quilombos no Brasil. São Paulo: Cia. das Letras, 1996 
GONÇALVES, Rosana Andre. Africa Indômita: missionários capuchinhos no reino do Congo (séc. XVII), São Paulo, 2008. Dissertação (Mestrado). FFLCH - USP.

GRUZINSKI, Serge. O pensamento mestiço. Tradução Rosa Freire d'Aguiar. São Paulo: Companhia das Letras

HEINTZ, Beatrix. Angola nos séculos XVI e XVII. Estudo sobre fontes, métodos e história. Tradução de Marina Santos. Luanda, Kilombelombe, 2007.

HOLANDA, Sérgio Buarque. Caminhos e fronteiras. Rio de Janeiro: J. Olympio: Prolivro, 1975.

Econômico. Ano III, $\mathrm{n}^{\circ}$ 31, p. 56-58, jan. 1947.

O arroz em São Paulo na era colonial. Digesto

INSTITUTO DE TERRAS DO ESTADO DE SÃO PAULO, Relatório técnico-científico da Comunidade Remanescente de Quilombo de Cangume. São Paulo: Itesp, 2003.

INSTITUTO DE TERRAS DO ESTADO DE SÃO PAULO. Relatório técnico-científico da Comunidade Remanescente de Quilombo de Porto Velho.

INSTITUTO DE TERRAS DO ESTADO DE SÃO PAULO. Relatório técnico-científico da Comunidade Remanescente de Quilombo de Praia Grande. São Paulo: Itesp, 2003.

INSTITUTO SOCIOAMBIENTA. O Projeto Tijuco Alto e seu histórico. Disponível em $<$ http://www.socioambiental.org/inst/camp/Ribeira/tijuco

JORGE, Janes. O rio que a cidade perdeu: São Paulo, 1890-1940. São Paulo. Editora Alameda. 2006

KRUG Edmundo. A superstição paulistana IN Revista do Instituto Histórico e Geográfico do Estado de São Paulo, 1910

. Xiririca, Ivaporundiba e Iporanga. IN Revista do Instituto Histórico

e Geográfico de São Paulo, volume XVIII, 1912, 2 ed., São Paulo, 1942.

KRUG : A Ribeira de Iguape. IN Separata do Boletim de Agricultura, Série 39, 1938. Secretaria de Agricultura, Indústria e Comércio do Estado de São Paulo, 1939.

LEITE, Serafim. Cartas dos Primeiros Jesuítas do Brasil. Coimbra: Atlântida, 1956. Edição para a Comissão do IV Centenário da Cidade de São Paulo.

Portugalia 1938.

História da Companhia de Jesus no Brasil. Vol. 6. Lisboa: Livraria

LIENHARD. Martin. O Mar e o Mato. Histórias da Escravidão (Congo-Angola, Brasil, Caribe). Salvador : EDUFBA/CEAO, 1998

LUZ, Rubens Calazans. Santo Antonio das Minas de Apiahy. São Paulo: Gráfica Regional, 1996. 
MACGAFFEY, Wyatt. Dialogues of the Deafs: Europens on the Atlantic Coast of Africa. In: SCHWARTZ, Stuart. Implicits Understanding - Observing, Reporting and Reflecting on the Encounters Between Europeans and Other People in the Early Modern Era. Cambridge: The Cambridge University Press, 1994.

Twins, Simbi Spirits, and Lwas in Kongo and Haiti.n Heywood, Linda M. (Ed). Central Africans and Cultural Transformations in the American Diaspora. Cambridge: Cambridge University Press, 2002.

Relion and society in Central Africa. The Bakongo of Lower Zaire. Chicago: The University of Chicago Press, 1986.

MACHADO, Maria Helena Pereira Toledo. Vivendo na mais perfeita desordem: os libertos e o modo de vida camponês na província de São Paulo no século XIX. Estudos Afro-Asiáticos, (25): 25-42, dezembro de 1993.

O Plano e o Pânico. Os Movimentos Sociais na Década da Abolição.. 2o.. ed. São Paulo: EDUSP, 2010.

MADRE de DEUS, Frei Gaspar da. Memória para a História da Capitania de São Vicente. Belo Horizonte: Itatiaia/ Edusp, 1975.

MAFFEY, Lucy de Abreu; NOGUEIRA, Arlinda Rocha. O ouro na Capitania de São Vicente nos Séculos XVI e XVII. In Anais do Museu Paulista, V. 20, p. 8-35, 1966.

MAGNOLI, Demétrio. O corpo da pátria. Imaginação Geográfica e Política Externa no Brasil (1808-1912). Editora Moderna. 1997.

MANCEBO, Oswald. Apiaí: do sertão à civilização. São Paulo: Ômega, 2001.

MARCÍLIO, Maria Luiza. Crescimento Demográfico e Evolução Agrária Paulista, 1700-1836. São Paulo: Edusp/ Hucitec, 2000.

MARQUES, João Francisco. Metáforas do sal na oratória sacra do seiscentismo português. I Seminário Internacional sobre o sal português. Instituto de História Moderna da Universidade do Porto, 2005.

MARTINEZ, Maria Cecília. Ação governamental e resistência camponesa no Vale do Ribeira. São Paulo 1995. Dissertação (Mestrado). FFLCH-USP.

MATTOS, Regiane Augusto de. De Cassange, mina, benguela a Gentio da Guiné. Grupos Étnicos e formação de identidades africanas na cidade de São Paulo (18001850), Dissertação de Mestrado, 2006, Universidade de São Paulo. Faculdade de Filosofia, Letras e Ciências Humanas. Departamento de História.

MENDES, Francisco Alexandre Ferreira. Folclore Mato-grossense. Edição da Fundação Cultural do Mato Grosso, 1977.

MILLER, Joseph C. Poder político e parentesco. Os antigos estados mbundu em Angola. Tradução Maria da Conceição Neto. Luanda, Arquivo Nacional/ Ministério da Cultura, 1995. 
MINTZ, Sidney; PRICE, Richard. O nascimento da cultura afro-americana. Uma perspectiva antropológica. Trad: Vera Ribeiro. Rio de Janeiro: Pallas; UCAM, 2003.

MIRALES, Rosana. A identidade quilombola das comunidades Pedro Cubas e Ivaporunduva. Mestrado - Programa de Ciências Socias. PUC - São Paulo. 1998.

MUNANGA, Kabengele. Negritudes: usos e sentidos. Belo Horizonte: Autêntica, 2009.

1995/96, p. 56-63.

Origem e histórico do quilombo na África. São Paulo,

OBI, T. J. Desch, Combat and the Crossing of the Kalunga. In: HEYWOOD, Linda M. (Ed.). Central Africans and Cultural Transformations in the American Diaspora. Cambridge: Cambridge University Press, 2002.

PAES, Gabriela Segarra Martins. A Recomendação das Almas na Comunidade Remanescente de Quilombo de Pedro Cubas. São Paulo, 2007. Dissertação (Mestrado). FFLCH-USP.

PARDAL, Paulo. Carrancas do São Francisco. Serviço de Documentação da Marinha. Rio de Janeiro, 1974.

PARREIRA, Adriano. Economia e Sociedade em Angola na Época da Rainha Jinga, Século XVII. Lisboa: Editorial Estampa, 1997.

PEREIRA QUEIROZ, Maria Isaura. Vale do Ribeira: pesquisas sociológicas. São Paulo, Faculdade de Filosofia, Letras e Ciências Humanas/ USP. 1967,

Cidades, 1973. , Maria Isaura. Bairros Rurais Paulistas. São Paulo: Duas

PEREIRA, Nunos Marques. Compêndio narrativo do Peregrino da América. 6 ed. Rio de Janeiro: Publicação da Academia Brasileira, 1939, v.l,

PESSOA, Fernando. Mensagem. Mar Português. Edições Ática: Lisboa. 1959.

PETRONE, Pasquale. A Baixada do Ribeira: estudo de geografia humana. 1960. Tese (Doutorado em Geografia) - Universidade de São Paulo,

A Baixada do Ribeira: estudo de geografa humana. São Paulo: FFLCH - USP. Boletim n 283 (Cadeira de Geografia ${ }^{\circ}$ 14), 1966.

QUEIROZ, Renato da Silva. Negros do Vale do Ribeira. Um estudo de antropologia econômica. São Paulo: Edusp, 2006

Caminhos que andam: os rios e a cultura brasileira IN

Águas Doces no Brasil: Capital Ecológico, Uso e Conservação. Organizadores: Rebouças, Aldo da Cunha; BRAGA, Benedito; TUNDISI, José Galizia. 3 ed. São Paulo: Escrituras Editora, 2006.

RAMOS, Arthur. O folclore negro do Brasil: Demopsicologia e psicanálise; Arthur 
Ramos - 3. ed. - São Paulo: WMF Martins Fontes, 2007.

Fragmentos Geológicos e Geográficos para a parte Physica da Estatística das Províncias de S. Paulo e Paraná. São Paulo: Imparcial, 1856.

REGINALDO, L. . Irmandades e devoções de africanos e crioulos na Bahia setecentista: histórias e experiências atlânticas. Stockholm Review of Latin American Studies, v. 1, p. 24-34, 2009.

Senhora do Rosário dos Pretos, São Benedito de Quissama: irmandades e devoções atlânticas no Bispado de Angola, século XVIII. In: PAIVA, Eduardo França; SANTOS, Vanicléia Silva.. (Org.). África e Brasil no Mundo Moderno. 1ed.São Paulo: Anablume, 2012, v. 1, p. 117-133.

REIS, João José. A morte é uma festa: ritos fúnebres e revolta popular no Brasil do século XIX. São Paulo: Cia. Das Letras, 1991.

RODRIGUES, Jaime. De costa a costa. Escravos, marinhos e intermediários do tráfico negreiro de Angola ao Rio de Janeiro (1780 - 1860). São Paulo: Companhia das Letras, 2005.

RODRIGUES, Nina. Os africanos no Brasil. Brasília: Editora da Universidade de Brasília, 2004.

SAINT HILAIRE, Augusto de. Viagem a Província de São Paulo. Trad. Rubens Borba de Moraes. São Paulo: Martins, 1945.

SANCHEZ, Fábio Jose Bechara. Identidade e conflito: a construção política dos "remanescentes de quilombo" do Vale do Ribeira. São Paulo, 2004. Dissertação (Mestrado). FFLCH - USP,

SANTOS, Georgina Silva dos, Devoções Atlânticas: A construção da identidade social e religiosa de cativos e libertos na Bahia Colonial. Afro-Asia, 46 (2012).

SCHLEUMER, Fabiana. Bexigas, Curas e Calundus: caminhos da morte entre escravos em São Paulo e seus arredores (Século XVIIII). Tese (Doutorado). Universidade de São Paulo. 2005

SCHULER. Monica. Liberated Central Africans in Nineteenth-Century Guyana. In: HEYWOOD, Linda M. (Ed.). Central Africans and Cultural Transformations in the American Diaspora. Cambridge: Cambridge University Press, 2002.

SILVA, Juliana Ribeiro da. Homens de ferro: os ferreiros na África Central no século XIX. Dissertação (Mestrado). FFLCH-USP.

SLENES, Robert W., 'Malungo, Ngoma vem': África coberta e descoberta no Brasil. Revista USP, 12, 1991/92.

. "The Great Porpoise-Skull", In Heywood, Linda M. (Ed). Central Africans and Cultural Transformations in the American Diaspora. Cambridge: Cambridge University Press, 2002.

A Grande Greve do Crânio do Tucuxi: Espíritos das Águas 
Centro-Africanas e Identidade Escrava no Início do Século XIX no Rio de Janeiro In HEYWOOD, Linda (org). Diáspora negra no Brasil. Tradução; Ingrid de Castro Vompean Fregonez, Thaís Cristina Casson, Vera Lúcia Benedito. 1 ed. São Paulo: Contexto, 2009.

SOUZA, Juliana Beatriz Almeida. Virgem Mestiça: devoção à Nossa Senhora na colonização do Novo Mundo. Tempo, Niterói, v. 6, n. 11, 2001, p. 88-90.

Souza, Laura de Mello. Inferno Atlântico: demonologia e colonização século XVIXVIII. São Paulo: Companhia das Letras, 2001

Revisitando o calundu. Gorenstein, Lina; Maria Luiza Tucci, orgs. Ensaios sobre a intolerância: inquisição, marranismo e anti-semitismo, São Paulo: Humanitas, 2005.

O diabo e a terra de Santa Cruz: feitiçaria e religiosidade popular no Brasil colonial. São Paulo: Companhia das Letras, 2009.

SOUZA, Marina de Mello e Souza. Santo Antonio de nó-de-pinho e o catolicismo afro-brasileiro. Tempo, Niterói, v. 6, n. 11, 2001.

Reis Negros no Brasil escravista: História da Festa da Coroação de Rei Congo. Belo Horizonte: Ed. UFMG, 2002.

Catolicismo Negro no Brasil Afro-Asia, Salvador, $n^{\circ} 28,2002$,

p $125-146$.

: A rainha jinga de Matamba e o catolicismo - África Central, século XVII, em Las relaciones discretas entre las Monarquias Hispana y Portuguesa: Las Casas de Las Reina (siglos XV-XIX). Madri, Polifemo, 2009.

, Crucifixos centro-africanos: um estudo sobre traduções simbólicas. In: ALGRANTI, L. M. e MEGIANI, A. P. (Orgs.). Império por escrito: formas de transmissão da cultura letrada no mundo ibérico (XVI-XIX). São Paulo: Alameda, 2009.

STUCCHI, Débora; OLIVEIRA JUNIOR, Adolfo N.; CHAGAS, Miriam; BRASILEIRO, Sheila dos S. 2000. Laudo antropológico das comunidades negras de Ivaporunduva, São Pedro, Pedro Cubas, Sapatu, Nhunguara, André Lopes, Maria Rosa e Pilões In ANDRADE, Tânia (ed.). Negros do Ribeira: reconhecimento étnico e conquista do território. São Paulo, ITESP.

SWEET, James. Recreating Africa. Culture, Kinship, and Religion in the AfricanPortuguese World, 1441-1770. The University of North Carolina Press, 2003.

SWEET, James H. Recriar África: cultura, parentesco e religião no mundo afroportuguês (1441-1770). Tradução João Reis Nunes. Lisboa: Edições 70, 2007.

TAQUES, Pedro. Notícias das Minas de S. Paulo e dos sertões da mesma Capitania. S. Paulo: Martins, 1954. 
THOMPSON, Robert Farris. Flash of the Spirit. African and afro-american art and philosophy. New York: Vintage Books, 1984.

THORNTON, John K. and HEYWOOD, Linda M., Central Africans, Atlantic Creoles and the Foundation of the Americas, 1585-1660. Cambrigde University Press, 2002.

A África e os africanos na formação do mundo atlântico, 1400-1800. Trad. Marisa Rocha Motta. Rio de Janeiro: Ed. Campus; Elsevier, 2000. Religião e Vida cerimonial no Congo e Áreas Umbundo, de 1500 a 1700. In HEYWOOD, Linda (org). Diáspora negra no Brasil. Tradução; Ingrid de Castro Vompean Fregonez, Thaís Cristina Casson, Vera Lúcia Benedito. 1 ed. São Paulo: Contexto, 2009.

VAINFAS, Ronaldo (org). Dicionário do Brasil Colonial (1500-1808). Rio de Janeiro: Editora Objetiva, 2000

VALENTIN, Agnaldo. Nem Minas, Nem São Paulo: economia e demografia na localidade paulista de Apiaí (1732-1835). 2001. Dissertação (Mestrado).

. Uma civilização do arroz: agricultura, comércio e subsistência no Vale do Ribeira (1800-1880). 2006. Tese (Doutorado em História Econômica) Faculdade de Filosofia, Letras e Ciências Humanas da Universidade de São Paulo FFLCH-USP.

VIEIRA, Antônio. Sermões. São Paulo: Hedra, 2001. Sermões escolhidos. São Paulo: Editora Martin Claret, 2004.

WISSENBACH, Maria Cristina Cortez. Sonhos africanos, vivência ladinas. Escravos e forros em São Paulo (1850-1880). São Paulo: Hucitec, 1998.

Ritos de magia e sobrevivência : sociabilidades e práticas mágico-religiosas no Brasil (1890/1940). Tese (Doutorado), FFLCH-USP, 1997.

YOUNG, Ernesto Guilherme. História de Iguape in "Revista do Instituto Histórico e Geográfico de São Paulo”, Vol. VIII, São Paulo, 1904.

Subsídios para a história de Iguape. In "Revista do Instituto Histórico e Geográfico de São Paulo, 1901. 
SITUAÇÃO DAS COMUNIDADES DE QUILOMBO NO ESTADO DE SÃO PAULO $\mathrm{abri1} / 2014$

Comunidades Reconhecidas (28); Tituladas (6*)

\begin{tabular}{|c|c|c|c|c|}
\hline Comunidade & Município & $\begin{array}{c}\text { Área } \\
\text { particular } \\
\text { (ha ) }\end{array}$ & $\begin{array}{r}\text { Famílias } \\
\left(\mathrm{N}^{\circ}\right)\end{array}$ & $\begin{array}{c}\text { Ano do } \\
\text { reconhecimento }\end{array}$ \\
\hline 1.Ivaporunduva & Eldorado & $2.082,07$ & 98 & 1998 * \\
\hline 2.Maria Rosa & Iporanga & 0,00 & 25 & 1998 * \\
\hline 3.Pedro Cubas & Eldorado & $1.356,84$ & 40 & 1998 * \\
\hline 4.Pilões & Iporanga & 296,31 & 63 & 1998 * \\
\hline 5.São Pedro & Eldorado/Iporanga & 130,07 & 39 & 1998 * \\
\hline 6.Cafundó & Salto de Pirapora & 209,64 & 24 & 1999 \\
\hline 7.Caçandoca & Ubatuba & discriminatória & 50 & 2000 \\
\hline 8.Jaó & Itapeva & 165,77 & 53 & 2000 \\
\hline 9.André Lopes & Eldorado & 76,14 & 76 & 2001 \\
\hline 10.Nhunguara & Eldorado/Iporanga & 0,00 & 91 & 2001 \\
\hline 11.Sapatu & Eldorado & $2.127,56$ & 82 & 2001 \\
\hline 12.Galvão & Eldorado/Iporanga & 291,50 & 34 & $2001^{*}$ \\
\hline 13.Mandira & Cananéia & $\begin{array}{r}\text { área não } \\
\text { discriminada }\end{array}$ & 16 & 2002 \\
\hline 14.Praia Grande & Iporanga & $1.104,26$ & 34 & 2002 \\
\hline 15.Porto Velho & Iporanga & 941,00 & 19 & 2003 \\
\hline 16.Pedro Cubas de Cima & Eldorado & $3.800,24$ & 22 & 2003 \\
\hline 17.Capivari & Capivari & 6,93 & 17 & 2004 \\
\hline 18.Brotas & Itatiba & 12,48 & 32 & 2004 \\
\hline 19.Cangume & Itaóca & 724,60 & 37 & 2004 \\
\hline 20.Camburi & Ubatuba & discriminatória & 39 & 2005 \\
\hline 21. Morro Seco & Iguape & 164,69 & 47 & 2006 \\
\hline 22. Poça & Eldorado/Jacupiranga & $1.126,14$ & 41 & 2008 \\
\hline $\begin{array}{l}\text { 23. Ribeirão } \\
\text { Grande/Terra Seca }\end{array}$ & Barra do Turvo & $2.522,17$ & 77 & 2008 \\
\hline 24. Cedro & Barra do Turvo & $1.066,11$ & 23 & 2009 \\
\hline 25. Reginaldo & Barra do Turvo & 1. 071,45 & 94 & 2009 \\
\hline 26. Pedra Preta/Paraiso & Barra do Turvo & $3.280,26$ & 80 & 2009 \\
\hline $\begin{array}{l}\text { 27. Sertão de } \\
\text { Itamambuca }\end{array}$ & Ubatuba & discriminatória & 31 & 2010 \\
\hline 28. Peropava & Registro & 395,98 & 25 & 2011 \\
\hline
\end{tabular}

Comunidades em fase de reconhecimento cujos estudos estão finalizados, aguardando definição de área (4)

\begin{tabular}{|l|r|r|r|}
\hline \multicolumn{1}{|c|}{ Comunidade } & Município & \multicolumn{1}{c|}{ Área total ha } & Famílias \\
\hline 1. Bombas & Iporanga & $3.200,00$ & 16 \\
\hline 2. Fazenda Picinguaba & Ubatuba & 795,23 & 40 \\
\hline 3. Piririca & Iporanga & $1.441,64$ & 14 \\
\hline 4. Biguazinho & Miracatu & 790,00 & 09 \\
\hline
\end{tabular}

Comunidades cujos trabalhos estão em andamento(4)

\begin{tabular}{|l|c|c|c|}
\hline \multicolumn{1}{|c|}{ Comunidade } & Município & Área total ha & Famílias \\
\hline 1. Retiro da Ex Colônia Velha & Cananéia & & \\
\hline 2. Abobral Margem Esquerda & Eldorado & & \\
\hline 3. Bairro do Engenho & Eldorado & & \\
\hline 4. Bairro da Aldeia & Iguape & & \\
\hline
\end{tabular}

Comunidades apontadas para o Reconhecimento (14).

\begin{tabular}{|l|l|l|l|}
\hline \multicolumn{1}{|c|}{ Comunidade } & \multicolumn{1}{|c|}{ Município } & Área total & Familias \\
\hline 1. Castelhanos & Iporanga & & \\
\hline 2. Bananal Pequeno & Eldorado & & \\
\hline 3. Chácara dos Pretos & Rio claro & & \\
\hline 4. Tamandaré & Guaratinguetá & & \\
\hline 5. Poço Grande & Iporanga & & \\
\hline
\end{tabular}




\begin{tabular}{|l|l|l|l|}
\hline 6. Anta Magra & Barra do Chapéu & & \\
\hline 7. Tocos & Barra do Chapéu & & \\
\hline 8. Piraporinha,Jucurupava e Itinga & Salto de Pirapora & & \\
\hline 9. Cachambu & Sarapui & & \\
\hline 10. Bairro do Quilombo & São Bento do Sapucaí & & \\
\hline 11. Fazendinha Pilar & Pilar do Sul & & \\
\hline 12. Os Camargos & Votorantim/Salto de pirapora & & \\
\hline 13.Carmo & São Roque & & \\
\hline 14. Fazendinha dos Pretos & Salto de Pirapora & & \\
\hline
\end{tabular}

Fonte: Fundação ITESP 


\section{Fotos}

- Descendo o Rio Ribeira de Iguape (Fotos contidas no Cadastro de Terra e Regularização Fundiária - Créditos: Gerard e Magi Moss).

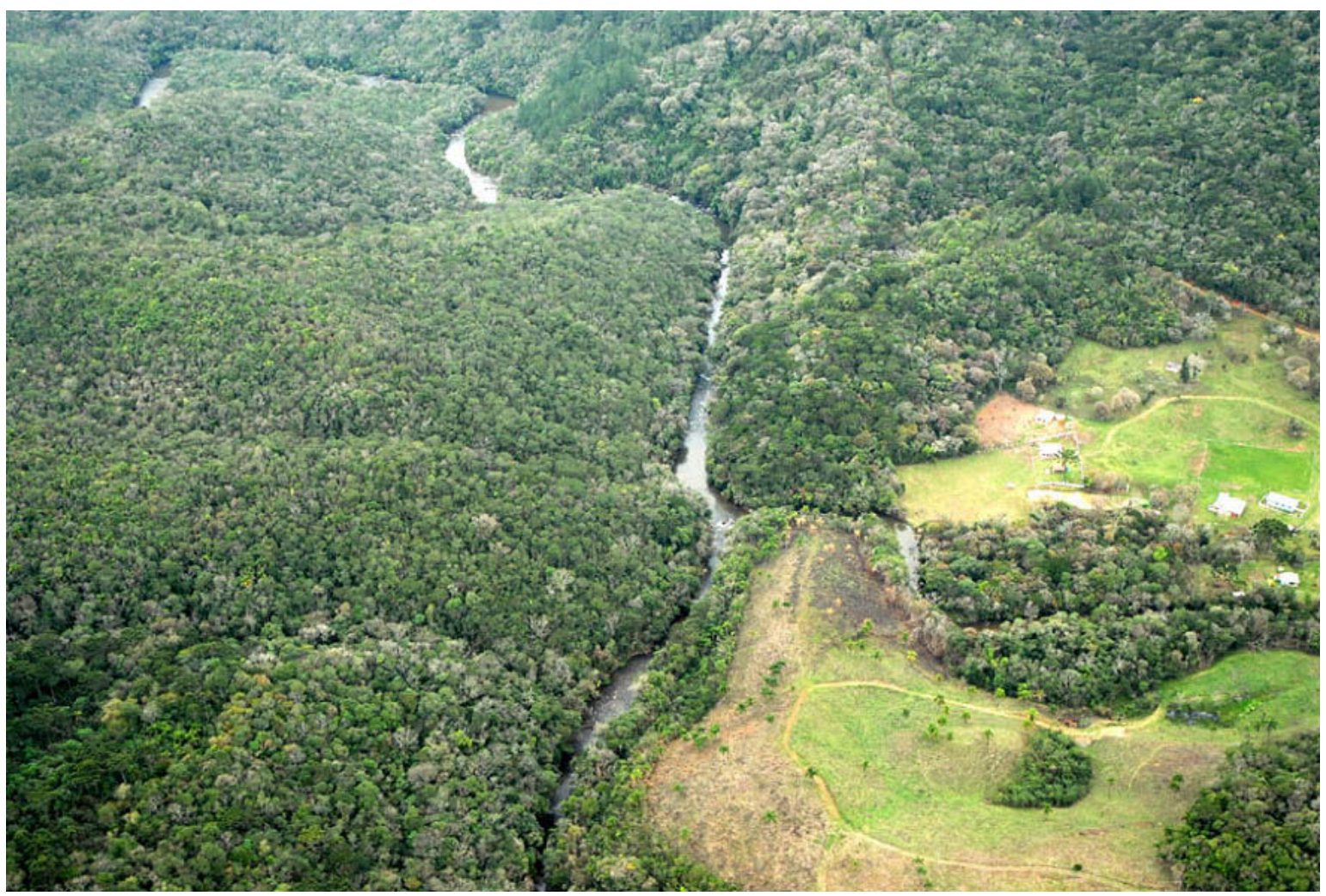




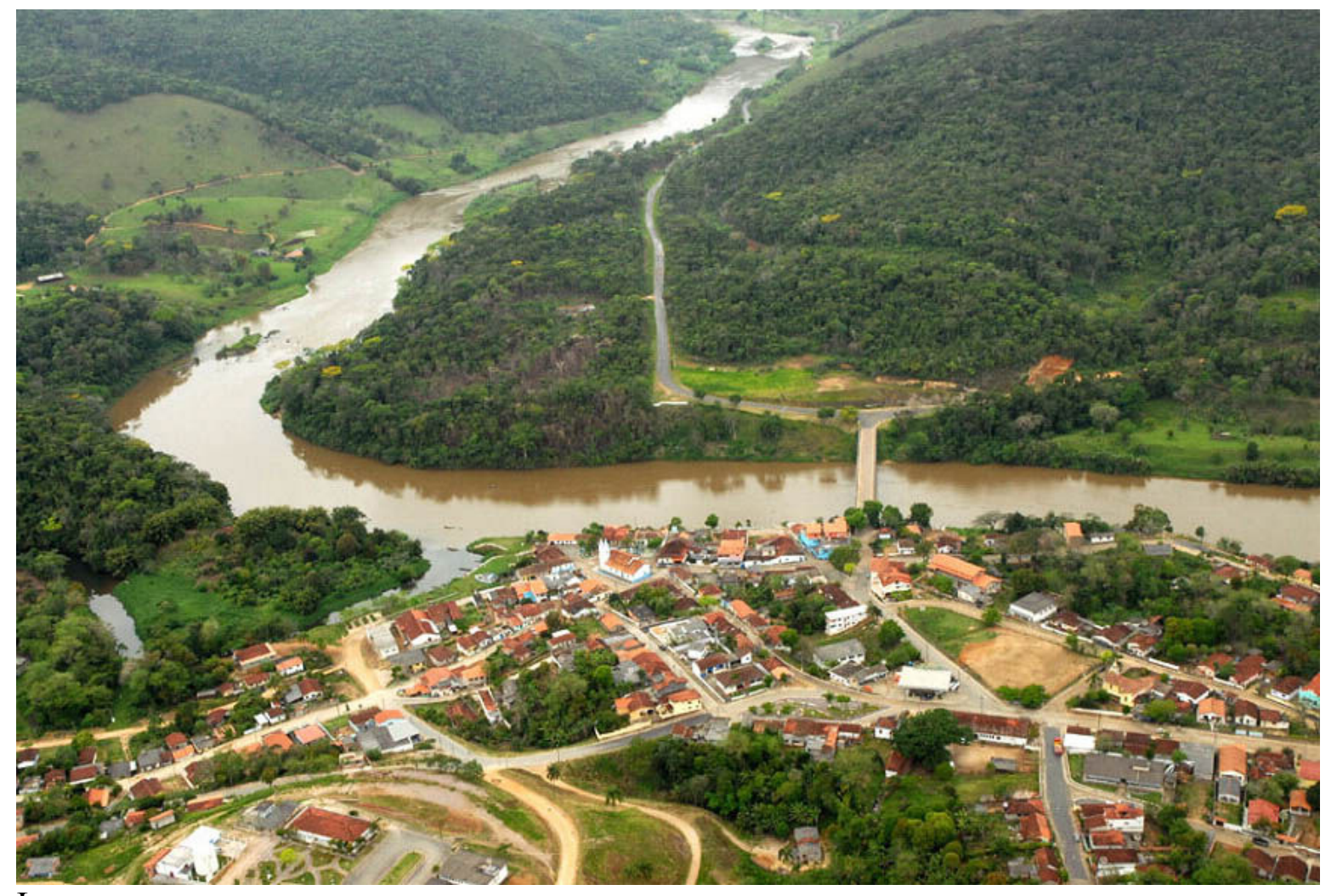

Iporanga

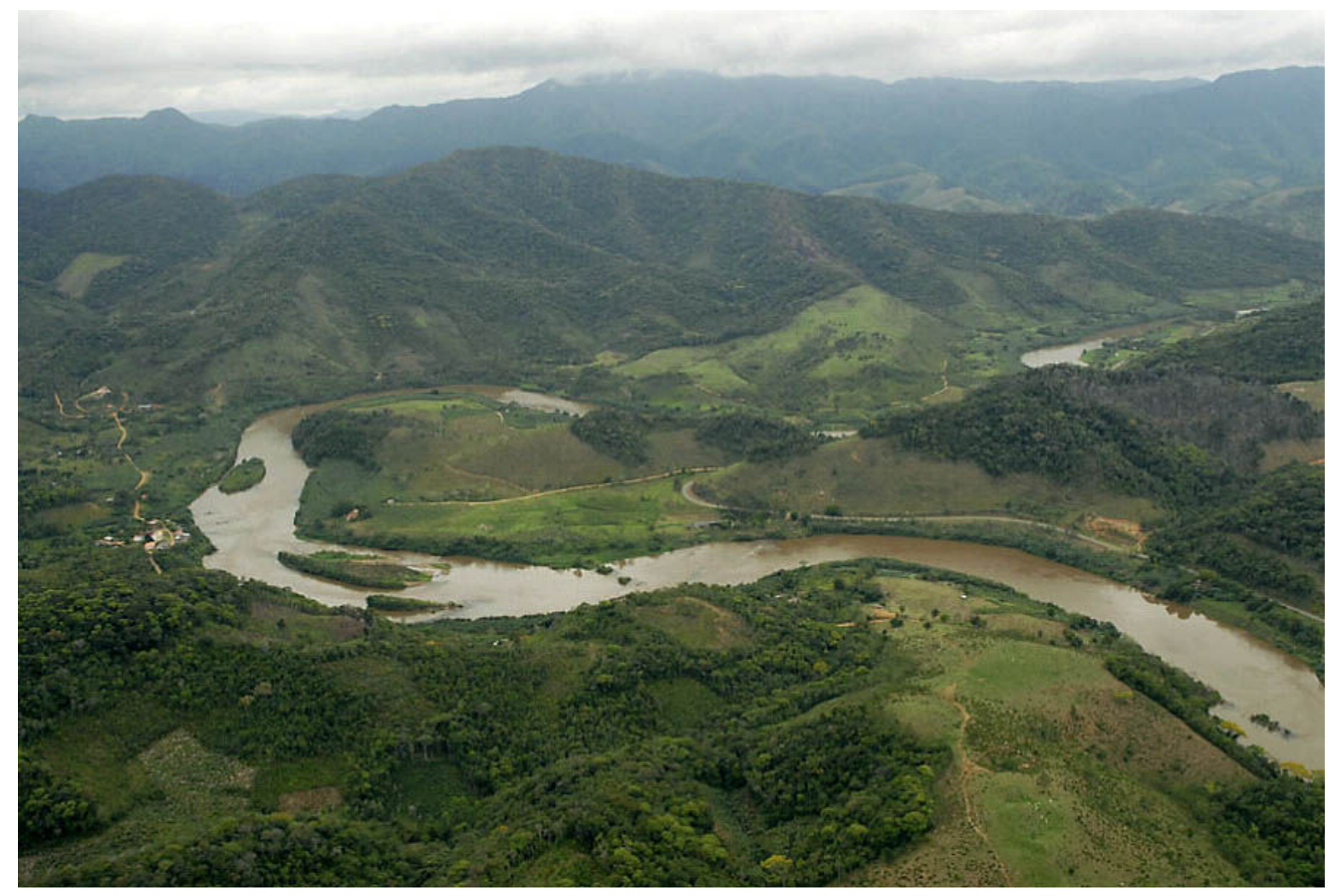



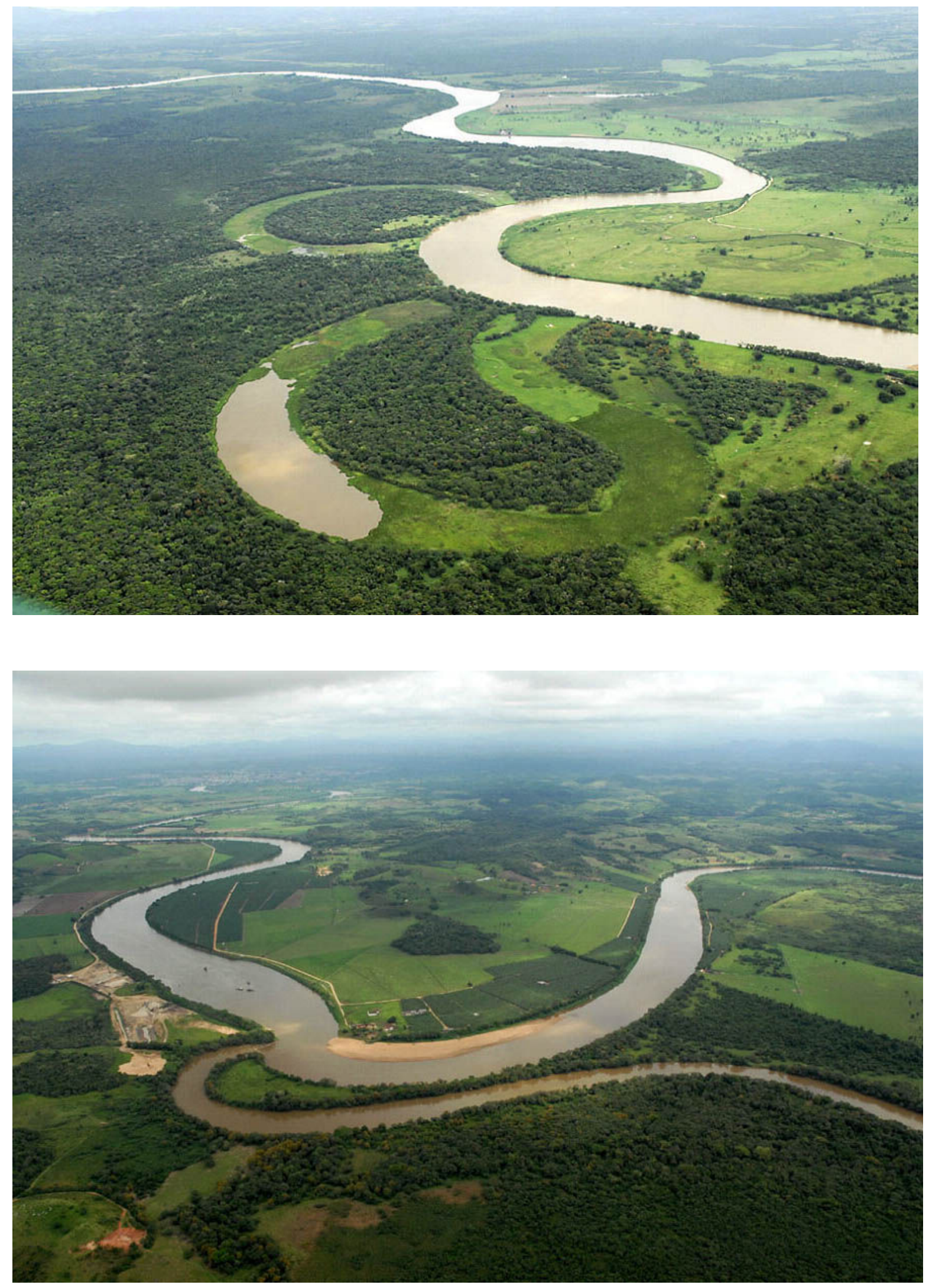

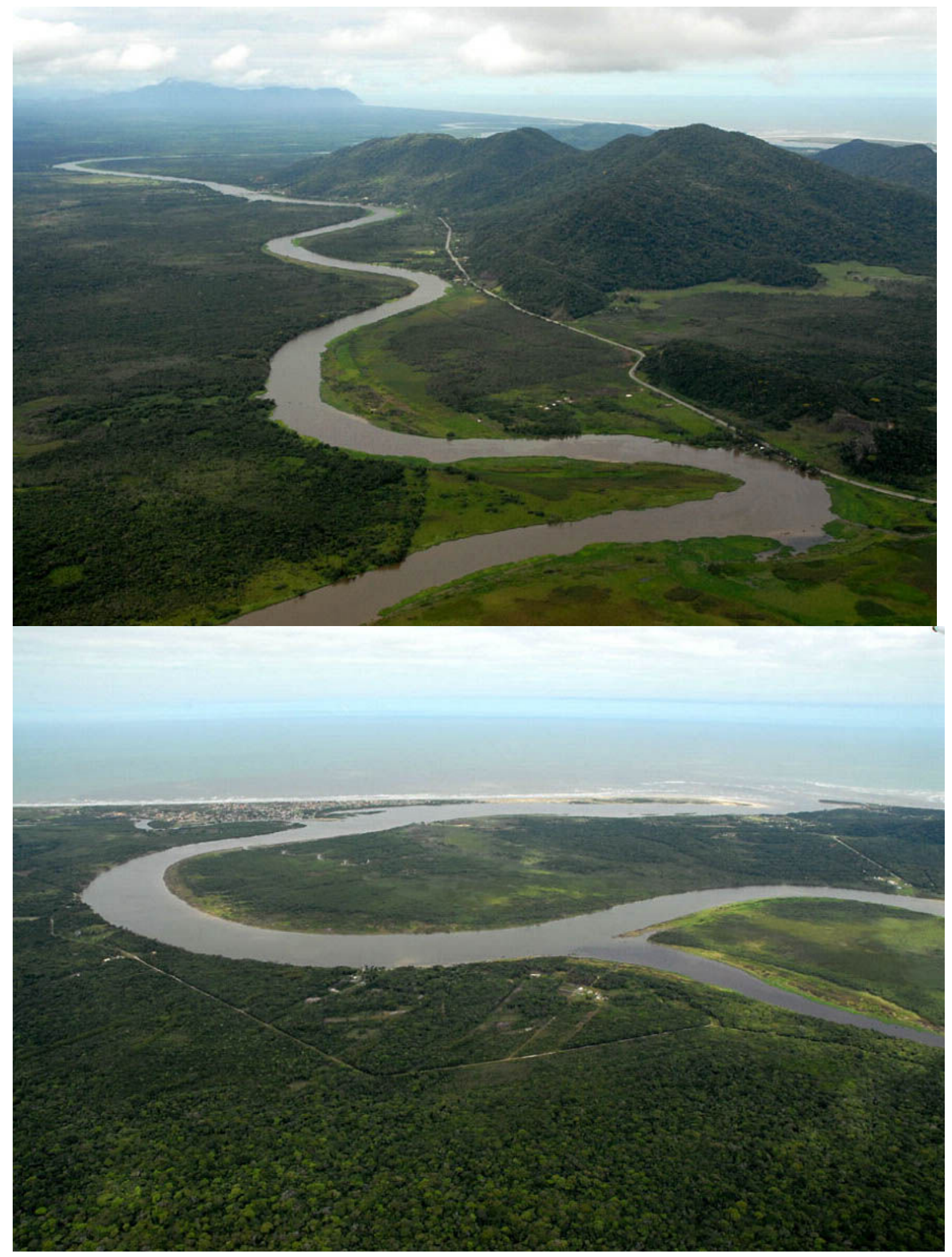


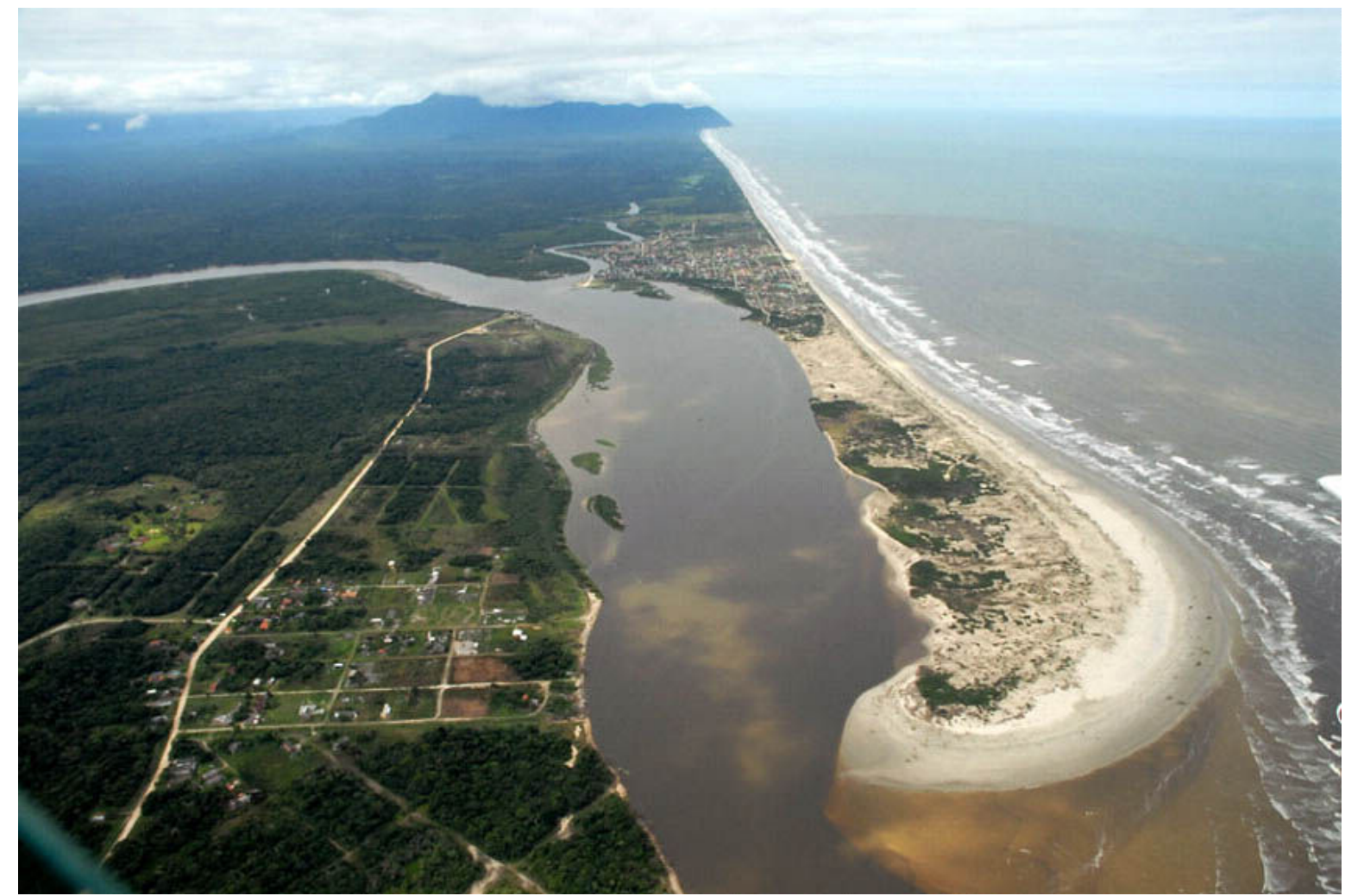

Chegada do Rio Ribeira de Iguape ao mar. 


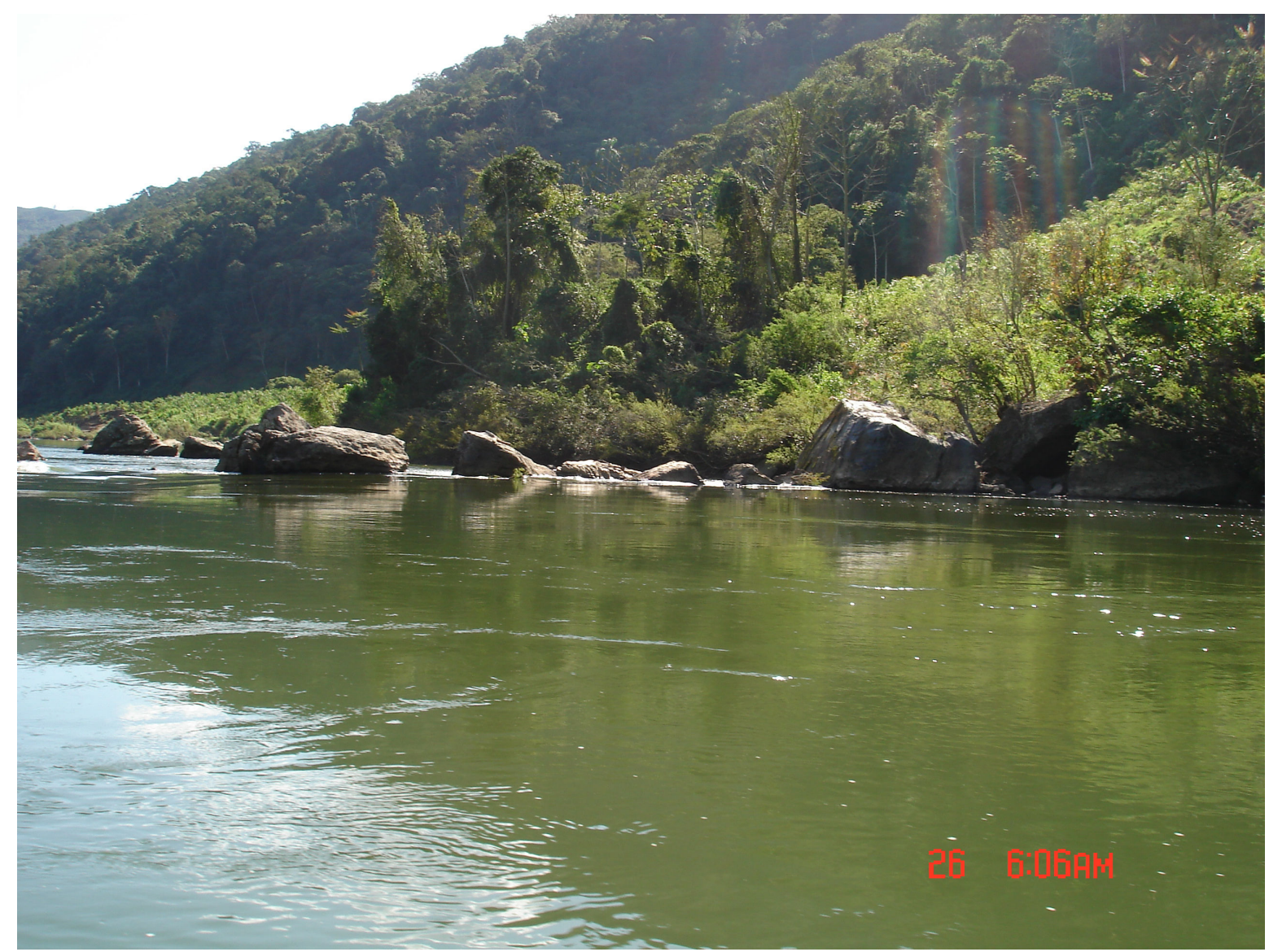

Rio Ribeira de Iguape, 2012. Foto: Gabriela Segarra Martins Paes. 


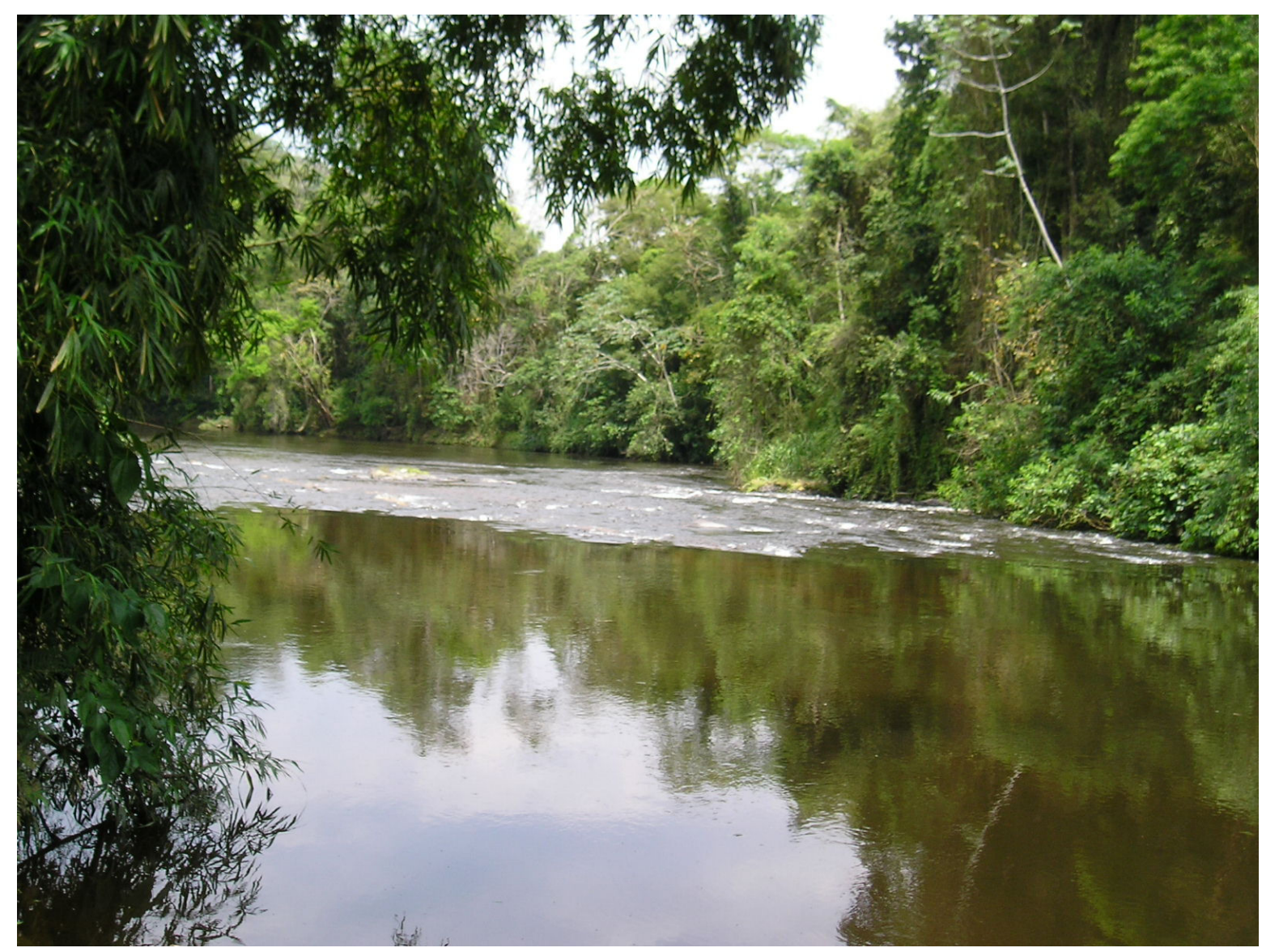

Afluente do Rio Ribeira, 2007. Arquivo da Fundação ITESP

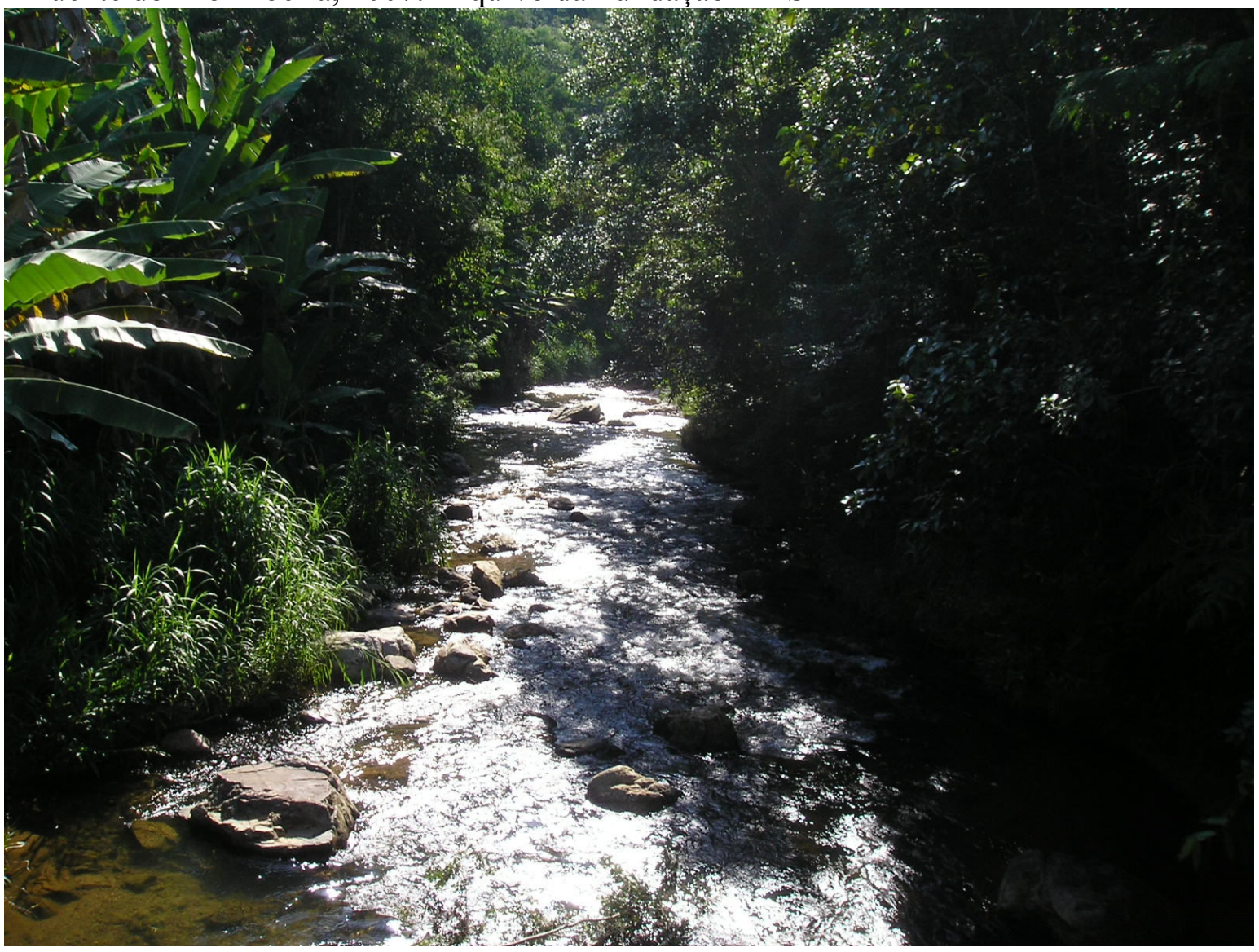

Rio Nhunguara, Arquivo da Fundação ITESP. 


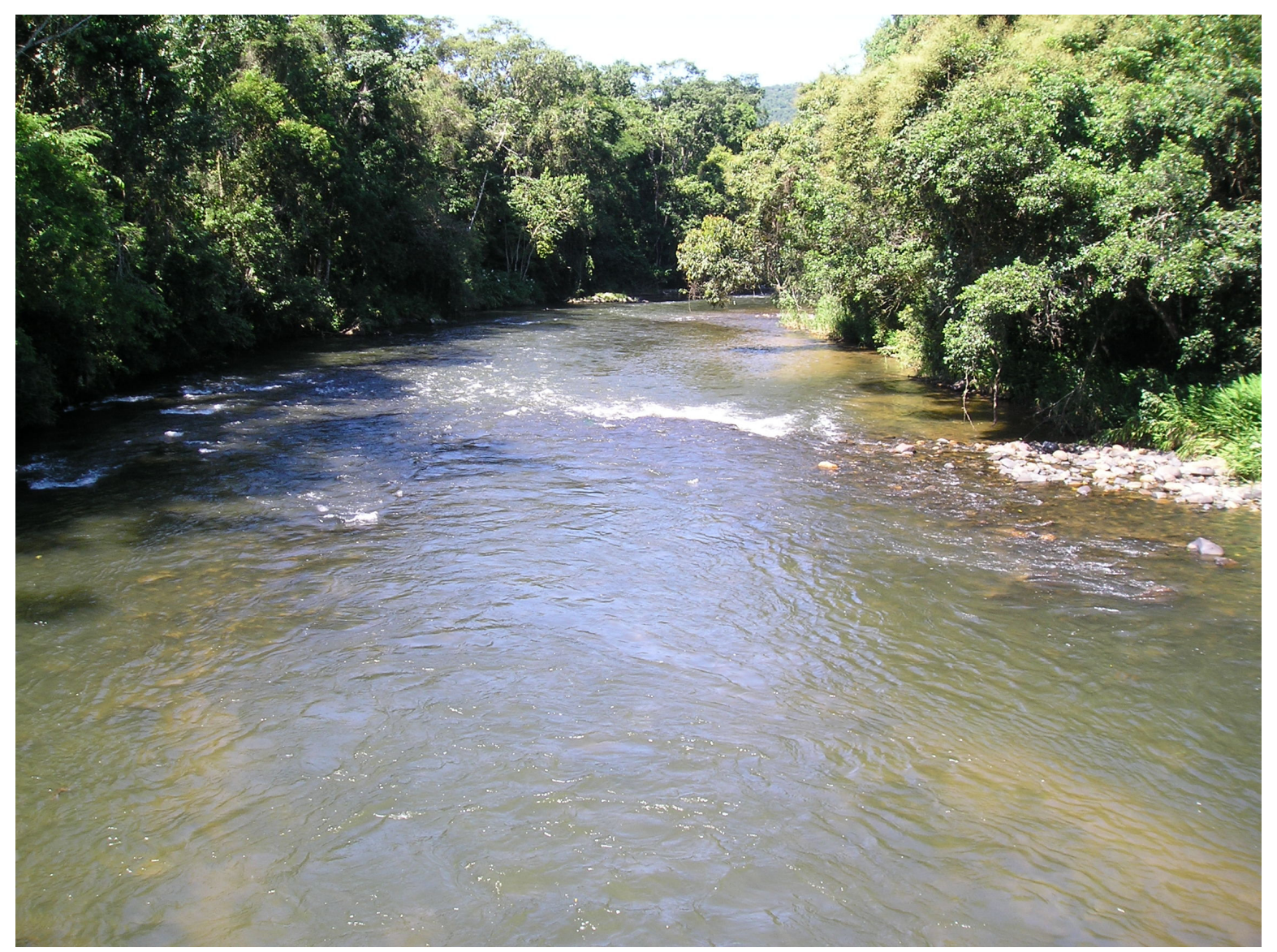

Rio Pilões, 2007. Foto: Tiago Marques de Oliveira. 


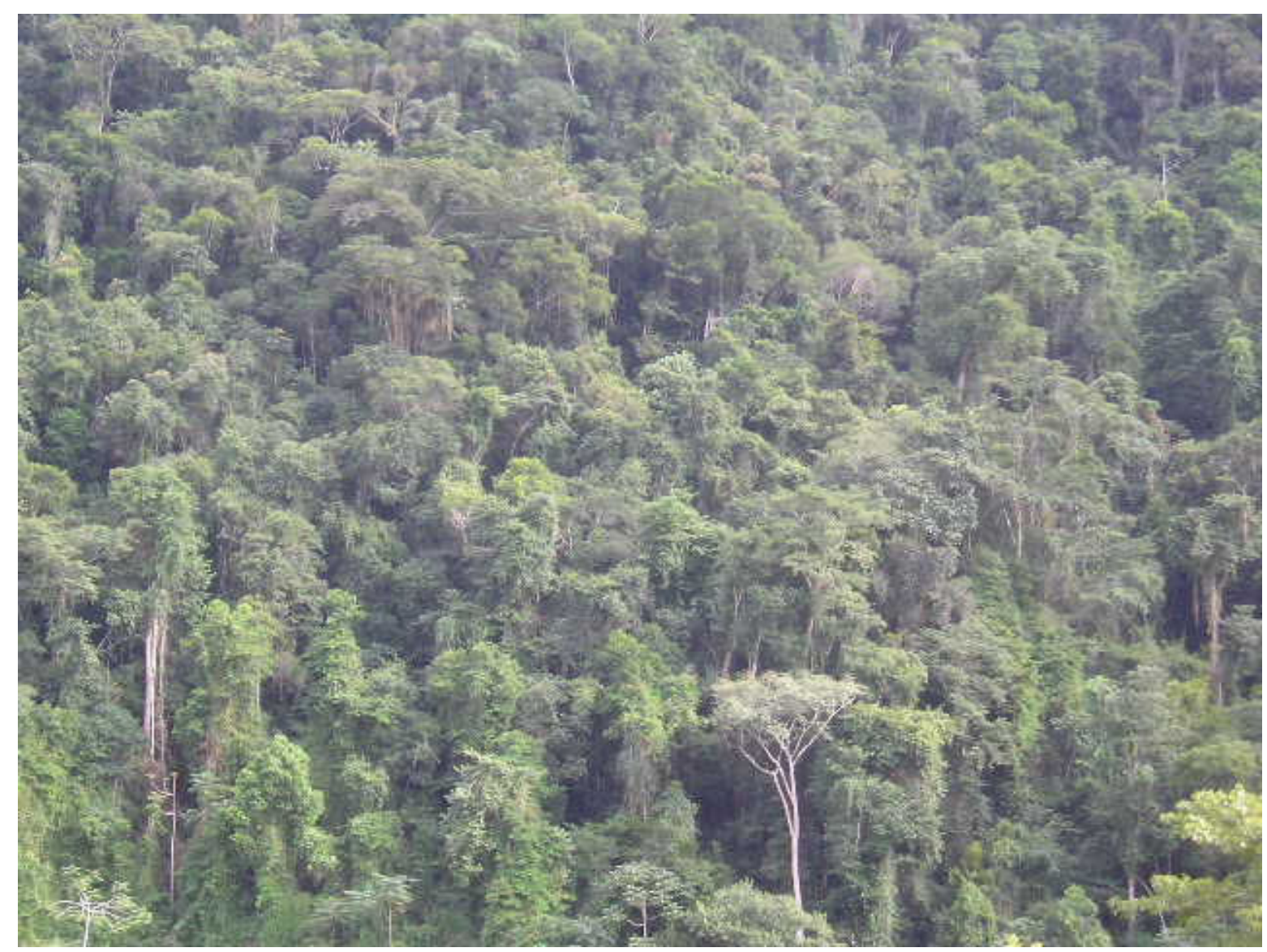

Mata Atlântica, 2007. Arquivo da Fundação ITESP. 


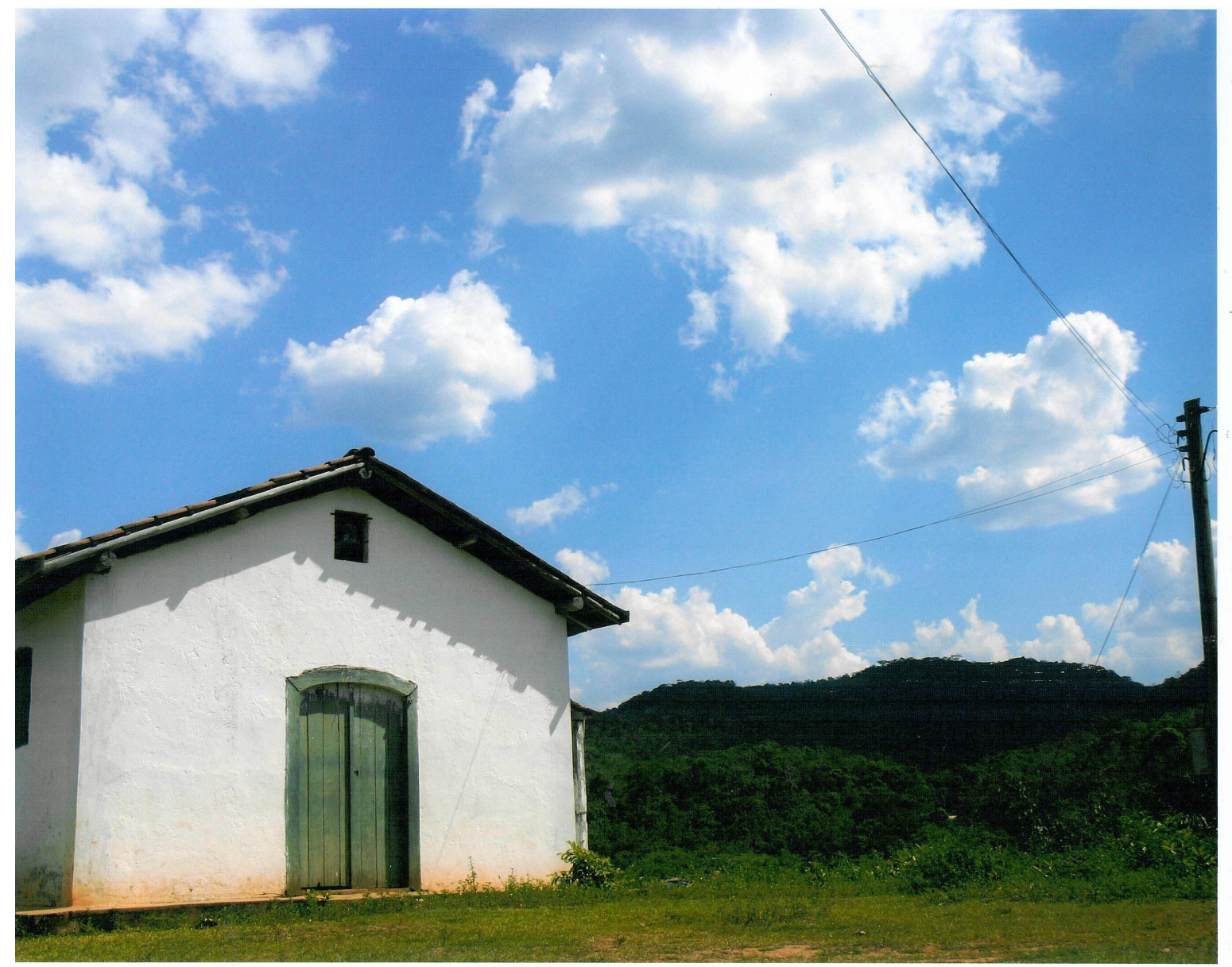

Igreja da Comunidade Remanescente de Quilombo de Pilões, 2007 - Tiago Marques de Oliveira - Arquivo da Fundação ITESP. 


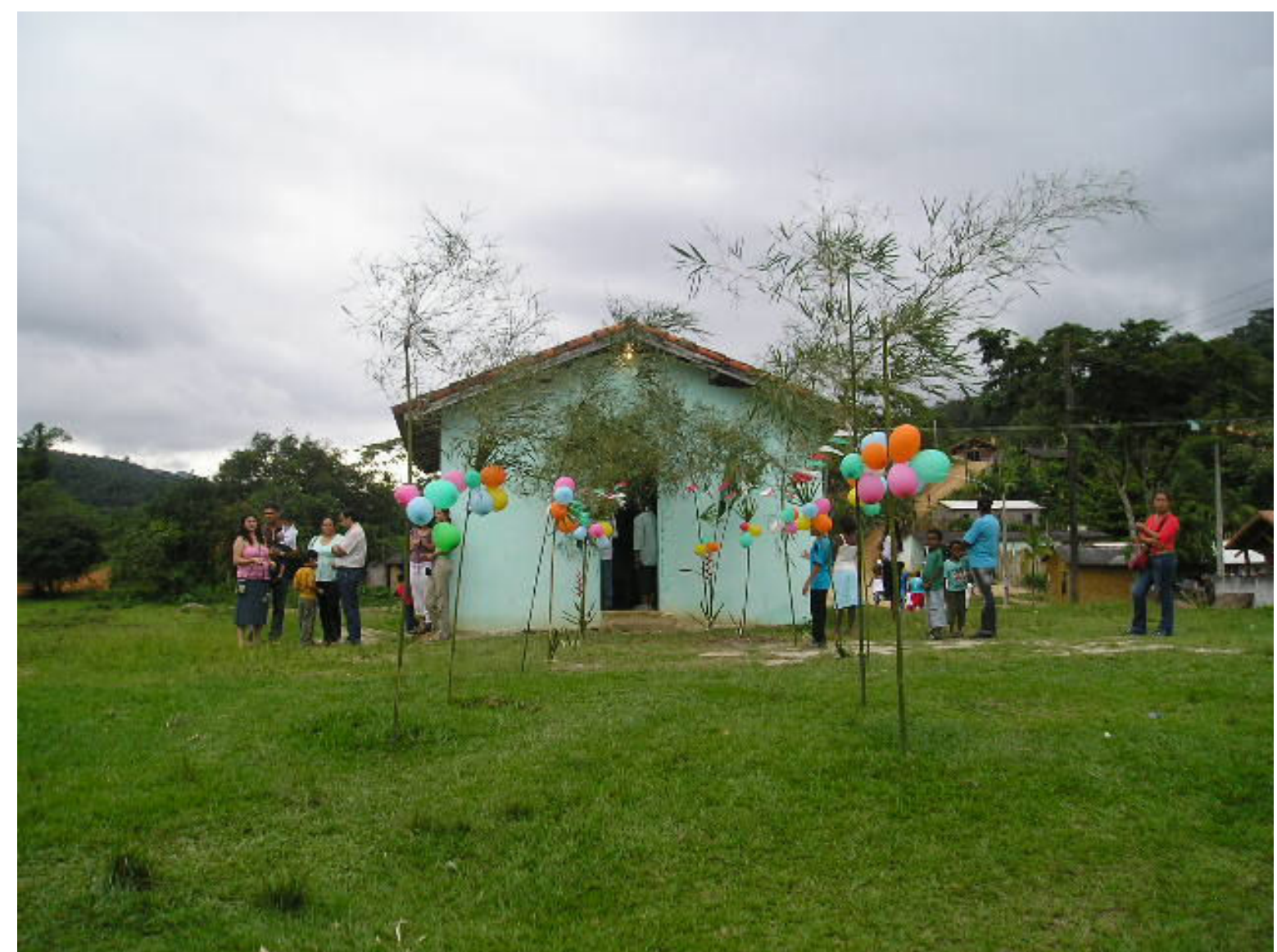

Igreja da Comunidade Remanescente de Quilombo de Pedro Cubas, 2008. Foto: Tiago Marques de Oliveira 


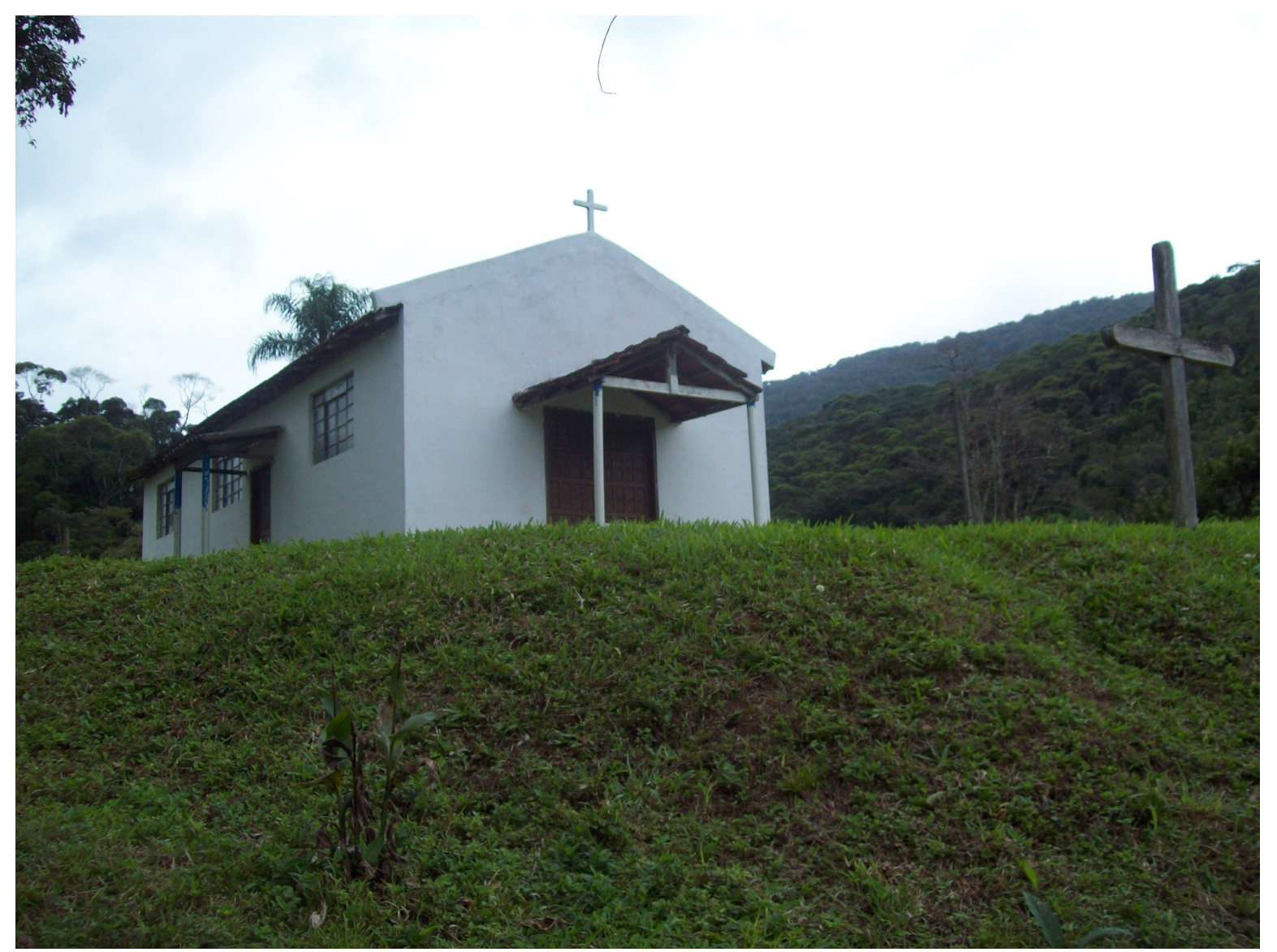

Igreja da Comunidade Remanescente de Quilombo de São Pedro/ Arquivo do ITESP. 


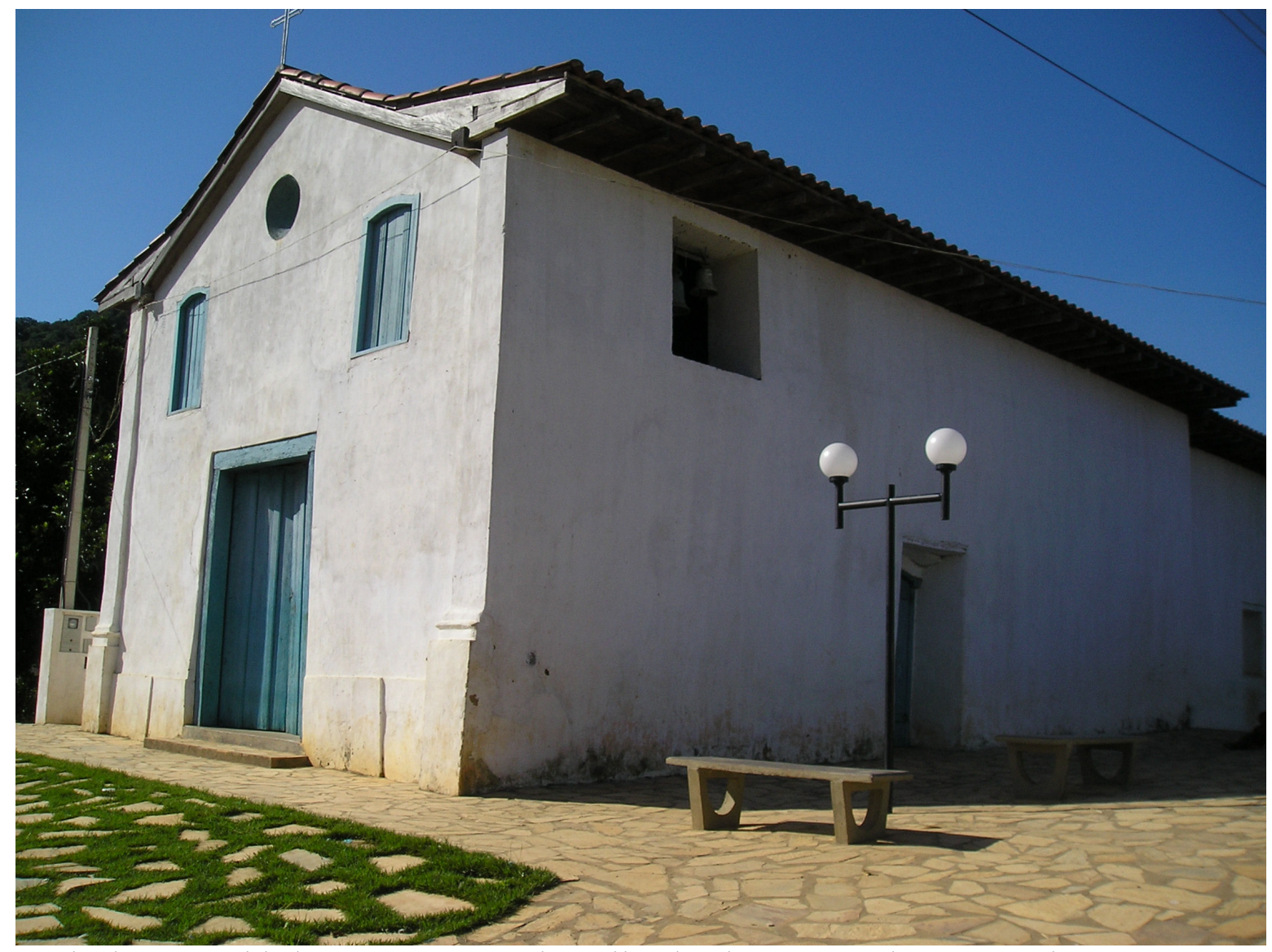

Igreja da Comunidade Remanescente de Quilombo do Ivaporunduva - Arquivo Itesp 


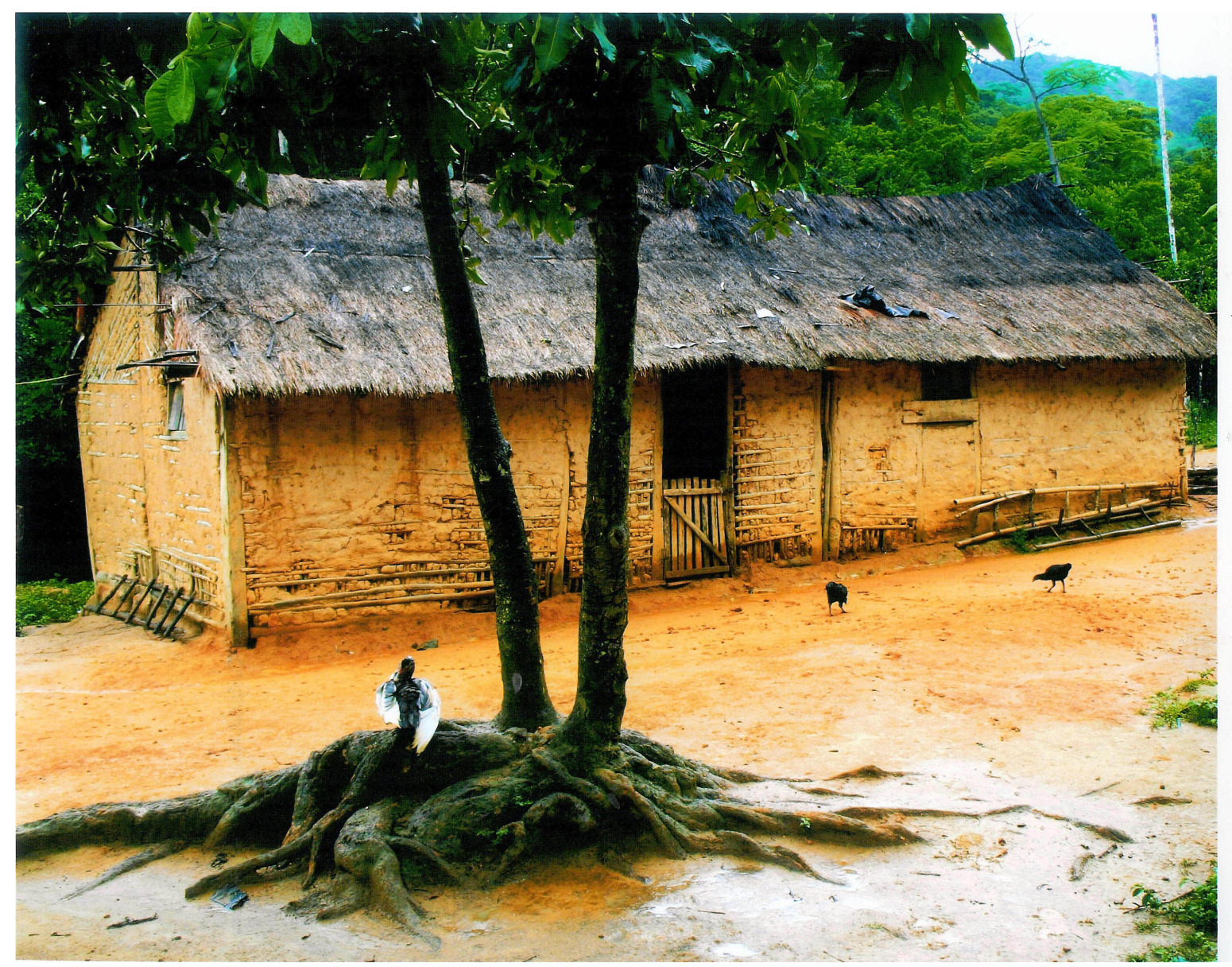

Casa barreada - Foto: Maria das Dores Teixeira. Arquivo do ITESP 


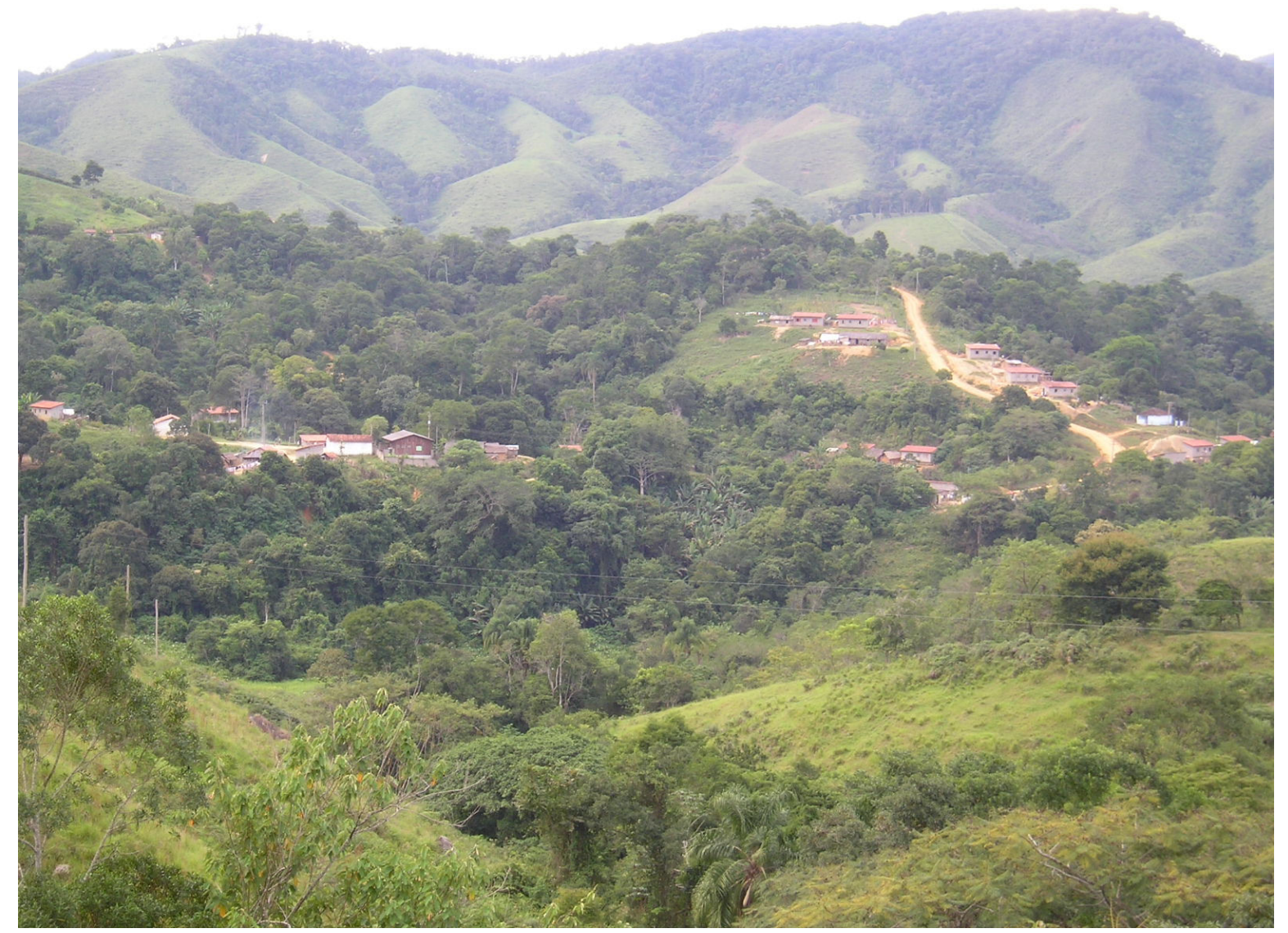

Cangume - Foto: Tiago Marques de Oliveira/ Arquivo da Fundação ITESP. 


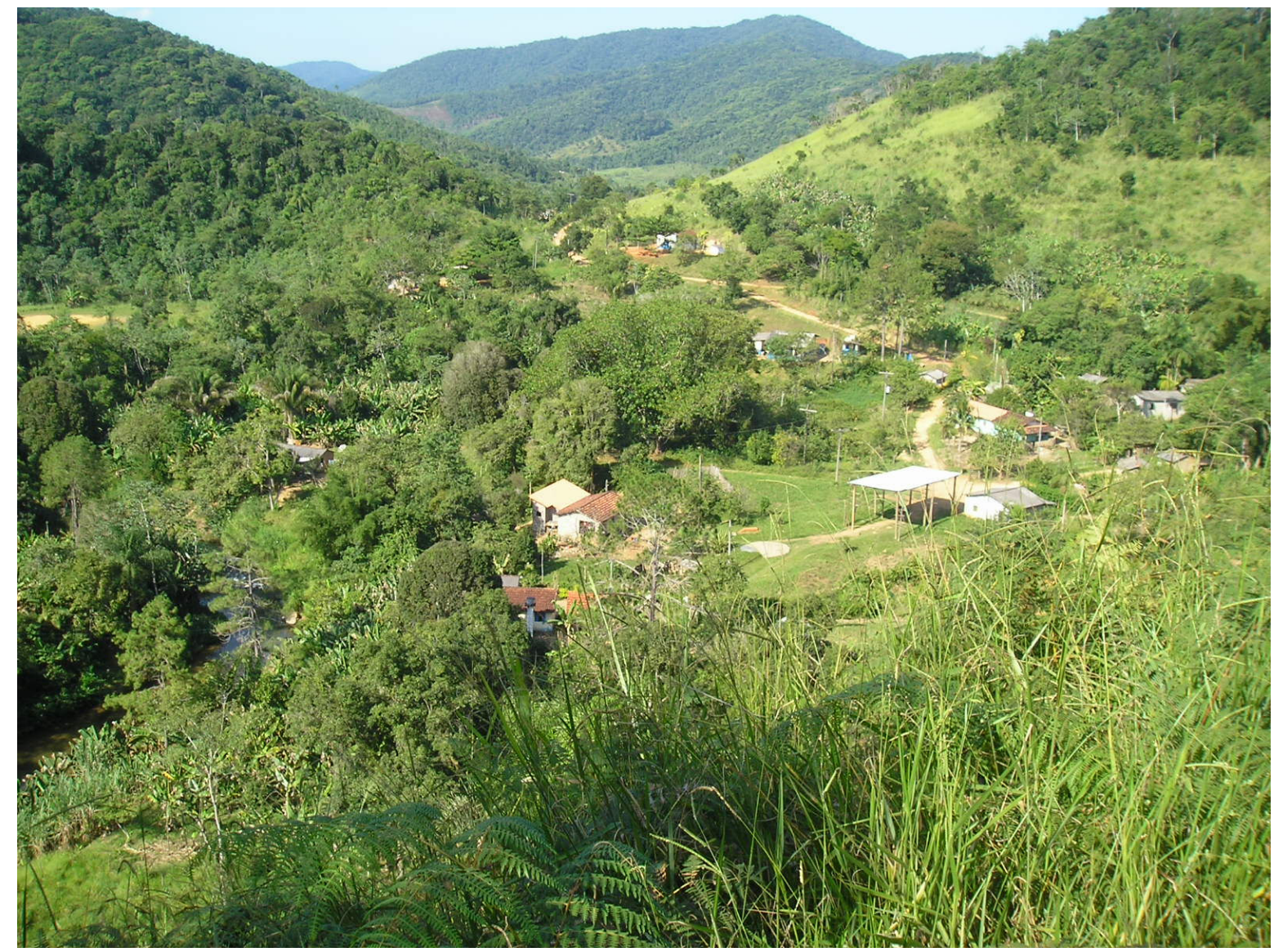

Comunidade Remanescente de Quilombo do Nhunguara, 2007. Foto: Tiago Marques de Oliveira.

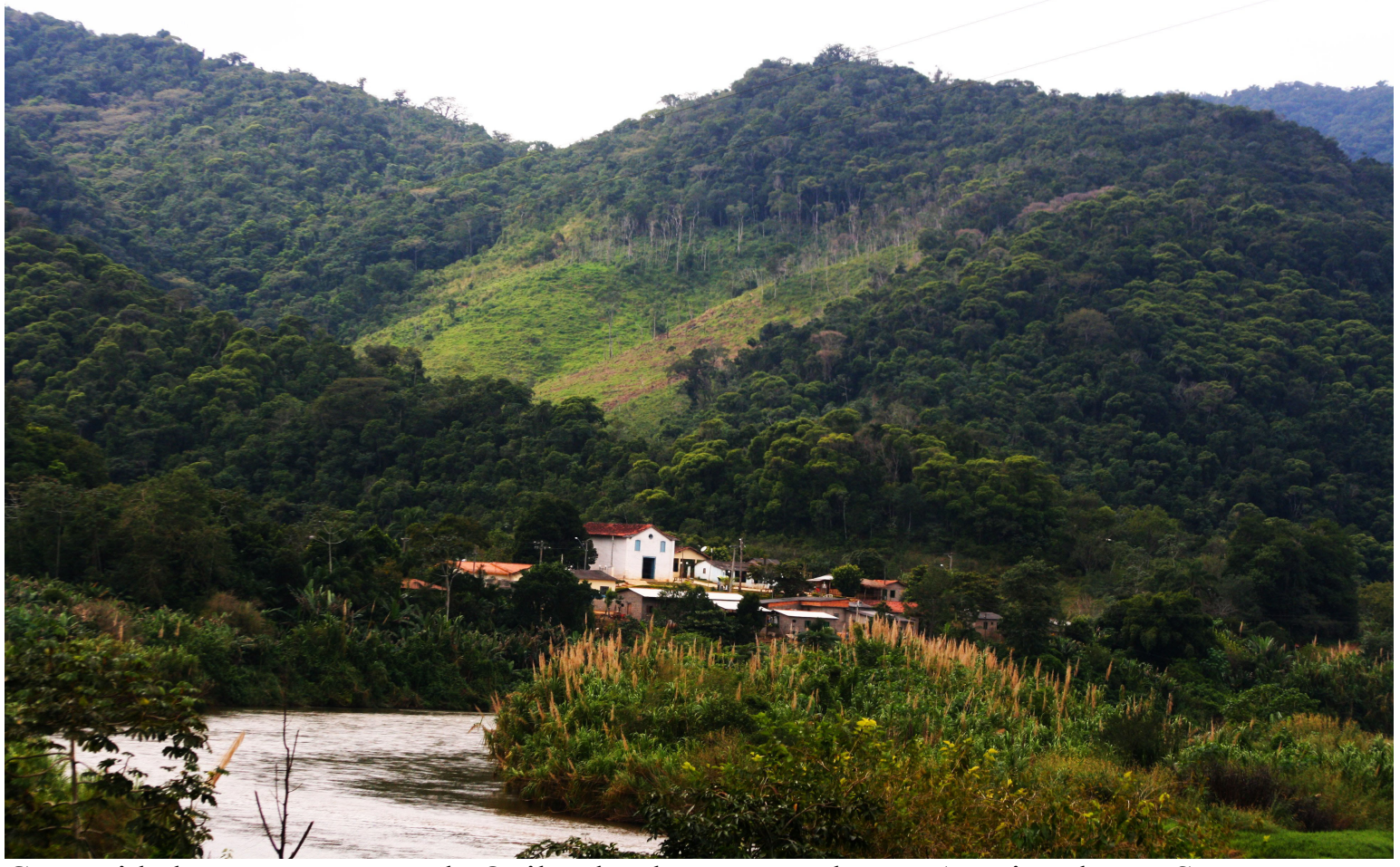

Comunidade Remanescente de Quilombo de Ivaporunduva - Arquivo do ITESP. 


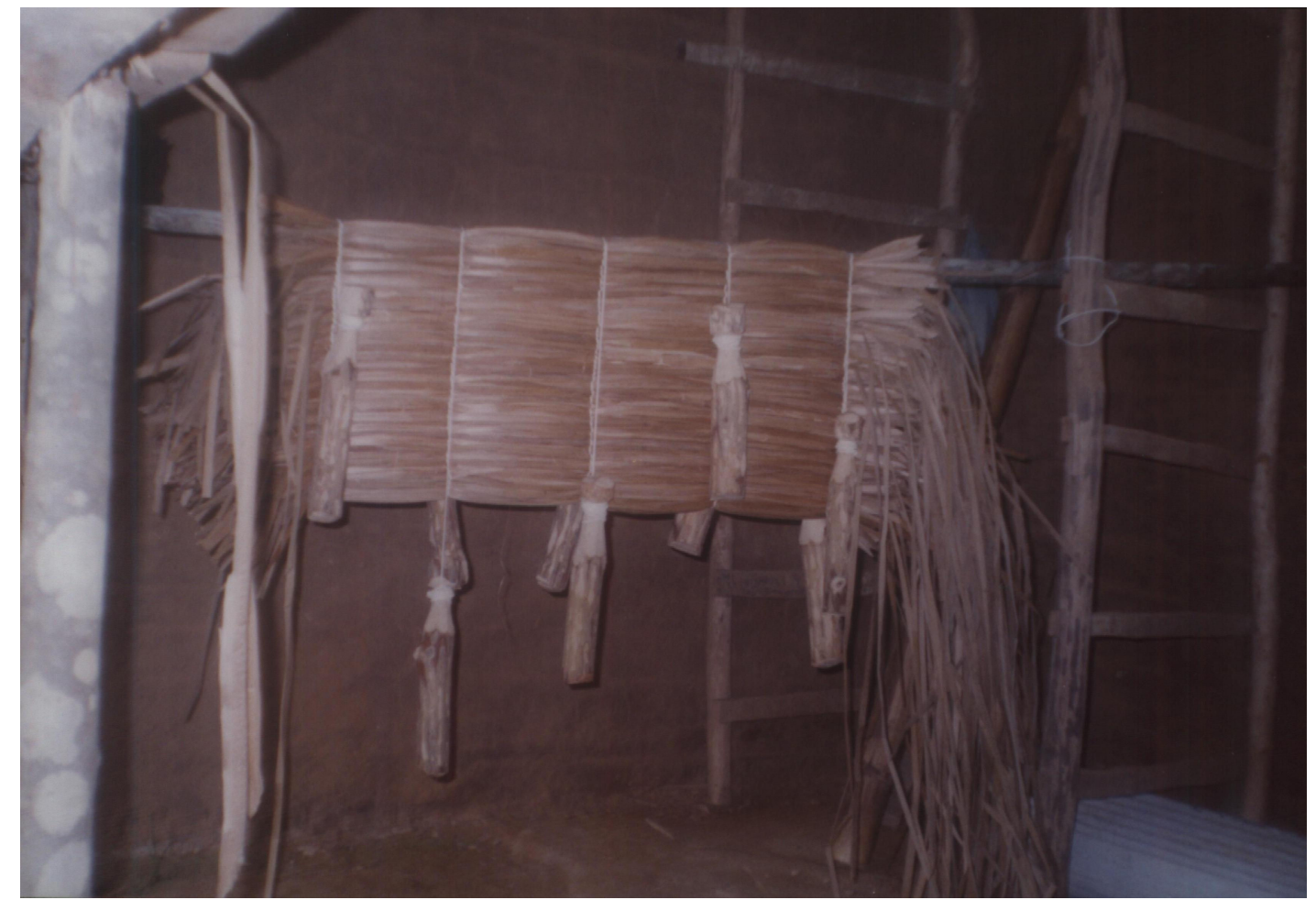

Artesanato (esteira de taboa), Quilombo de Praia Grande, Arquivo do ITESP. 


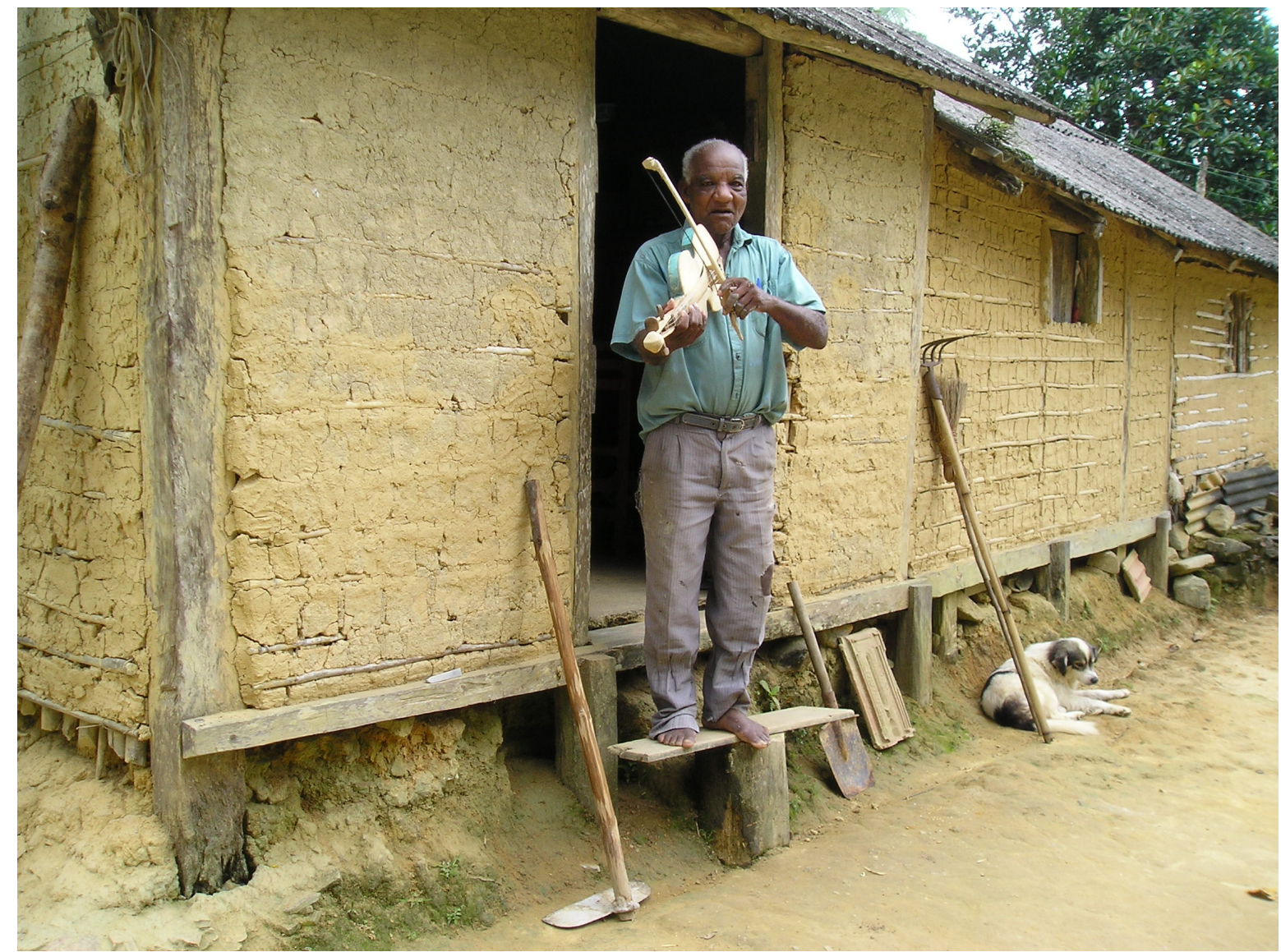

Sr. Bonifácio. Quilombo de Morro Seco - Arquivo da Fundação ITESP.

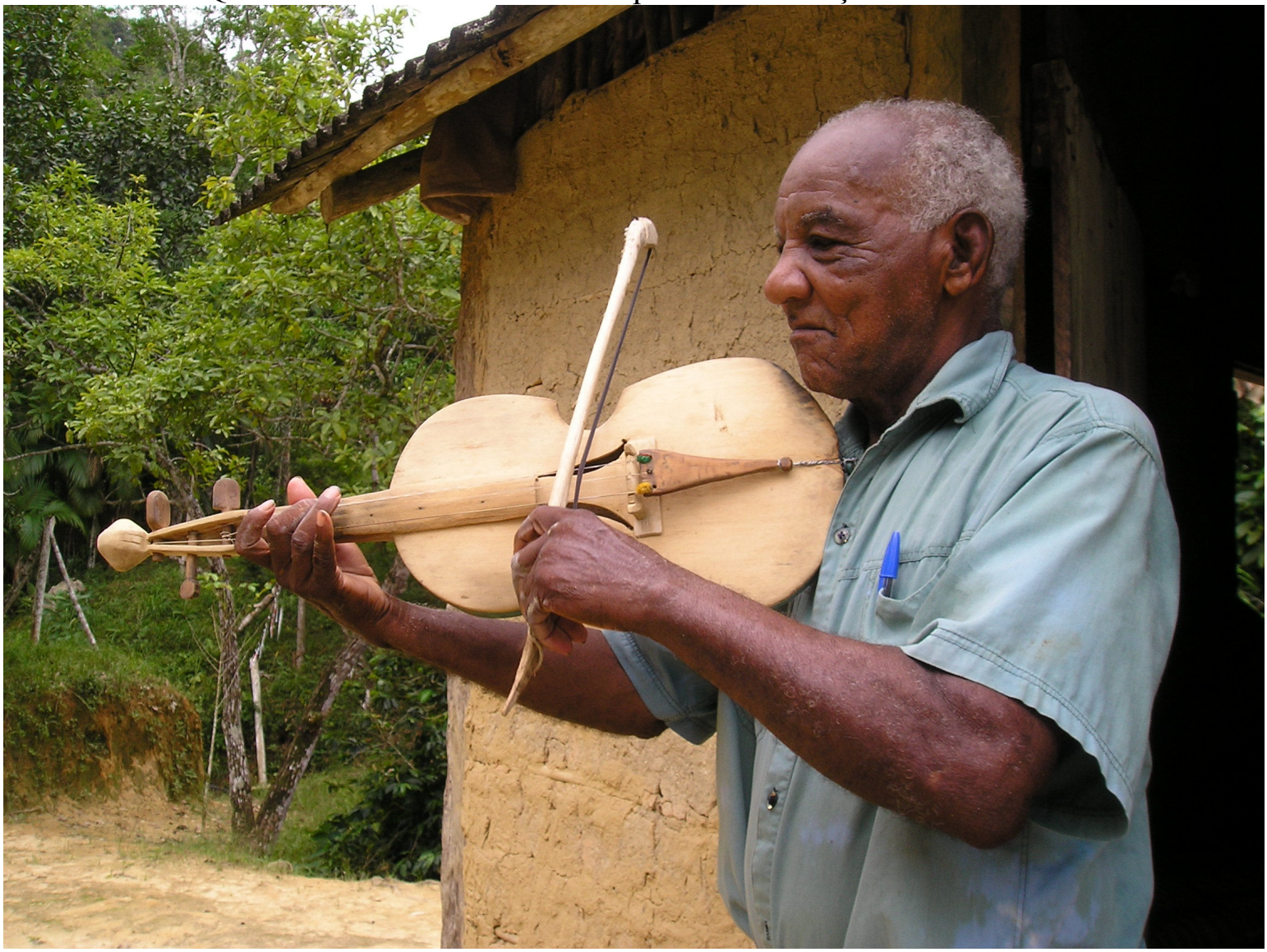

Sr. Bonifácio. Rabeca. Quilombo Morro Seco - Arquivo da Fundação ITESP. 


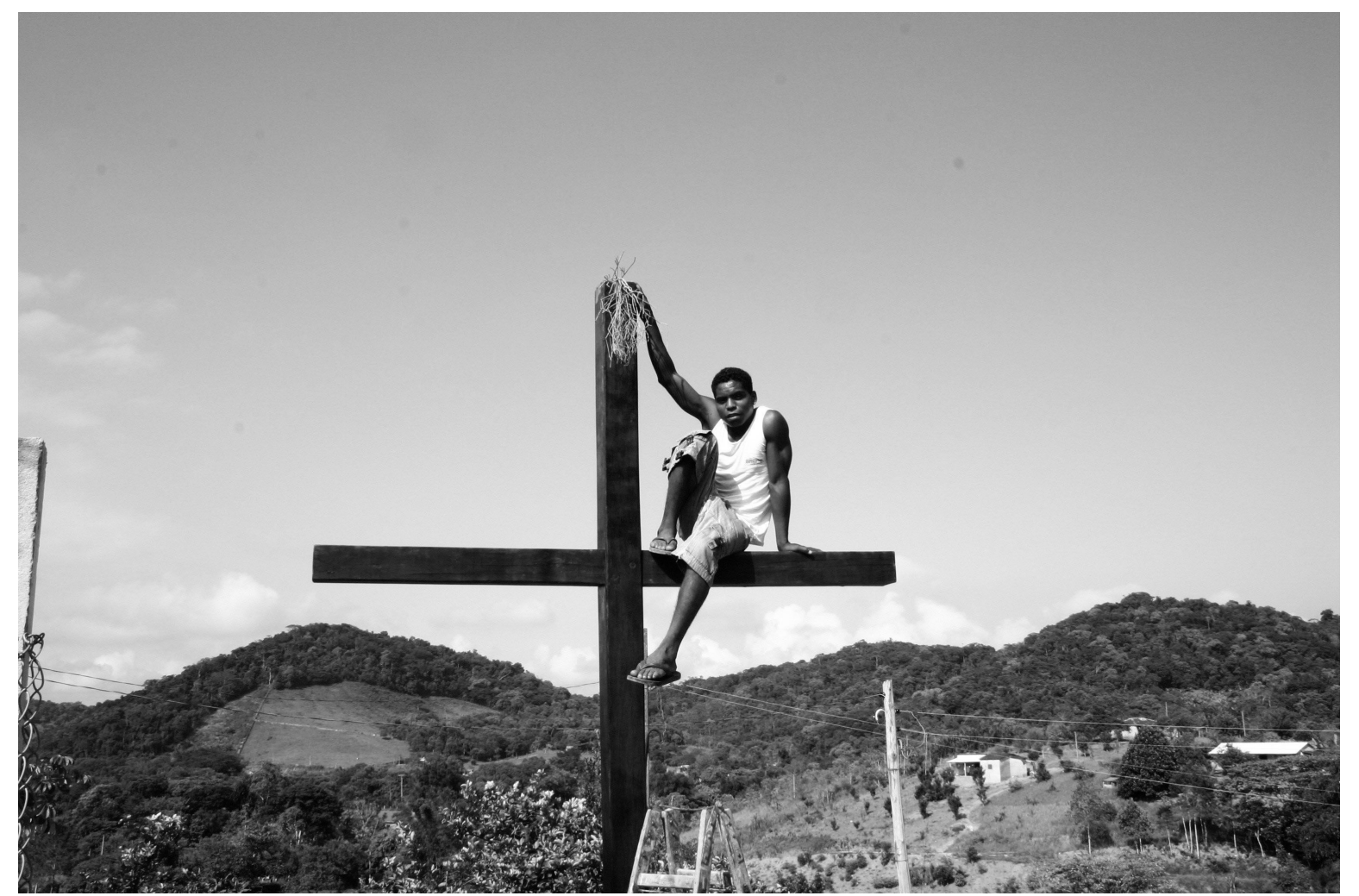

Cruz na Comunidade Remanescente de Quilombo de Morro Seco. Foto: Maria das Dores Teixeira/ Arquivo da Fundação ITESP. 


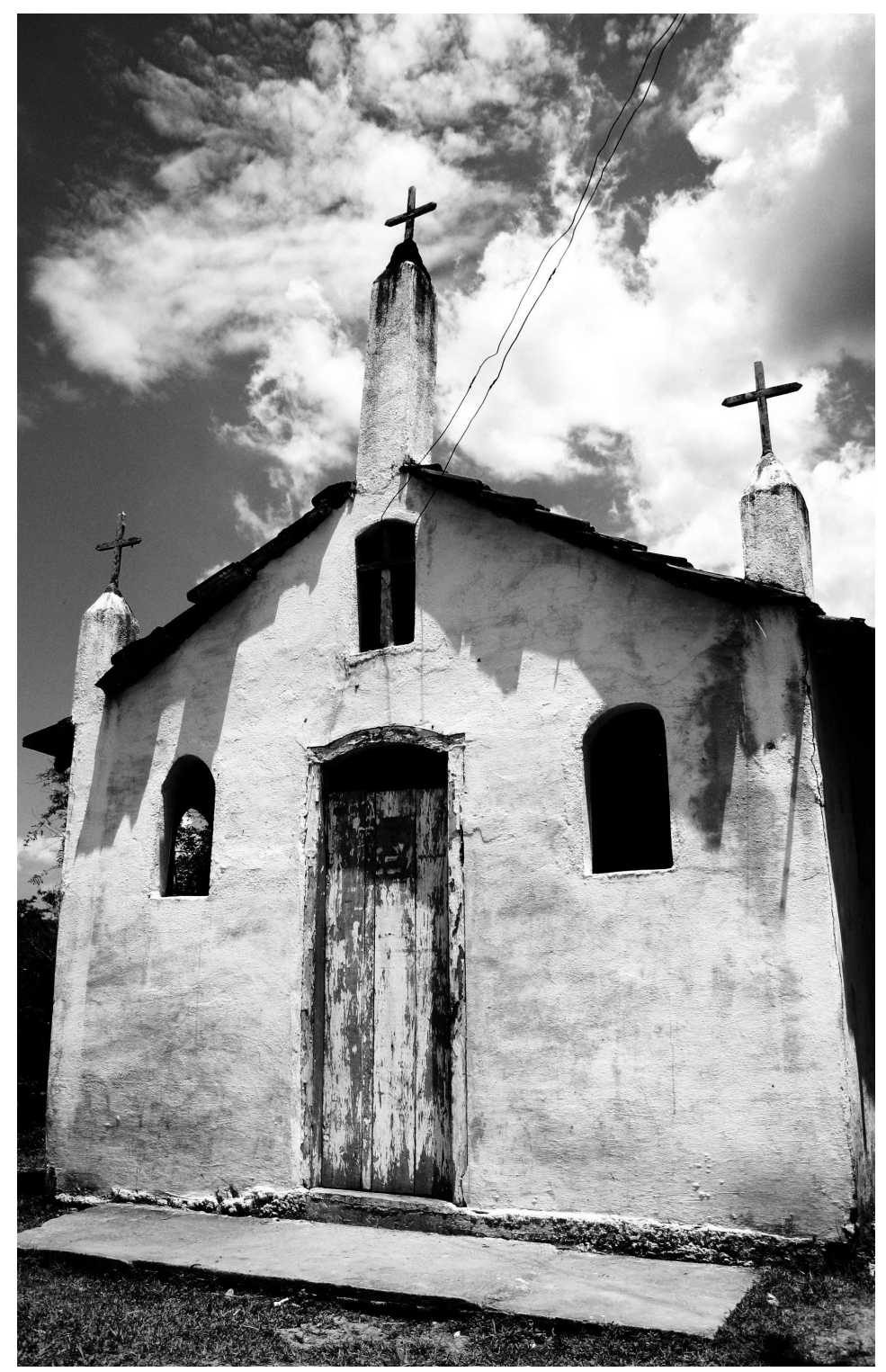

Igreja da Comunidade de Maria Rosa. Foto: Maria das Dores Teixeira. Fundação ITESP. 


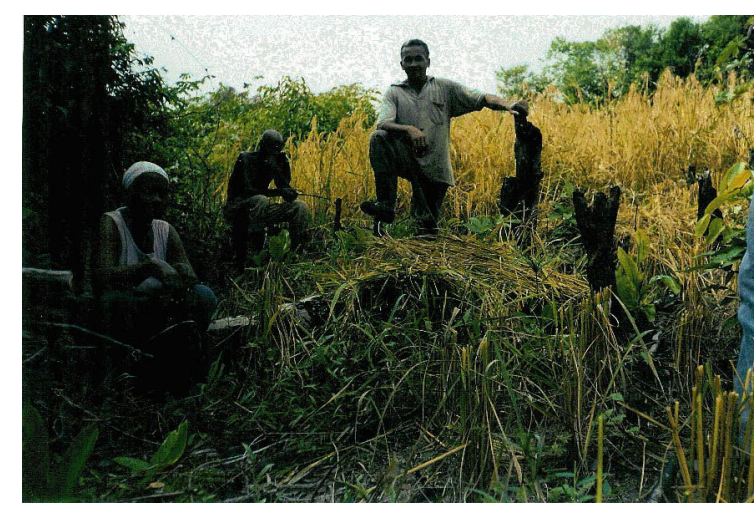

Roça em Pedro Cubas - Arquivo da Fundação ITESP.

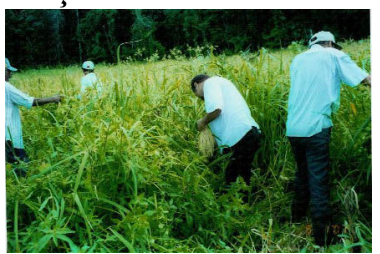

Roça - Arquivo da Fundação ITESP.

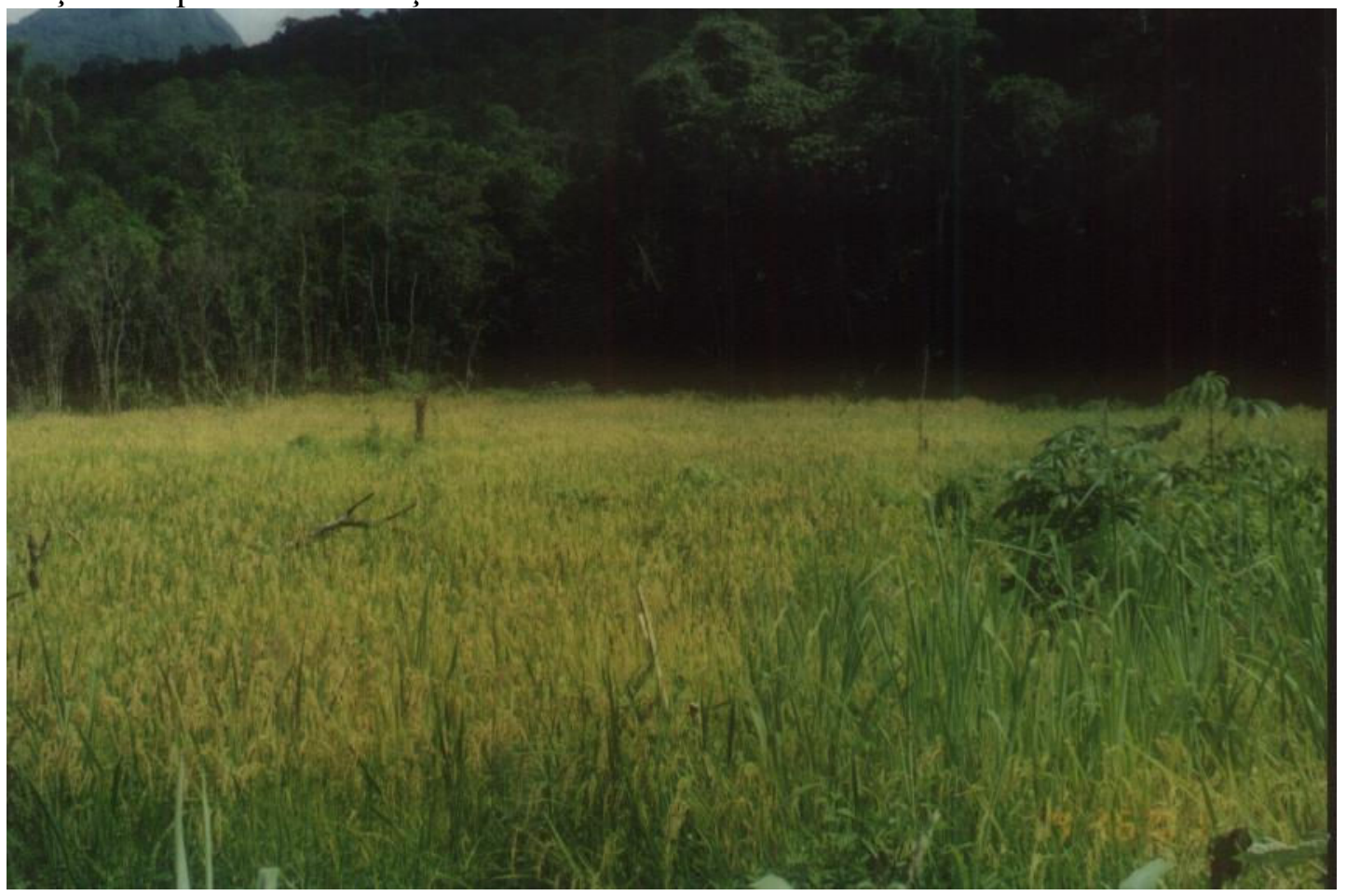

Roça - Arquivo da Fundação ITESP. 


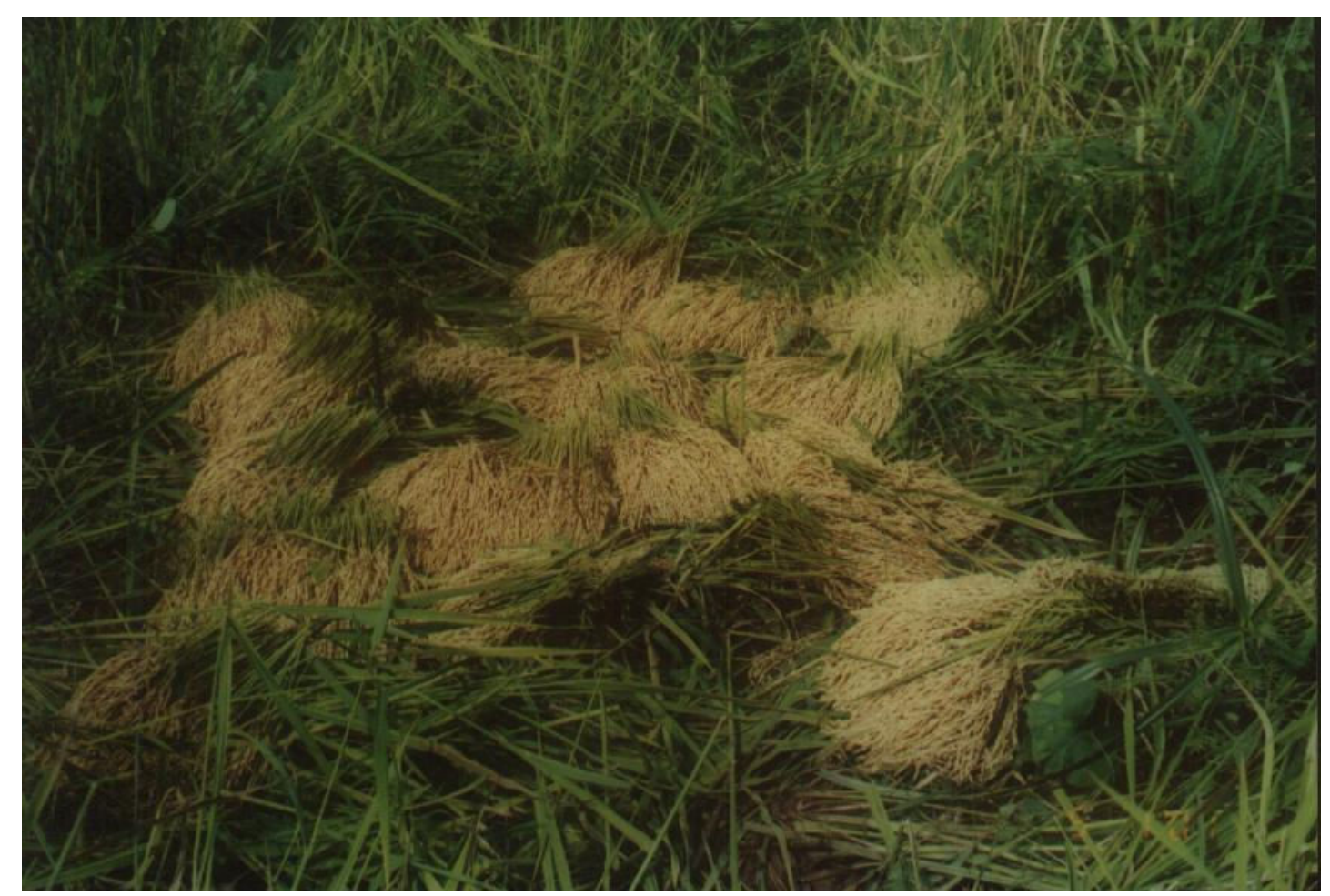

Arroz - Arquivo da Fundação ITESP.

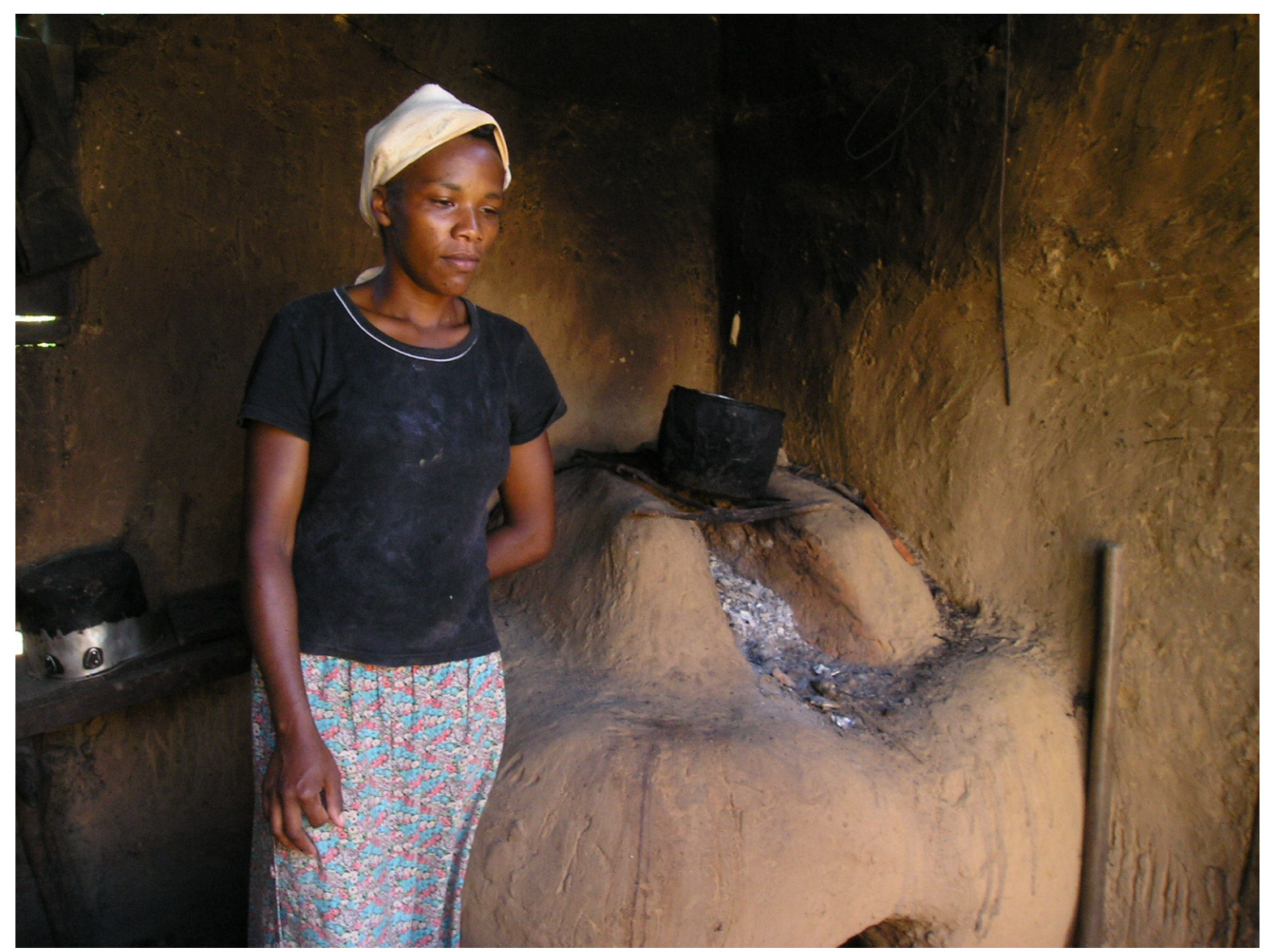

CRQ de Nhunguara - Foto: Maria das Dores Teixeira/ Fundação ITESP. 


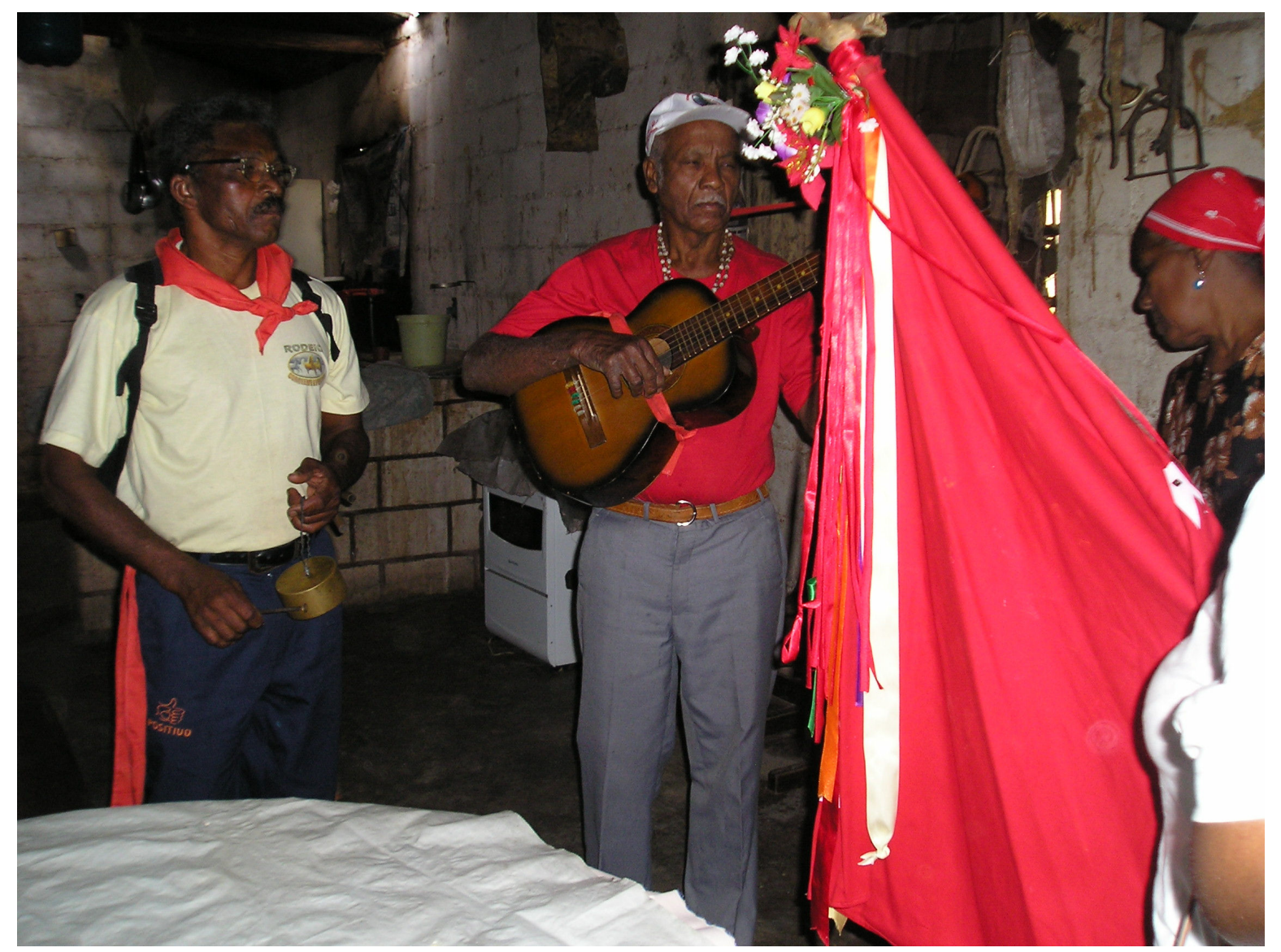

Bandeira do Divino - Quilombo Pedro Cubas. Foto: Gabriela Segarra M. Paes / 2008.

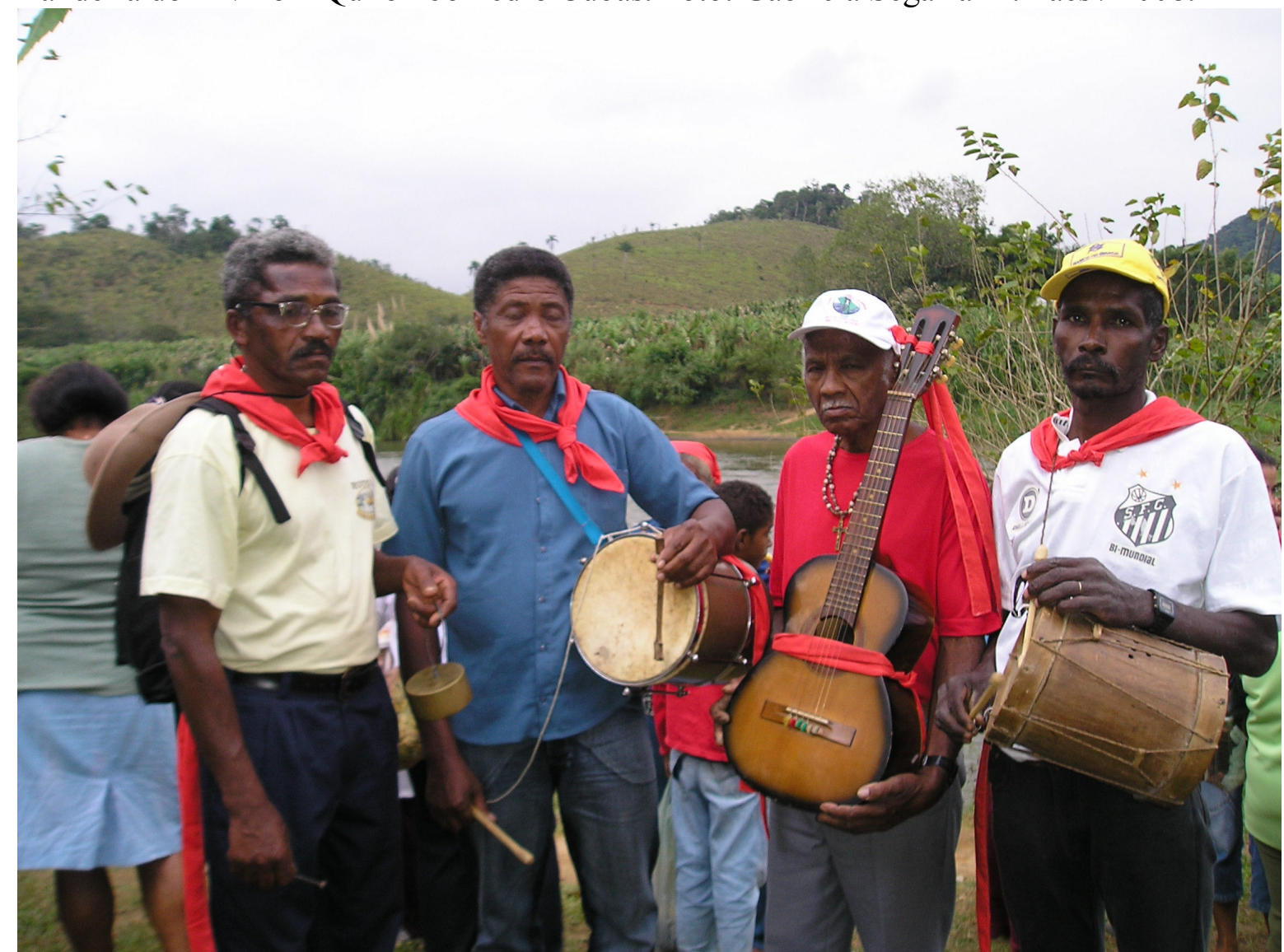

Bandeira do Divino - Quilombolas de Pedro Cubas. Foto: Gabriela Segarra M. Paes / 2008. 


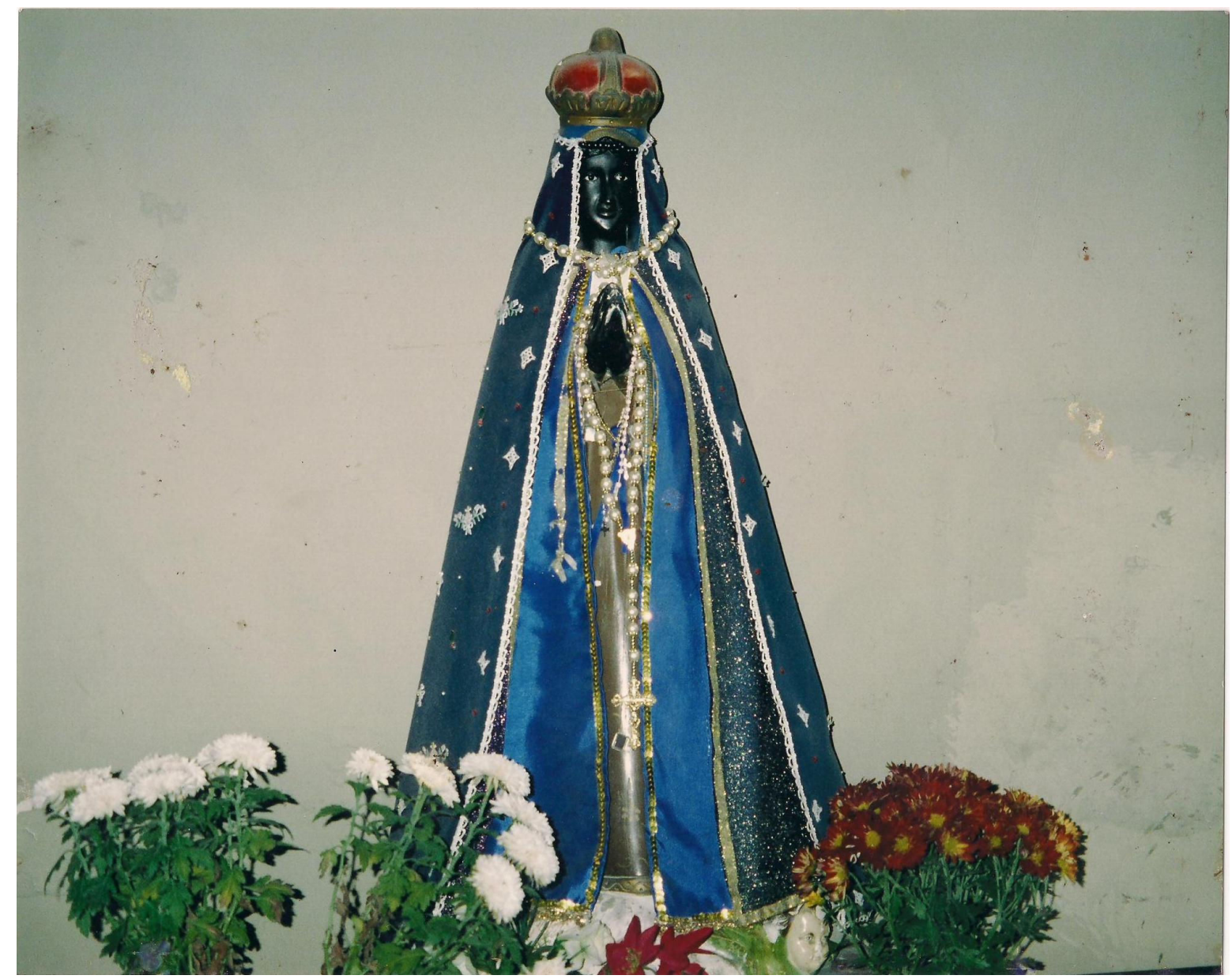

Nossa Senhora do Rosário - Quilombo Ivaporunduva - Arquivo ITESP.

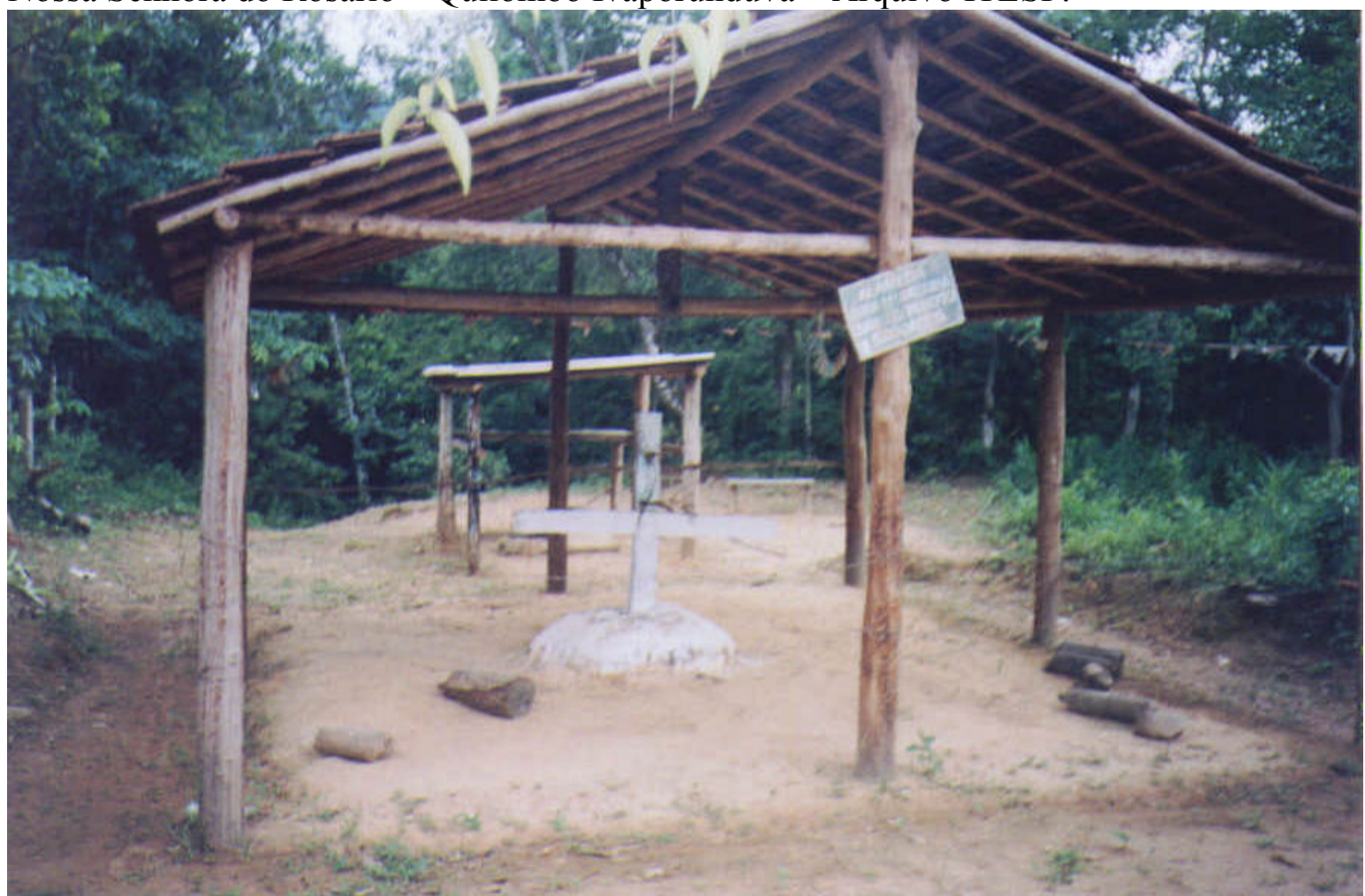

Bica Canhambora, 2001. Foto: Patrícia Scalli dos Santos. 


\section{Iguape}

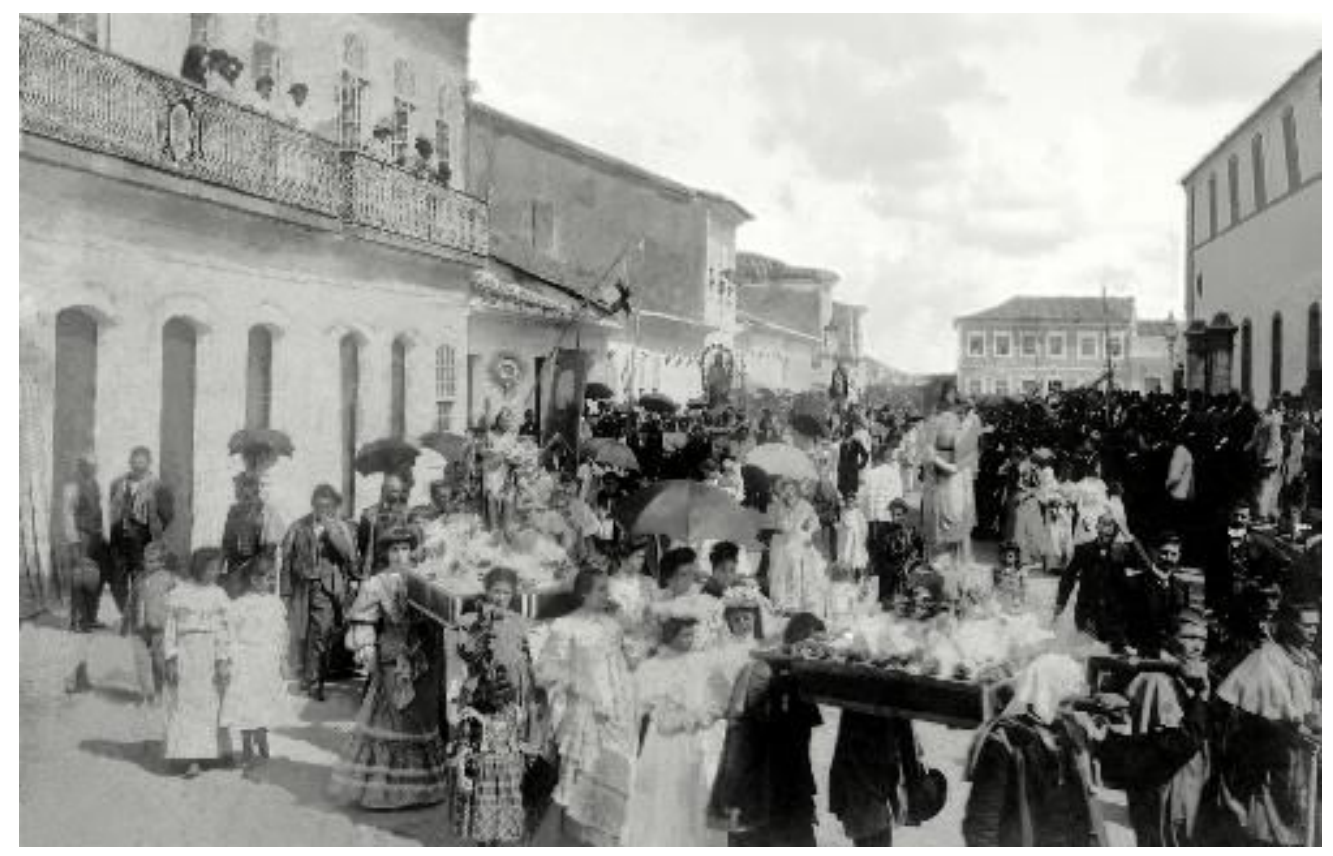

Procissão do Senhor Bom Jesus, 1906. Foto publicada por Roberto Fortes no dia 21 de setembro de 2004 (http://robertofortes.fotoblog.uol.com.br). 


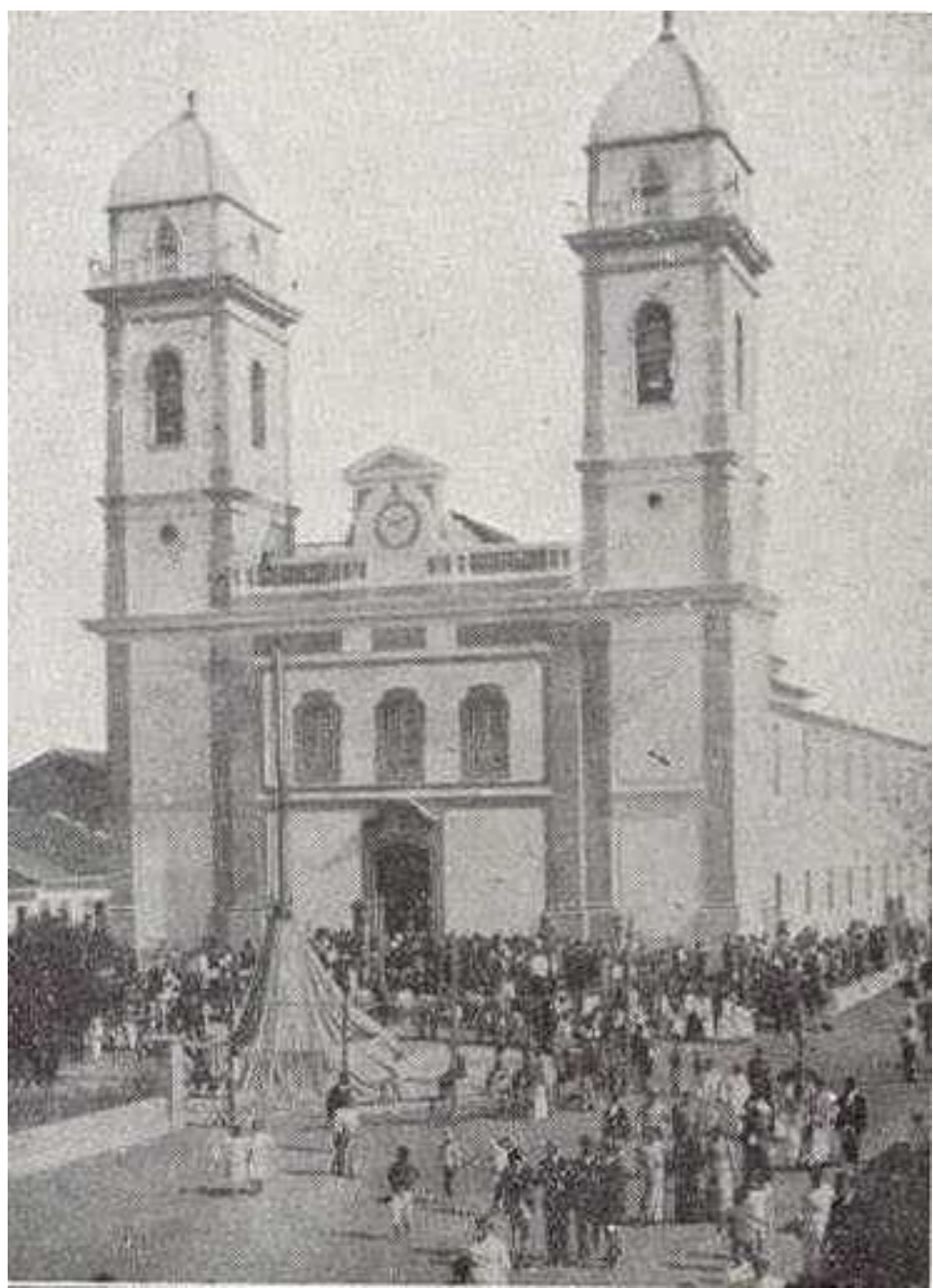

Procissão do Senhor Bom Jesus de Iguape, 1916. Foto publicada na revista "A Cigarra" na edição $n^{\circ} 49(31 / 08 / 1916)$ e também por Roberto Fortes no dia 13 de março de 2008 (http://robertofortes.fotoblog.uol.com). 


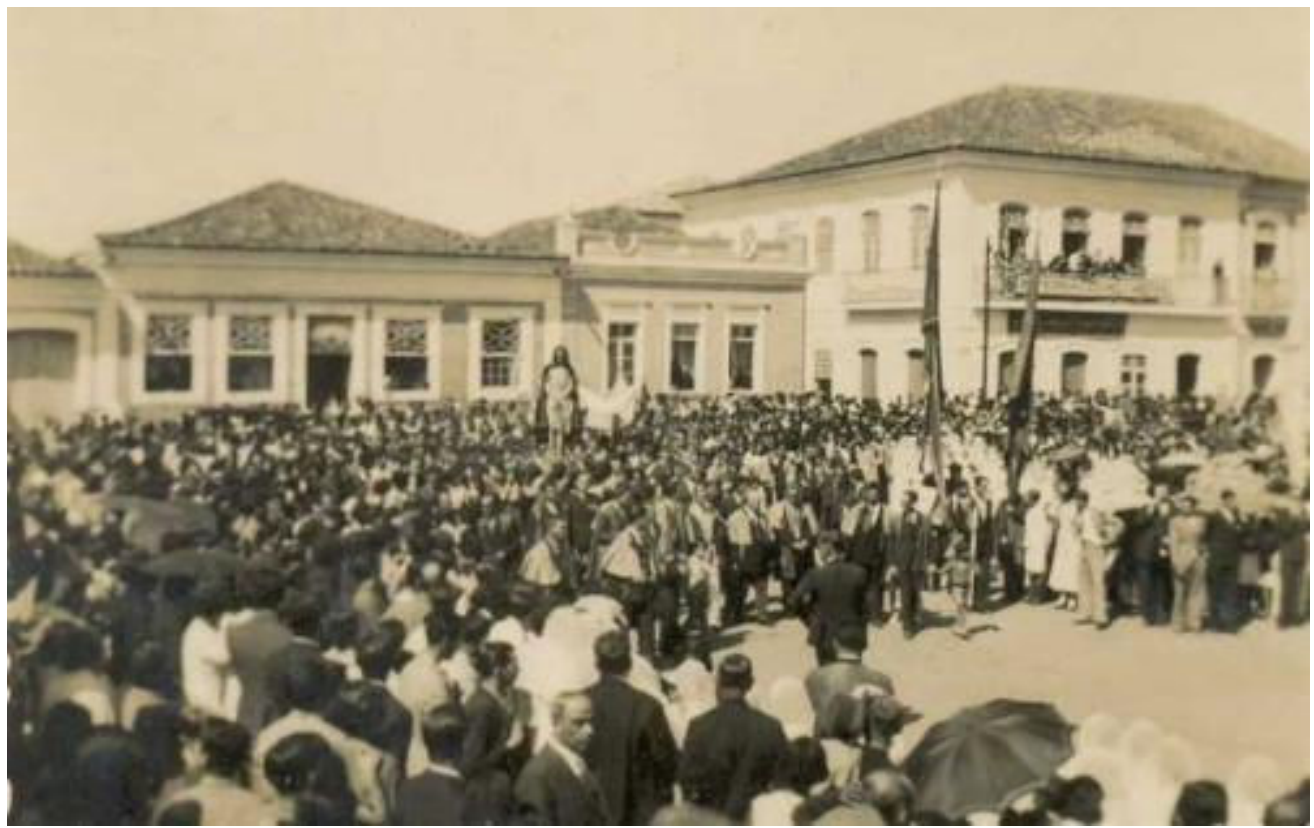

Procissão do Senhor Bom Jesus de Iguape, na década de 1940. Foto publicada por Roberto Fortes (http://robertofortes.fotoblog.uol.com).

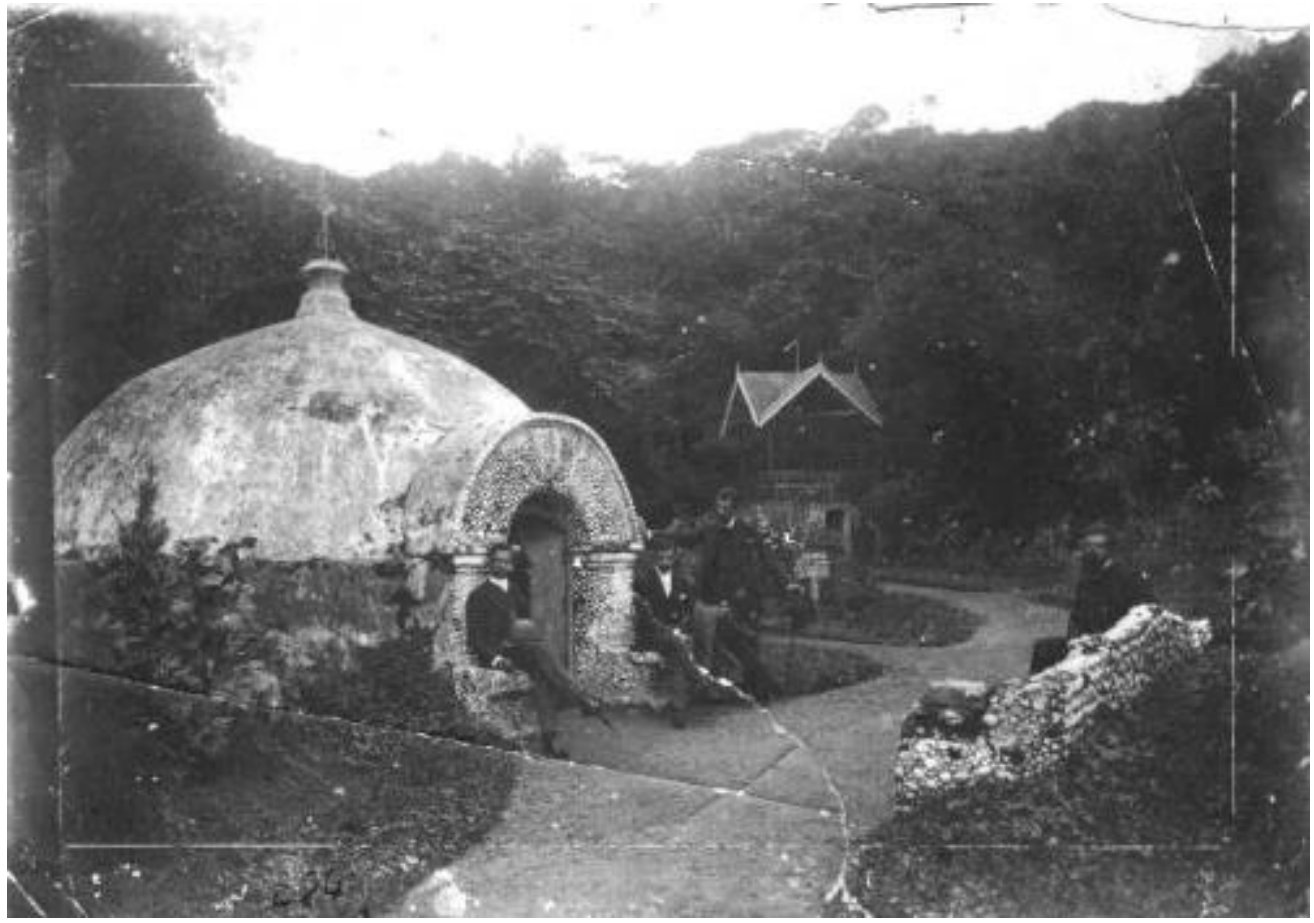

Fonte do Senhor, década de 1920. Foto publicada por Roberto Fortes.

(http://robertofortes.fotoblog.uol.com.br) 


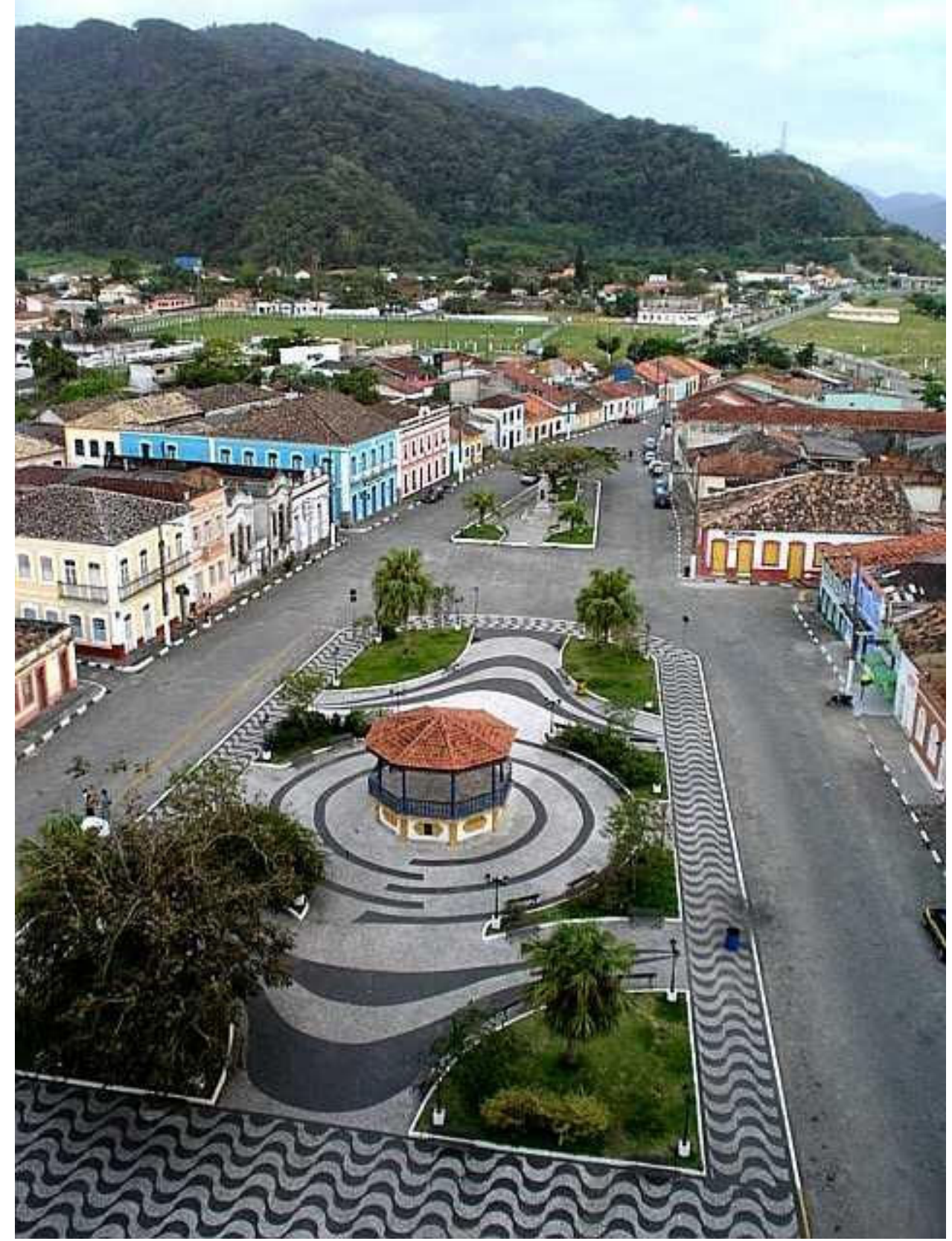

http://robertofortes.fotoblog.uol.com.br/photo20051020212509.html Iguape nos dias de hoje. Foto publicada por Roberto Fortes (http://robertofortes.fotoblog.uol.com.br) 